

\title{
Witchcraft,
}

Demonology

and Magic

Edited by

Marina Montesano

Printed Edition of the Special Issue Published in Religions 
Witchcraft, Demonology and Magic 



\section{Witchcraft, Demonology and Magic}

Special Issue Editor

Marina Montesano

MDPI • Basel • Beijing • Wuhan • Barcelona • Belgrade

\section{MDPI}


Special Issue Editor

Marina Montesano

Department of Ancient and

Modern Civilizations, Università

degli Studi di Messina

Italy

\section{Editorial Office}

MDPI

St. Alban-Anlage 66

4052 Basel, Switzerland

This is a reprint of articles from the Special Issue published online in the open access journal Religions (ISSN 2077-1444) from 2019 to 2020 (available at: https: / / www.mdpi.com/journal/religions / special_ issues/witchcraft).

For citation purposes, cite each article independently as indicated on the article page online and as indicated below:

LastName, A.A.; LastName, B.B.; LastName, C.C. Article Title. Journal Name Year, Article Number, Page Range.

ISBN 978-3-03928-959-2 (Pbk)

ISBN 978-3-03928-960-8 (PDF)

(c) 2020 by the authors. Articles in this book are Open Access and distributed under the Creative Commons Attribution (CC BY) license, which allows users to download, copy and build upon published articles, as long as the author and publisher are properly credited, which ensures maximum dissemination and a wider impact of our publications.

The book as a whole is distributed by MDPI under the terms and conditions of the Creative Commons license CC BY-NC-ND. 


\section{Contents}

About the Special Issue Editor $\ldots \ldots \ldots \ldots \ldots \ldots \ldots \ldots$ vii

\section{Marina Montesano}

Introduction to the Special Issue: Witchcraft, Demonology and Magic

Reprinted from: Religions 2020, 11, 187, doi:10.3390/rel11040187 . . . . . . . . . . . . . . 1

\section{Fabiana Ambrosi}

Giovan Battista Codronchi's De morbis Veneficis ac Veneficiis (1595). Medicine, Exorcism and Inquisition in Counter-Reformation Italy

Reprinted from: Religions 2019, 10, 612, doi:10.3390/rel10110612 . . . . . . . . . . . . . 4

\section{Fabrizio Conti}

Notes on the Nature of Beliefs in Witchcraft: Folklore and Classical Culture in Fifteenth Century Mendicant Traditions

Reprinted from: Religions 2019, 10, 576, doi:10.3390/rel10100576 . . . . . . . . . . . . . . 20

\section{Ismael del Olmo}

"Such Fictitious Evil Spirits": Adriaan Koerbagh's Rejection of Biblical Demons and Demonic Possession in A Light Shining in Dark Places (1668)

Reprinted from: Religions 2019, 10, 280, doi:10.3390/rel10040280 . . . . . . . . . . . . . . 3

\section{Ildiko Sz. Kristof}

"Charming Sorcerers" or "Soldiers of Satan"? Witchcraft and Magic in the Eyes of Protestant/Calvinist Preachers in Early Modern Hungary ${ }^{\dagger}$

Reprinted from: Religions 2019, 10, 328, doi:10.3390/rel10050328 . . . . . . . . . . . . . . . .

\section{Debora Moretti}

Angels or Demons? Interactions and Borrowings between Folk Traditions, Religion and Demonology in Early Modern Italian Witchcraft Trials

Reprinted from: Religions 2019, 10, 326, doi:10.3390/rel10050326 . . . . . . . . . . . . . . . .

\section{Helen Parish}

"Paltrie Vermin, Cats, Mise, Toads, and Weasils": Witches, Familiars, and Human-Animal Interactions in the English Witch Trials

Reprinted from: Religions 2019, 10, 134, doi:10.3390/rel10020134 . . . . . . . . . . . . .

\section{Vincenzo Tedesco}

Treasure Hunt-Roman Inquisition and Magical Practices Ad Inveniendos Thesauros in Southern Tuscany

Reprinted from: Religions 2019, 10, 444, doi:10.3390/rel10070444 . . . . . . . . . . . . . . 98

\section{Rita Voltmer}

Debating the Devil's Clergy. Demonology and the Media in Dialogue with Trials (14th to 17th Century)

Reprinted from: Religions $2019,10,648$, doi:10.3390/rel10120648 _ . . . . . . . . . . . . . 109

\section{Francis Young}

The Dissolution of the Monasteries and the Democratisation of Magic in Post-Reformation England

Reprinted from: Religions 2019, 10, 241, doi:10.3390/rel10040241 . . . . . . . . . . . . . . 141 



\section{About the Special Issue Editor}

Marina Montesano is full professor of Medieval History at the University of Messina, Italy. She obtained a PhD in Medieval History from the University of Florence and has been a visiting scholar at the Centre d'Études Supérieurs de Civilisation Médiévale in Poitiers and at Brown University in Providence, RI, and has obtained fellowships at the Accademia della Crusca (Florence) and Villa I Tatti, The Harvard University Center for Italian Renaissance Studies in Florence. She is a member of the Association pour le Développement de l'Histoire Culturelle (ADHC) and, since September 2018, member of the Committee of the International Society for Cultural History (ISCH). Among her publications: Classical Culture and Witchcraft in Medieval and Renaissance Italy, London, Palgrave/MacMillan, 2018. 



\title{
Editorial \\ Introduction to the Special Issue: Witchcraft, Demonology and Magic
}

\author{
Marina Montesano \\ Department of Ancient and Modern Civilizations, Università degli Studi di Messina, 98168 Messina, Italy; \\ marina.montesano@unime.it
}

Received: 2 March 2020; Accepted: 3 April 2020; Published: 14 April 2020

Witchcraft and magic are topics of enduring interest for many reasons. Chief among these is their extraordinary interdisciplinarity: anthropologists, folklorists, historians, and more have contributed to build a body of work of extreme variety and consistence. Of course, this also means that the subjects themselves are not easy to assess. In a very general way, we can define witchcraft as a supernatural means to cause harm, death, or misfortune, while magic also belongs to the field of the supernatural, or at least esoteric knowledge, but can be used to less dangerous effects: such as for divination and astrology. In Western civilization, however, the witch hunt of Late Medieval-Early Modern times has set a very peculiar perspective in which diabolical witchcraft, the invention of the Sabbat and the persecution of many thousands of (mostly) female and (sometimes) male presumed witches, gave way to a phenomenon that is fundamentally different from traditional witchcraft, even if many case studies conducted in South America or Africa present similarities, especially in contemporary times (see Wachtel 1992; Geschiere 1997). Another peculiarity of magic and witchcraft in Western civilization is given by the number of writings that detailed their nature, techniques, and effects: these include technical treatises about how to perform magic, such as in the case of necromancy (see Kieckhefer 1998; Gal et al. 2017), or the many writings explaining the powers of witches from the point of view of judges and inquisitors.

Today, scholars generally agree on the so-called "cumulative concept of Western witchcraft", meaning that, if there is one thing of which recent scholarship about witch hunting has assured us, it is that all mono-causality theories must be ruled out, as so many factors have been discovered and investigated: the change in climate, which occurred around the year 1600, and its socio-economic fallout (Behringer 1997: Id., Behringer 2009); the scientific debate that framed many of the phenomena related to witchcraft (Clark 1997); the social conditions in village communities and how often bottom-up pressure gave way to trials against alleged witches (Briggs 2002); the reading of folk beliefs in light of heretical prosecutions and demonology (Kieckhefer 1976); the centrality of demonology (Ostorero 1995; Boureau 2004); and the role of humanistic culture in the developing of witch hunts (Montesano 2018). All of these, and many other approaches, have proven very useful for understanding witch hunts, but only as pieces of a puzzle.

This Special Issue of Religions dedicated to witchcraft, demonology, and magic features nine articles that deal with four different regions of Europe (England, Germany, Hungary, and Italy) between Late Medieval and modern times in different contexts and social milieus. Far from pretending to offer a complete picture, they focus on some topics that are central to the research in those fields. The role of monks and priests in performing occult sciences and ritual magic is analyzed by Rita Voltmer (Debating the Devil's Clergy. Demonology and the Media in Dialogue with Trials. 14th to 17th Century) in a long and articulated essay that takes into account the polemics between Catholics and Protestants in Germany, while Francis Young (The Dissolution of the Monasteries and the Democratisation of Magic in Post-Reformation England) focuses on the role of friars and monks in England before and after the dissolution of monasteries (1536-1540), which of course provided a turning point in their role as magic performers. Friars, especially Franciscan and Dominican preachers and inquisitors, and their 
understanding of the witchcraft phenomenon are central in Fabrizio Conti's article (Notes on the Nature of Beliefs in Witchcraft: Folklore and Classical Culture in Fifteenth Century Mendicant Traditions), this time seen from the point of view of a history of ideas. Fabiana Ambrosi (Giovan Battista Codronchi's De morbis Veneficis ac Veneficiis-1595. Medicine, Exorcism and Inquisition in Counter-Reformation Italy) and Ismael Del Olmo ("Such Fictitious Evil Spirits": Adriaan Koerbagh's Rejection of Biblical Demons and Demonic Possession in A Light Shining in Dark Places-1668) deal mainly with a history of ideas, concentrating their attention on two intellectuals: Giovan Battista Codronchi, a key figure of sixteenth-century medicine and Adriaan Koerbagh, exponent of the early Dutch Enlightenment, whose thinking is related to Thomas Hobbes. Many among the contributors deal with popular magic and beliefs or with the circulation of ideas in different social and cultural tiers. This is the case for Helen Parish ("Paltrie Vermin, Cats, Mise, Toads, and Weasils": Witches, Familiars, and Human-Animal Interactions in the English Witch Trials), who explores the vast domain of beliefs related to the metamorphosis of demons and witches in English trials, as well as for Vincenzo Tedesco (Treasure Hunt-Roman Inquisition and Magical Practices Ad Inveniendos Thesauros in Southern Tuscany) who studies archival sources looking for a practice, that of magical treasure hunts, which has a long and complicated history. Similar to Tedesco, Debora Moretti (Angels or Demons? Interactions and Borrowings between Folk Traditions, Religion and Demonology in Early Modern Italian Witchcraft Trials) devotes her study to central Italy and the Roman Inquisition's trials dealing with folkloric magic. Ildiko Sz. Kristof ("Charming Sorcerers" or "Soldiers of Satan"? Witchcraft and Magic in the Eyes of Protestant/Calvinist Preachers in Early Modern Hungary) gives an account of a topic not well known outside of Hungary: the definitions of witchcraft in Protestant/Calvinist preachers as read in Hungarian sources.

As a whole, those articles, some of them provided by young scholars at the beginning of their careers, show the variety of approaches as well as the vivacity and richness of current historiography and fit well within the current debate, suggesting that the puzzle of studies about witchcraft, demonology, and magic still needs many pieces to give us a better understanding of these multifaced phenomena.

Funding: This research received no external funding.

Conflicts of Interest: The author declares no conflict of interest.

\section{References}

Behringer, Wolfgang. 1997. Witchcraft Persecutions in Bavaria: Popular Magic, Religious Zealotry and Reason of State in Early Modern Europe. Cambridge: Cambridge University Press.

Behringer, Wolfgang. 2009. A Cultural History of Climate. Cambridge: Polity.

Boureau, Alain. 2004. Satan hérétique: Naissance de la démonologie dans l'Occident medieval. 1280-1330. Paris: Odile Jacob.

Briggs, Robin. 2002. Witches and Neighbors: The Social and Cultural Context of European Witchcraft. Oxford: Wiley-Blackwell.

Clark, Stuart. 1997. Thinking with Demons: The Idea of Witchcraft in Early Modern Europe. Oxford: Oxford University Press.

Gal, Florence, Jean-Patrice Boudet, and Laurence Moulinier-Brogi. 2017. Vedrai mirabilia. Un libro di magia del Quattrocento. Roma: Viella.

Geschiere, Peter. 1997. The Modernity of Witchcraft: Politics and the Occult in Postcolonial Africa. Charlottesville: University of Virginia Press.

Kieckhefer, Richard. 1976. European Witch Trials: Their Foundations in Popular and Learned Culture, 1300-1500. London: Routledge.

Kieckhefer, Richard. 1998. Forbidden Rites. A Necromancer's Manual of the Fifteenth Century. University Park: Penn State University Press.

Montesano, Marina. 2018. Classical Culture and Witchcraft in Medieval and Renaissance Italy. London: Palgrave/Macmillan. 
Ostorero, Martine. 1995. Folâtrer Avec Les Démons. Lausanne: Cahiers Lausannois d'histoire médiévale. Wachtel, Nathan. 1992. Dieux et Vampires_-Retour à Chipaya. Paris: Seuil.

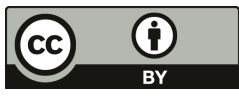

(C) 2020 by the author. Licensee MDPI, Basel, Switzerland. This article is an open access article distributed under the terms and conditions of the Creative Commons Attribution (CC BY) license (http://creativecommons.org/licenses/by/4.0/). 
Article

\title{
Giovan Battista Codronchi's De morbis Veneficis ac Veneficiis (1595). Medicine, Exorcism and Inquisition in Counter-Reformation Italy
}

\author{
Fabiana Ambrosi \\ Department of History, Cultures, Religions, Sapienza University of Rome, 00155 Rome, Italy; \\ fabiana.ambrosi@uniroma1.it
}

Received: 5 September 2019; Accepted: 28 October 2019; Published: 4 November 2019

\begin{abstract}
The physician Giovan Battista Codronchi (1547-1628) is a key figure of sixteenth-century medicine. A study of his main work De morbis veneficis ac veneficiis (1595) and his letters sent to the Congregation of the Index in Rome (1597) can teach us much about the interrelation between medicine and religion in Counter-Reformation Italy. Using Codronchi as a prism, this article uncovers a complex picture in which themes such as the production of demonological texts at the height of the European witch-hunt, the related debate about the roles of physicians and exorcists, and the influence of physicians on the development of the Index of Forbidden Books are interrelated.
\end{abstract}

Keywords: medicine; demonology; gynecology; inquisition; censorship; counter-reformation Italy

In 1595, the physician Giovan Battista Codronchi published the treatise De morbis veneficis ac veneficiis (On Poisoning Diseases and Poisoners). Although Codronchi described the text as an accidental result of his reflections on the diabolical illness that struck his daughter Francesca, it represented a crucial step taken by Codronchi in order to participate in the religious policies of the Catholic Church. A couple of years later, Codronchi sent a letter to the Congregation of the Index in Rome containing a lengthy list of medicine books to be expurgated (Baldini and Spruit 2009, pp. 607-19). If we read the two sources together, Codronchi's project of bringing medical and religious orthodoxy into communication with each other and to the attention of authorities in Rome, becomes clear.

Indeed, long before the possession of little Francesca, Codronchi had already played a leading role in the political and religious life of the city of Imola. He was nominated commissioner for the finances (1590) and "ensign bearer" (1590). Even before that, Codronchi had been nominated to the commission appointed to oversee the establishment of the Jesuit college in Imola (1581). Together with his brother Tiberio, Codronchi was a key figure in the project. (Ferri 1997, p. 37) Moreover, when a medical meeting was assembled in Imola in 1591 in order to discuss how to deal with the plague, Codronchi was absent due to health reasons. But he sent the city council a document so to make his contribution: in order to "preserve the city of Imola from all bad and contagious evil" he proposed to "begin with spiritual commissions" (Mazzini 1924, p. 6).

His political commitment always proceeded hand in hand with his faith and his medical profession, and the letter he sent to the Congregation of the Index constituted the very peak of his attempts to create a direct connection with Rome.

The religious behavior of early modern Italy was marked by a peculiar intertwining of popular magic, religion and of the consequent repression of dissent. (Ginzburg 1966, 1989; Romeo 1990, 2008b; Di Simplicio 2005). Already in the Middle Ages jurists, theologians and philosophers questioned the power of Satan and the possibility of his action in the physical world. But it is in the Early Modern period, in the midst of the great European witch-hunt, that demonology emerged as a coherent discourse which systematized beliefs about the demonic (Clark 1997b). Although skeptical voices 
about the witches' powers were already present at that time—and indeed, they predated belief-dissent actually encouraged the continuation of the debate between the supporters of persecution and the “witches' advocates" (Valente 2008; Machielsen 2011; Duni 2012, 2016). In Italy, it was originally inquisitors-especially Dominicans, as the author of the Malleus Maleficarum had been-who led the way in confronting the problem of witchcraft in print (Tavuzzi 2007; Romeo 2008a; Herzig 2008, 2017). Yet, the second half of the sixteenth century saw a noticeable shift in authorial production, with exorcists and physicians dominating the market (Lavenia 2011). This unusual state of affairs may have been due to the fact that witch-hunting in Italy did not reach anywhere near the dimensions witnessed in many other parts of Europe (Levack 2006; Monter 2006).

The institution of the Roman Inquisition (1542) certainly had a considerable impact on this process, since it represented a unitary bond within a territory that was otherwise politically and socially unconnected (Romeo 2002; Brambilla 2006; Prosperi 2006; Mayer 2014). From its headquarters in Rome, the Inquisition coordinated courts across the peninsula (Aaron-Beller and Black 2018). It managed to limit the operational liberties of the local dioceses by establishing specific provisions for witchcraft (Tedeschi 1990). It thus prevented the recurrence of the violent anti-witches campaigns that had occurred in northern Italy at the end of the fifteenth century and at the very beginning of the sixteenth century (Prevideprato 1992). The Inquisition's original focus on stemming the spread of Protestant heresy and strengthening papal authority over the Council might well explains its skeptical attitude towards witchcraft.

Only in the 1570s, when the threat of heresy had subsided, did the Holy Office begin to pay more attention to witchcraft as part of a wider struggle against superstition which culminated in the promulgation of the bull Coeli et terrae (1586) by Pope Sixtus V (Ernst 1991). Yet, even then, the official approach towards witchcraft was less than clear-cut and the bull likely inadvertently led to a further decline in the number of trials (Bever 2009). Because Coeli et terrae invalidated the distinction between simple and heretical magic, it deprived diocesan courts of their remaining jurisdiction in witchcraft cases. This step towards further centralization represented a turning point in the management of 'the supernatural' in Italy, since it reaffirmed Rome's exclusive control over the supernatural, the sacred, and legitimate rituals, all of which were threatened by popular practices, especially in the realm of healing and medicine (Valente 2015; Donato 2019).

As a part of the battlefield between bishops and inquisitors over jurisdictional competence, local exorcists-in their voluminous publications-often blamed the spread of witchcraft on the excessive cautiousness of inquisitors and managed to give their contribution (Romeo 1990; Dall'Olio 2001a, 2001b). Exorcism manuals circulated mostly among the clergy, aimed to help the priests to identify and confront demonic manifestation (Caciola 2003), filling the vacuum created by perceived institutional inaction. Inevitably, such individual enterprising by local priests made fears of witchcraft and demonic possession worse, even in some of Italy's major cities. It is no coincidence, therefore, that most exorcism manuals were ultimately included, along with some of the European demonological treatises, in several Indexes of Forbidden Books, albeit not until the early eighteenth century (Lavenia 2005; Brambilla 2010, p. 79; Valente 2012). When the boundary between heresy and orthodoxy proved both malleable and very easy to cross, this sort of priestly do-it-yourself literature left too much space for actions from below (Romeo 1990, p. 113). In this respect, Codronchi's De morbis veneficis seems to be precisely halfway between ecclesiastical concerns and exorcists' intentions. As a learned man, he could be properly included among Italian demonologists such as Girolamo Menghi or Silvestro Mazzolini, founders of early modern Italian exorcist literature. Yet, in contrast to other authors, witch-hunting was not Codronchi's concern and indeed, neither in his treatise nor in the archives can one find any proof of Codronchi's attempt to legally pursue the person alleged to have bewitched his daughter. ${ }^{1}$

1 In the inquisitorial records kept in the diocesan archives of Imola, Busta 1 of the Series Processi contains three Registers, which, in total, contain the trial papers from 1551 to 1595 . From the published inventory (Ferri 2001) appears that Register 3 opens with the trial of 8 January to Ioseph de Cremona with the accusation De propositionibus, as well as from the manuscript 
Codronchi's De morbis veneficis represents a major contribution by a physician to the early modern demonological debate. Codronchi opens the work by expounding its autobiographical origins. His daughter Francesca was only ten months old when she suddenly began to lose weight. The child had been entrusted to a wet nurse, but in a short space of time, she grew thin and started whining incessantly. She cried constantly, much more than children normally do at her age. Her symptoms were not recognized as a known illness and consequently, the child's conditions continued to worsen. Gradually, Irene Teodosi, her mother, began to suspect that someone had put a spell on her child, moved by hatred or envy. Objects often associated with witchcraft were found in the infant's cradle, including peas, grains of coriander, a chip of apparently human bone, and even some sort of blood lump described as being made of the menstrual blood of a devilish woman. Thoroughly alarmed, the parents got her wet nurse dismissed and entrusted the child to an experienced exorcist. After three days, she showed signs of improvement. Before she was entirely cured, however, the child relapsed, and again, strange objects were found in her cradle. In the end, however, the exorcist managed to heal her. ${ }^{2}$

With the publication of the De morbis veneficis, a work influenced not only by personal experience but also by European demonology and by manuals for inquisitors and exorcists, the devil enters Codronchi's medical analysis. However, after explaining the reasons that led him to take an interest in the diabolical, he took care to state that "the malefice was probably allowed by God himself, in order to experience in my own daughter what in others I would have hardly believed to be true". ${ }^{3}$ Thus, he takes personal responsibility for his daughter's illness and also avoids to fall into the trap of dualism - a perennial problem for demonologists—but rather emphasizes the primacy of God even in his daughter's possession episode. This was, indeed, a common approach in all demonological analyses, since Christian authors needed to avoid any implication of Manichean dualism by stating that diabolical forces act only with God permission (Cameron 2010).

Although unexpected from the perspective of northern demonology, the De morbis veneficis fits perfectly within the typically Italian demonological literature (Tavuzzi 1997; Maggi 2001, 2006; Valente 2003; Lavenia 2011; Machielsen 2015; Dall'Olio 2018). However, what makes the text particularly interesting is that it is among the first contributions to be authored by a physician. Within the Italian demonological debate, dominated by Inquisitors and exorcists, physicians were often criticized. The idea that the occult played a role in the physical world was by then established and shared, and the inefficiency of official therapies was proof of this (Clark 1997a; Lavenia 2013). Thus, the significance of the De morbis veneficis is the way that its author sought to bring these two disciplines together in the service of Tridentine reform.

Despite its autobiographical origins, the structure of the De morbis veneficis resembles that of other demonological texts. Divided into four volumes, the first surveys source from antiquity. Biblical and then patristic sources are followed by the most authoritative sources in the fields of medicine and

inventory on the folders. Actually, the register begins from page 61, and the first available trial is the one against Maddalena Valgo la Fenzarola, on 17 March of the same year. Among the lost papers there are also the trials with accusation De sortilegis against Francesca Brocardi (17 February) and Giulio Segantino (20 February). In light of the date of the trial, Brocardi could have been the most plausible wet nurse of Francesca Codronchi, suspected and fired, but without the papers it is impossible to ascertain. Going backwards chronologically, there are only two trials of alleged witches, both in the summer of 1559 . Thus, even if Codronchi denounced the wet nurse, it seems impossible to find her identity.

2 Codronchi (1595), ff. 35v-36r: "Et illud tantum memorie prodam quo mini fat erit, annis enim superioribus Francisca filia mea decem menses nata apud nutricem insigni macie est affecta, sæpe, ac sæpius, magna suspiria edebat. Et quando difasciabatur semper plorabat ægreque ferebat se defasciari præter puerorum morem qui quamvis sint male affecti vel dolore aliquo detenti cum fasciæ suluūtur quiescere ac delectationem capere tum solent nulla inventa causa præternaturali affectus, nutriceque mutata, cum indeterius laberetur sub iit suspitio uxori meae, ut cum esset pulle admodum venusta invidentiæ causa, vel odii cuiusdam vetule veneficio esse affectam. Qua propter culcitram inquirens nonnulla signa veneficii reperit, cicéros, nempe, grana coriandronum, frustum carbonis, et ossis defuncti, rem quandam compactam miei incognitam, quam fieri ab his improbis forminis ex quibusdam cum sanguine menstruo mixtis, retulit, quidam penitus exorcista."

3 Codronchi (1595), f. 36: "quod quidem veneficium portasse Deus permisit ut in mea puella experirer quod in aliis parum credebam veritatis habere". 
natural philosophy. Probably following the footsteps of the physiologist Jean Fernel, with whom Codronchi had a controversial relationship (see below), and preparing the ground for authors such as Candido Brugnoli (Biondi 1994; Niccoli 2001), Codronchi discusses the traditional authorities who dealt with natural causes and supernatural interventions. Of course, he also took his contemporaries into consideration: for example, he surveys Girolamo Menghi's theories about the enormous power of Satan and his army and about the possibility of fighting them through exorcism, which are summarized and readapted in a wider context. Emphasizing his autobiographical testimony and his medical training, Codronchi's work attempts to highlight the scientific questions implicated in demonology.

The first source that Codronchi submits in support of his argument is Scripture itself, a choice that already partially communicates the heart of Codronchi's message. In the Bible, the devil embodies evil, which was unwanted yet permitted by God, since the first to embody it were his own creatures, the snake and humans of the third chapter of the Genesis. Possibly, Codronchi's exclusive use of Old Testament biblical passages in his opening chapters suggests his main concerns. In fact, Codronchi does not refer to the very few passages in which the devil is actually named, but only to those which condemn the use of divinatory and magical arts which challenge the greatness of God. ${ }^{4}$ The devil thus takes advantage of the illicit attempts by humans to communicate with the divine through magic (Heintz 1997).

Not only on a strictly theological level but also on a political one, magic was considered as the work of the devil, and insofar, Christians opposed it from the outset (Flint 1999; Marasco 2011). In addition to Scripture, Codronchi draws on the canons of Church councils. These recognized that magic was not simply a pagan practice, but also one illegitimately pursued by curious or badly educated Christians. Codronchi denounces both necromancy and divinatory arts, since communication with the deceased and the prediction of the future are powers denied even to the Church. The only true prophetic knowledge is that contained in Scripture. For this reason, Codronchi refers to Canon 36 of the Council of Laodicea (AD 363/364), which states that churchmen could not be magicians, charmers, or astrologers and that they could not make amulets. Those who matched this description must be expelled from the Church. ${ }^{5}$ Similarly, Canon 89 of the Fourth Carthaginian Council (AD 348) condemned spells and divinations of the participants of the church and denounced Jewish superstitions.

Other canonical sources included the Decretum Gratiani (twelfth century) which, similarly, denounced magical practices as superstitious and antithetical to Christian orthodoxy, and the bull Summis desiderantes affectibus (1484) issued by pope Innocent VIII, which prefaced Institoris' Malleus Maleficarum (1486). Moreover, further support was given by the Church Fathers. From Augustine to Thomas Aquinas, Codronchi surveys the judgment of the Fathers on magic and divination, unanimously condemned as undesirable to God. Reviewing the theological and philosophical literature was a typical aspect of demonology as well.

As for his treatment of classical sources, Codronchi welcomed the theses of "Plato and the Platonists, for whom the veneficium is evil" (Codronchi 1595, f. 13) while he openly opposed Aristotelian positions, since "the demons and their evils, in the opinion of Aristotle and the Peripatetics, cannot be proven by virtue of their own [by Peripatetics] principles" (Codronchi 1595, f. 16). Obviously, the dualistic philosophy of Plato accorded better with the explanation of intelligible causes manifesting through sensible effects. In addition, later Neo-Platonic philosophy interpreted the demonic as transcending the human sphere but not corresponding to the divine; demons were considered intermediate beings. Following this interpretation, during the early modern period, many physicians embraced the idea of the possibility of the hidden causes of diseases (Bianchi 1982; Clark 1997a; Forrester 2005). The rediscovery of Platonic literature due to the translation from Green to Latin and the renewed circulation of Hippocratic Prognostica, together with the always potential failure of official medical therapies,

\footnotetext{
Ex 22,18; Lv 19,31; Lv 20,6; Lv 20,27; Dt 18,9-12; 2Re 1,3-6.

Codronchi (1595), ff. 5v-6: "Auguriis et incantationibus serventem a conventu ecclesia separandum similiter et superstitionibus judaicis, vel feriis inhaerentem".
} 
led the early modern physicians to think that there were diseases with obscure and incurable causes (Lavenia 2013). Codronchi similarly dismissed attempts to advance naturalist explanations, often rooted in the power of the imagination, for diseases. He considered such naturalism, associated with the controversial figure of Pietro Pomponazzi totally inadequate to explain diabolical phenomena (Dragon 2006). The second book of the De morbis veneficis is entirely devoted to explaining how the human imagination cannot be the origin of any veneficium ${ }^{6}$ (Zanier 1975, pp. 65-67). When Codronchi denounced Aristotelians for their denial of demons, he likely had naturalists like Pomponazzi in mind. Moreover, in a strictly philosophical and physiological sense, we may deem that the critical point is right on the coincidence of body and soul. Since the devil is the "prince of the substance", and possesses bodies and not souls, Codronchi's refusal of both Aristotle and Galen lies in that attempt to bring a body's issue to the soul and vice versa (Zambelli 1996). In other words, while he is ostentatiously and scrupulously orthodox where Christianity is concerned, Codronchi is deeply critical of both philosophical (Aristotelian) and medical orthodoxy. The science of Hippocrates and Galen also foresaw that assumptions about demons and venefici could not even be postulated and that the causes of diseases both internal and external had to be investigated only by sensory methods. However, it is clear that every disease needed its own medicine. Inevitably, if physicians rejected the demonic cause and tried to cure this kind of disease through the introduction of blood or the administration of drugs, they would necessarily face therapeutic failure since such remedies are ineffective on demons, which are substantiae. ${ }^{7}$ Codronchi does not deny the humours and elements, which are the central foundation of the Hippocratic-Galenic physiology, but Hippocrates, the 'prince of physicians', in his treatises on sacred disease had made malefic actions a mere matter of 'wrong words'-i.e., empty belief-which Codronchi cannot accept. ${ }^{8}$ Of course, God cannot be the cause of such "sacred" diseases; although the reference is made to a 'sacred' evil, the cause of such diseases must therefore be sought in demons. The followers of Hippocrates and Galen, who do not admit that sacred evils such as Codronchi define them, simply follow the authorities because they do not really understand the point of the matter. ${ }^{9}$

In Book Four of the De morbis veneficis, Codronchi explicitly states his position concerning the relationship between magic, medicine and exorcism. He confronts the therapeutic pluralism of the time by appealing to the principles of 'ex magica arte, ex religione et ex arte humana' (Codronchi 1595, f. 165v) and focusing on the pharmaceutical culture of the herbs and potions (Gentilcore 1998, p. 2; Minuzzi 2016). Early modern medicine was a discipline characterized by a deep ambiguity because it was at the same time both ars and scientia (Mammola 2012). This ambiguity was especially evident in the healing process, which was assigned from time to time to different practitioners. At the risk of oversimplification, while the learned physician might consider the study of medicine a science, other parts of the therapeutic marketplace, such as charlatans and healers, were more concerned with the ars, the care of patients (Pomata 1998; Gentilcore 2006). Furthermore, the early modern medical marketplace was not only a secular competence; physicians also faced competition from the clergy (De Blécourt 1994; Duni 1999). These lines often blurred in practice. While clerics, especially, of course, exorcists, would participate in healing rituals, they also produced ointments and other preparations

6 Codronchi (1595), f. 45: "Quid sit veneficium ex aliorum sententia explicatur et immaginationem illius non esse causam probatum".

7 Codronchi (1595), ff. 20v-21r: "Et morborum causas cum internas, tum externas disquirentes a sensibilibus, non as insensibilibus (quales sunt daemones) indagati fuerint. Praeterea cum causarum morbos facientiunt abolitio a contrariis fiat. Contrariorum contraria sunt medicamenta. Et pro diversis morborum causis, eorum varientur medicationes: quanta ratione daemoniaca morbi causa supposita a medicis ipsis depelli poterit. Quaenam sanguinis missio, quae concoquentia quae purgantia pharmaca, quae victus ro, vel alia huius generis medica remedia fuerint vel daemoniaco eius morbo contraria cum daemones sint substantiae".

8 Codronchi (1595), f. 21v: “Hypocrates enim Medicorum facile princeps in libro de sacro morbo, de Magis seu Maleficis, deque eorum operationibus pravis verba facit".

9 Codronchi (1595), f. 24v: "[ . . ] ] medici nimis Galeno addicti et qui ut dicitur in eius verba iurarunt, hoc morbos non admittant ut qui causam abditiorem et non physicam possideant". 
as a result of long-standing monastic tradition. Conversely, popular healers often supported their treatments with prayers and blessings (Zanelli 1992; Pomata 1999; Weber 2011).

Building on ethical rules that he had already articulated in his earlier De Christiana ac tuta medendi ratione (1591), Codronchi made it clear that both physicians and their patients had a duty to confront vices through conversion to Christianity or reconciliation with the Church (Schleiner 1995). Those same notions are here confirmed and adapted to the context of diabolical diseases: Codronchi insists on the need for those affected by demons to seek refuge with God, imploring Him with prayers and supplications and confessing their sins through the sacrament. ${ }^{10}$ Again, rather than identifying a human culprit, Codronchi is focusing on patients reforming themselves. Medicine and religion are both necessary in the healing process.

From the outset, Codronchi encouraged the prevention and cure of venefici through the "rejection of superstitious methods and the acceptance of real Christian remedies". ${ }^{11}$ He gathers the knowledge that was normally the prerogative of apothecaries, pharmacists, and herbalists, to illustrate how the properties of some plants can be used to contrast some of the symptoms caused by the diabolical intervention. However, as Codronchi is a learned physician, before delving into the science of botany and pharmacy, he clarifies that the purpose of physicians is the preservation or attainment of health. Anyone who aspires to be a physician needs to keep things as they are according to nature and to preserve their bodily constitution as well as their health. ${ }^{12}$

The value of some officinal remedies, in particular those ascribed to Pliny and Dioscorides, but also to Democritus, is here reaffirmed. However, like Galen, Codronchi considers the remedies used as amulets "vain and superstitious". These included, for example, the "scilla", a liliaceous plant used by Pythagoras as a remedy for all evils (Jouanna 2011). ${ }^{13}$ Nevertheless, the dividing line between therapeutic and superstitious medicines is often very thin. According to Codronchi, this ambiguity is due to the fact that, in ancient times, divine and demonic conceptions of the venefici were unknown and indistinct, and that both were simply defined as magical. ${ }^{14}$ He prefers "to silence" (Codronchi 1595, f. 170) the many who have applied superstitious methods against the venefici but recognizes that there actually are some potions and medicaments which can be preventive in case of enchantment. His assumption is that since demons work within nature, there are natural remedies with a real healing power over diabolical diseases, and physicians may use them when dealing with patients suffering from spell-caused diseases (Biondi 1981). As the properties of some plants can alter the natural manifestations of things, a real collaboration between the disciplines is key to treating this kind of disease. ${ }^{15}$ Exorcists often transcend the medical field when prescribing and preparing drugs, but, by doing so, they risk causing further injury to the patient, since some remedies may become

10 Codronchi (1595), f. 175v: “Qui igitur veneficio aliquo sunt affecti, vel a daemone obsessi, quamprimum ad Deum optimum maximum confugere debent, et orationibus sedulis ac devotis auxilium ipsius implorare, peccata propria dolendo sacramentaliter confiteri, sacra communione saepius se munire, vigiliis, ac ieuniis si vires sint validae carnem attenuare, ac ipsius impetus imminuere, varia itinera peragere $[\ldots]^{\prime \prime}$.

11 Codronchi (1595), f. 161: "De praeservatione a morbis veneficis, pro qua remedia superstitiosa reiiciuntur, et vera Christianaque proponuntur"

12 Codronchi (1595), f. 161: "Cum medici finis sit sanitatis custodia, seu adeptio, quicquid enim in arte sua molitur medicus, ob id facit, vel ut praesentem servet quae secundum naturam est, constitutionem quam sanitatem dicimus velut amissam illam sedula manu recuperet atque reficiat, ea propter primo loco qua ratione sani, ne a veneficis morbi corripiantur, deinceps, quibus remediorum generibus aegrotantes a veneficiis vindicari possint, explicare aggrediar"

13 Codronchi (1595), f. 161v: "Antiquiores idolis servientes pro ipsa praeservatione quibusdam vanis ac superstitiosis quae amuleta dicuntur, utebantur, quae tamen neque a temperamento, neque ab aliis manifestis qualitatibus, neque a tota substantia, neque a divina, vel magica potestate vires habent $[\ldots]$..

14 Codronchi (1595), ff. 169v-170r: "Cum antiqui divinam ac demoniacam rationem veneficia solvendi distinguere ignorarent, utramque magicam appellabant et sacram, divinamque existimabant, ac in religione habebant, unde Hippocrates divinum vocavit, quod in morbis habetur, cum potius daemonium esset dicendum, magica curatio utitur quibusdam vanis ac superstitiosis rebus ac verbis quae ut superius fuit dictum, Amuleta dixerunt et incantationibus adiurationibusque daemoniacis".

15 Codronchi (1595), f. 169v: "Pro curatione horum morborum, et demonum corpora obsidentium expulsione, tres invenio rationes inter se maxime distantes, quarum una ex Magica arte, alia ex Religione, et tertia ex arte humana dsumitur, ita ut curatione dividere possimus in magicam, divinam et humanam". 
dangerous if not handled cautiously. ${ }^{16}$ The advocated pharmacology is actually quite traditional. Among emetics, for example, Codronchi recommends dill seeds, atriplice roots and horseradish, which are often prescribed in order to induce moderate vomiting. However, white hellebore must be used with caution: although it is the main ingredient of medicines which provoke vomit and therefore purify, this remedy must be calculated and administered carefully; by eliminating the harmful humours accumulating in the brain, wrong quantities can lead to diuresis and excretions and determine a new induced humoral imbalance. Given the attention required from physicians when administering emetic drugs, even greater caution is expected from the exorcists and hopefully, they will not have to act autonomously.

In cases of possession, Codronchi articulates the need for collaboration much more: "both the prudent exorcist and the physician will be able to prove that many diseases provoked by witchcraft can be eradicated almost with the same remedies and with other things related to their universal cure" ${ }^{17}$ Unlike Menghi's demonology, in which physicians had no power over diabolic illnesses, Codronchi wishes for a collaboration between physicians and exorcists, and indeed, he considers such a partnership necessary. For Menghi, it is the exorcist who is in charge of the medicinal administration, as well as of the supervision of the ritual. ${ }^{18}$ Obviously, exorcism was not similar to other unofficial treatments: the operation was not constituted of a single therapeutic act performed by a healer, but it was a ceremony (Sluhovsky 2007; Young 2016). The ritual of exorcism was entirely administered by the exorcist who worked in the name of the Church. Codronchi did not disagree with this interpretation of exorcism. By distinguishing the roles belonging to physicist and exorcist, however, Codronchi advises the exorcist to collaborate with a health professional when performing the sacred rite. Codronchi explains the need for a physician by appealing to the substantial nature of demons. Conversely, the exorcist, insofar as he is a divine emissary, is responsible for the spirit of the patient. As he did in the case of Francesca's possession, Codronchi coherently took care of the physical health of the child himself while allowing God, through the exorcist, to act on the spirit of the poor possessed.

Two years after the publication of the De morbis veneficis, Codronchi sent a letter to the Inquisitor of Imola, Head of the Inquisition in his diocese; the letter contained some extracts of "magical and superstitious remedies to be expurgated from the works of physicians". With his letter Codronchi aimed to join the process of expurgation of forbidden books (Donato 2009). On 5 January 1597 Alberto Cheli, Inquisitor of Imola and Faenza, delivered the letter undersigned by Michele da Lugo, Vicar of the Sant'Uffizio in Imola, Federico Surdo, General Vicar of Imola, and Alberto Cheli, General Inquisitor of Romagna, to Cardinal Marcantonio Colonna, prefect of the Congregation of the Index in Rome. (Fragnito 1997, pp. 143-71; Frajese 1997, pp. 120-27). Although the exchange among the three men was minimal, it reveals how tangled the entire mechanism of expurgation was: in his discussion of Huarte's Examination of Men's Wits, a book already forbidden by the Spanish Indices, Cheli writes to Colonna that he found "heretical propositions which are suspect and outrageous". ${ }^{19}$ He then adds:

16 Codronchi (1595), f. 177r: "Et quoniam nonnulli Exorcistae posuerunt falcem in messem medicorum, proponentes varia vomitoria, potiones, linimenta, suffitus, balnea et alia huiusmodi, quibus fine ulla differentia ac temerem, artem profitentes hanc utuntur insigni cum aegrotantium laesione $[\ldots]^{\prime \prime}$.

17 Codronchi (1595), f. 199: "Quamplures alii venefici morbi eisdem ferem remediis, ac aliis relatis in cura universali, aboleri poterunt, quae prudens Exorcista, ac Medicus adhibere poterunt".

18 Menghi, pp. 275-76: "Non è adunque da dubitare che Iddio, à vendetta della sua divina giustitia non sottoponghi gli Demoni alle attioni delle cose sensibili. Ma qui avertifica il lettore che se questo Dottore intendesse, che questo si possi fare senza gli Essorcismi di Santa Chiesa diria il falso. [ . . . ] Gli Sacerdoti et Essorcisti possono applicare alcune cose sensibili à questi vessati dal Demonio per alleggerire la loro vessatione fattagli da questi spiriti immondi; mentre però che dette cose siano benedette nel nome della santissima Trinità, Padre, Figliolo, et Spirito Santo. Non è adunque cosa d'ammirarsi se alcuni Essorcisti applicano certi siropi, medicine et altri beveraggi à questi spiritati per scacciare gli Demoni fuori de i loro corpi; sendo chiaro (per quello che habbiamo detto) questo non solamente essere lecito, ma ancho alle volte necessario, per cavare gli maleficij fuori de i corpi maleficiati et fatturati, mediante i quali il Demonio è legato in quelli corpi, per il patto che tiene con gli Malefici".

19 The book was forbidden by the Spanish Inquisition in the Indexes of 1583 and 1583; the first condemnation appeared in the portuguese Index of 1581, where the book was forbidden without the name of the author. The book was never forbidden by the Roman Indexes. 
"Likewise I am going to send you a list of medical books, compiled by Sir. Baptist Codronchius of Imola, who was in charge of the correction of Medical books; he observed [ . . . ] some passages about Galen etc., which I am going send to you" ${ }^{20}$ On 8 March 1597, a decree by the Congregation of the Index appointed the work of expurgation of medical books to a commission based in Padua. The same decree also acknowledges receipt of Cheli's letter containing Codronchi's suggestion by the Index. ${ }^{21}$ (Baldini and Spruit 2009, p. 621; Ricci 2008, pp. 363-76) In May, Cheli wrote to Colonna again, sending him another list compiled by "Sir Physician Baptista Codronchius of Imola". The possibility cannot be excluded that, in addition to the Paduan commission, another delegation from Romagna had been engaged, and that Codronchi was part of it. The main evidence for this conjecture is a letter written by the bishop of Faenza Antonio Grassi and dated 21 December 1596 which informs the Congregation that "in order to get rid of the forbidden books and to correct those that need adjustments, we appointed some men who are learned about all the sciences" (Marcus 2018, p. 20). Moreover, we should consider that Alberto Cheli had been commissioner of the Holy Office in 1566 and 1567, and that in 1581 he had been nominated vicar of the Inquisition at Imola. After Faenza was raised to the status of an independent Inquisitorial seat in, Cheli returned there as general Inquisitor until 1599: it is in this time frame that Cheli mediated between Codronchi and the Congregation of the Index in Rome (Schwedt 2013, p. 51). Possibly, a previous acquaintance during Cheli's stay in Imola as vicar of the Inquisition, as well as shared political and religious interests between the two, may have prompted Codronchi to contact Cheli again after the promulgation of the 1596 Index.

The list is quite long, its content heterogeneous, and the assumptions laying behind Codronchi's choices are manifold. Yet, together, they reinforce the picture of Codronchi's project of putting medicine at the service of religious reform and, in turn, using religious orthodoxy to reform medicine. It is worth noting that most of the expurgations concern texts concerning epilepsy. First, Codronchi quotes some extracts from the thirteenth and sixteenth sentences of Scribonius Largus' Compositiones Medicamentorum in which the first-century author proposed some methods for diagnosis, preparation, administration and preservation of the morbo comitiale. In order to treat epilepsy, the thirteenth Compositio recommends taking the gastric juice of a fawn collected within nine days from its secretion, to let it dry "neither by the light of the sun nor by the light of the moon", and to administer it in the quantity of the size of a single lentil. Furthermore, it advises killing the fawn "with a knife a gladiator had been slaughtered with" (Largus 2016, p. 39). Similarly, the sixteenth Compositio describes a treatment practised in Rome by an 'honest matron' and based on the use of animal blood. ${ }^{22}$ The Compositiones of Scribonius circulated widely in the early modern age, especially in Protestant countries. ${ }^{23}$

Next, Codronchi turns to Alexander Trallianus' De epilepsia (sixth century). The De Epilepsia represents chapter 15 of Book I of the Therapeutica, entirely dedicated to diseases affecting the head; as Alexander explains, epilepsy is a pathology located in the head. Ill people in the acute phase 'can neither listen, nor see, nor completely understand, nor remember anything. They lie without any sensitivity and differ in nothing from the dead' and still 'some people call this disease as sacred because the brain is sacred and honored' (Alessandro di Tralles, pp. 640-43). Hippocrates' naturalization of this once sacred disease forced the medical tradition to address the problem of its possibly physical or spiritual nature. Alexander Trallianus interprets epilepsy in the light of the Neoplatonic philosophy, and, for this reason, after having described the disease and its causes, he devotes a whole book to the

20 'Parimente mando un'Indice di libri in matteria di Medicina, osservati dal S<igno>re Baptista Choderoncho, Imolese, deputato sopra la correttione de libri Medicinali, quale hà osservato de [ . . . ] passi sopra Galeno etc. quali mandarò a V.S. Ill $<$ ustrissi $>$ ma et $\operatorname{Rev}<$ erendissi $>$ ma.

21 "censurae in quaedam opera Medicinalia receptae sunt ab Inq<uisito>re Faventino".

22 "merge an hemin of ivory filings and a pound of attic honey. Then, if the patient is a boy, you add the blood of a male tortoise and a male pigeon, both wild, [ . . ] instead, if the sick person is a girl, the animals must be of female sex as well [ ... ]. Who uses this medicine must not taste neither wine or pork, and has to keep an ivory bracelet on his arm".

23 All the editions were based on the Parisian edition of 1528 edited by the French physician Jean Du Rueil. The text was published afterwards in Basel in 1529 by Andreas Catander in Venice in 1547 and it was then printed in Paris in 1567 by Henri Estienne. 
magical remedies to be used to cure the illness. Inevitably, it is precisely this last section that is targeted in Codronchi's proposal for censorship. Codronchi also suggests the expurgation of other parts of the work of Alexander which no longer concern epilepsy, but still recommend magical remedies to fight hiccups (Lib. 7 chap. 15), kidney stones (Lib. 9 chap. 4), intestinal colic (Lib. 10 chap. 1), and fevers (Lib. 12 chap. 7).

Next, Codronchi focuses on Nicolaus Myrepsius's De compositione medicamentorum (thirteenth century). Chapter 353 describes the remedies used by married people who hated each other because of a maleficium. ${ }^{24}$ Codronchi proceeds to expurgate antidote 298 which claimed that evil spirits are driven away by the ciphers, an ancient perfume used by Egyptian priests, antidote 405 which recommends prayers, formulas and magical observations in case of exaggerated blood flow, and antidote 419, which describes some general magical remedies. ${ }^{25}$ Finally, Codronchi proposes the expurgation of sections $21,12,24$ and 37, which suggest the employment of superstitious remedies and magical words for the treatment of internal and external tumors. ${ }^{26}$

Other types of expurgation deal with maternity and female diseases. Of the four volumes of the Rerum Medicamentorum by Theodorus Priscianus (fourth century), Codronchi suggests the expurgation of the first part of the Gyneciorum Harmoniae, and, in particular, of the parts concerned with remedies to help or to prevent conception. The text originally constituted the third book of Priscianus' Euporiston, which illustrated remedies that could be adopted even by non-specialists (Formisano 2004). In order to further spread medical knowledge, it was Priscianus himself who published a second abridged version of the book in Latin, the only version now actually preserved. Priscianus advised women who wished to avoid pregnancy to adopt magical remedies in order to suspend their fertility. ${ }^{27}$

Then, Codronchi addresses chapter 8 and 29 of Isaac Israeli's Pantegni, concerned, respectively, with gynecological and obstetrical remedies and male impotence caused by magic. ${ }^{28}$ Since this pathology was often deemed to originate in maleficium, the prescribed cure had to be just as magical. However, it is also plausible that Codronchi's strong anti-Jewish attitude may have encouraged this proposal (Romeo 2005). In fact, already in the De Chistiana, Codronchi had dedicated an entire chapter to the restrictions that Christian physicians should have observed when consulting Jewish physicians (Codronchi 1591, ff. 110-13; Schleiner 1995, pp. 103-4).

Other proposals examine Giovanni Michele Savonarola's Practica Maior (1561), and, in particular, heading 20 of chapter 1, which causally connected epilepsy to the female menstrual period and encouraged the use of magical remedies and prayers. Section 32 of chapter 20 is also targeted, insofar as it offers therapeutical solutions against male impotence. ${ }^{29}$

Next, Codronchi proposes the expurgation of Niccolò Falcucci's Sermones Medicales (1491) specifically, sermon 3, which describes how to force the blood flow through enchantments (chp. 2), sermon 6, dedicated to the anatomical, physiological and therapeutical analysis of the reproductive

24 "ad coniugatas quae viros aliquo maleficio invicem odio habent".

25 "ad extirpandas mariscas adhibit si neriosis radice cum quibusdam vanis observationibus [ ... ] ob huius libri defectum non potui singillatim haec magica rimedia describere, quae alias notavi sic".

26 "ad malum spiritum fugandum nonnulla proponit sortilegia".

27 "Cum peperit mulier eadem hora antequam aliquid suma, aut sanguis eius purgetur, tolle carbones vivos, et extingue eos in sanguine suos idi ter dicens: extinguo conceptionem mulieris huius, et nomina eam, ab omni coitu virili ex hai die vel ex hac hora qua ipsa voluerit, salvis eius menstruis etc. Et statim carbones in pixide pone quantum volueris, et claude deinde ipsam pixidem in lisitro involve, et diligenter liga et signa, et absconde eam, ut non aperiatur, ita ut nec sol nec luna eam videam".

28 Israeli's work was divided into two parts, Theorica and Practica, each divided into ten chapters, and the same division was followed by the translator Constantine the African who gave it the name of Pantegni. The 1536 Basilean edition contains only the Theorica part. Instead. Codronchi refers to the Practica that is found only in the Lyon edition of 1515 , but that, as highlighted by Monica Green, has little to do with the original Arabic, and can be considered almost entirely the work of Constantine. (Green 1994).

29 Michele Savonarola then took up to some sections of Pratica maior to propose them again in the De regimine pregnantium, a gynaecological and pediatric work which was particularly significant because it was addressed to women. His intention was to disclose the expertise of the medicine for pregnant women and infants up to seven years, and for this reason, is written in the vernacular. 
organs of both men and women, magical remedies (chp. 2), and remedies to find out whether a woman claiming pregnancy is really pregnant (chp. 19).

Other passages are taken from John Anglicus' Rosa Anglica (fourteenth century). ${ }^{30}$ Once again, Codronchi opposes superstitious remedies and prayers used in the treatment of pain and hiccups. For example, chapter 3 of the third book prescribed to treat toothache by reciting the prayer "in the name of God and his Son Christ" and by writing sacred names on the patient's jaw. The same holds for Giovanni di Vigo's Practica copiosa in arte chirurgica ad filium Aloisium (1517) and Bernardo Gordonio's Practica medicinae (1303), in which Codronchi expurgates magical remedies against epilepsy, which involves the use of stones and prayers.

Codronchi also proposes the elimination of a chapter of Marco Gattinara's De curis aegritudinum (1542) — which is actually nothing more than a comment of the ninth book of the Liber medicinalis ad Almansorem by Rhazes-in which magical remedies for excessive nosebleed are recommended. ${ }^{31}$ Then, Codronchi deals with book 2 of Domenico Leoni's Ars Medendi, in which Leoni explains the power of succubus, incubus, the necromantic faculties of Merlin and insane love.

Lastly, the proposal to expurgate chapter 16 of Jean Fernel's De abdits rerum causis (1548) deserves particular attention. ${ }^{32}$ In the preface of the text, dedicated to the newly crowned Henry II of France, Fernel encourages the exploration of the Hippocratic statements concerning the 'divine aspects of diseases' (Forrester 2005, p. 119). He refers to the question of Hippocrates' Prognostica where physicians are encouraged to consider the possibility of divine elements in the disease before making a diagnosis (Thivel 1975). His intention is to propose a medicine which goes beyond the epistemic horizon of the ancient scholars. From Fernel's point of view, ancient medical science has been improved by the Christian doctrine. It is only through this reading that Hippocrates could be better understood, and specifically because occult causes play a role not only in medicine but also in the whole natural philosophy (Hirai 2005; Lavenia 2013). Fernel was part of a generation of scholars permeated by Renaissance naturalism who believed that magic could act both in physis and on physis. The rediscovery of Platonism and Hermeticism and the spread of Ficino's translation of the Corpus Hermeticum recreated a framework which embraced all the magical and astrological ancient wisdom and where Fernel's occult causes represented a legitimate part of natural philosophy. Moreover, such a framework represented an alternative to the materialistic naturalism of the physicians who read Galen through Avicenna. Not a rejection of Aristotelianism tout court, but the recovery of some peripatetic categories within the broader Ficino's spiritus mundi. (Walker 1972).

The discussion of classical themes of Aristotelian philosophy in the first part of Fernel's book prepares the ground for the central argument concerning the hidden causes of diseases displayed in the second part. From Fernel's Galenic point of view, ordinary diseases are the consequence of humoral imbalances, while occult diseases are described as "evils of the total substance" (Forrester 2005, p. 549; Deer Richardson 1985). From an Aristotelian perspective, these latter did not act on the humors of the body only, but on the body as a whole; accordingly, they do not cause a simple humoral imbalance but a complex symptomatology affecting the whole body. In contrast, venefical diseases are not only unmeasurable but also detectable. These occult remedies are distinguished from magical remedies that Fernel refuses to acknowledge, for only a rational and methodical analysis of occult faculties can be advocated. Fernel's intention was not to establish a magical or hermetical medicine or philosophy

30 It is John of Gaddensen (ca. 1280-1361) who was probably the first English court physician (Cholmeley 1912). The original Latin text was translated and circulated extensively in the Irish version and in manuscript form since the beginning of the fourteenth century, then was printed for the first time in Pavia in 1492. The Irish translation is not accurate and often presents interpolations of Bernardo Gordonio's Lilium medicinae. There were many re-editions of the work, including a handwritten Irish translation from 1450, and Codronchi refers to the last of these printed in Augsburg in 1595.

31 These included the bursa pastoris. The "shepherd's bag" is a plant with hemostatic and astringent properties mainly used to stop or calm the excessive menstrual flow.

32 "quamplurima recenset remedia superstitiosa, et fortasse magica nonnulla, quibus, ut ipse scritti, quamplurimi sanari morbi creditum est. a car. 277. ibi superstitiosum dico morbum comitialem etc. usque a car 279. inclusivè et in finem capitis". 
on the example of Ficino, but simply to solve those pathological questions that Aristotelian-Galenic medicine could not solve by appealing to occult causes.

Chapter 16 of Fernel's book, the one that Codronchi proposes to expurgate, deals with the actuality of supernatural diseases and diabolical possession. It reports the case of a young boy suffering from convulsions and strong and rapid shocks, apparently not associated with alterations of the mind or the senses. In fact, the boy's mind was healthy even during the fury of the convulsions. All the doctors who visited him diagnosed epilepsy caused by harmful vapors placed on the spine and spreading from the column to the limbs through the nerves, but the vapors did not reach the brain. Only after three months was the actual cause of the disease discovered: a demon presented himself by speaking Latin and Greek through the boy's voice, although the patient did not know Greek at all (Forrester 2005, pp. 652-55). Fernel briefly describes the powers of demons, how they enter bodies and afflict them in many ways by intervening either directly in the structures or by causing an imbalance of humors in the body. At least to that point, it does not seem that Fernel's discourse is in any way opposed to that of Codronchi. However, Fernel proceeds to explain that demons are responsible for all this, and since they belong outside nature, remedies against them will have to transcend the sensitive: among transcendent remedies, some are genuinely divine, others are magical. Moreover, superstitions occur not only in what transcends nature, but also in most natural remedies-such as when powers are attributed to herbs, plants, stones or metals, powers that are related neither to manifest qualities nor to their entire substance. Once again, Codronchi's concern is not related to the understanding of the hidden origin of diseases, but rather to their magical resolution. Therefore, Codronchi's attempt is to reaffirm once again the primacy of the physician in the therapeutic dimension.

Codronchi's proposals to the Congregation of the Index regarding the expulsion of medical works appears to be motivated by two sorts of reasons that proceed hand in hand. First, it should be noted that proposals mainly concern extracts from ancient and medieval texts which offer treatments for epilepsy and female illnesses. In the works listed by Codronchi the sacred disease is interpreted as similar to other common brain diseases. However, even when naturalized, epilepsy is cured with magical remedies and practices. Scribonius Largus treats epilepsy as a disorder of the head, along with headaches, dizziness and sinusitis; Alexander of Tralles also refers to epilepsy as a headache; Savonarola deals with epilepsy in the broader chapter on brain diseases; similarly, Domenico Leoni clarifies that 'the cause of epilepsy is in the proper essence in the brain' (Leoni 1583, f. 126). The therapies offered by these authors all involve magical remedies or religious means, such as the prayers proposed by Gordonius. In the sixteenth century, despite the rationalistic efforts of the followers of Hippocrates and Galen, the echo of the supernatural explanation of epilepsy had not yet subsided (Temkin 1971; Eadie and Bladin 2001). We could even suppose that such a supernatural explanation went through some sort of a revival in this period: in the European context of witch-hunting and diabolical obsession, the rational explanation of epilepsy was rejected in favor of an explanation which accounted for convulsion and momentary aphasia and which was compatible with diabolical possession.

To return to what Codronchi stated in the De morbis veneficis, superstitious activities are evil not only because they are contrary to God, but also because they are ineffective. In fact, such superstitious activities are not only based on an erroneous knowledge of the natural order of things, but they may also involve powers that a good Christian should never attempt to use. In addition, in the De morbis veneficis, Codronchi explains how peripatetic rationalism is to be philosophically rejected because it was incapable of explaining diseases caused by venefici. Hippocratic and Galenic science needed to be revised as well, inasmuch as they made exclusive reference to the principles of natural philosophy. ${ }^{33}$ Thus, on the one hand, the naturalization of epilepsy following the Hippocratic example would have

33 Codronchi (1595), ff. 21r-22: "[ . . . ] At Deus horum morborum causa esse non potest, nec caeteri morbi ita appellantur; ideo sequitur morborum hunc sacrum alia ratione dici. Malefici enim ac Magi (ut arbitror), Hippocratis tempore, quo rudes satis erant homines ut improbitates suas ac scelera tegerent imponebant plebi, hunc morbum esse divinitus dimissum: et divinis est remediis et expiationibus abolendum esse. Quae remedia et expiationes quoniam in cultum et venerationem 
totally emptied of meaning the whole analysis that Codronchi makes of demons and their powers. On the other hand, Codronchi is a physician and he cannot accept that a toothache could be cured with prayers, as suggested by John Anglicus. Therefore, Codronchi was caught between two medical orthodoxies which he despised: one which denied 'supernatural' causation, the other advocated for supernatural but magical cures.

For the same reason, it should come as no surprise that Codronchi's other major concern is women's disease. Codronchi had already expressed his opposition to Aristotelian and Galenic rationalist theories. His refusal then extends from the strictly medical field to the more general sixteenth-century paradigm concerning obstetrical and gynaecological pathologies, which had seen the galenic-paradigm totally overturned. If, for Galen, menstruation represented a sort of natural bloodletting, a purge against many pathologies and also a nourishment for the foetus, in early modern times the relationship between disease and menstruation was reversed, and menstrual blood, to which nefarious vapors are associated, was instead conceived as the cause of pathologies, able to infect others.

All the extracts presented by Codronchi in the list treat gynaecological and sexual problems with heterodox and typically magical methods. This aspect is not unusual, since female genital anatomy was fundamentally ill-understood until the end of the eighteenth century; as a consequence, the attribution of psychological and moral causes was typical of women's medical manuals. Medieval and early modern treatises inevitably took into account magical elements (Niccoli 2006; King 2007; Green 2008). The passages that Codronchi proposes to expurgate in the works of Priscianus, Falcucci and Savonarola are part of this context. It looks like Codronchi's anti-magical concerns are grounded in both medical—scientific - and religious principles. What Codronchi wants to eliminate from the textual medical culture is the part of medical production that admits the possibility of magical treatments and remedies, for, in the Italian context of the sixteenth and the seventeenth centuries, this would have meant legitimizing the work of folk healers, charlatans and magicians to whom the sick turned for help. These also included midwives to whom women appealed to not only during pregnancy and childbirth but also to solve any other gynaecological problem.

Another set of reason may concern the published editions of the works expurgated. It is certainly unlikely that Codronchi had direct access to the original copies of the works listed. Alexander Trallianus' work represented a fundamental text for the teaching of medicine throughout the Middle Ages, then, in the early modern age, it was translated from Greek to Latin and found a widespread audience in the territories of the German area. ${ }^{34}$ Furthermore, it is repeatedly mentioned by Girolamo Gabucini in the De comitiali morbo libri III and by Thomas Mouffet, an English Paracelsian physician; Myrepsius' book circulated thanks to the Greek-to Latin translation of Leonhart Fuchs, a well-known Lutheran physician and botanist and had been proposed as a model for the official pharmacopoeia by William Bullein in England. However, it is possible to suppose that all the ancient sources recorded by Codronchi had a single origin, namely the Medicae artis princeps published in Paris by Henri Estienne in 1567. The work is a summa of pharmacological notions elaborated over the centuries by combining the Greek and Latin traditions with Arab and Byzantine medicine. All these editions manifestly contained heterodox theses, were produced in German-speaking lands and were particularly widespread in Protestant countries. If Codronchi's source was actually Henri Estienne, we should not forget that the author was the son of Robert Estienne, the official royal printer under Francis I who was accused of heresy by the Sorbonne in 1547 for having translated the biblical texts. This aspect may not have gone unnoticed within Codronchi's project of ensuring not only medical but also political and religious orthodoxy.

To conclude, a parallel reading of the De morbis veneficis and of the list sent to the Congregation of the Index suggests that more than sincere spirituality, Codronchi's motivation exposes his intention

cacodaemonum cedebant: eorum auxilio malefici viri quamplurimos curabant. Vel curatos esse ex aliquo temporis intervallo demonstrabant".

34 The Strasbourg editions of 1549 edited by Gunther of Andernach was reprinted three times in Venice in 1552,1555 and 1573. The Basel edition of 1556, similarly edited by Andernach, was reprinted in Lyon in 1576. 
to emancipate medicine both from theology, with which he expects and hopes to form a dialectic, especially from that medical marketplace mostly composed of non-specialists. In effect, even in the De morbis veneficis, Codronchi appears to be in line with the Counter-Reformation policies and with the deepest Christian morality; the book simultaneously emphasizes the metaphysical and theological reality of demons and their power within the physical space, as well as the fundamental role of the physician in fighting them. Therefore, the aim is to establish an autonomous space for medicine, even if, for Codronchi, this happens within the field of theology and not outside it.

Demonology offers an opportunity to reaffirm the substantial common purpose of physicians and exorcists, and, at the same time, to emphasize the primary role of the physician in acting on the body. The only forward step medicine can take is before the under the aegis of ecclesia. For this reason, even if Codronchi insists that the physician must turn to the exorcist in case of devilish possession, as the devil actually represents an earthly expedient.

Funding: This research received no external funding.

Conflicts of Interest: The author declares no conflict of interest.

\section{References}

Aaron-Beller, Katherine, and Christopher Black, eds. 2018. The Roman Inquisition. Center versus Peripheries. Brill: Leiden.

Baldini, Ugo, and Leen Spruit, eds. 2009. Catholic Church and Modern Science. Documents from the Archives of the Roman Congregations of the Holy Office and the Index. Vol I: Sixteenth-Century Documents I-IV. Roma: Libreria Editrice Vaticana.

Bever, Edward. 2009. Witchcraft Prosecutions and the Decline of Magic. Journal of Interdisciplinary History 40: 263-93. [CrossRef]

Bianchi, Massimo Luigi. 1982. Occulto e manifesto nella medicina del Rinascimento: Jean Fernel e Pietro Severino. Atti e Memorie dell' Accademia Toscana di Scienze e Lettere 47: 183-248.

Biondi, Albano. 1981. La signora delle erbe e la magia della vegetazione. In Medicina, erbe e Magia. Cultura Popolare nell'Emilia Romagna. Milano: Silvana, pp. 185-204.

Biondi, Albano. 1994. Tra corpo e anima: medicina ed esorcistica nel Seicento (l'Alexícacon di Candido Brugnoli). In Disciplina dell'anima, Disciplina del corpo, e Disciplina della Società tra Medioevo ed età Moderna. Edited by Paolo Prodi. Bologna: Il Mulino, pp. 397-416.

Brambilla, Elena. 2006. La giustizia Intollerante. Inquisizione e Tribunali Confessionali in Europa (Secoli IV-XVIII). Roma: Carocci.

Brambilla, Elena. 2010. Corpi invasi e viaggi dell'anima. Santità, Possessione, Esorcismo dalla Teologia Barocca alla Medicina Illuminista. Roma: Viella.

Caciola, Nancy. 2003. Discerning Spirits. Divine and Demonic Possession in the Middle Ages. Ithaca and London: Cornell University Press.

Cameron, Euan. 2010. Enchanted Europe. Superstition, Reason and Religion, 1250-1750. Oxford: Oxford University Press.

Cholmeley, Henry Patrick. 1912. John of Gaddesden and the Rosa Medicinae. Oxford: Oxford Clarendon Press.

Clark, Stuart. 1997a. Demons and Disease. The Disenchantment of the Sick. In Illness and Healing Alternatives in Western Europe. Edited by Marijke Gijswijt-Hofstra, Hilary Marland and Haans de Waardt. London: Routledge, pp. 38-58.

Clark, Stuart. 1997b. Thinking with Demons. The Idea of Witchcraft in Early Modern Europe. Oxford: Clarendon Press.

Codronchi, Giovan Battista. 1591. De Christiana ac tuta Merenda Ratione. Ferarriae: Apud Benedictum Mammarellum.

Codronchi, Giovan Battista. 1595. De morbis Veneficis ac Veneficiis. Venetiis: Apud Franciscum de Franciscis.

Dall'Olio, Guido. 2001a. Tribunali vescovili, Inquisizione romana e stregoneria: I processi bolognesi del 1559. In Il piacere del testo. Saggi e studi per Albano Biondi. Edited by Adriano Prosperi. Roma: Bulzoni, pp. 63-82.

Dall'Olio, Guido. 2001b. Alle origini della nuova esorcistica. I maestri bolognesi di Girolamo Menghi. In Inquisizioni. Percorsi di Ricerca. Edited by Giovanna Paolin. Trieste: Edizioni dell’Università di Trieste, pp. 81-129. 
Dall'Olio, Guido. 2018. Esorcistica e caccia alle streghe. Il Compendio dell'arte essorcistica e il Malleus Maleficarum. In L'Inquisizione Romana, $i$ Giudici e gli eretici. Studi in onore di John Tedeschi. Edited by Andrea Del Col and Anne Jacobson Schutte. Roma: Viella, pp. 127-39.

De Blécourt, Willem. 1994. Witch Doctors, Soothsayers and Priests. On Cunning Folk in European Historiography and Tradition. Social History 19: 285-303.

Deer Richardson, Linda. 1985. The Generation of Disease. Occult Causes and Disease of the Total Substance. In The Medical Renaissance of the Sixteenth Century. Edited by Andrew Wear, Roger French and Iain M. Lonie. Cambridge: Cambridge University Press.

Di Simplicio, Oscar. 2005. Autunno della Stregoneria. Maleficio e Magia nell'Italia Moderna. Bologna: Il Mulino.

Donato, Maria Pia. 2009. Les doutes de l'Inquisiteur. Philosophie naturelle, censure et théologie à l'époque moderne. Annales HSS 1: 15-43. [CrossRef]

Donato, Maria Pia. 2019. Medicine and the Inquisition in the Early Modern World. Leiden: Brill.

Dragon, Tristan. 2006. La doctrine des qualités occulte dans le De Incantationibus de Pomponazzi. Revue de Métaphysique et de Morale 3: 1-20.

Duni, Matteo. 1999. Tra Religione e magia. Storia del prete Modenese Guglielmo Campana (1460?-1541). Firenze: Olschki.

Duni, Matteo. 2012. I dubbi sulle streghe. In I Vincoli della Natura. Magia e Stregoneria nel Rinascimento. Edited by Germana Ernst and Guido Giglioni. Roma: Carocci, pp. 203-21.

Duni, Matteo. 2016. Doubting Witchcraft: Theologians, Jurists, Inquisitors during the Fifteenth and Sixteenth Centuries. Studies in Church History 52: 203-31. [CrossRef]

Eadie, Mervin J., and Peter F. Bladin. 2001. A Disease Once Called Sacred: A History the Medical Understanding of Epilepsy. Eastleigh: John Libbey.

Ernst, Germana. 1991. Dalla bolla "Coeli et terrae" all' "Inscrutabilis". L'astrologia tra natura, religione e politica nell'età della Controriforma. In Ead. Religione, Ragione e Natura. Ricerche su Tommaso Campanella e il tardo Rinascimento. Milano: Franco Angeli, pp. 255-79.

Ferri, Andrea. 1997. I Gesuiti ad Imola e le Scuole Cittadine nel Complesso di Sant'Agata, 2 Voll. Castel Bolognese: Bologna University Press.

Ferri, Andrea, ed. 2001. L'Inquisizione Romana in Diocesi di Imola. Inventario del fondo Inquisitoriale presso l'Archivio Diocesano di Imola. Imola: Diocesi di Imola.

Flint, Valerie. 1999. The Demonization of Magic and Sorcery in Late Antiquity. Christian Redefinition of Pagan Religions. In Witchcraft and Magic in Europe. Edited by Bengt Ankarloo and Stuart Clark. Vol 2: Ancient Greece and Rome. London: Bloomsbury Publishing PLC, pp. 277-348.

Formisano, Marco. 2004. The "Natural" Medicine of Theodorus Priscianus. Between Tradition and Innovation. Philologus 148: 126-42. [CrossRef]

Forrester, John, ed. 2005. Jean Fernel's On the Hidden Causes of Things. Forms, Souls and Occult Diseases in Renaissance Medicine. Leiden and Boston: Brill.

Fragnito, Gigliola. 1997. La bibbia al rogo. La Censura Ecclesiastica e i Volgarizzamenti della Scrittura (1471-1605). Bologna: Il Mulino.

Frajese, Vittorio. 1997. Nascita dell'Indice. La Censura Ecclesiastica dal Rinascimento alla Controriforma. Brescia: Morcelliana.

Gentilcore, David. 1998. Healers and Healing in Early Modern Italy. Manchester and New York: Manchester University Press.

Gentilcore, David. 2006. Medical Charlatanism in Early Modern Italy. Oxford: Oxford University Press.

Ginzburg, Carlo. 1966. I benandanti. Ricerche sulla Stregoneria e sui culti agrari tra Cinquecento e Seicento. Einaudi: Torino.

Ginzburg, Carlo. 1989. Storia Notturna. Una Decifrazione del Sabba. Einaudi: Torino.

Green, Monica. 1994. The Re-Creation of Pantegni, Practica, book VIII. In Constantin the African and Ali ibn al-Abbas al-Magusi. The Pantegni and Related Text. Edited by Charles Burnett and Danielle Jaquart. Leiden: Brill, pp. 121-60.

Green, Monica. 2008. Making Women's Medicine Masculine. The Rise of Male Authority in Pre-Modern Gynecology. Oxford: Oxford University Press.

Heintz, Florent. 1997. Simon "le Magicien". Actes 8, 5-25 et l'accusation de magie contre les Prophètes Thaumaturges dans l'antiquité. Paris: Gabalda. 
Herzig, Tamar. 2008. Bridging North and South. Inquisitorial Networks and Witchcraft Theory on the Eve of the Reformation. Journal of Early Modern History 12: 361-82. [CrossRef]

Herzig, Tamar. 2017. Fear and Devotion in the Writings of Heinrich Institoris. In Emotions in the History of Witchcraft. Edited by Laura Kounine and Michael Ostling. Houndmills: Palsgrave Macmillan, pp. 19-35.

Hirai, Hiro. 2005. Alter Galenus. Jean Fernel et son interprétation platonico-chretienne de Galien. Early Science and Medicine 10: 1-35. [CrossRef]

Jouanna, Jaques. 2011. Médecine rationnelle et magie: Le statut des amulettes et des incantations chez Galien. Revue des Études Greques 124: 47-77. [CrossRef]

King, Helen. 2007. Midwifery, Obstetrics and the Rise of Gynaecology. The Uses of a Sixteenth-Century Compendium. Aldershot: Ashgate.

Largus, Scribonius. 2016. Les Compositions Médicales. Edited by Joëlle Jouanna-Bouchet. Paris: Les Belles Lettres.

Lavenia, Vincenzo. 2005. "Tenere i Malefici per cosa vera". Esorcismi e censura nell'Italia moderna. In Dal Torchio alle Fiamme. Inquisizione e Censura. Edited by Vittoria Bonani. Salerno: Biblioteca Provinciale di Salerno, pp. 129-72.

Lavenia, Vincenzo. 2011. Possessione demoniaca, Inquisizione ed esorcismo in età moderna. Il caso italiano (secoli XVI-XVII). In Devozioni, Pratiche e Immaginario Religioso. Espressioni del Cattolicesimo tra 1400 e 1850. Edited by René Miller and Roberto Rusconi. Roma: Viella, pp. 203-30.

Lavenia, Vincenzo. 2013. La medicina dei diavoli: Il caso italiano, secoli XVI-XVII. In Médicine et Religion. Collaborations, Compétitions, Conflits (XIIe-XXe Siècle). Edited by Maria Pia Donato, Luc Berlivet, Sara Cabibbo, Raimondo Michetti and Marilyn Nicoud. Roma: École française de Rome, pp. 163-94.

Leoni, Domenico. 1583. Ars Medendi. Humanos Particularesque Morbos a Vertice Usque ad pedes, quae ob Lucidiorem Doctrine in tres Dividir Sectiones. Bononiae: Apud Ioannem Rossium.

Levack, Brian. 2006. The Witch-Hunt in Early Modern Europe. Edinburgh: Pearson Longman. First published 1987.

Machielsen, Jan. 2011. Thinking with Montaigne. Evidence, Skepticism and Meaning in Early Modern Demonology. French History 25: 427-52. [CrossRef] [PubMed]

Machielsen, Jan. 2015. Martin Delrio. Demonology and Scholarship in the Counter-Reformation. Oxford: Oxford University Press.

Maggi, Armando. 2001. Satan's Rhetoric. A Study of Renaissance Demonology. Chicago: University of Chicago Press. Maggi, Armando. 2006. In the Company of Demons. Unnatural Beings, Love, and Identity in the Italian Renaissance. Chicago: Chicago University Press.

Mammola, Simone. 2012. La Ragione e l'incertezza. Filosofia e Medicina nella Prima età Moderna. Milano: Franco Angeli.

Marasco, Gabriele. 2011. L'accusa di magia e i cristiani nella tarda antichità. Augustinianum 51: 367-421. [CrossRef]

Marcus, Hannah. 2018. The Mind of the Censor: Girolamo Rossi, a Physician and Censor for the Congregation of the Index. Early Science and Medicine 23: 14-33. [CrossRef]

Mayer, Thomas. 2014. The Roman Inquisition on the Stage of Italy, c. 1590-640. Philadelphia: University of Pennsylvania Press.

Mazzini, Giuseppe. 1924. Di Battista Codronchi Medico e filosofo Imolese: 1547-628. Terni: Stabilimento Altarocca.

Minuzzi, Sabrina. 2016. Sul filo dei Segreti. Farmacopea, libri e Pratiche Terapeutiche a Venezia in età Moderna. Milano: Unicopli.

Monter, William. 2006. Geography of the Witch-Hunts. In The Encyclopedia of Witchcraft. The Western Tradition. Edited by Richard M. Golden. Santa Barbara: ABC Clio, pp. 412-16.

Niccoli, Ottavia. 2001. L'esorcista prudente. Il Manuale Exorcistarum ac Parochorum di Fra Candido Brugnoli da Sarnico. In Il Piacere del Testo. Saggi e Studi per Albano Biondi. Edited by Adriano Prosperi, Massimo Donating and Gian Paolo Brizzi. Roma: Bulzoni, pp. 193-215.

Niccoli, Ottavia. 2006. Maternità critiche. Donne che partoriscono gli inizi dell'età moderna. Studi Storici 47: 463-79.

Pomata, Gianna. 1998. Contracting a Cure. Patients, Healers and the Law in Early Modern Bologna. Baltimore and London: John Hopkins University Press. First published 1994.

Pomata, Gianna. 1999. Practicing between Earth and Heaven: Women Healers in Seventeenth-Century Bologna. Dynamis: Acta Hispanica ad Medicinae Scientiarumque Historia Illustrandam 19: 119-43.

Prevideprato, Massimo. 1992. Tu hai Renegà la fede. Stregheria ed Inquisizione in Valcamonica e nelle Prealpi Lombarde dal XV al XVII Secolo. Brescia: Vannini. 
Prosperi, Adriano. 2006. I Tribunali della Coscienza. Inquisitori, Confessori, Missionari. Torino: Einaudi. Ricci, Saverio. 2008. Inquisitori, Censori, Filosofi sullo Scenario della Controriforma. Roma: Salerno.

Romeo, Giovanni. 1990. Inquisitori, Esorcisti e Streghe nell'Italia della Controriforma. Firenze: Sansoni.

Romeo, Giovanni. 2002. L'Inquisizione nell'Italia Moderna. Roma and Bari: Laterza.

Romeo, Giovanni. 2005. Altre Inquisizioni. Vescovi, Congregazione del Sant'Ufficio e medici ebrei nell'Italia della Controriforma. In Scritti in onore di Alberto Tenenti. Edited by Pierroberto Scaramella. Napoli: Bibliopolis, pp. 513-35.

Romeo, Giovanni. 2008a. Inquisitori domenicani e streghe in Italia tra la metà del Cinquecento e i primi decenni del Seicento. In I Domenicani e l'Inquisizione Romana. Edited by Carlo Longo. Roma: Istituto Storico Domenicano, pp. 309-44.

Romeo, Giovanni. 2008b. Inquisizione, Chiesa e stregoneria nell'Italia della Controriforma: nuove ipotesi. In «Non Lasciar Vivere la Malefica». Le Streghe nei Trattati e nei Processi (Secoli XIV-XVII). Edited by Dinora Corsi and Matteo Duni. Firenze: Firenze University Press, pp. 53-65.

Schleiner, Winfried. 1995. Medical Ethics in the Renaissance. Washington: Georgetown University Press.

Schwedt, Herman H. 2013. Die Anfänge der Römischen Inquisition. Kardinäle und Konsultoren 1542 bis 1600. Freiburg: Herder.

Sluhovsky, Moshe. 2007. Believe Not Every Spirit. Possession, Mysticism and Discernment in Early Modern Catholicism. Chicago: Chicago University Press.

Tavuzzi, Michael. 1997. Prieras. The Life and Works of Silvestro Mazzolini da Prierio (1456-527). Durham and London: Duke University Press.

Tavuzzi, Michael. 2007. Renaissance Inquisitors. Dominican Inquisitors and Inquisitorial Discrtict in Northern Italy, 1474-527. Leiden and Boston: Brill.

Tedeschi, John. 1990. Inquisitorial Law and the Witch. In Early Modern European Witchcraft. Centre and Peripheries. Edited by Bengt Ankarloo and Gustav Henningsen. Oxford: Clarendon, pp. 83-118.

Temkin, Owsei. 1971. The Falling Sickness. A History of Epilepsy from the Greeks to the Beginnings of Modern Neurology. Baltimore: The John Hopkins Press.

Thivel, Antoine. 1975. Le "divin" dans la Collection Hippocratique. In La Collection Hippocratique et son rôle dans l'Histoire de la Médecine. Leiden: Brill, pp. 57-76.

Valente, Michaela. 2003. Johann Wier. Agli albori della Critica Razionale dell'occulto e del Demoniaco nell'Europa del Cinquecento. Firenze: Olschki.

Valente, Michaela. 2008. La critica della caccia alle streghe da Johann Wier a Balthasar Bekker. In «Non Lasciar Vivere la Malefica». Le Streghe nei Trattati e nei Processi (secoli XIV-XVI). Edited by Dinora Corsi and Matteo Duni. Firenze: Firenze University Press, pp. 67-82.

Valente, Michaela. 2012. "Conoscere a fondo le pessime arti de' maliardi per potersene guardare e difendere". Sulla censura di alcuni trattati demonologici. Dimensioni e Problemi della Ricerca Storica, 171-92. [CrossRef]

Valente, Michaela. 2015. Superstitione, heresia e ignorantia. Teoria e prassi inquisitoriale in alcuni casi di maleficia. In Prescritto e Proscritto. Religione e Società nell'Italia Moderna (Secoli XVI-XIX). Edited by Andrea Cicerchia, Guido Dall'Olio and Matteo Duni. Roma: Carocci, pp. 65-83.

Walker, Daniel Pickering. 1972. The Ancient Theology. Studies in Christian Platonism from the Fifteenth to the Eighteenth Century. London: Cornell University Press.

Weber, Domizia. 2011. Sanare e Maleficiare. Guaritrici, Streghe e Medicina a Modena el XVI Secolo. Roma: Carocci.

Young, Francis. 2016. A History of Exorcism in Catholic Christianity. Cambridge: Palsgrave MacMillan.

Zambelli, Paola. 1996. L'ambigua Natura della Magia. Filosofi, Streghe, riti nel Rinascimento. Venezia: Marsilio.

Zanelli, Giuliana. 1992. Streghe e Società nell'Emilia e Romagna tra Cinquecento e Seicento. Ravenna: Longo.

Zanier, Giancarlo. 1975. Ricerche sulla Diffusione e Fortuna del De Incantationibus di Pomponazzi. Firenze: La Nuova Italia.

(C) 2019 by the author. Licensee MDPI, Basel, Switzerland. This article is an open access article distributed under the terms and conditions of the Creative Commons Attribution (CC BY) license (http://creativecommons.org/licenses/by/4.0/). 


\title{
Notes on the Nature of Beliefs in Witchcraft: Folklore and Classical Culture in Fifteenth Century Mendicant Traditions
}

\author{
Fabrizio Conti \\ Department of History and Humanities, John Cabot University, 00165 Rome, Italy; faconti@johncabot.edu
}

Received: 11 August 2019; Accepted: 12 October 2019; Published: 15 October 2019

\begin{abstract}
Witchcraft is a varied historical phenomenon with changing sociocultural aspects according to the times and the places considered. Nonetheless, it is possible to trace the different cultural substrata giving shape to witch-beliefs in order to shed light on their process of amalgamation. The aim of this study is to show how the folkloric and the Classical literary motives were intertwined in the fifteenth century by figures lauded as the high intellectuals of the time, Franciscan and Dominican preachers and inquisitors, to produce a coherent and multifaceted picture of witchcraft-related beliefs. By putting some of the most significant sources that I have analyzed in my monograph Witchcraft, Superstition, and Observant Franciscan Preachers in relation to others that I have not considered before composed by the same or different authors, my aim is to show how this process of combination of various cultural traditions gave shape to the creation and the understanding of the witchcraft phenomenon. Furthermore, I also intend to highlight how the at times contradictory views concerning witch-beliefs, pointing either to realistic or to skeptical stances, are related to specific declensions of those different traditions on the part of the friars.
\end{abstract}

Keywords: witchcraft; Franciscan and Dominican friars; magic; folklore; classical culture; religious history

Witchcraft is a multifaceted cultural phenomenon with its nature, causes, and outcomes bound to a high degree of variation and fluidity according to the geographical and the chronological boundaries considered. ${ }^{1}$ The origin and the peculiar cultural substrata shaping witch-beliefs can, however, be reconstructed in detail to shed light on their intellectual formative processes. My aim here is to show how two of the main cultural substrata behind the construction of witch-beliefs, the folkloric and the Classical literary motives, were intertwined in the fifteenth century by Mendicant preachers and inquisitors to produce a coherent and multifaceted picture of witchcraft-related beliefs. By relating some of the most meaningful sources that I have analyzed in my monograph Witchcraft, Superstition, and Observant Franciscan Preachers (2015) to others that I have not analyzed before, my aim is twofold. I aim to show how this process of amalgamation of various cultural traditions gave shape to the creation and the understanding of the witchcraft phenomenon, and to highlight how the at times contradictory views concerning witch-beliefs pointing either to realistic or to skeptical stances, are associated with specific declensions of those different traditions on the part of the friars. In other words, I shall show how and with what purpose the texts of the friars recall and reuse both folkloric and classical traditions in dealing with witch-beliefs. ${ }^{2}$

The myth of witchcraft is not a standalone phenomenon, one disconnected from a wider, and at the same time, specific context. Through their assessment of people's level of adherence to Christian faith,

\footnotetext{
Cf. (Kieckhefer 2013, 2006; Barry and Davies 2007; Briggs 1996).

See (Conti 2015).
} 
according to the rules of Scholastic theological models, the Mendicant friars collected and elaborated on elements that would become a constitutive part of beliefs in witchcraft. In this regard, those friars often dealt with witch-beliefs as part of their concerns over superstition-this latter being the domain opposing official Christian religious practices-as well as in the context of pastoral care, as I have shown in the case of fifteenth-century Milanese Franciscan friars ${ }^{3}$ The teachings of the confessor as well as those of the preacher show how the world of superstition is vast. As the renowned Dominican preacher Girolamo Savonarola (d. 1498) shows in his Eruditorium confessorum, a handbook for the instruction of confessors, superstition opposes religion, and it includes specific categories of practitioners of witchcraft among those dealing with other classes of magic:

The sinner has to be interrogated about the superstitious cult, which acts against religion. [... ] The idolaters, necromancers, evil doers (malefici), sorceresses (mulieres incantatrices), and whoever else exhibit cult to the devil, they all sin against that [religion] in a very serious way [... ]. And similarly [sin] the enchanters, diviners, and those who say to be able to find stolen objects through various superstitions as well as those who wear amulet scrolls hanged on their neck $[\ldots]{ }^{4}$

Malefici and mulieres incantatrices certainly belong within the domain of witchcraft. While the term maleficus can be employed in a general way to indicate the one who conducts evil, in his Libellus against magicians the Dominican Isidoro Isolani (d. 1528) includes witches (strigae) as part of the malefici category. ${ }^{5}$ The women who practice sorcery (mulieres incantatrices) offer the category of superstition an even more precise orientation towards witch-beliefs, leading to the construction of the stereotype of the witch practitioner typically being female. Within this context, folklore and classical culture emerged as the two primary domains from which the constitutive elements of beliefs in witchcraft will be taken and assembled.

In the record of superstitions that is part of the Sermones discipuli de tempore published in 1418 by the German Dominican preacher Johannes Herolt (d. 1468), known as the Discipulus, the friar gives an interesting account of beliefs seemingly referring to pre-Christian folkloric traditions. In particular, in his Sermon 41 for the second Sunday of Lent titled "On the twenty-four types of men who falsify faith," Herolt enlists a number of beliefs and behaviors in opposition to the Christian faith, twenty-one of which are considered to be superstitions. ${ }^{6}$ Some of these elements concern the domain of divination, such as casting lots, the one of enchantment, such as casting spells, or that of magic, such as putting together love potions. Other elements pertain to superstitious attitudes called vanae observationes that Herolt, as all the other friars, generally consider with leniency, including observing dreams or observing the course of the moon and the sun. Other beliefs, on the contrary, are of much greater concern for the friar. Above all, the vetulae or old women who can make a woman sterile or provide advice on how to get rid of a fetus, as well as those women who enchant people and beasts, fall under the suspicion of showing a diabolic attitude endangering life in all its forms.

It had been most notably the belief in the train of the goddess Diana and the host of the dead as related by Herolt to catch the interest of scholars. The German friar develops a rather different version of the well-known witchcraft mythology centered on the ludus Dianae or the "Game of Diana," which relates to the tenth century canon Episcopi. Through its successive redactions by Regino of Prüm's De ecclesiasticis disciplinis of 906, Burchard of Worm's Decretum, and later on, Gratian's Decretum, the canon

3 On the weight of tradition and the role of superstition for the development of witchcraft cf.: (Bailey 2013); for the Milanese case see: (Conti 2011, pp. 62-91; Conti 2016, pp. 201-13).

4 Interrogandus est etiam peccator de superstitioso cultu qui est contra religionem. [ ... ] Peccant etiam contra hoc gravissime idolatre, necromantici, et malefici, et mulieres incantatrices et quicumque alii qui exhibentes cultum diabolo [ .... ]. Et ideo incantatores, et divinatores, et qui dicunt se invenire furta per varias superstitiones, et portantes brevia ad collum [ ... ]: (Savonarola 1510) f. [E Vr].

5 (Isolani 1506). Cf.: (Conti 2015, pp. 225-26).

6 (Herolt 1497) Sermon 41, fols hi ${ }^{\mathrm{vb}}-$ hiiii $^{\mathrm{ra}}$. 
Episcopi, mistakenly believed as issued at the Council of Ancyra of 314, pointed to those deluded women who believe they go about at night in the train with the goddess Diana (or with Herodias according to other redactions) on the backs of animals:

It is also not to be omitted that some wicked women, who have given themselves back to Satan and been seduced by the illusions and phantasms of demons, believe and profess that, in the hours of night, they ride upon certain beasts with Diana, the goddess of the pagans, and an innumerable multitude of women, and in the silence of the night traverse great spaces of earth, and obey her commands as of their lady, and are summoned to her service on certain nights. [... ] Such phantasms are imposed on the minds of infidels not by the divine but by the malignant spirit. ${ }^{7}$

Herolt connects this mythology to the world of the dead, as opposed to the original text of Episcopi. This separates his text from the several other authors who elaborate on the same myth without making such an association. ${ }^{8}$ The Dominican preacher writes:

The nineteenth [in this list] are those who believe that Diana goes about at night with her army through great distances. Similarly, some at night prepare the table and uncover the vessels so that the souls of the dead should fill them and bring them every fortune. ${ }^{9}$

The term army (exercitus) employed by the German preacher while pointing to belief in the night train of Diana travelling through the space of many lands, refers to the "furious horde" of the dead, thus apparently merging the myth of Diana with that of the army of the dead of Germanic origin. This was later connected to Unholda, the demonized and witch-like version of the goddess Holda, originally linked to the idea of bounty. The positive, original belief connected to this mythology is proven by the fact that, as Herolt writes, at night some people prepare tables and leave the pots open so that the souls of the deceased that are part of the army of Diana can fill them and make the households rich. The core of this belief rests on the idea of bounty and fortune brought about by those ghostly entities to the houses they visit, constituting an interesting opening towards the vast and foggy land of folkloric or popular beliefs.

As it is known, belief in supernatural travelers of female appearance and good inclination, visiting houses at night and being known as bonae res or "good things," enjoys a rather rich written tradition in medieval literature. Both William of Auvergne's (d. 1249) dominae nocturnae travelling in the train of a female figure whom he calls Lady Abundia and Satia, and the Dame Abonde of the late thirteenth-century Roman de la Rose show a clear link with the idea of prosperity. Stephen of Bourbon (d. 1261) as well as Vincent of Beauvais (d. 1264) link the "good women" to Diana (and Herodias) and the mulieres of the canon Episcopi, thus highlighting the interconnections between folkloric and literary domains. Such "good ladies," potentially dangerous entities themselves, had more harmful counterparts in the vast array of sorcerers roaming around with them such as the estries mentioned in the Roman de la Rose, and especially those evil nightly entities known as striges or lamiae which can shapeshift and murder children.

These latter beliefs are about entities coming from the Greco-Roman tradition. Lamiae were modeled on the Lamia of the Greek mythology, the beautiful Lybian princess and former mistress of

7 Illud etiam non est omittendum, quod quaedam sceleratae mulieres retro post satanam conuersae, daemonum illusionibus et phantasmatibus seductae, credunt se et profitentur nocturnis horis cum Diana paganorum dea et innumera multitudine mulierum equitare super quasdam bestias, et multa terrarum spacia intempestae noctis silentio pertransire, eiusque iussionibus uelut dominae obedire, et certis noctibus ad eius servicium euocari. [ . . . ] non a diuino sed a maligno spiritu talia phantasmata mentibus infidelium irrogari: (Regino of Prüm 1880); for the English translation of the Canon see: (Kors and Peters 2001, pp. 61-63).

8 See: (Ginzburg 1991, pp. 101-3).

9 Deciminoni sunt qui credunt quod Diana cum exercitu suo de nocte ambulet per multa spatia. Item aliqui de nocte preparant mensam et vasa discoperiunt ut manes debeant illa replere et ipsis hominibus fortunium prebere: Herolt, Sermones discipuli, Sermon 41, fol. hiiiir ${ }^{\text {ra }}$. See: (Conti 2015, p. 265). 
Zeus, who would later become a monster murdering young children. This is paralleled in near-eastern Lilith, their counterpart in the recurrent ancestral fear of child-killing demons. ${ }^{10}$

The Sicilian donni di fuora or the "ladies from outside" studied by Gustav Henningsen, represent the example of "good women" who mediated between the world of the humans and that of the fairies. These testify to the proximity to a mythology centered on joyful, dancing, and festive processions of fairies bringing food and prosperity to the houses they visit. That of the donni is a specific case of folkloric taste, having nothing to do with diabolic witchcraft, notwithstanding the attempt of the Spanish inquisition to merge the two traditions into one single pattern, just as it would happen with the Benandanti studied by Carlo Ginzburg. ${ }^{11}$ We cannot detect any diabolical traits in the accounts of the gatherings of the Sicilian ladies and in their entering the houses at night, as one woman joining them declared: "When they went into the houses it was like a wind, and they opened the chests and dressed themselves up in the clothes they found, and they played the tambourine and the lute and sang very sweetly." 12

It is in the interpretative efforts of the inquisition as well as in the texts of the preachers that the evolution from a mythology connected to joy and bounty can be seen taking up its diabolical connotation. This is often characterized by the idea of an inversion of Christian faith. Often the stance of the authors concerning these beliefs can vary within the context of belief in the ludus Dianae, from which the stereotype of the witches' Sabbath emerged.

The exemplum of the young girl from Ivrea told by the Milanese Observant Franciscan friar Bernardino Busti plays a particularly meaningful role in this context. According to the preacher, a young woman was convinced by a vetula, a wicked old lady, to join her at the Game of Diana (ludus Dianae). According to the folklore, this was a joyful event and closely linked to the history and mythology prevalent in the community. In her case, however, there is a condition. As the friar highlights, in order to take part in the game the girl is required to renounce her Christian faith:

A certain girl was often urged by a diabolical little old lady to go with her to the Game of Diana, after she had once said to her that she had never seen nor experienced such delights, and at last agreed to go. When the old lady told her that in order to participate in those sights and pleasures she would have to renounce the Christian faith, baptism and all the sacraments of the Church, she did all that. ${ }^{13}$

The friar goes on telling how the two women, the young girl and the diabolical old lady, went to a "wonderful hall covered with silk and filled with pleasant fragrances" where they engaged in joyful dances in the company of handsome young men dressed in golden and silver clothing. This went on until disgusted by the behavior of the vetula, the girl uttered the name of Jesus, and the entire ludus suddenly disappeared, leaving the young woman alone, right in the same place where she was before embarking on the experience, as she afterwards told to her confessor. As I have shown in my book, along with the new, diabolical connotation of the ludus Dianae, a development in the intellectual stance of the Milanese Franciscan friars about the nature of these beliefs takes place with an approach steadily leading to skepticism about their reality. That follows a line already expressed by Johannes Nider's (d. 1438) well-known exemplum concerning the vetula dementata (deluded old little woman) who accepted to demonstrate her ability to be carried through the air on a night ride with Diana to a Dominican friar. While the woman experienced she was flying, the friar, however, could just see

10 See: (Diodorus 2000, pp. 237-85); (Diodorus 2002, pp, 251-55); Cf.: (Montesano 2018, pp. 30 ff., 110-21; Paule 2018, pp. 65-74).

11 (Henningsen 2001, pp. 191-215; Ginzburg 1992).

12 (Henningsen 2001, p. 199)

13 Quedam iuvenis sepius incitata a quadam vetula diabolica ut ad ludum Diane secum pergeret, cum ei semel inter alia diceret quod numquam talia solatia viderat nec habuerat, tandem consensit. Cumque illi vetula diceret quod talibus spectaculis et consolationibus interesse non poterat nisi fidei christiane et baptismo atque omnibus sacramentis ecclesie renunciaret, illa omnia fecit: (Busti 1498, Sermon 16, fol. 129 ${ }^{\text {rbva }}$ ). Text in (Conti 2015, pp. 273-74). 
her falling asleep in the bowl where she had sat after having rubbed herself with some ointments and apparently having convulsions during her self-induced "demonic dreams."14

Along this line, those who visit the houses at night are not always described as fairies, but are accused of being evil women, specifically vetulae, according to a growing stereotypical association of witches with old women. These are women who can turn into other species, especially cats (shapeshifting being a feature that these evil beings share with the harmless fairies) in order to better penetrate into houses, which they can enter even through closed doors, to bring harm to babies placidly sleeping in their cradles. Still with a skeptical stance, the Observant Franciscan Antonio da Vercelli describes this belief discharging the women from perpetrating those actions, and granting sole responsibility onto the devil: "As what is seen under the shape of a cat is simply the devil himself, whom in the shape of an old woman or a cat kidnaps and murders babies in the cradle." 15 In order to discharge the accused women from the accusations, Antonio agrees that even in the case that something concrete happens, it is not due to the action of the woman allegedly involved but due to the devil.

Antonio elaborates further on the problem of the reality of this witch-belief by denying that the wounds one might detect on the bodies of a vetula should be considered the result of a physical altercation between the parents and the vetula and therefore the proof that she was a witch visiting homes at night:

On whether the blow truly leaves traces on the body of the little old lady, or in other words, whether such a wound is really imprinted on her, I say that this can happen in three ways. First, in a natural way, due to fact that the old woman may have injured herself by falling; second, this can happen due to strong imagination, as a punishment for her sins, as she believes of being part of the followers of Herodias or Diana, and to go about fascinating babies [so that] such wounds can be found on her as all this imagination makes her to fall; third, as the devil himself can injure the woman, with the permission of God, to punish her for her sins, and from all this she is convinced of being beaten or of killing the babies. To this you can add, if you want, a forth possibility: since the devil can deceive the eyesight of several people by making the little old lady seem that she was beaten, while she was not. ${ }^{16}$

The only real element, according to the preacher, is the illusion and that is the reason for the wounds one can find on the bodies of those vetulae erroneously considered to be witches. There are three possible causes for the wounds detected on the women as Antonio states: the first is the most common and it rests on the possibility that the women could have simply fallen during the day. The second can be the power of the imagination of the vetula concerning the reality of her travels along with Diana or Herodias, an imagination that can generate real falls. The last is a supernatural type of possibility, when with the permission of God the devil harms the old, wicked woman to punish her for her sins and she becomes convinced of having been beaten or performing her murderous acts on the babies. Here Antonio seems to elaborate further on an issue already addressed by Bernardino da Siena, when he points out that "the devil makes it seem to that evil woman that she shapeshift into a cat and go around bewitching. However, she remains in her bed. These are illusions of the devil to deceive

14 See: (Chène 1999, pp. 134-36). Cf.: (Klaniczay 2008, pp. 63-64).

15 Illud quod videtur in forma gatte simpliciter est ipse demon in specie vetularum vel musipularum pueros de cunabulis et lecto rapiens et occidens: (Antonio da Vercelli 1492, Sermon 45, fol. 329 ${ }^{\mathrm{vab}}$ ). Text in (Conti 2015, p. 279).

16 Quod autem realiter in persona vetule percussio facta remaneat, seu tale vulnus vetule imprimatur, dico quod hoc triplici respectu euenire potest. Primo naturaliter, ex casu ut puta dum cadendo tale vulnus recepisset. Secundo, hoc potest accidere ex vehementi ymaginatione in penam peccati, quia dum talis vetula ex comitibus se fore credit Herodiadis vel Diane, et credit se in ymaginatione esse ad rapiendum pueros, tale vulnus in ea factum remanet pro eo quod vehemens ymaginatio plerumque facit casum suum. Tertio, dicas quod permittente Deo in penam peccati diabolus sibi tale vulnus infligit ex quo ipsa credit se esse ad actum illius percussionis seu occisionis pueri. Adde si vis et quartum responsum quia plerunque diabolus potest deludere oculos videntium, ut talis vetula videatur percussa, cum tamen percussa non sit: (Antonio da Vercelli 1492, Sermon 45, fol. 329vab). 
people!"17 According to Bernardino, it is just the devil who wants to deceive people, to make it seem to the woman that she shapeshifted into a cat and went around bewitching. All while the truth is that she remains in her bed. The power of imagination, one might say.

Friars decry the belief in metamorphosis or the ability of humans to shapeshift into different species, as a diabolic illusion. To prove this point, Roberto da Lecce refers to examples of humans transformed into animals by magical or divine tricks in Classical myth and literature, primarily through the auctoritas of Augustine of Hippo, whose skeptical stance Roberto adopts to sustain his own view on this matter. Thus, the transformation of the companions of the Thracian hero Diomedes into birds "in the fashion of big geese" ("a modo de grosse oche"), that of Ulysses' companions into beasts by the "beautiful, evil, and lecherous" ("bella, malefica, e meretrice") Circe, and Lucius transformed into an ass by the mistake of the witch's servant Fotis in Apuleius' The Golden Ass, are all cases that, according to Roberto, participate in making belief in shapeshifting unrealistic, if not ridiculous. ${ }^{18}$

The belief - of folkloric taste - concerning the night visits of fairies into the homes not only had a completely harmless scope but also a positive one in bringing prosperity, joy, and fun to the babies living in the house. Such a belief eventually shifted into the one in old women changing shape in order to better sneak into the houses and murder the babies sleeping in their rooms. This is a shift from prosperity to its negation, and from life to death: that was the true sense of any witchcraft for those communities. The interesting point besides the evident shift in the meaning and the interpretation of these beliefs seems to be the skeptical view developed in the writings of those friars. There are, of course, discordant voices about this in the coeval sources and different approaches were always possible. The case of the condemnation by such an inquisitor as the Dominican Heinrich Kramer of "those dangerous and unlearned preachers" ("periculosi et indocti praedicatores"), as he calls them, who were apparently trying to relieve accusations against alleged witches based on their skeptical stance, is one important sign of the tense coexistence of different views concerning witch-beliefs among friars. ${ }^{19}$

Thus, the Franciscan preacher Roberto da Lecce tells, with a witty spirit, an anecdote describing how one of those vetulae even gets to the point of making fun of the belief in her own travelling at night and to gain something for herself out of such credulity:

In a certain town there was a dog-faced old woman, who used to go to the course [with the goddess Diana], and some women who had their husbands afar went to her, whose name was lady Simia, asking her one by one of their husbands. The old woman replied to them: "I will go to the course tonight, and I shall tell you tomorrow morning what I know, but bring to me a nice, fat Paduan crow", and that foolish woman brought that to her. The dog-faced old woman ate that all, and at times those women also brought her some good wine, so that, eating and drinking so well, she also slept well at night, waking up when the sun was already high. Thus, while the women were waiting to receive an answer, the depraved and malicious dog-faced woman, told them the first thing she had in mind, and sometimes she guessed it right, while other times she did not, in this way still eating the crow. ${ }^{20}$

17 El dimonio fa parere a quella mala femmina ch'ella diventi gatta e vada stregando, ma ella si sta nel letto suo. Lusioni di dimonio per ingannare altrui! See: (Bernardino da Siena 1934, p. 169).

18 (Roberto da Lecce 1517, fol. 18 ${ }^{\text {ra }}$ ). Cf.: (Augustine of Hippo 1955, pp. 47-48)

19 (Kramer 1496, pp. 285-86, fols Iii ${ }^{\mathrm{vb}}$-Iiii ${ }^{\mathrm{ra}}$ ). Cf: (Conti 2015, pp. 285-86).

20 Erat in quadam civitate una vetula rechagnata, que pergebat in cursu, et domine, que maritos procul habebant, ad eam proficiscebantur, vocabaturque domina Simia, ac ei dicebant, videlicet nunc una, modo altera velle scire quid viri sit. At illa: 'Me ac nocte in cursum oportet accedere, sciam in mane tibi dicere, sed feras mihi unam bonam gracillam magnam pinguem paduanam'. Illa pazarella eam ferebat. Vetulla [sic] vero rechagnata totam edebat, et aliquando ei optimum vinum ferebant, et ipsa, que bene ederat et biberat, etiam in nocte bene dormiebat, adeo quod, quando se excitabat, sol altus erat. Demum ille eam expectabant ut ab ea aliquod responsum haberent, sed rechagnata, viciosa, seu maliciosa eis responsum dabat secundum quod per prius cogitaverat, et aliquando verum divinabat et aliquando non, et hoc pacto gracillas edebat: (Roberto da Lecce 1983, p. 210). 
Simia, the "dog-faced" old woman, is thus said to go to the night train with Diana and certain women want to exploit her travels for the sake of knowing about their husbands who are far from home. In an exchange, the vetula asks for a fat, good jackdaw to eat. The women keeps providing Simia with food and wine so, full and happy after eating and drinking, the vetula sleeps during the night and wakes well into the day. In order to comply with her pact with the women, the old lady gives them different answers sometimes guessing right, and sometimes not. Roberto da Lecce treats this as a good and comical way to represent the nonsense of the belief in the witches' night train while at the same time showing his own attitude, not at all concerned about these beliefs, which he is working hard to delegitimize. We need to imagine the effect those short tales were intended to have on the audience during the preaching event, that of changing the beliefs and behaviors of the laity.

Through this, however, we are left to wonder: who could be considered a witch? This is a fundamental question for us as it was for the friars dealing with witch-beliefs within their communities. It was while the friars characterized the evil nature of the old woman or the vetula that they merged disparate traditions into the definition of such a character. For sure, there is not a simple and univocal path towards the characterization of the witch. These stereotypes and beliefs are interwoven much as the threads of a knitting. What we see is a process of amalgamation of different traditions, to which sometimes-diverging stances correspond.

The idea of evil, monstrous beings of female nature attempting at life, and especially at the life of babies, arrived to the study table of the fifteenth century friar from an old tradition rooted in Roman and Greek literature and mythology. ${ }^{21}$ As has been pointed out, the Roman literary tradition offers a varied characterization of what we would consider a witch, also pointing to her by different terminology, such as docta, divina, maga, saga, venefica, malefica, lamia, or by the simple periphrasis quaedam anus (some old woman), so close to the by then common quedam vetula, which we have already discussed. Central to the characterization of the witch is, however, the strix (pl. striges). ${ }^{22}$ The strix is a type of night bird, generally considered a screech owl, although this association only happened in modern times as Marina Montesano has pointed out. It was originally not considered an animal belonging to the natural world, but rather a monstrous creature of human (feminine)-bird appearance. The elegiac couplets of Ovid's Fasti give a popular description of these mysterious beings:

These are insatiable birds, not the harpies that deprived

Phineas of his feasts, although it is from them that they descend:

Their heads are large, their eyes unblinking, their beaks made for hunting;

Their wings are white, their talons hooked,

At night they fly and seek out children separated from their nurses

To snatch them from their cradles and rend their bodies;

They are said to tear out children's milky entrails with their beaks

And fill their gullets with the blood they have drunk.

There is a name for those birds-striges-so called

Because of their strident shrieking in the night.

Whether therefore they are born birds, or are made such by enchantment

And are nothing but women transformed into fowls by a Marsian spell. ${ }^{23}$

21 On this: (Montesano 2018, pp. 11-66).

22 (Paule 2018, pp. 8-9, 67-72).

23 Sunt avidae volucres, non quae Phineia mensis | guttura fraudabant, sed genus inde trahunt: | grande caput, stantes oculi, rostra apta rapinis; | canities pennis, unguibus hamus inest; | nocte volant puerosque petunt nutricis egentes, | et vitiant cunis corpora rapta suis; | carpere dicuntur lactentia viscera rostris, | et plenum poto sanguine guttur habent. | est illis strigibus nomen; sed nominis huius | causa quod horrenda stridere nocte solent. | Sive igitur nascuntur aves, seu carmine fiunt | 
"These are insatiable birds," Ovid says, and although not the same as the harpies that tormented the Thracian seer Phineus by stealing his food-as told in Apollonius' Argonautica (2, 178-499)—-they still descend in some ways from the harpies. The physical description of the striges does not bear a resemblance to the mythological appearance of the harpies, but reminds the reader of owls or birds of ill-omen mentioned by other Roman poets, with their large heads, unblinking eyes, beaks made for hunting, whitish wings, and hooked claws. Some other features of the striges will later become a constitutive part of witch-beliefs: they fly in the night, attack babies in their cradles, especially those lacking the care of a nurse (nutricis egentes), and their throats are full of the blood they have drunk. They are called striges, Ovid points out, because of the strident shrieks they emit in the night. ${ }^{24}$ The Roman poet does not provide indications on whether these creatures were old women changed into birds by Marsian spells or whether they were just born as birds. A possible answer to this issue, in the direction of asserting that these women were shapeshifters, can be found in Petronius' Satyricon, through the words of Trimalchio, when speaking of the striges (strigae in this text) he says that they are wise women and night-riders ("sunt mulieres plussciae, sunt Nocturnae"). ${ }^{25}$

Other popular figures of apparent witches in Latin literature, this time of human nature, and specifically "old women" (anus) such as Horace's Canidia and Lucan's Erichtho, share with the striges (and with the lamiae) most of their traits, especially their basic failure as mothers, the murdering and dismembering of children, magic rituals, and the association with the night. These characters also add elements or skills that will later join the other features in describing proper figures of witches. First are skills related to the ability of preparing potions and poisons, which will characterize such women as veneficae or poisoners. ${ }^{26}$ A figure of old woman that played a role in the subsequent medieval elaboration of the stereotype of the witch as a vetula is represented by Dipsas, both a bawd and a witch, of which Ovid gives an elaborate description in his Amores. Dipsas is never sober and has some supernatural and evil predispositions: she knows how to use herbs, she can make clouds gather in the sky or make the face of the Moon become blood-red, in the shadows of night she can presumably (suspicor, says Ovid) shapeshift with her old woman's body growing feathers, and she can summon ghosts as well as do harm by her tongue. These are all traits that for the most part become a steady presence in the characterization of the witches as vetulae. ${ }^{27}$

Trial records testify to the presence of the above mentioned elements well into the fifteenth century among the charges against women accused of being witches, such as the well-known case of Matteuccia of Todi, labeled a "woman of bad repute" and a witch, tried and condemned in $1428 .{ }^{28}$ The records attest to the alleged ability of Matteuccia to shapeshift into a cat (not an owl), which by then had already begun to represent the clear sign of the association of the woman with the devil. Above all, she was accused of entering houses under that guise and to attack children in their cradles by sucking their blood. The attacks against children offer some detail:

Furthermore, in that, around that, and above that, not satisfied with the aforementioned, in the month of May 1422 on a Thursday, she went to the village of Rotelle, in the district of Orvieto, for bewitching, and there she entered the house of a certain Mecarello, finding one of his daughters asleep in a cradle next to the bed of her father, and she beat and sucked [the blood of] that girl as she usually does. ${ }^{29}$

neniaque in volucres Marsa figurat anus: (Ovid 1989, pp. 131-42). English translations are available in (Paule 2018, p. 67; Montesano 2018, p. 55).

24 Cf. (Paule 2018, p. 67; Montesano 2018, pp. 55 ff). For an analysis of Ovid's text, see: (Littlewood 2006, pp. 45-47).

25 (Petronius 1925, pp. 9, 63). Cf.: (Montesano 2018, pp. 58-59).

26 (Montesano 1999, p. 104 ff.; Montesano 2018, p. 44 ff.; Paule 2018, pp. 74-79).

27 (Ovid 1914, 1.8.) Cf. (Cokayne 2003, p. 146; Cardini 1979, p. 37).

28 (Mammoli 1983, p. 14).

29 Item in eo, de eo et super eo, quod predictis non contenta, in $\mathrm{M}^{\circ} \operatorname{cccc}^{\circ}$ xxij ${ }^{\circ}$ de mense maij in die jouis, accessit stregatum | ad villam Rotelle, comitatus Urbeueteris et ibi ingressa fuit domum cuiusdam Mecharelli de dicto loco in qua in- $\mid$ uenit 
That phrase, "as she usually does" ("prout ipsa solita est facere"), carries its own significance outside of the contents of the present study and so will not be expanded upon. ${ }^{30}$ Matteuccia is also said to prepare potions and spells, as well as ointments with the fat of vultures and the blood of babies and owls in order to fly during the night. Her destination was named as the walnut tree of Benevento, where the witches were traditionally believed to congregate.

Similar accusations were leveled against other witches of the area of central Italy. Such was the other well-known case of Finicella, a woman convicted of being a witch who was burnt at the stake in Rome once Bernardino da Siena had preached in the urbs in 1426. Bernardino tells his audience about Finicella during one of the sermons he is delivering in Siena the following year: "Do you know what was done in Rome while I preached there? [ . . ] I want to tell you what was done in Rome." Thus, he explains how while he was preaching in Rome "About these enchantments and witches and spells, what I said seemed to them as if I was dreaming," but then the power of the words of the preacher spurs people to denounce, so that, Bernardino continues, "When I finished preaching, a multitude of witches (streghe) and enchanters were accused." Finicella appears, named, with the customary anti-witchcraft charge in the tale of the preacher while he says of the several witches who were arrested after his sermon: "One among the others [Finicella] said and confessed without any torture that she had killed thirty children by sucking their blood." 31 Finicella's being prone to infanticide by sucking the blood of children seems to connect well to centuries old stereotypes of which the Roman literary traits characterizing striges seem to be more than an echo.

Although recognizing the reality of the misdeeds of Finicella, as we saw, Bernardino expresses his skepticism about other elements of the rising witchcraft-mythology, such as, especially, shapeshifting. Interestingly, as I have shown, with the later fifteenth-century generation of the Observant Franciscan friars a clearer line of skepticism was elaborated directly targeting belief in witches that are called strege, this latter being a term that clearly recalls the figures of monsters of Roman literature with the charges traditionally associated with them. Thus, while writing of superstitious observances, Michele Carcano, a Milanese Observant Franciscan, points out that:

As to the observance of illusions, there is the observance of certain women who are misled and deceived and say that they go riding at night with Diana or Herodias, and that they transform themselves into other creatures that are popularly called strege. This is strongly opposed by the Council of Aquileia (through) 56, q. 5 of the canon Episcopi. ${ }^{32}$

The reality of the strege, which are the ancient striges, is questioned on the basis of the skeptical view expressed by the tenth century canon Episcopi. However, originally that text did not refer to these witches, but only to "certain women who are misled and deceived and say that they go riding at night with Diana or Herodias, and that they transform themselves into other creatures." 33 The recent witches, modelled on the ancient striges of the Roman tradition, enter the domain of the women travelling at night along with Diana, in turn, most probably referring to the bonae res or the fairies of medieval tradition. It was as if the negative stereotypes related to the diabolic power of certain women-the strege/striges - had been surviving across the ages and through the folklore as well as in literary and canonical texts, until they became part of a more recent blend of stereotypes that gave shape to what we can properly call witchcraft. In this way, some of the friars try to oppose the reality of some of these

quandam filiam dicti Mecharelli dormientem in quadam culla existente prope lectum dicti Mecharelli | et ipsam suam filiam percussit ac sucauit prout ipsa solita est facere: (Mammoli 1983, p. 34).

30 On bloodsucking, see: (Kieckhefer 1998, pp. 91-109).

31 (Bernardino da Siena 1989, vol. ii, pp. 1007-8). See (Ginzburg 1991, pp. 297-98; Mormando 1999, pp. 52-59).

32 De observatione illusionum qua observatione quedam mulieres decipiuntur et illuduntur que asserunt se cum Diana vel Herodiade nocturno tempore equitare, et se in alias creaturas transformare, que ideo vulgariter dicuntur strege. Nam huiusmodi valde detestantur per Concilium Aquilianum 56 q. 5 c. Episcopi: (Carcano 1492, Sermon 23, fol. 60 va). See: (Conti 2015, pp. 256-57).

33 (Kors and Peters 2001, p. 62). 
recent witch-beliefs by employing a text-the canon Episcopi-that had condemned belief in (or of) certain women about their night travels.

As the case of Finicella shows, the friars did not question the existence of evil women, or maleficae, willing to "cursing life" by killing children and willing to operate evil. ${ }^{34}$ What is questioned is the mythology centered on such a type of monster as the strega, which although rooted in the Classical tradition, enjoyed a connection with characterizing elements, such as night flight, shapeshifting, and participation in the Sabbaths. This eventually merged folkloric roots and Classical literary stereotypes, giving shape to something new.

Funding: This research received no external funding.

Conflicts of Interest: The author declares no conflict of interest.

\section{References}

Antonio da Vercelli. 1492. Sermones Quadragesimales de XII Mirabilibus Christiane Fidei Excellentiis. Venice: Giovanni e Gregorio de Gregori.

Augustine of Hippo. 1955. De Civitate Dei, 18, 16-18. Corpus Christianorum Series Latina; 2 vols. Edited by Bernhard Dombart and Alfons Kalb. Turnhout: Brepols.

Bailey, Michael. 2013. Fearful Spirits, Reasoned Follies: The Boundaries of Superstition in Late Medieval Europe. Ithaca: London: Cornell University Press.

Barry, Jonathan, and Owen Davies, eds. 2007. Witchcraft Historiography. Basingstoke: Palgrave Macmillan.

Bernardino da Siena. 1934. Le prediche volgari: Quaresimale fiorentino del 1424. 2 vols. Edited by Ciro Cannarozzi. Pistoia: Pacinotti, vol. 2.

Bernardino da Siena. 1989. Prediche volgari sul Campo di Siena 1427. 2 vols. Edited by Carlo Delcorno. Milan: Rusconi. Briggs, Robin. 1996. Many Reasons Why: Witchcraft and the Problem of Multiple Explanation. In Witchcraft in Early Modern Europe: Studies in Culture and Belief. Edited by Jonathan Barry, Marianne Hester and Gareth Roberts. Cambridge: Cambridge University Press, pp. 49-63.

Busti, Bernardino. 1498. Rosarium Sermonum. Venice: Giorgio Arrivabene.

Carcano, Michele. 1492. Sermones Quadragesimales de Decem Preceptis. Venice: Giovanni e Gregorio de Gregori.

Cardini, Franco. 1979. Magia, Stregoneria, Superstizioni Nell'Occidente Medievale. Florence: La Nuova Italia.

Chène, Catherine. 1999. 'Jean Nider, Formicarius' [II.4]. In L'imaginaire du sabbat: Edition critique des textes les plus anciens (1430 c. -1440 c.). Edited by Martine Ostorero, Agostino Paravicini Bagliani and Kathrin Utz Tremp. Lausanne: Cahiers Lausannois d'Histoire Médiévale.

Cokayne, Karen. 2003. Experiencing Old Age in Ancient Rome. London: Routledge.

Conti, Fabrizio. 2011. Preachers and Confessors against 'Superstitions'. Bernardino Busti and Sermon 16 of his Rosarium Sermonum. Magic, Ritual, and Witchcraft 6: 62-91. [CrossRef]

Conti, Fabrizio. 2015. Witchcraft, Superstition, and Observant Franciscan Preachers: Pastoral Approach and Intellectual Debate in Renaissance Milan. Turnhout: Brepols.

Conti, Fabrizio. 2016. Grids for Confessing Sins. Notes on Instruments for Pastoral Care in Late Medieval Milan. In Religious Orders and Religion Identity Formation, ca. 1420-1620: Discourses and Strategies of Observance and Pastoral Engagement. Edited by Bert Roest and Johanneke Uphoff. Leiden: Brill.

Diodorus, Siculus. 2000. The Library of History II. Reprint. Translated by Charles Henry Oldfather. Book 3, $49-61$. Cambridge: Harvard University Press.

Diodorus, Siculus. 2002. The Library of History X. Reprint. Translated by Russel M. Geer. Book 20, 41. Cambridge: Harvard University Press.

Ginzburg, Carlo. 1991. Ecstasies: Deciphering the Witches' Sabbath. Translated by Raymond Rosenthal. Chicago: University of Chicago Press.

Ginzburg, Carlo. 1992. The Night Battles: Witchcraft and Agrarian Cults in the Sixteenth and Seventeenth Centuries. Translated by John Tedeschi, and Anne Tedeschi. Baltimore: The Johns Hopkins University Press.

34 (Conti 2015, pp. 221-46). 
Henningsen, Gustav. 2001. The Ladies from Outside: An Archaic Pattern of the Witches Sabbath. In Early Modern European Witchcraft: Centres and Peripheries. Reprint. Edited by Bengt Ankarloo and Gustav Henningsen. Oxford: Clarendon Press.

Herolt, Johannes. 1497. Sermones Discipuli de Tempore et de Sanctis. Lyon: Jean de Vingle, Sermon 41.

Isolani, Isidoro. 1506. Libellus Aduersus Magos, Diuinatores, Maleficos. Milan: Giovanni Angelo Scinzenzeler.

Kieckhefer, Richard. 1998. Venging the Blood of Children: Anxiety over Child Victims and the Origins of the European Witch Trials. In The Devil, Heresy, and Witchcraft in the Middle Ages: Essays in Honor of Jeffrey B. Russell. Edited by Alberto Ferreiro. Leiden: Brill, pp. 91-109.

Kieckhefer, Richard. 2006. Mythologies of Witchcraft in the Fifteenth Century. Magic, Ritual, and Witchraft 1: 79-108. [CrossRef]

Kieckhefer, Richard. 2013. The First Wave of Trials for Diabolical Witchcraft. In The Oxford Handbook of Witchcraft in Early Modern Europe and Colonial America. Edited by Brian P. Levack. Oxford: Oxford University Press, pp. 159-78.

Klaniczay, Gábor. 2008. Learned Systems and Popular Narratives of Vision and Bewitchment. In Demons, Spirits, Witches, 3: Witchcraft Mythologies and Persecutions. Edited by Gábor Klaniczay and Éva Pócs. Budapest: CEU Press, pp. 50-82.

Kors, Alan Charles, and Edward Peters, eds. 2001. Witchcraft in Europe, 400-1700: A Documentary History, 2nd ed. Philadelphia: University of Pennsylvania Press.

Kramer, Heinrich. 1496. Tractatus Varii Cum Sermonibus Plurimis. Secunda Pars. Nürnberg: Anton Koberger.

Littlewood, R. Joy. 2006. A Commentary on Ovid: Fasti Book 6. Oxford: Oxford University Press.

Mammoli, Domenico, ed. 1983. Processo alla strega Matteuccia di Francesco 20 Marzo 1428. Todi: Res Tudertinae.

Montesano, Marina. 1999. "Supra Acqua et Supra ad Vento". "Superstizioni, maleficia e incantamenta nei predicatori Francescani Osservanti (Italia, sec. XV). Rome: Istituto Storico Italiano per il Medioevo.

Montesano, Marina. 2018. Classical Culture and Witchcraft in Medieval and Renaissance Italy. Cham: Palgrave Macmillan.

Mormando, Franco. 1999. The Preacher's Demons: Bernardino of Siena and the Social Underworld of Early Renaissance Italy. Chicago: The University of Chicago Press.

Ovid. 1914. Amores. In Heroides. Amores. Translated by Grant Showerman. Revised by George Patrick Goold. Loeb Classical Library 41. Cambridge: Harvard University Press.

Ovid. 1989. Fasti. Reprint. Translated by James Jeorge Frazer. Cambridge: London: Harvard University Press.

Paule, Maxwell Teitel. 2018. Canidia, Rome's First Witch. London: Bloomsbury.

Petronius, Seneca. 1925. Satyricon, Apolocyntosis. Translated by William Henry Denham Rouse, and M. A. Litt. Cambridge: London: Harvard University Press.

Regino of Prüm. 1880. De Ecclesiasticis Disciplinis et Religione Christiana Libri Duo, II. PL 132. Edited by J. P. Migne. Paris: Garnier Fratres.

Roberto da Lecce. 1517. Spechio de la Fede Vulgare. Venice: Piero de Quarengis Bergomascho.

Roberto da Lecce. 1983. Quaresimale Padovano 1455. Edited by Oriana Visani. Padova: Messaggero.

Savonarola, Girolamo. 1510. Eruditorium Confessorum. Paris: Parvus.

(C) 2019 by the author. Licensee MDPI, Basel, Switzerland. This article is an open access article distributed under the terms and conditions of the Creative Commons Attribution (CC BY) license (http://creativecommons.org/licenses/by/4.0/). 


\title{
Article \\ "Such Fictitious Evil Spirits": Adriaan Koerbagh"s Rejection of Biblical Demons and Demonic Possession in A Light Shining in Dark Places (1668)
}

\author{
Ismael del Olmo \\ History Department, Faculty of Philosophy and Letters, University of Buenos Aires, Buenos Aires C1406CQJ, \\ Argentina; delolmoismael@hotmail.com
}

Received: 13 March 2019; Accepted: 15 April 2019; Published: 19 April 2019

\begin{abstract}
This paper traces Adriaan Koerbagh's interpretation of biblical devils and scriptural instances of demonic possession in his 1668 Een Ligt Schijnende in Duystere Plaatsen (A light shining in dark places). Koerbagh's book is a radical exponent of the early Dutch Enlightenment, and its views on demonology are of importance if we want to assess the extent to which traditional scholastic pneumatology was challenged in the second half of the XVIIth century. This paper will also address Thomas Hobbes' positions regarding demons and demonic possession in Leviathan (1651), given that Hobbes' interpretations were fundamental to Koerbagh's own positions. We will focus on the Hobbesian exegetical strategies of etymology, naturalization, and metaphorization, which helped Koerbagh to point at diseases, evil thoughts, figures of speech, or human enemies as plausible explanations for scriptural passages concerning devils and possession. But we will also see that Koerbagh's Cartesian definition of spirits led him to a more radical stance than that of Hobbes: demons do not exist at all. This paper will end by claiming that Koerbagh's interpretation of Christian demonology both as a remnant of Pagan and Jewish superstitions, and a knowledge indifferent to salvation-themselves Hobbesian principles - went hand in hand with his attempt to secularize the biblical text. Thus, the devil, once a part of the sacred truth, could now be seen as a fragment of a human cultural heritage.
\end{abstract}

Keywords: Adriaan Koerbagh; demonology; demonic possession; biblical exegesis; Thomas Hobbes

\section{The Late XVIIth-Century Attack on Demonology}

It is a well-known fact that the Reformed minister Balthasar Bekker (1634-1698) committed an intellectual arson with his De Betoverde Weereld (The World Bewitched), published in four volumes between 1691 and 1693, and soon translated into French, English, and German. A controversial tour de force around the subject of demonology, the book may well be the most comprehensive critique of the idea of the devil ever written. Arguing from a hyper-providentialist stance-belief in God's absolute power was threatened by the supposed power of the devil, and even by angelic mediators-the book includes attacks on demonic possession, sorcery, witchcraft, counter-magic, and traditional beliefs about spirits; it also offers a comparative approach towards world demonologies. In order to deactivate the power of the devil in the material realm, De Betoverde Weereld accepts the Cartesian separation of mind and body and the concomitant principle of the impossibility of the interaction between thought and extension (pineal glanded humans excepted). Bekker supported his claims through Revelation. The Scripture is adamant in its claim that Satan was defeated and chained in Hell, and has no power over worldly events. Bekker's book thus re-interpreted the key biblical passages involving demons and their operations under a dissident exegetical light, suggesting metaphors, figures of speech, Hebrew and Greek etymologies, and natural explanations to account for purported demonic entities and activities (Vermeir 2013; Van Bunge 2000; Van Ruler 2000; Fix 1999; Israel 1996; Fix 1989; 
Attfield 1985). Undoubtedly, Bekker helped to accelerate a trend already present in early modern intellectual circles: the degradation of scholastic demonology as sheer superstition (Cameron 2010, pp. 264-69). His ideas were discussed in contemporary circles in a full-scale debate, and rejected by religious institutions-Bekker, accused of scandal and heresy, was denied communion and suspended from his ministry. It has been said that his views on the demonic even had an impact on popular culture; hence, Bekker could be credited for extending his proto-Enlightenment teachings outside the scholarly world (Wielema 2004, pp. 53-78).

One of the many contributions to the debate around Bekker's book was a 1691 anonymous Dutch poem, which refers to Bekker as one "whose intellect challenges the power of the devil" (wiens brein des Duyvels macht betwist). The author proposed an ironic "justification" (onschuldiging), stating that "you cannot blame this teacher for the texts he has written" (Geen schult kan men dees Leeraar geven/Van't geen dat hy heeft uytgeschreven), "because he cannot even speak for himself" (Door dien hy selfs niet spreken kan). It is clear who was at fault here: the "company of cunning heretics" (Een party ketters vol van list) whose works Bekker had read. Who were they? Among other names, the author lists "Hobbes" and "Spinosa" (Anonymous 1691, p. 7). ${ }^{1}$

Most likely, the poet is thinking about Leviathan (1651), Thomas Hobbes' (1588-1679) masterpiece. Although Elements of Law (1640) already offers a discussion about "angels good and evil", Hobbes devotes this brief account mainly to his rejection of the scholastic notion of incorporeal substances (Hobbes 1928, pp. 42-43). It is only in his influential Leviathan that Hobbes writes several chapters arguing at length against the early modern biblical and philosophical interpretation of the devil-we will develop these points later in the article. ${ }^{2}$ With regards to Baruch Spinoza (1632-1677), the reference is unclear: we are certain that the poet was not aware of the 1661 Short Treatise, an unpublished manuscript in which an entire chapter questions the existence of the devil (Spinoza 2002, pp. 98-99). Was the poem referring, then, to Spinoza's Theological-Political Treatise (1670), in which the biblical "evil spirit" is taken as the human passion of hatred and melancholy? (Spinoza 2007, p. 22). Was the poet thinking about Spinoza's famous letters to Hugo Boxel in the last months of 1674, where the philosopher attacked the belief in ghosts, apparitions, and incorporeal spirits? (Spinoza 1995, pp. 261-79). Or is the poem addressing Spinoza's reply to Albert Burgh in 1675, in which the excommunicated Jew

1 "Geen schult kan men dees Leeraar geven

Van't geen dat hy heeft uytgeschreven

Wel is't Heer Beckers Boek dan niet

Dat een Betooverd' Wereld hiet?

Wel neen, de man die heeft gesproken

Met Schot, met Paling, van het spoken

Met Carolyn, met Dellion

Montanus, Dapper, die hy kon

Spinosa, Hobbes, al haar geest

Vind g'in sijn boek, als gy't doorleest

De Alcoran en Talmuts zeden

Gebruykt hy, voor sijne eygen reden

En Koerbach moest ik niet vergeten

En and're op dien stoel geseten

Een party ketters vol van list

Die maken niet als haat, en twist

Meer and're geesten, als Van Dalen

Die'k alle nu niet op wil halen

Men doet dan ongelijk de man

Door dien hy selfs niet spreken kan".

I would like to express my deep gratitude to Wendy Wauters (Katholieke Universiteit Leuven) for translating this passage. The anonymous reviewer of the article has also given valuable insight on the meaning of the poem. On another note, the anti-demonological influence of many of the authors considered in this poem, such as Abraham Palingh and Antonius Van Dale, is analyzed in. (Waite 2018)

2 For Hobbes' understanding of demons and its impact, see, among others, (Del Olmo 2018; MacMillan 2014; Bath and Newton 2006; Schaffer 1985; Jobe 1981). 
accuses Burgh of fearing the Prince of Darkness, and thus, to have fallen in the hands of superstition? (Spinoza 1995, pp. 340-44). Be it as it may, it is clear that Hobbes and Spinoza were perceived as declared enemies of Christian demonology and thus as legitimate forerunners of Balthasar Bekker.

The Dutch poet also adds this brief note to the list of Bekkerian influences: "I must not forget Koerbach" (En Koerbach moest ik niet vergeten) (Anonymous 1691, p. 7). This is Adriaan Koerbagh (1632-1669), one of the most intriguing figures of the early Dutch Enlightenment (Salatowsky 2017; Israel 2001, pp. 185-96; Wielema 2003a, pp. 571-74; 2003b, 2001). The poem could be alluding to Een Blomhof van allerley lieflijkheyd (A flower garden of all sorts of loveliness), published in February 1668. Organized as a dictionary, the book translates and analyses what Koerbagh calls "bastard words" in Hebrew, Greek, Latin and French, which were used daily in the practice of Law, theology, and medicine. Koerbagh portrays the book as an attack on what he perceived as the language of the elite, designed to deceive ordinary people. Here, he rejected the early modern idea of the devil in one short entry, "Duyvel" (Koerbagh 1668, pp. 258-59). But Adriaan's most important contribution to the intellectual history of demonology, and the one we will study in this paper, is Een Ligt Schijnende in Duystere Plaatsen (A light shining in dark places), finished also in 1668 (Koerbagh 2011; Van Bunge 2011, pp. 1-38). ${ }^{3}$ Arguably one of the most radical texts of the early modern period, it contained among other dissident ideas an elaborated diatribe against the devil and demonology.

Koerbagh, a doctor of medicine and law, entered Spinoza's inner circle at the beginning of the 1660 's, sharing with its members the critique towards the scriptural and political foundations of revealed religions and Christian confessions. A light shining in dark places, an outspoken radical work, poured scorn on the irrationality of organized religious beliefs, labeling them as sheer superstitions. As with his A flower garden, the book was devised as a tool for the philosophical enlightenment of the people and to this end, it was written in Dutch and in a straightforward style-fatal mistakes that Spinoza would never make ("caute"). ${ }^{4}$ Due to the scandal that arose with $A$ flower garden, the book, labeled as "atheisticum" in Reformed circles, was suppressed in Amsterdam and confiscated in Utrecht (Israel 2001, p. 190)—Koerbagh fled to the autonomous county of Culemborg. He carried with him the manuscript of his new oeuvre. After working through almost 180 pages of $A$ light shining in dark places, an increasingly horrified printer at Utrecht alerted the local officials about Koerbagh's manuscript. Word soon reached Amsterdam, and its authorities issued a warrant, seized the runaway Adriaan in Leiden, brought him back to Amsterdam, interrogated him, and condemned him in July 1668 to ten years in prison under the charge of blasphemy. He lasted a little more than one year, dying in October 1669. Censorship was brutal: only two copies of A light shining in dark places survive today, presumably those the authorities used to build up the case (Nadler 2011, pp. 38-51).

It seems clear that, in his search for Bekker's influences, the anonymous Dutch poet was trying to identify the main suspects involved in what Jonathan Israel has called "the death of the devil" (Israel 2001, p. 375). It is hard to know whether such demonicide was ever perpetrated, as belief in devils and demonology continued in the late modern period and beyond (Gijswijt-Hofstra et al. 1999). But there is no doubt that during the second half of the XVIIth century, reaching a peak with Bekker's contribution, the medieval and early modern idea of the Enemy was under heavy fire. Given that the science of devils was deeply entwined with exegetical tradition, scholastic physics and metaphysics, and crystalized assumptions about the power of the Christian churches and its heralds, anti-demonic

3 There is doubt about the involvement of Adriaan's brother, Johannes Koerbagh (1634-1672), a theologian, in the writing of the book (Wielema 2004, p. 85; Israel 2001, p. 195).

4 Indeed, Wielema claims that Koerbagh's works "are certainly far more outspokenly anti-Christian than anything Spinoza ever dared to write. In addition, Koerbagh wrote purposely in Dutch in order to enlighten not just the academic elite but, more importantly, the common people as well" (Wielema 2004, p. 85). Let us remember that Spinoza published his Theological-Political Treatise anonymously and in Latin, and the place of publication and the name of the printer were false ("Hamburgi, apud Henricum Künraht"). Furthermore, after the scandal brought by the book, he did not publish anything else. This is one of the main reasons why Antoine Lilti has challenged Israel's view of Spinoza as the origin of the "radical" Enlightenment (Lilti 2009; Israel 2001). 
attacks had obvious implications at the level of Biblical exegesis, natural philosophy, theology, and politics—or, following Spinoza's perceptive terminology, at the theologico-political level. In this paper, I aim to trace these implications by focusing on one particular vignette of the crusade against the early modern devil: the views on evil spirits and demonic possession found in Koerbagh's A light shining in dark places. To my knowledge, there is no detailed study on this subject. A thorough consideration of Koerbagh's anti-demonological positions will be useful to assess the extent to which traditional early modern pneumatology - that is, the scholarly notions on spirits, their ontology, their powers over causality, and the ways they interacted with bodies-was rejected in the early Enlightenment.

In searching for Koerbagh's views on the devil and demonic possession, we will have the opportunity to assess the influence of Thomas Hobbes, one of the main figures among those anti-demonological "cunning heretics" mentioned by the Dutch poet. Koerbagh knew Leviathan well, as Gerrit Jongeneleen has made clear in his systematic research on Hobbes' impact on Adriaan's thought (Jongeneelen 1991). In fact, Leviathan is the only contemporary book from which Koerbagh openly quotes; furthermore, he had a close friendship with its translator into Dutch, Abraham van Berkel, also a member of Spinoza's clique (Wielema 2017). ${ }^{5}$ It is known that, England excepted, the Dutch Republic was the territory in which Hobbes' works exerted their greatest influence (Malcolm 2002, pp. 27-52). And this influence seems crucial to the radicalism of the Dutch Enlightenment: as an author has put it, Hobbes was "the fountainhead of intellectual contamination and religious heterodoxy in the second half of the seventeenth century" (Champion 2012, p. 95). Highlighting Hobbes' presence in Koerbagh's demonology would be in line with Noel Malcolm's critique of Israel's concept of "radical Enlightenment" essentially as a Spinozist and underground phenomenon. As Malcolm suggests, one should not despise changes within mainstream theology, mainstream metaphysics, and mainstream psychological and moral theory, changes that could lead to radical reactions; in this sense, between Spinoza and Hobbes, the latter was the most influential of the two in the European intellectual landscape (Malcolm 2002, pp. 535-37). ${ }^{6}$

Did Hobbes influence Koerbagh's anti-demonological arguments? And if he did, to what extent? On the one hand, we shall see that Hobbes seems to have had an important impact on Koerbagh's anti-demonological exegesis, which includes a radical etymological interpretation of the names and words traditionally attached to the Christian evil spirit ("Satan", "Abaddon", "devil", "angel"), and the naturalization and metaphorization of biblical devils and instances of demonic possession. We will encounter this Hobbesian imprint again in our conclusion, when evaluating Koerbagh's claim regarding the Pagan origins of demonology, and his rejection of devils as utterly irrelevant in matters concerning salvation.

Nevertheless, on the other hand, it seems clear that Koerbagh surpassed Hobbes in his radicalism. Concerning anti-demonological arguments, Jonathan Israel does indeed mention Hobbes as a main influence on the XVIIth-century's skepticism towards devils. But he adds that "proceeding several steps further, from the 1660s, the founding fathers of philosophical radicalism initiated their campaign, negating Satan, spirits, and supernatural forces altogether in complete defiance of received ideas" (Israel 2001, p. 375). We may place Koerbagh among those whom proceeded "several steps further". This is a direct consequence of different metaphysical frames. Hobbes' critique of evil spirits is part of his attack on the notion of "incorporeal substances", an essential element of scholastic pneumatology. Hobbes argues that, together, these terms imply an outright contradiction: substances, as part of the res of the universe, occupy space. Spirits exist, but they are subtle and invisible bodies, like the air and the

5 In order to escape trial after the scandal caused by A flower, Koerbagh fled to Culemborg, where he joined Van Berkel, already in hiding after his controversial Dutch edition of Leviathan in 1667. Furthermore, Van Berkel assisted Koerbagh in reading proofs for A light shining in dark places, and tried to convince the printer in Utrecht-who would eventually alert the authorities about the book—to finish the job (Israel 2001, p. 190; Van Bunge 2001, p. 101).

6 For Malcolm's debate with Israel, see (Springborg 2004). 
vital spirits. Furthermore, Hobbes had to admit that Scripture forces us to acknowledge not only that spirits exist, but that there are such things as evil spirits (Hobbes 2012, pp. 7, 207, 210-11, 214, 371-73).

I consider, then, that Jongeleen misses the point when, searching for Hobbes' influence on Adriaan, he affirms: “Comme Hobbes, Koerbagh nie l'existence d'esprits spirituels: ce qu'on appelle un mauvais esprit n'est rien d'autre que le Vice qui empêche le soutien divin de s'effectuer" (Jongeneelen 1991, p. 257). The first part of the sentence is correct: Hobbes denies that there are "spiritual spirits"; but he does not reduce the "mauvais esprit" to vice: they could also be substances. On the contrary, as we shall see below with more detail, Koerbagh took a more radical stance. He made use of a Cartesian definition of spirit: "a spirit consists in thought", or, alternatively, "a spirit is a thinking thing". Being pure thought, disembodied spirits could never act on matter (Koerbagh 2011, pp. 59, 61; Wielema 2003b, p. 73). Thus, Koerbagh's metaphysics shows that the Christian devil, a substantial entity with will and capacity to intervene in the material world, is an error. This is a depart from Hobbes' anti-demonology, a depart connected with Koerbagh's Cartesian philosophy, but also with his views on Revelation: whereas Leviathan affirms that Scripture forces us to acknowledge demons as substantial beings, A light shining in dark places went on to deny that demons were part of Revelation. It remains true that, in order to support these claims when discussing demons in the Scripture, Koerbagh deployed the exegetical weapons of etymology, and the naturalization and metaphorization of devils and their activities, strategies which Leviathan had systematized more than a decade earlier. But these were now pointing in a more radical direction than Hobbes imagined (or dared to affirm): denying the very existence of evil spirits.

The conclusion will underline Koerbagh's emphasis on the rejection of demonology as a pernicious Pagan doctrine, alien to Christianity's true message. This went hand in hand with what, for lack of a better term, we may refer to as a strong secularizing effort on Koerbagh's part: he insists that several biblical passages are better understood in light of natural reason and natural causality, debunking previous claims to supernatural or demonic causalities. As stated above (and as we will argue below), Hobbes may have inspired Koerbagh's view, according to which these passages hold no importance whatsoever to men's salvation. In this line, I will conclude this text mentioning what it seems to me to be the driving force behind Koerbagh's views on devils and demoniacs: the understanding of (part of) the Scripture not as sacred truth but as cultural heritage.

\section{2. "We Rightly Reject the Fabricated Evil Spirits": Explaining Away Spirits and Demons}

Adriaan Koerbagh frames his arguments against demonology as an attack on the affinities between organized Christianity and superstition. This diatribe stems from A light shining in dark places's approach towards "rational religion". Abandoning the true knowledge of God, theologians and their flocks "have fallen from a rational religion to a religion full of superstitions, fictions and fabrications". This is often due to the difficulty of Scripture itself, worsened by the ignorance of those in charge of understanding and explaining it. Indeed, "the errors and fallacies of the divines in theology and religion" are due to "the obscurity and confusion of Scripture, further increased by false interpretation" (Koerbagh 2011, pp. 47,219$)$. In this section, we shall analyze one crucial element of this blend of irrational religion, false exegesis, and theological ignorance: the devil.

It has been noticed that Koerbagh thought that an important metaphysical fiction pervading religions was the belief in the existence of incorporeal and spiritual entities capable of operating in the material world (Wielema 2003b, p. 72). Hence, our discussion on Koerbagh's devils must tackle his views on pneumatology. In this line, it is striking to learn that Koerbagh published a Spinozist book before Baruch Spinoza had the chance to deliver his philosophy to the printing press-in fact, during his trial, Koerbagh was asked if his metaphysical ideas derived from Spinoza's "pantheism", and if he 
shared his interpretation of the Bible with the excommunicated Jew (Van Bunge 2011, pp. 28, 32). ${ }^{7}$ A light shining in dark places affirms that God is a simple, unique, eternal, infinite Being with two known attributes, thought and extension. This Being, the only substance, is all in all, "so all that one sees, hears and feels is nothing but a mode of being dependent on this Being". Now, this Being has often been misunderstood, even by the authors of Scripture. John 4: 24, for example, states that "God is spirit". But the Apostle "does not say or explain what a spirit is or what is the nature of a spirit". On a footnote, Koerbagh gives the Greek etymology for the word "spirit" (pneuma) as "breathing, blowing, emitting wind, giving off smell". It is clear, then, that if the Greeks portray God as a spirit, they "never knew what a spirit is". And what is it? As we have seen above, Koerbagh defines it in a Cartesian way: "a spirit consists in thought", "a spirit is a thinking thing" (Koerbagh 2011, pp. 59, 61).

This critique of the traditional notion of "spirit" is of obvious importance for the book's understanding of devils. Koerbagh highlights that the Christian Church is very interested in the subject of demonology, and "the theologians insist that we believe in evil spirits". He refuses to comply: "I deny that there are such fictitious evil spirits as the clergy say there are" (Koerbagh 2011, pp. 235, 425). As we saw in the introductory section, his opposition is philosophical, given that Cartesianism indicates that a disembodied spirit cannot act on matter. In this line, Koerbagh states, for example, that "it is said of the invented evil spirits" that they seduce people, or even kill them, actions that "do not belong to a spirit". But they do take place amidst human beings, who are spirit and body. Thus, "evil spirits" should not be considered as "independently existing spirits" or entities "outside the human domain"; often, it is "a human being who is someone else's evil spirit". Alternatively, if not human enemies, these "evil spirits" could be understood as "evil thoughts" and inner dispositions: we can be seduced to all kinds of evil and be led to "a disquiet and unhappy state" by ignorance, desire for money, yearning for status, and immoderation. Given that these things "exist in our souls, which are spirits ( ... ), one may call them, although not quite accurately, spirits". In conclusion, for Koerbagh the "evil spirits" must be seen as "twofold, physical and spiritual": one's own thoughts and dispositions, and one's own human enemies (Koerbagh 2011, pp. 429, 451,453). As we will see, this definition opens the door to the naturalization and metaphorization of evil spirits and spiritual distress.

But if this is so, what are we to do with biblical evil spirits? Here, A light shining in dark places is in tune with Thomas Hobbes' etymological analyses of the scriptural terms that were applied to the Enemy for centuries, as well as with Leviathan's exegetical strategies of naturalization and metaphorization of biblical passages concerning demons. Hobbes affirms that in the Bible, "spirits" may refer to (a) substances; (b) metaphors; (c) "an office, or quality"; (d) diseases; or (e) mental images. First, as we saw, Hobbes believed that the Scripture forces us to acknowledge the existence of evil spirits; but nothing forbids us to affirm that these are corporeal substances. Second, an evil spirit may stand, in a metaphorical sense, for a disposition or inclination: an "unclean spirit" refers to an evil disposition (Hobbes 2012, p. 208). Third, etymology shows us that "Satan", "Devil", "Abaddon", and "angel" are offices and qualities (respectively, "enemy", "accuser", "destroyer", "messenger"); these biblical terms, which should have never been left untranslated by the theologians, address not substantial spirits, but earthly human enemies of the Kingdom of God, or God's messengers (Hobbes 2012, pp. 213, 244). Fourth, several instances in which the Bible uses the word "spirit" could be interpreted simply as the way in which Pagans, Jews, and early Christians, ignorant of natural causes, understood mental diseases (Hobbes 2012, p. 208). Finally, we may think of "spirits" as mental images; that is, the product of a deceptive sense perception, dreams, and visions (Hobbes 2012, p. 210).

Koerbagh favors Hobbes' interpretation of biblical spirits as metaphors, natural diseases, earthly enemies, and messengers. This is evident in his etymological critique. For him, as for the English thinker, the clergy is at fault in not translating Satan, devil, or Abaddon, words that mistakenly imply

7 The interrogators asked Koerbagh about his relationship with Spinoza: "He admitted to having spent some time with Spinoza, to having gone to his home on different occasions, but he had never spoken of this affair with him ( ... ). [He] affirms that he never spoke of this doctrine [Biblical exegesis] with Spinoza" (quoted in (Nadler 2011, p. 44)). 
that the Scripture is speaking of proper names, or, as Koerbagh puts it, of "spirits in particular". As Leviathan contends, these terms refer to actions or dispositions. Note that Koerbagh—as he had already done in his 1668 dictionary, A flower garden - proposes accurate translation as a way to enlighten the general public: if theologians do not wish to give the proper meaning of the biblical text, Koerbagh will, "so that the common people may arrive at an understanding of such matters" - and once this is achieved, that they may reject Christian demonology altogether (Koerbagh 2011, pp. 422, 453).

Diaboloi, for example, is Greek for "slanderers", "accusers", "deceivers". Satan is Hebrew for "adversary or opponent", and "resister". In addition, while the theologians repeat that Satan or diaboloi "can only be said of evil spirits", the Scriptures also uses them to refer to "good spirits" and "people". In the same line, the term Abaddon means "destroyer, disrupter", and it is said, says Koerbagh, not of "fabricated evil spirits", but of "evil people ( ... ) destroying and disrupting [the] peace". The same holds true for "angels" (aggelos), which means "messengers", and that we should apply to "human messengers". Koerbagh also points out that, in the Bible, the devils "carry the name of several evil actions they perform". The Greek word diaballein, for example, means "speaking evil, blaming, accusing, informing, gossiping, and deceiving" (Koerbagh 2011, pp. 422, 425, 429).

He also analyzes the Greek word daimon. An ambiguous term to say the least, it can mean "God", "wise", "a hero or famous person", and a "hellish" or a "heavenly" god. The Greeks, "full of superstition", said that these daimones could also be spirits "good or evil". It is on these "fictions and nonsense" that Christian theologians rely-although, here, the clergy adds something of their own: that demons are "disembodied spirits ( ... ) evicted from heaven", a notion alien to the Pagans. Be it as it may, since the Greeks "never provided any clear proof" of the existence of these spirits, Koerbagh favors an alternative meaning for daimon: "the inborn nature of man". Thus, "someone with a good nature also has a good soul or spirit, and ( ... ) one with a bad nature also has a bad soul or spirit". From this word one can also derive daimonân, which stands for being "senseless, insane, or mad and raving" (Koerbagh 2011, pp. 433, 435). As we may see, etymology reinforces Koerbagh's strategy of naturalization and metaphorization of Biblical passages concerning devils: they are evil humans, evil dispositions, or mental disorders.

Let us now turn to Koerbagh's interplay between etymology, exegetical strategy, and Cartesian metaphysics. Matthew 4:1-11 records that "the devil", "Satan", appeared to Jesus in the wilderness, and took him to a high mountain in order to tempt him. It is worth noting that Hobbes analyzes the same story (adding Luke's version, 4:1-13), claiming that demonic temptation happened in Jesus' spirit, as a vision (Hobbes 2012, p. 354). Koerbagh agrees, at least in part: the demonic temptation comes not from without, it happens not outside Jesus' mind, but inside of him. This follows from his Cartesianism: being thought, "a spirit cannot lead someone away or take him somewhere and lead him to a high mountain". Clearly, theologians cannot use this passage as proof of the existence of a devil named Satan. What is Matthew saying, then?

It is true that I deny that there are such evil spirits as the clergy say there are, but I have not denied that there can be evil thoughts by which someone can be assailed as if by evil spirits, because thoughts spring from the mind. (Koerbagh 2011, pp. 235-37)

This implies a radical turn regarding Hobbes' interpretation: since metaphysics indicates that "evil spirits" may simply mean "evil thoughts", the passage does not evoke Jesus' vision, but a metaphor, a representation of his inner battle. "There was a mental struggle in his mind", between preaching the truth with no regard for his own safety, and a "strong desire for vain worldly status, or money" (Koerbagh 2011, p. 237). ${ }^{8}$ But what about Satan? Koerbagh's reading is again far more radical than Hobbes', and resulting in a highly heterodox version of Christ's demonic temptation: since "Satan", as we saw, can be translated as "adversary" or "tempter", this term may allude "to one of the closest

8 Koerbagh insists on this idea later on: if the word diaboloi means "accusers", who is the most powerful accuser at God's disposal? Not "any fabricated evil spirits", certainly, but "someone's own conscience" (Koerbagh 2011, p. 422). 
friends of the Saviour", an Apostle. Before Jesus went to the desert, one of his followers could have tried to convince him of giving up his dangerous mission. This may have given Jesus doubts: "there arose in his mind, asked when he was alone, such a struggle as we have described" (Koerbagh 2011, pp. 237,239$).{ }^{9}$

Let us see another example, the meaning of evil "angel". Koerbagh takes two passages, 2 Peter 2:4 and Jude 6, concerning angels who have erred and are punished by God. Hobbes quotes these verses in order to support his theory of angelic materiality against the scholastic notion of angels as "incorporeal substances": the passages, speaking about evil spirits being tormented or chained, show that "Angels (... ) are not thence proved to be Incorporeal"; they "prove the Permanence of Angelical nature", and "confirmeth also their Materiality" (Hobbes 2012, p. 213). However, we should note that a couple of lines above, quoting Matthew 25:41, Hobbes does suggest that these evil spirits could be, in fact, evil humans: "The name of Devil and his Angels may be understood of the Churches Adversaries and their Ministers" (Hobbes 2012, p. 213). Koerbagh is here, once again, more radical than Hobbes. Since his metaphysics forbids the existence of evil spirits as substances, he is not interested in debating the materiality or immateriality of "angels"; these passages clearly allude to human beings, and only to them. For example, 2 Peter 2:4: "God did not spare the angels when they sinned, but cast them into hell, and committed them to pits of nether gloom to be kept until the judgment". This passage is often incorrectly signaled as proof of "the fall of the spirits", an unwarranted assumption since nothing is said about evil spirits. The key word here is "angel": as we saw earlier, this means "messenger", and it refers, not to spirits, but to "human messengers" (Koerbagh 2011, p. 427). Peter wrote about angels who erred, which can be interpreted as "prophets or teachers who go astray". The passage, thus, speaks of

angels who said that they came on the orders of God to the people to proclaim their message, but who erred, that is, lied, which is not from God, and that God did not spare them but threw them into hell or down below, that is, cast them out or rejected them and delivered them to the chains of darkness, that is, to the lie, so as to be kept until judgement. (Koerbagh 2011, p. 349)

The same reading could fit Jude 6, which states that the "angels" who erred have been kept by God "in eternal chains in the nether gloom until the judgment of the great day". Koerbagh insists that the passage, contrary to what the Christian tradition says, "is not about devils, but about teachers in error". In this way, his interpretation of a demonological passage gives way to a theologico-political diatribe, a secularized demonization indeed: A light shining in dark places uses Jude 6 to pour scorn on the "leaders" of religion, the theologians, who had abandoned the light "and for political gain become seducers instead of leaders". Hence, whereas Jude 6 does not offer "proof of any evil spirit", it gives us "proof of evil human beings" who will be kept by God in darkness, "that is, false teachings" (Koerbagh 2011, pp. 427, 429).

As we can see, although Koerbagh displays a Hobbesian biblical exegesis based on an etymological interpretation of the scriptural evil spirit, his Cartesian metaphysics applied to Revelation seems more radical than Hobbes' materialism, not only rendering the operations of incorporeal spirits impossible, but denying that biblical evil spirits could exist as substances. On the overall subject of the biblical devil, Koerbagh concludes:

Since we have not been able to discover from all the names found in holy scripture that there are such evil spirits as the theologians invent, neither from the book on the origins nor any

9 It is interesting to point out that Koerbagh uses this idea to draw a parallel between him and Jesus: "If someone asks me how I dare consider a friend or acquaintance [of Jesus] as the tempter, I would answer that I read that his friends and those near to him slandered and scolded him, calling him mad and out of his mind. And such things still occur, since it has happened to me that all my friends have slandered and scolded me for being a fool and godless, and the like, though I, O! cruel slander, have never in my life written anything against reason, but have opposed that which is against reason" (Koerbagh 2011, p. 239). As we will see below, Koerbagh thinks that salvation means only to teach others true knowledge; that is, true "rational" religion-that was what Jesus, "the savior", did (Koerbagh 2011, p. 143). 
other place in holy scripture, as has been said and proved, we rightly reject the fabricated evil spirits as well. (Koerbagh 2011, p. 451)

\section{A Light to Unveil Demonic Possession}

If disembodied spirits cannot intervene in the material world, and if scriptural "evil spirits" are non-existent and can be accounted for as inner natural dispositions, inner thoughts, and human enemies, what does Koerbagh think of demonic possession? In a nutshell, the state of possession is related to diseases, extraordinary but natural behavior, and evil thoughts. This interpretation appears in Hobbes' Leviathan, in which every biblical instance of demonic possession is read as a natural process or as metaphor. For example, since "the spirit of man, when it produceth unclean actions, is ordinarily called an unclean spirit", the Scripture may deploy this inclination to evil, metaphorically, as a demonic possession; thus, for example, the "entrance" of Satan in a man could be understood as "the wicked Cogitations, and Designes of the Adversaries of Christ, and his Disciples" (Hobbes 2012, pp. 38, 355). Likewise, as the biblical term "spirit" may stand for an extraordinary bodily passion, such as a mental disease, "Mad-men are said to be possessed with a spirit". Thus, it is clear that the Bible refers to "Mad-men, or Lunatiques" as "Daemoniaques" (Hobbes 2012, pp. 208, 211).

However, let us also note that Leviathan's materialism led Hobbes to deny the possibility of demonic possession precisely because he affirmed the existence of evil spirits: if "incorporeal substance" is an oxymoron, and spirits are bodies, then it is impossible to conceive a substance penetrating another substance. The fact that Hobbes admits spirits as substances explains why he rejects possession:

I have not yet observed any place of Scripture, from whence it can be gathered, that any man was ever possessed with any other Corporeall Spirit, but that of his owne, by which his body is naturally moved (... ). I find that there are Spirits Corporeall, (though subtile and Invisible); but not that any mans body was possessed, or inhabited by them. (Hobbes 2012, pp. 354-55)

Again, although Koerbagh's exegesis admits a Hobbesian naturalization and metaphorization of biblical possession, his metaphysics led him to a far more radical account of this subject. Let us start with his etymological analysis. A light shining in dark places devotes several paragraphs to analyze the Greek word which, in the New Testament, expresses the state of being possessed, daimonizestai. As a derivation of daimon, its meaning could be "being placed among the gods, or being counted as gods, or being turned into a god" (Koerbagh 2011, p. 433). On the other hand, as the word daimon can refer to either a good or a bad spirit, daimonizestai can also mean "being guided by a good spirit as well as being plagued by an evil spirit". This is in line with Koerbagh's preferred meaning for daimon, "the inborn nature of man". Thus, "it is certain that someone with a good nature also has a good soul or spirit, and that one with a bad nature also has a bad soul or spirit". Should someone look for a "reasonably clear explanation" for possession, one would need only to "apply a good spirit to someone's good nature and an evil spirit to an evil nature" (Koerbagh 2011, p. 435).

In this context, a demonic possession could be interpreted through metaphorization and naturalization. Daimonizestai may be read as "being plagued by an evil spirit", because, as Cartesianism shows, spirit is thought, and "thoughts are workings of the mind, that is of the soul". The cause of the suffering, then, is spiritual, but it is internal rather than external: those who are daimonizestai "are not plagued by an evil spirit coming from outside, as the theologians think, but by an evil or defective soul". This, in turn, could be the result of physical impairments, such as "poor constitution of the blood" and "weakness of the brain" (Koerbagh 2011, p. 433). Furthermore, Koerbagh is explicit in the Spinozist equation of God and natura. Because God is the essence of all his modes of being, it could be said that all things_-bodies, thoughts, diseases, events—are God's messengers (Wielema 2003b, p. 74). It seems appropriate, then, to think that "someone is punished or plagued by God" with an evil spirit, because "various diseases with which we are often visited by God are evil spirits, and furthermore all sorts of evil thoughts". In one of his most monistic paragraphs, Koerbagh affirms that daimonizestai can 
be interpreted as "being tortured or plagued by God, namely by madness, insanity, epilepsy, lunacy, or evil thoughts" (Koerbagh 2011, p. 433).

As this state often results in "being out of one's senses", it produces symptoms that are commonly attached to demonic possession. Koerbagh happens to list symptoms found in the Bible, but without mentioning any scriptural passage: being mute and blind (Matthew 9: 33; 12: 22), falling down (Mark 9: 18, 20), not hearing (Mark 9, 25; Matthew 12: 22): ${ }^{10}$

When someone catches one of the described diseases, he becomes so witless or out of his mind that he falls down and does not see or hear, as happens with such afflictions, or so out of his wits that he says strange things which he has no recollection of having said. (Koerbagh 2011, p. 433)

But why is this confusion between demonic possession and natural affliction so common? Here, we may detect Hobbes' influence. Leviathan affirms that ignorance of natural causes led Pagans and Jews to take as possessed people those madmen and lunatiques "or [those] that spoke anything, which they for want of understanding, thought absurd" (Hobbes 2012, p. 353). Koerbagh follows this explanation: "those who were plagued by rage or madness sometimes did and said curious and absurd things for which the common people could not give an explanation or provide a cause" (Koerbagh 2011, p. 437). As his analyses on devils and daimonizestai prove, this cause has nothing to do with diabolical spirits; for Koerbagh, being possessed simply means that one suffers at the hands of natura and of human nature.

Let us see an example of Koerbagh's exegesis concerning a biblical case of possession and exorcism, Matthew 12:22 and 24. He quotes Matthew 12:22: "Then a blind and mute demoniac was brought to him, and [Jesus] healed him, so that the man spoke and saw". He starts by pointing out that daimonizomenos, translated here as "demoniac", comes from daimonizestai, the state of being plagued by evil spirits-i.e., by evil thoughts or physical ailments. The best reading of the passage would be: "Then was brought to him one who was miserable (or crazed) being blind and deaf, or deaf mute" (see note 11 above); and later: "And he cured him so that the blind and deaf mute spoke and saw" (Koerbagh 2011, p. 441).

This opens Koerbagh's discussion on exorcism. Witnessing this cure, the Pharisees thought that Jesus was in league with the devil, who gave him the power to exorcize: "This one does not throw out the devils unless through Beelzebub, lord of the devils" (Matthew 12: 24). Nevertheless, Koerbagh affirms that Matthew 12:22 says nothing about an exorcism:

It does not say "throw out", as is stated in [Matthew 12:] verse 24, as if one could throw out a spirit as a hand throws a stone. Instead, it says here that the Saviour cured the sick or miserable man of his afflictions. (Koerbagh 2011, p. 443)

Koerbagh develops his interpretation of Matthew 12:24 by analyzing the Pharisees' accusation that Jesus exorcized through the power of the devil. The passage, Koerbagh contends, says nothing about "devils": it speaks of daimonian; that is, gods or evil spirits. The reading of the passage should thus be "This does not throw out the evil nature (or deficient nature; that is, deficiencies, namely of people) unless in the lord of the flies, highest (that is helper) of the evil natures". What could this mean? With a keen sense of the importance of history and culture for an adequate interpretation of the biblical text, Koerbagh points at Pagan religious praxis. The heathens used to ascribe a "special god", a "patron helper" so to speak, to every given sickness. Beelzebub, "the lord of the flies", was one of them, "a patron or helper in some mental deficiencies". This was known by the Pharisees, and provided the substance of their accusation to Jesus, i.e., that he was as an impious Jew:

10 Let us point out that Koerbagh stresses that Matthew 12:22 is not about a blind and mute demoniac, but a blind and deaf one: the biblical word "kophos" does not mean "mute", as traditional translations have it, "but deaf, and deaf from birth, which is put together in Dutch in a fine expression, namely deaf mute" (Koerbagh 2011, p. 441). 
Wishing to portray the Saviour (although they knew that he was a Jew) as a heathen and scold him, [the Jews] said in their slander: 'He does not throw out the evil natures (or deficiencies) except in the lord of the flies, chief of evil natures (or miseries, or miraculous things, as the word daimonia can also be interpreted), that is, he helps in the name of an idol (whom the heathens claim to be a helper in several specific troubles or miseries) and not in the name of the true God. (Koerbagh 2011, pp. 439-41)

Since Koerbagh rejects the notion of exorcism (he speaks about the "cure" of a natural affliction), his detailed analysis of the passage betrays an interest in highlighting the cultural context in which the Jews and Christ used to live. The religious practices of the Pagans allowed the Jews to cast Jesus as an idolater, denying him the power to exorcize in the name of God, and instead accusing him of exorcizing in the name of a demon. In this same line, Koerbagh adds, Matthew 12:24 should not be taken as a biblical proof of the existence of demons and the possibility of exorcism, because the Pharisees "did not speak as wise and learned people but as superstitious heathens and Greeks, whose way of speaking they used" (Koerbagh 2011, p. 439). Scripture, then, seems to teach us nothing about metaphysics, but a great deal about the mental world of their authors. In the concluding section, we shall see why this insistence on the culture of the biblical world is crucial to understanding the implications of Koerbagh's denial of demonic possession and demonology.

\section{The Devil, from Sacred Truth to Cultural Heritage}

After this account on the philosophical and exegetical assault on spirits, demons, and demonic possession in the thought of Adriaan Koerbagh, it should be clear why the second half of the XVIIth century provided the most coherent attack on the medieval and early modern idea of the devil that Europe had ever met until that moment. The anonymous 1691 Dutch poet with whom we opened this article was indeed right when he related Balthasar Bekker's De Betoverde Weereld to Thomas Hobbes and Koerbagh. Anyone reading Bekker's work will immediately encounter the same strategies of naturalization, metaphorization, and a critical use of etymology regarding the interpretation of biblical devils and instances of demonic possession. Of course, Hobbes's Leviathan and Bekker's anti-demonological synthesis cannot be compared with Koerbagh's book in terms of actual impact in the debate about devils and demons, given that A light shining in dark places remained an unknown oeuvre for centuries. But that should not deter us from stressing the radical nature of Koerbagh's views on the subject. His biblical interpretation, armed with Greek and Hebrew etymology, natural afflictions, and figures of speech, provided alternative explanations for those key passages concerning demons. This, I think, was developed under an important Hobbesian influence. Nevertheless, whereas Hobbes taught that Revelation commands us to believe in the devil's existence, and that materialism shows us that spirits must be substances_and thus real entities-Koerbagh's definition of spirit entailed the metaphysical impossibility of the existence of the devil and the experience of spiritual possession. Koerbagh's Cartesianism, then, far surpassed Hobbes' materialism; thus, at least from the anti-demonological point of view, radicalism was indeed on the side of the early Dutch Enlightenment.

Thus, we may highlight Koerbagh's role in the intellectual history of the critique of the Christian devil, and his place in the proto-Enlightenment equation between demonology and superstition. Along this line, I wish to employ this last section to entertain a further thought on his perceptions regarding these affinities between superstition and belief in demons. As Wiep van Bunge notes, decades before Bekker entered the early Enlightenment scene, demonic intervention had already been ridiculed as the product of philosophical, theological, and philological error (Van Bunge 1995, p. 50). As may be gathered from what we wrote in the preceding sections, Koerbagh had the intention to extirpate the Christian devil from true religion, thus curtailing the role of demonology in the economy of the sacred. My question here is in which way is this anti-demonological project connected with the Enlightenment gesture towards the secularization of Scripture. In this specific case, I am interested in the overall impact of the naturalistic and historical reading of biblical passages concerning the Enemy, and their relationship (or lack of) with the Christian truth. 
Hobbes is, again, of some importance if we want to understand this. Given that, as we saw, biblical demonic possession is a metaphor or an illness, why did Christ heal as if he was exorcizing demons? Jesus' exorcisms are an example of divine accommodatio: the message that God wishes to convey must be uttered in the language of men, i.e., adapted to their capacities. Thus, Christ commanded "the Madnesse, or Lunacy he cureth" as if they were devils, because people at that time believed that natural afflictions were instigated by evil spirits (Hobbes 2012, p. 354). Does this make Jesus a liar? Why would the Savior, who is the Truth, trick us? All this discussion, Hobbes affirms, is a matter "more curious than necessary for a Christian mans Salvation". To debate the possibility or impossibility of possession is futile. True Revelation tells us that demons exist; nevertheless, the only article of faith that matters for salvation is that Jesus is the Christ, who promises a future Kingdom and immortality for those who believe in him. Thus, "the opinion of Possession by Spirits, or Phantasmes, are no impediment in the way" of salvation; furthermore, it could be a dangerous occasion for men "of going out of the way, and to follow their own Inventions" (Hobbes 2012, p. 355). In addition, Revelation teaches us nothing about natural philosophy: Christ only spoke about the fundamental principles of salvation, "leaving the world, and the Philosophy thereof to the disputation of men, for the Exercising of their natural Reason" (Hobbes 2012, pp. 38-39). Speaking explicitly about demonic possession, Hobbes contends that Jesus left "the search of natural Causes, and Sciences, to the natural Reason and Industry of men" (Hobbes 2012, p. 355). In conclusion, devils, their activities, and our understanding of them are indifferent regarding salvation.

We know that Koerbagh took a more radical turn than Hobbes, claiming that demons were not even part of Revelation. Revelation is not distinct from philosophy: the word of God is not above or against reason; it is reason, and if reason shows that there are not evil spirits as the theologians understand them, then Scripture must reflect this. Indeed, if read without prejudice and according to the literal meaning of the Hebrew and Greek original, the Bible does not support the belief in the existence of the devil (Wielema 2003b, pp. 65-66, 72). After his critical analyses on demons, Koerbagh asks:

Where in holy scripture is there such an explicit commandment as that those who do not believe that there are such fabricated evil spirits as the clergy invent will be forever doomed? Nowhere. (Koerbagh 2011, p. 451)

But we do hear Hobbes loud and clear when Koerbagh discusses the salvational value of belief in demons: devils are not "a matter of importance in which there is any salvation", and on this subject "one can believe or reject it as one chooses". Moreover, Koerbagh's idea of salvation clashes head on with demonology because, for him, salvation consists "in bringing one or many (the more, the greater the saviour) out of ignorance to knowledge, wisdom and understanding" — an interesting hint at the Spinozist moral commandment, "love your neighbor". This is the true "knowledge of God", which allows us to reach "life eternal" (Koerbagh 2011, pp. 143,451). It is safe to say, given what we saw above about Koerbagh's interpretation of biblical evil spirits, that few things are further away from knowledge than the Christian idea of demons.

It seems clear, then, that Hobbes and Koerbagh share the view according to which, even when the Scripture mentions devils (or that which the theologians take for devils), they are not part of the fundamental sacred truth; quite the contrary, they are pernicious if one wishes to search for salvation. Let us go a step further and ask where, according to Hobbes and Koerbagh, did these devils and the belief in them came from in the first place. Leviathan provides an answer: the Pagan worldview. Given that the Pagans misunderstood nature's operations, they posit gods and daemones, invisible and powerful spirits, good or bad, to explain many natural events that they could not comprehend-for example, madness, which they attributed to demonic possession. Now, these Pagan daemones found their way first into Judaism, and then into Christianity (Hobbes 2012, pp. 51, 353). Indeed, says Hobbes, that which the Greeks called "Daemones", the Jews "called Spirits, and Angels, Good or Bad"; not even the Apostles escaped from this: "The Disciples themselves did follow the common opinion of both Jews and Gentiles, that some such apparitions were not Imaginary, but real" (Hobbes 2012, p. 210). These ideas concerning spirits did not change over time; on the contrary, the Christian religion 
inherited "the Daemonology of the Heathen Poets, that is to say, their fabulous Doctrine concerning Daemons" (Hobbes 2012, p. 334). In the hands of the clergy, themselves, part of a "confederacy of deceivers", this pernicious doctrine is still damaging the State and its subjects. And they are deceivers because demonology, that vital remnant of Paganism, is not part of true religion: "Men are the more easily seduced to believe the doctrine of Devils, which at that time was the Religion of the Gentiles, and contrary to that of Moses and of Christ" (Hobbes 2012, p. 244). Leviathan, itself, with its combination of natural philosophy, anthropology, biblical exegesis, and political theory, is Hobbes's attempt to free Christianity and the State from this dangerous belief.

Koerbagh is also explicit in relating Christian demonology to Paganism. The Greeks, "being heathens full of superstition", invented daimones; that is, gods, spirits, and spectres. Christianity took these entities at heart as evidence of the existence of the devil- "if we want to accept the Greek fictions and nonsense, then I admit that the theologians would already have some proof here". Under Koerbagh's eyes, many central elements of traditional demonology are only variations on Pagan themes. For example, the concept of hell derives from the "heathens poets" who, "often like clergy", devised "such terrifying fabrications" - in this case, Hades—in order to "scare the common people away from doing evil". We may expect this fiction, given that the poets of antiquity, "who often or usually took the place of theologians in ancient times", used to invent "many fantasies". Another example: the demonic serpent in the Garden of Eden may also have been of heathen origin. The whole story may come from that "incorrect way of speaking and writing that was quite common among the Egyptian priesthood, from whom Moses learned it and introduced it into the Jewish religion". Finally, and as we saw above, Koerbagh believed that the Pharisees's accusation against Jesus-that he exorcized in the name of Beelzebub - could not stand as proof of the existence of the devil precisely because "those who spoke there did not speak as wise and learned people but as superstitious heathens and Greeks". Indeed, "Greek superstitions" - in this case, the devil-" "also took hold of the Jews" (Koerbagh 2011, pp. 341, 435, 439, 443, 449).

As we may see, Hobbes and Koerbagh strove for the elimination of many central aspects of early modern Christianity, labeling them as "superstitions" and treating them as alien to God's true message. What is truly divine in Scripture- "Jesus is the Christ" (Hobbes), "teach others true knowledge" (Koerbagh) - must be isolated from what is strictly the product of human invention. Pagan and Jewish languages and figures of speech, their legends and stories, and above all their ignorance of natural law and metaphysics, have swaddled the simple sacred message in layer after layer of philosophical, theological, and scientific error, i.e., in superstition. This has not been corrected by Christianity as organized religion; quite the contrary, theologians strengthened these errors. It is the mission of the true philosopher and the true Christian to rediscover the divine truth. This, I think, is what Koerbagh, and Hobbes before him, aimed at.

This fits well with Koerbagh's discussion on the biblical devil and the scriptural instances of demonic possession. For him, the early modern idea of the Christian devil rests on Jewish and Pagan superstition; etymology, metaphors, evil thoughts, human enemies, and shared erroneous beliefs about metaphysics and natural laws in the biblical world could better explain those passages mentioning demons and possession. For Koerbagh, and here he departs from Hobbes, this explanation entails that devils do not exist at all, that they are indeed "fictitious evil spirits". As we may conclude, in a process that could be referred to as the secularization of the biblical devil, late XVIIth-century anti-demonologies like the one advanced by Adriaan Koerbagh turned what once was a part of a sacred truth into a fragment of a human—and thus a feeble, transitory, and changeable—cultural heritage.

Funding: This research received no external funding.

Conflicts of Interest: The author declares no conflict of interest. 


\section{References}

Anonymous. 1691. De Betoverde Weereld van den Hooggeleerden Heer, Dr. Balthasar Bekker, Door de Geestelykheit bevogten. In Verscheyde Gedichten, Soo voor, als Tegen het Boek, Genaamt: De Betoverde Weereld. Gedrukt: Voor de Liefhebbers.

Attfield, Robin. 1985. Balthasar Bekker and the decline of the Witch-Craze: The old demonology and the new philosophy. Annals of Science 42: 383-95. [CrossRef] [PubMed]

Bath, Jo, and John Newton. 2006. 'Sensible Proof of Spirits': Ghost Belief during the Late Seventeenth Century. Folklore 117: 1-14. [CrossRef]

Cameron, Euan. 2010. Enchanted Europe: Superstition, Reason, and Religion, 1250-1750. Oxford: Oxford University Press.

Champion, Justin. 2012. 'The Kingdom of Darkness': Hobbes and Heterodoxy. In The Intellectual Consequences of Religious Heterodoxy 1600-1750. Edited by Sarah Mortimer and John Robertson. Leiden: Brill, pp. 95-120.

Del Olmo, Ismael. 2018. Against Scarecrows and Half-Baked Christians: Thomas Hobbes on Spiritual Possession and (Civil) Exorcism. Hobbes Studies 31: 127-46. [CrossRef]

Fix, Andrew. 1989. Angels, Devils, and Evil Spirits in Seventeenth-Century Thought: Balthasar Bekker and the Collegiants. Journal of the History of Ideas 50: 527-47. [CrossRef]

Fix, Andrew. 1999. Fallen Angels: Balthasar Bekker, Spirit Belief, and Confessionalism in the Seventeenth-Century Dutch Republic. Dordrecht: Kluwer Academic.

Gijswijt-Hofstra, Marijke, Brian P. Levack, and Roy Porter, eds. 1999. The Athlone History of Witchcraft and Magic in Europe: The Eighteenth and Nineteenth Centuries. London: Athlone Press, vol. 5.

Hobbes, Thomas. 1928. The Elements of Law: Natural and Politic. Edited by Ferdinand Tönnies. London: Cambridge University Press.

Hobbes, Thomas. 2012. Leviathan. Edited by Noel Malcolm. Oxford: Clarendon Press, vol. 3.

Israel, Jonathan. 1996. The Bekker Controversies as a Turning Point. Dutch Crossings 20: 5-21. [CrossRef]

Israel, Jonathan. 2001. Radical Enlightenment: Philosophy and the Making of Modernity 1650-1750. Oxford: Oxford University Press.

Jobe, Thomas. 1981. The Devil in Restoration Science: The Glanvill-Webster Witchcraft Debate. Isis 72: 342-56. [CrossRef]

Jongeneelen, Gerrit. 1991. La Philosophie Politique d'Adrien Koerbagh. Cahiers Spinoza 6: 247-67.

Koerbagh, Adriaan. 1668. Een Bloemhof van Allerley Lieflijkheid Sonder Verdriet Geplant door Vreederijk Waarmond Ondersoeker der Waarheyd. Amsterdam: n.p.

Koerbagh, Adriaan. 2011. A Light Shining in Dark Places, To Illuminate the Main Questions of Theology and Religion. Edited by Michiel Wielema. Leiden: Brill.

Lilti, Antoine. 2009. Comment écrit-on l'histoire intellectuelle des Lumières? Spinozisme, radicalisme et philosophie. Annales. Histoire, Sciences Sociales 64: 171-206.

MacMillan, Alissa. 2014. Exorcizing Demons: Thomas Hobbes and Balthasar Bekker on Spirits and Religion. Philosophica 89: 13-48.

Malcolm, Noel. 2002. Aspects of Hobbes. Oxford: Clarendon Press.

Nadler, Steven. 2011. A Book Forged in Hell: Spinoza's Scandalous Treatise and the Birth of the Secular Age. Princeton: Princeton University Press.

Salatowsky, Sascha. 2017. Socinian Headaches: Adriaan Koerbagh and the Antitrinitarians. In The Dutch Legacy: Radical Thinkers of the 17th Century and the Enlightenment. Edited by Sonja Lavaert and Winfried Schröder. Leiden: Brill, pp. 165-203.

Schaffer, Simon. 1985. Occultism and Reason in the Seventeenth Century. In Philosophy: Its History and Historiography. Edited by Allan Holland. Dordrecht: Reidel Publishing, pp. 117-43.

Spinoza, Baruch. 1995. The Letters. Edited by Steven Barbone, Lee Rice and Jacob Adler. Indianapolis: Hacket Publishing Company.

Spinoza, Baruch. 2002. Complete Works. Edited by Michael Morgan. Indianapolis: Hackett Publishing Company. Spinoza, Baruch. 2007. Theological-Political Treatise. Edited by Jonathan Israel. Cambridge: Cambridge University Press. Springborg, Patricia. 2004. The Enlightenment of Thomas Hobbes. British Journal for the History of Philosophy 12: 513-34. [CrossRef] 
Van Bunge, Wiep. 1995. Eric Walten (1663-1697): An Early Enlightenment Radical in the Dutch Republic. In Disguised and Overt Spinozism Around 1700: Papers Presented at the International Colloquium, Held at Rotterdam, 5-8 October 1994. Edited by Wiep van Bunge and Wim Klever. Leiden: Brill, pp. 41-54.

Van Bunge, Wiep. 2000. Du Betoverde weereld au Monde enchanté. Traces de Bekker dans les premières Lumières françaises. In Materia Actuosa. Antiquité, âge classique, Lumières. Mélanges en l'honneur d'Olivier Bloch. Edited by Antony Mckenna, Miguel Benítez, Gianni Paganini and Jean Salem. Paris: Honoré Champion, pp. 453-71.

Van Bunge, Wiep. 2001. From Stevin to Spinoza: An Essay on Philosophy in the Seventeenth Century Dutch Republic. Leiden: Brill.

Van Bunge, Wiep. 2011. Introduction. In A Light Shining in Dark Places, To Illuminate the Main Questions of Theology and Religion. Edited by Michiel Wielema. Leiden: Brill, pp. 1-38.

Van Ruler, Han. 2000. Minds, Forms, and Spirits: The Nature of Cartesian Disenchantment. Journal of the History of Ideas 61: 381-95. [CrossRef]

Vermeir, Koen. 2013. Mechanical Philosophy in an Enchanted World: Cartesian Empiricism in Balthasar Bekker's Radical Reformation. In Cartesian Empiricisms. Edited by Mihnea Dobre and Tammy Nyden. Dordrecht: Springer, pp. 275-306.

Waite, Gary. 2018. Knowing the Spirit(s) in the Dutch Radical Reformation: From Physical Perception to Rational Doubt, 1536-1690. In Knowing Demons, Knowing Spirits in the Early Modern Period. Edited by Michelle Brock, Richard Raiswell and David Winter. Cham: Palgrave Macmillan, pp. 23-54.

Wielema, Michiel. 2001. The Two Faces of Adriaan Koerbagh. Geschiedenis van de Wijsbegeerte in Nederland 12: 57-75.

Wielema, Michiel. 2003a. Adriaan Koerbagh. In The Dictionary of Seventeenth and Eighteenth-Century Dutch Philosophers. Edited by Wiep van Bunge, Henri Krop, Bart Leeuwenburgh, Han van Ruler, Paul Schuurman and Michiel Wielema. Bristol: Thoemmes Press, pp. 571-74.

Wielema, Michiel. 2003b. Adriaan Koerbagh: Biblical Criticism and Enlightenment. In The Early Enlightenment in The Dutch Republic, 1650-1750. Edited by Wiep van Bunge. Leiden: Brill, pp. 61-80.

Wielema, Michiel. 2004. The March of the Libertines: Spinozists and the Dutch Reformed Church (1660-1750). Hilversum: Uitgeverij Verloren.

Wielema, Michiel. 2017. Abraham van Berkel's Translations as Contributions to the Dutch Radical Enlightenment. In The Dutch Legacy: Radical Thinkers of the 17th Century and the Enlightenment. Edited by Sonja Lavaert and Winfried Schröder. Leiden: Brill, pp. 204-26.

(C) 2019 by the author. Licensee MDPI, Basel, Switzerland. This article is an open access article distributed under the terms and conditions of the Creative Commons Attribution (CC BY) license (http://creativecommons.org/licenses/by/4.0/). 


\title{
"Charming Sorcerers" or "Soldiers of Satan"? Witchcraft and Magic in the Eyes of Protestant/Calvinist Preachers in Early Modern Hungary ${ }^{\dagger}$
}

\author{
Ildiko Sz. Kristof \\ Institute of Ethnology, Research Centre for the Humanities, Hungarian Academy of Sciences, Budapest 1097, \\ Hungary; ildiko.szkristof@gmail.com \\ † The present study is the translation of Chapter 3 of my book entitled "Ördögi mesterséget nem cselekedtem." \\ A boszorkányüldözés társadalmi és kulturális háttere a kora újkori Debrecenben és Bihar vármegyében \\ ("I have not done any diabolic deeds." The Social and Cultural Foundation of Witch-Hunting in Early Modern \\ Debrecen and Bihar County) published in Debrecen (Hungary) in Hungarian in 1998. The book examines the \\ witch-hunting in Bihar county and its largest city in Eastern Hungary between 1575 and 1766. During this \\ period, 217 trials were conducted against 303 accused, and my study explores the social and religious \\ foundations of the accusations. The witch-hunts in Bihar county were of rather small size (1-3 accused \\ per annum) and intensity (only $32 \%$ of the trials concluded in death sentence). A possible explanation for this \\ relative mildness could be provided in my view by a complex consideration of legal, religious, and local social \\ circumstances. Chapter 3, published here in English, discusses Hungarian Calvinist demonology which \\ remained rather sceptical about the concepts of diabolical witchcraft. Consequently, the magistrates of \\ Debrecen and Bihar county were not inclined to identify masses of witches, alleged representatives of \\ a sect directly associating with the devil. The text is a result of a thorough archival exploration that I carried \\ out twenty-one years ago in the special collections of various libraries in Budapest. I still find the conclusions \\ included in it relevant and sound, so I decided to leave the argumentation as it was in 1998. I am grateful to \\ Gyöngyvér Horváth PhD for the English translation. Chapter 5 of the same book on the macro- and \\ micro-scale social contexts of local witch-hunting is also available in English, see (Sz. Kristóf 2017; \\ an earlier version Kristóf 1991/1992). For a survey of the research of witchcraft and witch persecution in \\ Hungary in general, see (Sz. Kristóf 2013), mentioning further details about Debrecen and Bihar county \\ witch trials.
}

Received: 13 April 2019; Accepted: 28 April 2019; Published: 16 May 2019

\begin{abstract}
The present study is the translation of Chapter 3 of the book of Ildikó Sz. Kristóf, entitled “Ördögi mesterséget nem cselekedtem." A boszorkányüldözés társadalmi és kulturális háttere a kora újkori Debrecenben és Bihar vármegyében ("I have not done any diabolic deeds." The Social and Cultural Foundation of Witch-Hunting in Early Modern Debrecen and Bihar County) published in Debrecen, Hungary in 1998. The book examined the witch-hunting in Bihar county and its largest city, the headquarters of the Calvinist church in Eastern Hungary between 1575 and 1766 . During this period, 217 trials were conducted against 303 accused, and the book explored the social and religious foundations of the accusations. The witch-hunts in Bihar county were of rather small size (1-3 accused per annum) and intensity. A possible explanation for this relative mildness could be provided by a complex consideration of legal, religious, and local social circumstances. Chapter 3, published here in English, discusses Hungarian Calvinist demonology which remained rather sceptical about the concepts of diabolical witchcraft (e.g., the "covenant" or pact with the devil, the witches' attendance at regular meetings (sabbath), etc.) throughout the early modern era. The author has studied several Calvinist treatises of theology published between the late 16th and the early 18th century by the printing press of Debrecen, those, for example, of Péter Mélius (1562), Tamás Félegyházi (1579), Péter Margitai Láni (1617), János Kecskeméti Alexis (1621), Mátyás Nógrádi (1651), Johannes Mediomontanus (1656), Pál Csehi (1656), István Diószegi Kis (1679; 1681), Gellért Kabai Bodor (1678) and Imre Pápai Páriz (1719). According to her findings, Calvinist demonology, although regarded the wordly interventions of the devil of limited scope (excepting, perhaps, the Puritans of the
\end{abstract}


1650s/1680s), urged the expurgation of the various forms of everyday magic from urban and village life. The suspicion of witchcraft fell especially on the practitioners of benevolent magic (popular healers/"wise women", midwives, fortune-tellers, etc.) who were presumed to challenge and offend divine providence. The official religious considerations sometimes seem to have coincided with folk beliefs and explanations of misfortune concerning, among others, the plague epidemic in which witchcraft played an important role.

Keywords: Protestant demonology; Calvinist demonology in Hungary; witch-hunting in Hungary; witch-hunting in Debrecen/Bihar county; popular/vernacular magic in Hungary; witchcraft and sorcery in Hungary

Members of the clergy belonging to various Christian denominations contributed to the elaboration of demonological concepts such as the witches' alliance with the devil, their attendance at the witches' sabbath, and their harm caused in various ways to their community. As is well known, one of the earliest "hammer of witches", the Malleus maleficarum (1486) was the work of two inquisitors of the Dominican order. During the 16th and 17th centuries, lawyers, doctors, and even kings, such as King James I, ruler of England and Scotland, took part in the discussion about Christian demonology. The early modern churches, even though they had to renounce their right to judge witchcraft cases so that the majority of such cases would be brought before secular courts from the 16th century, maintained a considerable influence on the determination of the nature of that " $\sin ^{\text {" and the principles }}$ of its judgement for a long time. They provided legitimate descriptions of the nature of witchcraft in the religious worldview of the early modern era.

The Reformed church regarded the secular magistrates as the executor of God's will and placed the biblical penal law above the secular ordinances. The judgement of witchcraft, based on the divine law, was of great importance in the criminal forums of the city of Debrecen and the surrounding Bihar county in Hungary, areas whose witchcraft persecution has been investigated thoroughly by the author of the present study. The city spared neither money nor efforts to make the Lex Politica Dei (Lipsiai 1610) available beyond the Bible.

It is a widespread belief in Hungarian scholarship that there was no demonological literature in that country; that is, there were no manuals propagating the elements of the scholarly image of demonic witchcraft (Klaniczay 1986, p. 282; Makkai 1981; and to some extent (Schram 1982, vol. 3, p. 68)). In my view, however, this belief needs to be corrected in many respects-according to both the latest interpretations of Protestant demonology and my own archival explorations. On the one hand, a few shorter and longer works focusing on the subject of witchcraft are known from Protestant authors in Hungary, such as the Lutheran Péter Bornemisza's Ördögi kísirtetekröl (The temptations of the devil) in his five-volume collections of sermons (1579); Péter Melius's treatise, published as an appendix of his so called Debreceni hitvallás (Confession of Debrecen, 1562); or the chapters on the devil's practices in the Puritan Mátyás Nógrádi's collection of preachings, entitled Lelki Probakó (Spiritual touchstone, 1650) (Bornemisza [1579] 1980; Melius 1562; Nógrádi 1651). On the other hand, the fact that these works seem to reflect on the effect of diabolical witchcraft only in a limited way, and therefore can hardly be regarded as belonging to the scholarly literature of demonology, has to be re-evaluated in the light of recent research, primarily that of Stuart Clark and William Monter.

According to Stuart Clark, Protestantism, due to its internal belief system and the practical activities of the preachers, elaborated a special Protestant demonology, which, in its main features, seems to be distinct from the corresponding Catholic ideas. The Protestant approach, which bestowed an exclusive role upon the divine providence, considered the power and activity of the devil to be rather limited. Because the "hands" of Satan were so tightly bound, Protestantism, as Clark argues, was not really concerned with the ways and details of his evil deeds. His operation was regarded to be dependent on God's will in all its aspects, and therefore was considered illusory. As a consequence, 
the activity of witches, the alleged allies of the devil, was not discussed by the Protestants with such an emphasis as it was by their Catholic colleagues. The devil was thought to make witches believe that they can do harm - an argument both Luther and Calvin stressed upon. However, he was also thought to betray them just as he betrays any other Christian mortals.

Accordingly, the argument goes, Protestant demonology can hardly be regarded as a specific genre. It has emerged mainly from the traditional practices of exegesis, and it may turn up in any dissertation, treatise, or preaching that uses examples relying on the parts of the Bible that deal with the power of the devil.

Clark's second argument is that the absolutization of the divine providence prevented the inclusion of positive (intentionally benevolent) magic in Protestant belief, and apparently diabolized it. Those who wanted to heal with magical means or wanted to know the future, and even those who turned to them for help, were almost automatically regarded as persons not trusting enough in the power of God, the guardian of allness. Only the tempting devil could suggest such thoughts. Thus, if a healing was accomplished or a prophecy came true, the Protestants tended to attribute it to the devil.

In Stuart Clark's opinion, the internal logic of Protestantism could have been the reason that in the areas that embraced this religion, in England, for example, the accusations of witchcraft were mostly directed at traditional folk magic experts; and further, that the ideas about witches being in an alliance with the devil or attending the witches' sabbath, were not prevalent. On the other hand, preachers, wishing to transform contemporary folk culture, to purify and reform it according to their religion, focused on all kinds of magical procedures present in the everyday life of their flock. They condemned magic strictly, if not even more harshly than they condemned harmful witchoraft also present in contemporary folk beliefs (Clark 1990, pp. 45-81; Monter 1976, pp. 30-31). ${ }^{1}$

As we will see below, the ideas about witchcraft of those Protestant/Calvinist preachers who were working in the area of Bihar county, East Hungary, strongly support Stuart Clark's arguments. These ideas can be traced in detail in the publications of the printing press in Debrecen, the biggest city of the county and the headquarters of Calvinism in Hungary. Péter Melius (1532-1572), who possibly played the greatest role in the consolidation of the Calvinist reformation in Hungary, came to Debrecen in 1558 as an associate pastor and, as early as 1561, he was elected as a bishop of the Tiszántúl Region Diocese. He kept the position of Debrecen's first pastor until his death in December 1572. He has published several sermons, ceremonial books, catechisms and psalmbooks, a translation of the New Testament, and a herbarium, a treatise on plants and herbs, a popular genre of the era (Szúcs 1871, vol. 2, pp. 542-53; Makkai 1984, pp. 505-11). For his opinion on witchcraft, the most important publication of his oeuvre is the Confessio Ecclesiae Debrecinensis, which he wrote in 1561, together with György Ceglédi (?-1584) and Gergely Szegedi (1536-1566), pastors from Nagyvárad and Debrecen, respectively. The book, commonly known as the Confession of Debrecen, was published in 1562. It has established the dogmas of the Calvinist reformation; in addition, several sections of it deal with the problem of witchcraft (Kiss 1882, pp. 68-284). In the "Dedication", the authors explain their motivation in including this issue in their work. The argument here supports my assumption that the problem of witchcraft in the 1560s did not exist only at a theoretical level in Debrecen. As Melius and his co-authors describe, "Many souls were perplexed due to the malicious opinions about ghosts, witches and infestations ... They called us out inappropriately and flooded us with all those questions that we wrote here, and even our own relatives urged us with arguments in order to openly bring forward these conflicts and overcome the controversies over these issues, because there were only few who were contacted with these issues and could answer according to the same manners and principles. Therefore, our good reader, do not think that we put this down in a flurry" (Op. cit., p. 76).

The historian László Makkai considers Péter Melius's ideas about witchcraft to be surprisingly progressive in the preacher's age (Makkai 1981, p. 127). Essentially, Melius's thoughts can be divided

1 See also (Clark 1997), which was unfortunately not available when I submitted the book to the editors. 
into two groups. The first could be summarized under the title of 'the limited power of the devil and the witches'. The second includes the condemnation of those magical practices that Melius attributed to the power of the devil. According to him, the practitioners of these procedures and those who turn to them would be possessed by the Satan. Let us first turn to his previous group of ideas.

The problem of witchcraft is treated by Melius as "a matter of nature rather than of faith". It is possible that when he speaks of "this evil that may have been wickedly and wrongly given to the people as Satan's works", he condemns the position of the Catholic religion (Kiss 1882, p. 76). According to the Protestant approach, Satan can only act with the permission of God: "neither the wicked or any other creature can be harmed by the devils bound with the strings of hell without divine motivation and heavenly power," says Melius (Op. cit., p. 91). One of the most important deliminations of Satan's activity in the preacher's train of thoughts is the following: "The devils ... are not able to take on real functional bodies or bodies united with souls ... they are unable to engage with the sexes" (Op. cit., p. 228). This position fundamentally questions the idea that the devil appears in an animal or human form on witches' sabbath or is able to have intercourse with witches. When Melius discusses the belief about the incubus [lidérc], he says directly that "the satan ... is not able to spread his seeds or mix them, because it has no organic body. It is believed that ejaculation means getting into a relationship with the satan, even though it is against the nature of the devil" (Op. cit., p. 229).

The act of squeezing/pressing [megnyomás] and conjurating/giving an evil eye [igézés; szemmel verés] attributed to witches were explained by Melius in a rational way. He describes witches' harm as a kind of illness. When someone, he says, lies on his/her back for a long time, "the lungs become compressed, and the vital force (spiritus vitalis) recedes from the end of the nerves and goes under suppression and ceases." In all these processes, the devil and the witches could only have a limited role, as he says, "the compressed brain fabricates images about the burden that weighs it down." To cure, he recommends bloodletting, purgation, and "remedies for thick humours" (Op. cit., p. 284). According to his opinion, conjuration/evil eye is also an illness, which goes hand in hand with atrophy, "weight loss and delusions", and has a natural cause. Therefore, as he says, "that babies and others can be bewitched, sickened or dried by looking, feeling, praising, is evil speech." Once again, Melius's phrasing suggests that this question could have had a practical significance at the time his work was written, because, as he noted, "pastors are being asked about these issues frequently". With his opinion on conjuration/evil eye, he wished to provide a guidance for both the pastors, "whose answers often evoke a laughter and give opportunity to a little foolery", and the "nosy news eater and imaginative" members of the congregation in order to get rid of this "evil superstition" (Op. cit., pp. 229-30).

In Melius's text, it is a recurring argument that the devil and the witches under his leadership rarely harm the "pious", but they rather tease the "evil" with the consent of God. Behind this argument stands one of the most frequently mentioned statements of the Calvinist literature published in the 16th and 17th centuries in Debrecen, that the troubles and misfortunes penalize primarily those who transgress godly life, and God punishes those who turn away from him with his own means, that is, the devil. When bringing misfortune, God, however, only tests the "pious", such as Job of the Old Testament, for the strength of their faith. Therefore, everyone should look for the cause of their troubles in themselves. In connection with the belief about the incubus [lidérc], which he interpreted as an "infection with ejaculation", Melius expresses directly that this is "the Lord's whip, who punishes the sin of lust with the desire of lust." The main antidote to God-sent troubles is turning away from sin and keeping penance. Apart from "controlling drugs", the "illness" of the incubus, according to Melius, can be healed with "fasting and praying, that is, with true penitence" (Op. cit., p. 229).

Now, we will turn to the second group of his thoughts. There was a widespread Protestant view, shared by both Luther and Calvin, that the "miracles" of Satan and his allies, witches or magicians, are not real and are merely illusions. This is not so obvious at Melius. In the section on "night ghosts, witches, wandering souls, or squeezers/pressers [megnyomók]", he says, for example, "Undoubtedly, when [the incredulous] get into the hands of satan, the satan does miracles by [using] them as they would be his own [fellows], not deceptively but truly, just as he would do through sorcerers. With the 
Lord's permission he reveals the signs beforehand and the coming [events], as he predicted, would happen." He claims elsewhere that "it is certain that witches, night ghosts, and stray souls are controlled by the devil, and are led to evil. They are capable of entering houses, shops and other fortresses, not by penetrating bodies or openings, but the devil creates ways to his own [fellows] by his own methods." Moreover, according to Melius, the devil "is able to pick up the whole man with his flesh and soul and take him wherever he wants, and [does this] with the consent and agreement of God" (Op. cit., p. 228). Strikingly, when he speculates on squeezing/pressing, conjurating/evil eye, and on the incubus [lidérc], he explains, as we have seen, the limited power of the devil, but at the same time he always makes references to what extent this power is not limited. It should not be questioned, he writes, that the devil actually tortures people, "ties them, fools them, or cripples them in various ways through his sorcery". And if the looks and praising words of nurses and witches cannot hurt little children, their "poison and harmful touchings" can (Op. cit., p. 229).

Finally, the most important part of the second group of Melius's thoughts is what we could summarize with the preacher's own words: "we believe that delusion, sorcery, prophecy from inspecting dead bodies, or palm reading are the work of satan" (Op. cit., p. 228). The reasoning behind this statement reveals the position of Protestantism in condemning even the positive or benevolent magic. Apart from two exceptions, measurement-based sorcery [méréssel történó varázslás] and astrology [csillagjóslás], Melius did not refer to the magical practices of his own age, but the cases of sorcery mentioned in the Bible. However, he still considers his argument to be valid in his era. According to Melius, when one makes predictions for the purpose of finding out future fortune or misfortune, which is otherwise within the scope of divine providence, he reveals the weakness of his faith, violates the Supreme God, and lets the devil into his soul. Such prophecy is strictly prohibited by Melius. Astrology is likewise forbidden, because, as he says, in this case "our life and our progress" is tied to "silent stars"; with this, we become idolaters, and the devil's booty. According to him, fortune telling is allowed when it is done "free of superstition" [babona nélkül], and merely for the purpose of decision-making in "doubtful cases". However, the preacher does not specify the boundaries between the doubtful cases and predicting the vicissitude of fortune. Therefore, practically any prophecy may fall into the demonic category (Op. cit., pp. 230-31, 275).

To sum up, Melius both narrows down and extends the concept of "demonic witchcraft." It narrows down in a sense that evil actions cannot be performed without the permission of God and also because he attributes different spiritual and material nature to the devil and the humans, with which he excludes even the possibility of fornication between the witches and the bodily form of the devil. This idea was actually the most widespread commonplace idea of Western demonology. Further, it narrows down because he explains few-but only a few-beliefs of his era in a rational way. At the same time, Melius does not deny that the devil and the witches are able to harm people in other ways, for example, that they can intrude their houses, or can kidnap humans; he asserts that these actions are not phantasmagoric. With labelling the practices of positive magic as "demonic", he indeed extends the content of this notion.

It would be difficult to determine which group of thoughts was more significant to Melius. Considering his meticulous treatise on the power of the devil, the two areas, the operational territory of Satan and its limitations, were certainly intertwined. It is much more important that during his more than ten-year stay at Debrecen there were no witchcraft-related trials at the court. The executors of the "divine law" seem to have embraced the first group of Melius's thoughts. Although his teachings about the evil eye and the nightmare (squeezing/pressing) did not abolish these ideas from the popular belief of Debrecen, as László Makkai thought (Makkai 1981, p. 127)², it is possible that in Melius's era

2 His opinion according to which such beliefs would not occur again in the witch trials after the age of Melius is contradicted by the documents of the trials themselves. See chapter 4 of my book. (Kristóf 1998). 
the magistrates had treated such cases according to his intentions; that is, they were not willing to start legal cases in such situations.

Apart from the Church fathers and the Bible, Melius referred only to Luther in the witchcraft-related sections of the Confessio. However, we can list some of the thinkers who have influenced his studies and the evolution of his convictions, and who themselves discussed the subject of witchcraft. In the academic year of 1556/1657, Péter Melius studied at the university of Wittenberg, which was associated with Luther's ideas (Bucsay 1985, p. 64.; Szúcs 1871, vol. 2, pp. 549, 552). He could not study under Luther himself, but he did attend the lectures of Philippe Melanchton (1497-1560). Niels Hemmingsen (1513-1600), a Danish Lutheran and a disciple of Wittenberg and Melanchton, published a dissertation in 1575 in Copenhagen with the title Admonitio de superstitionibus magicis vitandis. It is worth juxtaposing some of its observations with the second group of Melius's thoughts.

In Hemmingsen's opinion, people use both malicious and positive or benevolent magic at the suggestion of the devil, and their effectiveness also depends on him irrespectively of whether there was an obvious alliance with him or not. The practitioners of positive magic turn their backs to God just as the practitioners of malicious magic, as he says, "their belief is not firm, they reject God's choices, leave the fear of God, ignore God's commandments, question his heavenly word, and disobey the requirements of Christian patience". The ultimate conclusion of Hemmingsen's treatise is that pastors should eliminate the popular belief that the sins of the practitioners of positive magic count less than that of the malicious magic, including witchcraft. Hemmingsen's treatise is based on the text of Book V of Moses, the Deuteronomy: "Let no one be found among you who sacrifices their son or daughter in the fire, who practices divination or sorcery, interprets omens, engages in witchcraft, or casts spells, or who is a medium or spiritist or who consults the dead" (18: 10-11) (See Clark 1990, pp. 55, 67-68).

Hemmingsen and Melius both condemned benevolent magic and considered it as "demonic", and they did it in a rather similar way. This coincidence was probably due to the intellectual atmosphere of the university of Wittenberg, a place that had a definitive role on their education. Similarly, we may suspect an indirect influence, perhaps also that of the university of Wittenberg, when we place side by side Melius's opinion on the different nature or the structure of man and the devil and a statement of Johann Weyer (1515-1588), a Lutheran humanist, published in his treatise De praestigis daemonum in 1563. Weyer was a court doctor of William, the Duke of Jülich-Clèves-Berg (1516-1592). He has written a treatise against the witch hunts, in which he mocked the notion of the devil's pact, arguing that the devil, having no material body, could not even give his hand to the witches wishing to form an alliance with him (Trevor-Roper 1969, pp. 73-75; Baxter 1977, pp. 53-54).

Two thinkers might have influenced Péter Melius more directly when forming his opinion: the Lutheran Johann Brenz (1499-1570) and the Calvinist Heinrich Bullinger (1504-1575). Undoubtedly, they had an impact on the evolution of his theology; it is right to assume that Melius not only knew their opinion on witchcraft but used it as a source (Bucsay 1985, p. 64).

Heinrich Bullinger, a reformer from Zurich, published his opinion about the "black art" (Schwartze Künst) in 1586, well after Melius's death; however, his thoughts were evidently formed earlier. It is possible that Melius's argument, according to which God gives power to the devil and through him the witches in order to punish those who have turned away from pious life, and further, to test the faith of the "pious", was partly influenced by Bullinger's similar ideas. Unlike Calvin, neither Bullinger nor Melius came to the conclusion that witches, the "tools" of God's wrath, should be punished. Both Melius and Bullinger agreed that the only way to avert troubles is to practice penitence and return to God (Clark 1990, p. 61).

Johann Brenz, a Lutheran preacher from Tübingen, developed his opinion on witchcraft during the 1520s and 1530s. Several elements of his system of thoughts seem to correspond with that of Melius's. Brenz was one of the first representatives of the Lutheran preachers' tradition in southwestern Germany, which, according to Eric Midelfort's analysis, questioned the belief in witchcraft on the basis of the laws laid down in the Canon episcopi, a 10th-century collection of medieval canon law (Midelfort 1972, pp. 30-36). A passage from the Canon episcopi, which originated as early as the 9th 
century, has strictly condemned that some "evil women ... misled by the delusion and phantasm of the demons believe and openly admit that during the night they ride various animals with Diana, the pagan goddess and countless other women, and in the tranquillity of the silent night they travel to distant lands, and they obey the commands of [Diana] as if she were their goddess, and on certain nights they are bound to serve her". This belief has originated from the ancient Roman, and especially German, concepts of the so called strigae, who were women during daytime but transformed into birds in the night, kidnapped children, and were sucking people's blood. The Carolingian legislation has already labelled the belief in nightly female witch-like demons as paganism and condemned it. According to the Canon episcopi, this belief comes from nothing else than the illusions created by the Satan, and is extremely dangerous, because "deluded by this misbelief, many people consider these things to be true, and when they turn away from true faith and return to the deviations of the pagans, they suppose that there is some divine power beyond the one and only God" (Cohn 1994, both citations are from p. 263).

When Johann Brenz discussed the cause of hail and storms at the beginning of the 16th century, he relied on similar arguments as the authors of canon law. As he writes, hail is sent by God as a punishment to people, and is not, as the popular belief holds, caused by witches. However, some "witches" still think that it is induced by their magical practices; the delusion of the devil stands behind this idea. Satan can become aware of God's intentions, says Brenz, and may suggest to the witches when to begin their practices. This way, the foolish women are deluded, just like the supposed followers of Diana, and eventually they might believe that they are capable of performing such magic (Midelfort 1972, p. 37). To argue this way, Brenz obviously had to extend the devil's power and his range of activity; this is where a common point of his thoughts and that of Melius's is apparent. As was said previously, the devil, according to Melius, anticipates the future, and is able to see into God's intentions; perhaps this is why he emphasizes that the devil's "miracles" are not always delusions. As a consequence, and both Brenz and Melius agreed on that, witches alone have no power (Op. cit., p. 38). Neither at Brenz nor at Melius appear the concept of the orgiastic witches' sabbath, or the pact with the personalized devil. In the case of Brenz, this is obviously due to the impact of the tradition of canon law.

As was mentioned earlier, Melius, who perhaps had been influenced by Johann Weyer in this question, regarded the ability of the devil, as a spiritual being, to incarnate into a material body as impossible. However, we might venture on the idea that the interpretation of witchcraft in canon law could also have had an impact on Melius's system of thought, whether through Brenz or directly. A 12th-century Hungarian law, the First Decree of Coloman, the Learned [Kálmán Könyves] (1070-1116) King of Hungary, seems to have been written in the spirit of the Canon episcopi. It stated that strigae, that is, blood-sucking nightly female demons do not exist; however, at the same time, it has put in order that maleficae, that is "maleficent (female) persons", that is, ordinary people who practice magic, should be punished ((Magyar Törvénytár/Corpus juris hungarici 1000-1526 1899, pp. 112-13)). ${ }^{3}$ We might recall that Melius regarded certain beliefs as superstition, condemned them, and tried to explain them in a reasonable way, while he did not doubt the effect of certain magic practices and saw the devil's contribution behind them. He rejected the concept of nightly squeezing/pressing witches and the belief in incubus [lidérc]. Therefore, he labelled exactly those concepts as superstition that correspond with the belief about mischievous, nightly flitting demons, which had been doubted by both the Carolingian laws and the Canon episcopi. When he speaks about the impossibility of conjuration [igézés], it seems that he is using the phrases of Brenz and the Canon episcopi: "the Satan tricks the wicked with his delusions and seduces them in order to believe the lie but not the truth" (Kiss 1882, p. 230). At the same time, just as the law of Coloman the Learned, he condemned those who perform magical practices.

3 King Kálmán Könyves § I. 57: “De strigis vero quae non sunt, nulla questio fiat."; § I. 60: "Malefici per nuncium archidiaconi et comitis inventi, judicentur." 
Finally, the thoughts of Melius and Brenz are similar in a way that, in contrast to popular belief. Both regarded the main cause of illness, misery, or misfortune as a result of God's punishing anger or testing intentions; according to both authors, ceasing troubles can be achieved by penitence and by returning to God and not by the extermination of witches. Concerning the punishment of witches, Melius was undoubtedly closer to Bullinger, who, as was mentioned earlier, did not see witches to be responsible for the troubles that had occurred. However, Brenz considered them to be punishable for their wickedness, that is to say, for their crime of conscience (Midelfort 1972, p. 37).

The thoughts expressed by Péter Melius were echoed in several authors of the 17th century in Debrecen. Right after his death, the pastors who determined the judgment of witchcraft in the city seem to have held a stricter opinion than he had. The first witch trials took place in Debrecen three years after the death of Melius, and the first death penalty was prescribed in 1575 .

From the 1570 s to the 1590 s, two preachers who were working in the city were assumed to have encouraged the initiation of witch-hunting. György Gönczi Fabricius (?-1595), who was an urban pastor from 1565, and who became the successor of Melius at the position of a bishop from 1577, had studied at foreign universities for eight years. Although I have not been able to trace his opinion on witchcraft, it may be suggestive that he studied in countries such as Switzerland, Germany, and northern Italy in the 1550s and 1560s, where he could have met witch hunters or embrace the idea of witch hunts (Szúcs 1871, vol. 2, pp. 542-43, 563-64). His views seem to have had no immediate effect on court practice after returning home, because during Melius's lifetime, he filled only the position of an associate pastor. The role of the other pastor, Tamás Félegyházi (c.1540-1580), however, can be discussed with more certainty. He was sent to Kolozsvár [Cluj-Napoca] in the 1560s by Melius in order to defend the Calvinist trend against the Anti-trinitarians. Félegyházi returned to Debrecen one year after the death of Melius and became a fellow pastor of Gönczi. I could not determine where he studied but in case he indeed had a role in witch-hunting in Debrecen, we may suspect the impact of Kolozsvár itself. During his stay in Kolozsvár, the magistrates had heard several witchcraft-related trials and even returned a verdict of a death sentence (Op. cit., p. 543, 564).

In 1579, Félegyházi published his treatise $A$ keresztyén igaz hitnek részeiröl való tanitás [Teachings on the sections of true Christian faith] for the first time. The passage on the sin of idolatry in this treatise condemned "superstition" [babonaság] and "all kinds of sorcery [varázslások]". Similar to Melius, his anger was directed at those who performed magical practices banned by the laws of the biblical Moses and also those who turned to the former. As he warned, "Don't turn to magicians, do not ask the fortune tellers, and avoid getting contaminated by them". Unlike Melius, Félegyházi has already emphasized that such people deserve the death penalty. He announced with Moses that "I will set my face against anyone who turns to mediums and spiritists to prostitute themselves by following them, and I will cut them off from their people." (III, 20:6); and "Let no one be found among you ... who practices divination or sorcery, interprets omens, engages in witchcraft, or casts spells, or who is a medium or spiritist or who consults the dead" (V, 18:10-11) (Félegyházi [1579] 1583, p. 306. I used the edition of 1583).

It is not a coincidence, therefore, that three of the earliest four defendants of the witch trials in Debrecen were experts of folk medicine, a positive magic condemned by Protestantism/Calvinism. One of them was also accused of poisoning (intoxicatio) and making a magical drink. 
The period between the 1620s and 1640s, which saw the first summit of witch-hunting in Debrecen and the highest proportion of witch burnings, can be characterized by the strict policy of the Reformed orthodoxy. The preachers of the era published numerous works on the regulations of moral life, and another series of sermons were dealing with the subjects of fornication, swearing, theft, suicide, etc. (Makkai 1984, pp. 531-35). The first mentions of the devil's pact and the witches' sabbath can also be found in this period in two collections of sermons published in the city.

Péter Margitai Láni (157?-1629) was a pastor in Debrecen between 1615 and 1618. Then he was elected as bishop in 1629. He pursued higher education in Wittenberg at the end of the 16th century. He was a schoolmate and a good friend of Alexis János Kecskeméti (1570?-1618?), who went to study in Heidelberg after Wittenberg. He published Kecskeméti's collection of sermons in Debrecen, whose opinion on witchcraft probably had a great impact on him (Op. cit., Szúcs 1871, vol. 2, p. 543; Kecskeméti Alexis [1621] 1974, pp. 16-24). Margitai also produced a collection of sermons that was published in 1617, in which, similarly to Félegyházi, he wrote about deviltry [ördöngösség] in connection with idolatry. This, in his view, is "a covenant with the Satan, which is executed through certain ceremonies in order to achieve certain things with his help". Margitai does not name the source where he could have read about these "ceremonies" and except the quotation above, he says no more about the topic. His interpretation of the covenant with the devil is peculiar. Apart from the devilish woman of the Bible, Margitai first brings up the names of two popes-Pope Sylvester II (c. 946-1003) and Pope Gregory VII (c.1015-1085)_as an example for being a devil's mate. Then he notes that "one can still find many of these people, both men and women creatures" [asszonyi állatok]. Following the tradition of Wittenberg and that of Melius's, he classifies them as experts of magical practices. Just as Hemmingsen at the end of the 16th century, Margitai also refers to the passage of Moses V, 18:11; and as Félegyházi, he argues that they deserve the death penalty. Paraphrasing Moses he proclaims, "be they men or women creatures, if the spirit of devilish fortune-telling is to be found in them, they should be killed ... you should stone them, they themselves make up the cause of their deaths" (Margitai Láni 1617, p. 78).

Margitai's friend, Alexis János Kecskeméti was a pastor first in Kecskemét, then in Nagybánya. His collection of sermons, published in 1621 in Debrecen, is a commentary on the Book of Daniel; the sections on dreams and magic deserve our attention.

Kecskeméti classified dreams into several groups. One of these categories is "diabolicum somnium", a devilish dream, under which he explained his views on the witches' sabbath. These views were most probably inspired by the Lutheran tradition that was based on canon law, as I discussed it above. The dream of those "bewitching-healing mates of the devil", as he emphasized, is imposed by the devil upon those who "come together, as they say, each year before the first day of the month of the Pentecost, and they go to a high mountain (they know where it is) on a broom; the sorcerers [bübájosok] from different countries used to gather together there. And as a testimony, they even say what they have seen there." All of this is, in Kecskeméti's opinion, merely an illusion, as "the devil plays with them. Not that they could really be corporeal, but the devil would make them believe that they went far away." He also considered as demonic delusion "when they see that some are being transformed into cats or wolves". He supported his argument with Luther's authority, quoting one of his cases of an "ointment using midwife". The woman-as the story tells us-wanted to prove to her priest that the witches were actually going out and gathering in a place. "For this reason, she applied an ointment on herself in front of the priest and many other people, and then raised her hands as if she wanted to fly. But suddenly she fell off and laid almost dead for a few hours on the ground. And when she got up after a long time, she said with great joy: herein you see that I was gone." Kecskeméti summarised with irony the moral of the story: "So plays the devil with them" (Kecskeméti Alexis [1621] 1974, pp. 144-45).

Kecskeméti did not explicitly say that the witches deceived accordingly would deserve death, but he judged more severely the activities of the experts of magical practices, just as several of his fellow preachers did. 
Kecskeméti distinguished two types of magic/conjuration. The first kind, which, as he says, "stays in his true power" is not to be condemned, but to be regarded as "very good", because it is merely a "study of things by nature". However, the other kind of sorcery, which is "based on a covenant with the devils", is forbidden. Moreover, its practitioners are worthy of the death penalty. Like Hemmingsen and Margitai, he also supported his argument with Moses V, 18:10-12. When he listed the various types of "demonic practices", such as fortune-telling from water, mirror, fire, palm, smoke, sieve [rosta], or nail, he condemned magical procedures that were also to be found in the popular/vernacular practices of his era (Op. cit., pp. 136-37). Further, he listed a few types of the experts of the condemned magical practices. Besides the biblical examples, just as Margitai, he mentioned six Roman popes as well. Of the "demonic men and women creatures" of his era, most of all, he raged against the fortune-tellers and the midwives, buthe also condemned the gypsies, who "used to tell prophecies from beans." Kecskeméti listed what forbidden fortune-telling [jóslás] might concern: when and where one would die, whether his/her spouse loves or not, whether (s)he would have a child or not, whether (s)he would have a son or a daughter. Fortune-telling was very strictly condemned by Kecskeméti; "no type of man is worse", as he said, than the fortune-teller, "because they are bound to something they are not sufficient for", that is, they are trying to compete with the divine providence.

Similarly, Kecskeméti rages against the practice of midwives, who performed healing activities, too, in the era. According to his opinion, midwives violate the divine providence, because they "want to become doctors of medicine, and try to cure with superstitious instruments, such as measurements [mérések], incantation [ráolvasások], or slips of paper [cédula] to be hung on the neck". Kecskeméti explained the topic in the form of a dialogue, as if a rural preacher, representing the official religious view, would educate a local peasant, who was considered to be simple and superstitious. For example, the latter asks a question: "Is it wrong when the conjuring midwives heal by measurements [mérések] [and] they do not say that it is a hagymáz [kind of a feverish illness] [that is, an epidemic sent by God]?" According to the preacher, it is undoubtedly wrong, because illnesses are imposed on people by God, and it also lies in His power to abolish them. The midwives and those who turn to them, therefore, express the weakness of their faith in God when they are trying to cure a disease with threads, strings, or [some form of] coal. The next question is: " ... if such a measurement remedy is against God, how come that it may sometimes help the patients? Further, some women creatures even say that if this good woman could not help me I would have died". The preacher argues: these medicines help because they were destined to heal, and this might happen because God is testing the strength of the faith of the people. Other "simple" questions ask whether certain elements used in church rituals can also be used for healing, such as quotations from the Bible written on a piece of paper and attached to the patient's neck, or incantations with the words of the Credo or the Lord's Prayer. According to the pastor, all this is, obviously, paganism and superstition, because these were not created to be means of healing. Prayer, for example, was "not created by Christ ... to make patches out of it, and tie [i.e., heal] diarrhea, gout, or hagymász". As a consequence, the act of those, who "go right to the whispering midwives who do magic when they, or their wives or children get sick ... is surely a great sin before God. My son or daughter was encharmed, if someone would recite an incantation above him/her, (s)he would recover". The preacher requires the "superstitious" villagers to follow the only legitimate way according to the dominant religious view for getting rid of illnesses: "Listen, appeal to God, call him for help, and believe him to be healed ... Because he says: invoke me, call me to help in the time of misery, I will liberate you". In the end, Kecskeméti declared that both the fortune-tellers and the healing midwives are "worthy of the worldly fire and the fire of Gehenna of hell as well" (Op. cit., pp. 148-55).

Again, it could not be a coincidence that there were six people (five healers and one midwife) among the nineteen defendants of the witch trials in the period between the 1620s and 1640s in Debrecen who were punished for their various medical practices. Three of them were sentenced to death. However, the devil's covenant or the attendance at the witches' sabbath did not appear in the text of the indictments or judgements of the era. 
Kecskeméti, as was mentioned previously, studied first in Wittenberg and then in Heidelberg at the end of the 16th century. The references in his collection of sermons include the names of Johann Brenz, Bullinger, and Luther, and even Caspar Peucer (1525-1602). The latter was Melanchton's disciple, son-in-law, and the head of the medical and mathematics department at the university of Wittenberg. In connection with the discussion on dreams, Kecskeméti referred to Peucer's treatise, the Commentarius de praecipuis divinationem generibus, which was published in 1555 in Wittenberg (Clark 1990, p. 55). Besides the Lutheran tradition in Wittenberg and the presupposed impact of canon law, the intellectual milieu of the university of Heidelberg might have also influenced Kecskeméti's concept of witchcraft. At the university of Heidelberg in the decades of 1570s and 1580s, two opposing opinions existed on the adjudication of witchcraft. Both opinions responded to the treatise written against witch hunt, De praestigiis Daemonum (1563) by the above-mentioned humanist and Lutheran doctor, Johann Weyer. According to Weyer, the ideas about the devil's pact and the witches' sabbath in the forced confessions of the tortured witches by no means have a real basis. Those are illusions created by the devil, or ideas due to a mental disorder, or "melancholy" of the accused. In Weyer's opinion, those accused of witchcraft are innocent and should not be punished. He, too, however, condemned the sorcerers and the experts of magic, and ordered them a punishment (Trevor-Roper 1969, pp. 73-75; Thomas 1987, p. 693; Baxter 1977, pp. 53-54). Among the opposers of Weyer's views at the university of Heidelberg, one can find Thomas Erastus (1524-1583), whose work, the Disputatio de Lamiis seu Strigibus (1572), deserves attention here. Erastus denied that the witches would merely be mentally ill, he was convinced that they indeed deny God and worship the devil. He thought that the witches actually fornicate with the devil and are able to harm their fellow human beings. Even if they are not capable of performing miracles by their own power, and this is all Erastus allows here, they deserve the death penalty because of their evil intentions (Midelfort 1972, p. 56).

Obviously, Kecskeméti did not share Erastus's opinion. His views were much closer to the thoughts of Hermann Witekind (1522-1603), a Heidelbergian mathematician, with which he defended Weyer's position. Witekind, just as Kecskeméti, was convinced that people tend to blame others for their bad luck, someone "on whom we can take revenge for all our trouble and loss, since God, who is the real cause of everything, is too high for us to reach and understand". As Witekind argued, the right path to avoid trouble is faith in God. He denied that the damage caused by the devil or the witches would be realistic and raised his voice against the punishment of those accused of witchcraft (Op. cit., p. 57).

As is apparent, Kecskeméti's system of thoughts reflects both the Wittenbergian Lutheran and the Heidelbergian Witekind's traditions as long as it considers witches to be innocent means of the devil but expects the practitioners of magic to be punished.

After the siege of Heidelberg in 1622, the Hungarian Calvinists started to attend British and Dutch universities. The study trips to England were of great importance for the town of Debrecen, because this is where the tendency of Puritanism, which consolidated in the 1660s, got inspiration from. Many of the Puritan preachers of Debrecen have expressed their views on witchcraft. One of them, Mátyás Nógrádi (1611?-1681), wrote a long treatise about "demonic practice".

Mátyás Nógrádi had studied in Leyden between 1644 and 1647, and also visited London. He was a preacher in Debrecen between 1649 and 1661. In 1661, he became the dean [esperes] of the Debrecen diocese, and in 1665 he took the position of the bishop of Tiszántúl Church District; he died in September 1681. His work, the Idvösség kapuja [Gate to salvation], published in 1672 in Kolozsvár, was translated from English; most probably his collection of sermons, entitled Lelki Probak" [Spiritual touchstone] and published in 1651 in Debrecen, was influenced by his experiences in the Netherlands and England. The appendix of this work is a short piece, a so-called Rövid Tracta [Brief treatise], which was intended to explain Az Ördögi practicáról mint kellyen ítélni e világon a keresztyén embernek [How a Christian should judge the devil's practice in this world] (Herepei 1966, vol. 2, pp. 183-86; Nógrádi 1651). 
The ideas found in the Rövid Tracta themselves can be divided into two groups, in which the author determines whether the power of the devil is limitless or not. First of all, pastor Nógrádi admits that "Deus est author naturae", so that He is the only one with supernatural power. He, however, allows the devil to send rain, wind, and lightning, but, as Nógrádi warns the readers, neither Satan, nor the witches, the "ugly bugs", are able "to do true wonders, but only do admirable things". Consequently, sorcerers are able to harm people but only as long as God allows them; they can only harm people's bodies and the "external stuff", but not their souls (the biblical Job is an example). These damages are the trials of God, and indeed serve people. Nógrádi argues that God allows people to get hurt only to "weed out his sons and lovers, or to verify faith and peaceful acceptance". He does this in order to punish the sinners and, on the other hand, to determine (at this point, the preacher turns to his readers) "whether you love the Lord, your God with all your heart and with all your soul" (Nógrádi 1651, pp. 183-86, 164-65).

Nógrádi, just like the other pastors discussed earlier, ascribes to the divine providence an absolute power in this world; further, he stress that Satan "non realiter sed apparenter" can do supernatural things. These are not miracles, but just "amazing delusions" (Op. cit., p. 186).

Nevertheless, it seems that when describing the sins of sorcerers and witches, Nógrádi followed a much stricter doctrine than his predecessors. In his system of thoughts, in some cases, the principles of supreme good and supreme bad were given equal weight. For example, he says, that "sorcery means the abandonment of God, the Summum Bonum, and embracing the devil, the Summum Malum. This way God is condemned and the devil is worshiped". He argues elsewhere: "The sorcerer is an embodied Devil, just as the Antichrist, who, with the help of Satan's enormous power does all kinds of miracles and great signs on this earth". Nógrádi emphasizes that "no other sin offends God as much as sorcery does", because this "nasty obnoxious activity" defaces the name and memory of God, Christ's Cross, and the Holy Spirit (Op. cit., pp. 161-62).

Compared to the opinions presented here so far, the main novelty in Nógrádi's argument is that he not only describes in detail the different types of the devil's pact, but, as it seems, he thinks such pacts might actually be feasible. Considering Satan's field of operation, as much as it is submitted to God, it is regarded as most excessive compared to all other preachers' opinions discussed here previously. According to Nógrádi, "a full pact with the devil" is "when a person violates and breaks his faith in God, and further, dedicates his body, soul, and life to Satan through an alliance of a certain mark. This is a clear indication of witchcraft" [boszorkányság]. Witches [boszorkányok] embrace an upside down world (See Clark 1980), an idea that appears at Nógrádi for the first time in Debrecen: "we [witches] made a bond with death, we got peace through fire, lie is the strong shield of ours, we take pride in delusion, our prophecy is a sweet endearment". And they do all this, as Nógrádi condemns them, because Satan "promises a reward to his speedy scudding locust-tailed soldiers" (Nógrádi 1651, p. 174).

According to the preacher, "the covenant with the devil" or "pactum" can be "expressum", that is, evident, and can be "implicitum", that is secretive or "clandestine". In the first case, when one offers himself to Satan, the covenant can be made verbally or in writing (with blood), or it can be achieved through a mutual agreement, when both of the parties offer their services to one another. Nógrádi does not explain this further in detail, nor does he mention any characters he thinks about.

As for the "clandestine" type of the covenant, Nógrádi lists five different cases under that category, including the experts of magical practices and those who turn to them. They have also been condemned by the previously mentioned Calvinist authors; Nógrádi seems to systematize them. Firstly, he considers the fortune-tellers to be allies of the devil, these tell the future by "tin casting", "turning of the sieve", "the sound of the birds"; then the "healers, who apply ointments" to cure. These sorcerers violate the scope of the divine providence.

Certain parts of the Rövid Tracta allow us to construct two rather different stereotypes about witches in Nógrádi's system of thoughts. The first we might call an "ecclesiastic" or "official" model: it comes from those statements in which Nógrádi describes what makes man a sorcerer or a witch, and what are the "convincing" and "certain" signs of witchcraft. The second, the so called popular/"vernacular" 
model, is composed of those characteristics that do not make someone a witch from the point of view of the Reformed church; that is, the probable but not certain ("probabilia sed non certa") signs of witchcraft.

Let us first see the "official" stereotype about witches. A witch is a person who "fully abandons the Lord and subjugates her or himself to the violence of the devil" and overtly makes a covenant with him. Humans with certain "particular sins" are predisposed to approach the devil. The examples include "idolatry, false worship, perjury, blasphemy, cursing, swearing, dirty desires [fornication], curiosity, hate, envy, the desire of vengeance ... avarice". According to Nógrádi, poverty can also be a reason for turning away from God. It is interesting to see that Johann Weyer's opinion that witches are innocent melancholics is turned upside down by Nógrádi: he thinks that melancholia attaches a person to the devil.

Additionally, a witch is she who speaks before the court incoherently, "is a volatile vagabond giving incongruous responses", and who admits his or her sin. A witch is she whose "superstitions and delusive actions" were proved by many living testimonies, and who is bespoken by other "sorcerers". A witch is she who, instead of attending daily services, "visits the houses of disreputable sorcerers" during the night. Finally, a witch is she who "encourages others to deal with witchcraft" (Op. cit., pp. 163-69, 174, 182-83).

The other popular/"vernacular" stereotype that can be derived from Nógrádi's system of thoughts is the following. Old people (those of "decrepita aetas") who are surrounded by bad news or "rumurs" are also considered to be witches. When hearing such "old news", people tend to be suspicious, especially if the incriminate person belongs to a "similarly suspected family", or has "impossible [képtelen] bodily marks originated from the devil" (Nógrádi has probably listed this feature at a wrong place), if (s)he is cursing or swearing often, threatening others, and if upon his/her touch a corpse starts to bleed. Finally, according to this model, too, a witch is characterized by a "poor and humble fate" (Op. cit., pp. 162-63, 180-82).

The purpose of Mátyás Nógrádi's Rövid Tracta was to help the secular magistrates to judge witchcraft-related cases, because, as the preacher wrote, "it is so difficult ... that often the divine lawmakers' mind ... get confused." Undoubtedly, the ultimate suggestion of his work is that the magistrates should act with great caution when encountering such cases. Nógrádi suggested that the popular/"vernacular" model of witchcraft should not be regarded immediately as an evidence, and that even the elements of the other model, legitimized by the church, "should be carefully inspected not to make mistakes after hearing the testimonies". His warning was directed to his congregation, too, "especially to the bad disobedient youth", in order not to make "false testimonies" about their fellow humans.

Nevertheless, when Nógrádi discussed the punishment of witches, he judged them far more strictly than the previously discussed preachers. He condemned them not only to physical but spiritual death, and even to eternal perdition, and regarded them worthy to "suffer perpetually in a sulphurous burning lake", making no distinction, unlike his predecessors, between those innocents deceived by the devil and those who were guilty of practicing magic. When reasoning for a strict punishment, he came up with a new argument not stated before. The witches and the sorcerers "by the covenant with the devil become enemies of the Ecclesia, and by this the civil society, the respublica would [also] get confused". It is very dangerous to endure this, he says, because God imposed his punishment on the Jews exactly for sorcery (Nógrádi 1651, pp. 190-92). The opinion that God's punishment can be abolished by penitence was previously asserted in Debrecen, but at Nógrádi it seems less emphasized; whilst the approach, according to which witchcraft may be a cause of God's wrath and only its complete destruction can help avoid the plague of God, is new in the city.

The popular/“vernacular” stereotype extracted from Nógrádi's system of thoughts was probably based on the everyday experiences of the pastor and reflected the basic perception of witches in the contemporary congregation at Debrecen. The other model, due to the lack of local traditions, as I mentioned above, might have conceived during his travels in England. This was assumed by the 
historian László Makkai, too (Makkai 1981, p. 117). Nógrádi visited England in 1645, when the biggest witch hunt in the country's history took place; it was led by Matthew Hopkins (?-1647) in Essex. According to the research of Alan Macfarlane, this was the time when, in the persecution of witches, the concept of diabolical witchcraft gained the greatest importance (Macfarlane 1970, p. 189). During his stay, Nógrádi could have been influenced either by pamphlets or reports of burnings, or by the English Protestant literature of demonology. László Makkai has suggested earlier that Nógrádi could have known the Discourse of the Damned Art of Witchcraft, a book of the Puritan theologian, William Perkins (1558-1602), published in Cambridge in 1608 (Makkai 1981, p. 117). It appears that Makkai, although he did not compare the two works, was on the right track. Nógrádi did not refer to the English author by name. However, there are several common points in their treatises on demonology.

When Stuart Clark interpreted the concept of the witches' sabbath as an inversion of the social and moral order, he referred to the writings of William Perkins. Perkins made a commentary on Samuel I, 15:23, which says "For rebellion is like the sin of divination, and arrogance like the evil of idolatry". He called witches "the worst possible traitors and rebels", who renounce God, the King of Kings, leave the company of the Church and people, become enemies of the state, and enter into an alliance with their supreme enemy, the Devil (Clark 1977, p. 176). This argument, as we have seen, first appears in Debrecen in Nógrádi's writings; the very strict punishment of witchcraft which he stands for is based on the betrayal of both the "Ecclesia" and the "Respublica".

Further, Perkins did not doubt the alliance of witches and the devil and this possibility was maintained by Nógrádi as well. The opinion of the English and the Hungarian preacher in the question of condemning benevolent magic also corresponds to each other, even though, as we have seen, by the age of Nógrádi, this approach had a significant local tradition in Debrecen. When Nógrádi says that no one is defacing the name of God, Christ's Cross, and the Holy Spirit more than the fortune-teller and "ointment user" sorcerers, he seems to be echoing Perkins's idea that the experts of positive magic, the "good witches", are even more threatening than the "black witches", because the former are not rejected by their community, so their successful practices weaken belief in the divine providence in the souls of their patients. The "good witches", as Perkins describes, are "the most disgusting and hateful monsters" (Thomas 1987, pp. 300-6).

In the 1660s and 1670s, Mátyás Nógrádi, first as a dean, and then a bishop, was one of the most prominent figures of Debrecen-based Puritanism. Before we analyze how the local witch hunt occurred under his office and influence, we need to consider other Puritan preachers who also expressed their opinion during this period in the city.

Five years after the publication of Nógrádi's work (1651), the issue of witchcraft was rediscovered in Debrecen. This time at two school exams, held under the presidency of the Puritan preacher György Komáromi Csipkés (1628-1678). The texts of these exams were later published in Latin in Nagyvárad [Oradea] (Mediomontanus Cimbalmos 1656; Csehi P. 1656). The exams were open to the public, and several prominent persons attended. Apart from Mátyás Nógrádi, Mihály Vigkedvú, the chief judge of Debrecen was there, and also several town senators and local pastors turned up, including pastors from Diószeg, Bihar county, the chief judge of Sárospatak, Zemplén county and his senators, the captain of Székelyhid, Bihar county, and other members of the council from different places.

The topics of the exams of the two respondents, András Csehi P. and János Mediomontanus C., were based on some ordinary questions of Calvinist demonology: the power of the devil and the witches, their limitations, the perception of benevolent magic, and the punishment of witchcraft. As is clear from their references, the respondents were deeply aware of the two traditions of the interpretation of witchcraft defined by Eric Midelfort and discussed above, that is, a tradition based on the Malleus maleficarum and another one based on the canon law. As it seems, they voted for the latter. However, just like Nógrádi, they did not completely rule out the possibility of the devil's pact.

Concerning the first topic, András Csehi P. explained that the devil has no power "beyond the air" ("supra aerem"); he is unable to move the stars or other celestial bodies, for example, to remove the moon from the sky, or cannot steal the light of the stars. And, "underneath the air" ("infra aerem") he 
can only act with the permission of God, who, according to the widely used argument, allows him to operate in order to test the faithfulness of men and to ascertain the strength or weakness of their faith (Csehi P. 1656, chp. A2).

Of all the ideas on witchcraft found in the Malleus maleficarum, the two Puritan disciples only accepted that the witches gain their damaging power from the devil. András Csehi P., referring to Johann Weyer, denies that witches would be able to create lightning, winds, move clouds, destroy the crops, bewitch the human body by acquiring excrement, urine, blood, hair or nails, or move it from one place to another in a very short time. Based on Weyer's arguments and the "Jus Canonicum", they both claim that the demonic practices detailed in the Malleus maleficarum are not real but are merely illusions created by the Satan and only the sick souls, the melancholic and the fool believe them to be true. As Mediomontanus listed, "phantasticae et imaginariae sunt" that the witches take little babies, cook them and make grease for flight from their fat, unnoticeably invade houses through chimneys, windows, or small holes and disturb the inhabitants, travel several miles in four or five hours, and if they wish, they can be transformed into animals (cats, pigs, donkeys) or soulless things (plants, straw, cartwheel) (Mediomontanus Cimbalmos 1656, chp. B2). Mediomontanus considers another popular belief to be impossible and illusory - that during the night the flock of witches fly to the Gellért hill in Buda (the capital of Hungary, under Turkish occupation in the period) to dance and have a debauch. ${ }^{4}$

Concerning the question of the devil's pact, Mediomontanus compares Johann Weyer's and William Perkins's opinions and although he agrees with the former, he does not entirely exclude the possibility of such pacts. Weyer, as was said earlier, denied the possibility of an alliance between a witch and the devil based on the fact that the former is a material-corporal ("corporalis") but the latter is a spiritual ("spiritualis") entity. This antagonism precludes any relationship between those two in his opinion. Referring to Perkins, Mediomontanus disproves Weyer's statement with the power of the Bible saying that according to Scripture, an alliance could exist between God (an entirely spiritual entity) and flesh-and-blood humans, as testified by the cases of Adam, Noah, Abraham, Isaac, or Jacob. For such covenant, he argues, a union of thoughts and will is sufficient, physical presence ("circumstantialer") is not needed from any of the parties. In Mediomontanus's opinion, the pact with the devil is thus feasible. However, it is eventually the devil's delusion ("fraus et impostura") that can only be believed by the credulous or the mentally perplexed. Mediomontanus, as opposed to Weyer, does not conclude, however, that the innocent, deceived witches do not deserve punishment. He thinks that witches deserve death by burning because of their intention, which is obviously evil if they were looking for an alliance with the devil (Mediomontanus Cimbalmos 1656, chp. A3, B).

According to the two respondents, harmful witches are not the only ones who enter into an alliance with the devil. The "lamia bona" or the "praestigiatrix juvans", that is, the "good witch", makes a covenant with the devil in order to do good, to heal bewitchment or make predictions. As can be read in András Csehi P., "inquiring about the patients by lead casting, belt measurement [övmérés], sieve rotation, or by the methods of old women ... just as ... whispering, incantation, healing are not only useless but superstitious and idolatrous" (" ... non tantum inutiles sed et superstitiosae ac idololatriae sunt") (Csehi P. 1656, chp. B2).

The effect of Mátyás Nógrádi's treatise can be seen in that the above mentioned "ecclesiastic" vs. popular/"vernacular" stereotypes of witches are repeated almost word by word by András Csehi P. In Csehi P., the former also consists of "convincing" signs" ("signa convincentia") while the latter of "false" or "conjectural" signs ("signa falsa, probabilia, conjecturalia"). According to him, those defendants can be punished who admittedly enter into an alliance ("foedus") with the devil or cause detriment to his fellow humans in a supernatural manner, and all this is proven by authentic witnesses. Referring to Moses II, 22:18, he regards these persons even worthy of death (Op. cit., A3, B).

4 For a Hungarian translation of this part of the argument of Mediomontanus, see (Klaniczay 1986, p. 283, note 117). 
The idea of the covenant with the Satan cannot be found in any other works of the Puritan preachers in Debrecen. For example, Gellért Kabai Bodor (1640?-1681), who was a pastor in Debrecen between 1674 and 1681, mentioned in his collection of sermons entitled Hegyes ösztön a Sátánnak angyala [Disturbing Instinct is the Devil's Angel, 1678] that "sorcerers and charmers", "seers", and "men and women creatures whispering prayers learnt from the devil" are both companions and means of Satan, but he never spoke explicitly about such an alliance (Kabai Bodor 1678, pp. 23, 36).

By the middle of the 17th century, the pastors in Debrecen seem to have clarified for good the interpretation of the concept of the devil's pact. As we have seen, they considered it to be feasible to some extent. However, it was regarded to be a demonic illusion, a delusion of Satan. Neither the disciples of Mátyás Nógrádi nor that of György Komáromi Csipkés forced the originally Catholic notion of demonic witchcraft with the devil's pact onto the popular (or seemingly popular) notion of witchcraft, which was otherwise not necessarily trusted. Especially not because it was extraneous to both their religion and demonology (On the differences between Catholic and Protestant demonology see Clark 1990).

Lutheran preachers from southwestern Germany led by Johann Brenz formulated their main ideas about the omnipotence of the divine providence and the limited power of Satan and the witches in relation to the explanation of the causes of hail and storms. Calvinist preachers in Debrecen did this in connection with the diseases and their healing, as we have seen at Péter Melius or Péter Margitai Láni. It is worthy of note that plague epidemics were included in those diseases, especially in the era of the Puritanism in Debrecen.

Several preachers have expressed their opinions about the plague before the Puritans in the city, just like Péter Melius. However, it seems that until the second half of the 17th century, these works dealt with only two fundamental issues. The first, obviously, was the plague itself: it was regarded as God's punishment to sinful men. Many, including Péter Melius, thought that it is not possible to avoid it without penitential practices and returning to God. The second question concerned what "external devices", such as drugs, can be used and in what extent apart from "internal or spiritual healing". There was no agreement in this question among the preachers of the era (Kristóf 1991). There was one particular question, though, in which all preachers agreed, that the so called "superstitious" medications are not only unhelpful but their use falls under a strict ban. The reason for this is similar to that of the condemnation of positive magic, that is, the use of "medication that is not ordered by God" questions the belief in divine providence.

In 1579, Tamás Félegyházi wrote: "the medicines of magicians and sorcerers are forbidden in the Writings [of God], those who want to heal the sick with whispering words, casting and lifting the spell, or any other kinds of superstitions". Such superstition was, for example, that "the first on whom the plague started off, should be digged out from the ground and pulled under the gallows-tree". Further, "a Christian man should not expect a cure from these associates of the devil, but instead, he should hold on to the Word of God, and apply only the remedies ordered by Him" (Félegyházi [1579] 1583, pp. 461, 463-64). Alexis János Kecskeméti wrote the above-mentioned sermon in 1621 during a plague epidemic. It is no coincidence, therefore, that when he condemned the activities of the healing midwives, he was referring to the example of "hagymáz", a feverish illness: the word was also used for the plague in the era. As he wrote, sickness is given by God to sinful men. Thus, it was regarded extremely wrong that midwives are so courageous that through "measuring and incantation" cross the paths of God's unfathomable providence (Kecskeméti Alexis [1621] 1974, pp. 148-49, 348).

Concerning the origin of the plague, the early preachers of Debrecen seem to have argued with only two positions. One was the astrologers' opinion, who deduced the epidemics from some "negative constellation" of the planets, while the other opinion regarded it as "blind luck". Only the Puritans, and among them firstly pastor István Diószegi Kis (c.1635-1698) from Diószeg, who knew the folk culture of his era so well, explored that there exists a third, very widespread alternative explanation of the plague. The one found in the popular belief of witchcraft. 
In 1679, when Diószegi was preaching about "a variety of diseases", a serious plague epidemic raged over the country. These sermons, as earlier in Kecskeméti, were published in a dialogue form. Reading Diószegi's text feels as if a member of the congregation would ask questions about his own ideas from the learned preacher. From these questions, the third alternative interpretation can be constructed about the origin of the plague in late 17th-century folklore. For example, "Can one find out whether this illness is coming from the devil or from a witch?" Or, "If you could find out that this illness is coming from the devil, would it be allowed to cure it with the help of the devil or witches?" (Diószegi Kis 1679, pp. 159-60).

In his answers, Diószegi does not exclude this kind of explanation. However, as he says, the illness-bringing power of both the devil and the witches comes from God, who may use them as a means of expressing his anger. "The great power the devil has on this earth ... with the permission of God he can make people cripple, blind, take away their health and even kill them, as seen in the story of Job and his sons" (Op. cit., p. 159). Therefore, "there is no need to struggle" to determine where the illness is coming from, because the ultimate reason is always the Almighty God. "There is no evil in the city that Jehovah would not beget", and the devil "is not able to curl a hair unless God wants this". Turning to a healing "witch" is useless, because he or she can not heal an illness which was sent by God as a punishment; and when (s)he tries, (s)he serves the devil and falls into idolatry. "If [the healer] was a good doctor and knew all the types of trees and herbs ... this would [be idolatry] as (s)he would turn away from God and would turn to the devil" (Op. cit., p. 160).

That same year on St. George's Day, when, according to the popular belief, witches are particularly active, Diószegi gave his sermon. This sermon is well known in the ethnographic scholarly literature, but it has been used only as a historical source of folk magic for the end of the 17th century (Dömötör 1981, p. 112). I want to draw attention to the fact that when Diószegi enumerated the great many methods of folk magic, his interest was not necessarily led by an interest in folklore. All the witches, "who mess up men with a spell, with the help of God, feed them or kill them", and experts of positive magic "who enchant the hens to increase egg laying and the cows to improve the quality of their milk", who contact the dead, "the fortune tellers", and all those who turn to them, are in alliance with the devil, the preacher argues, and deserve to be burnt or stoned. Diószegi also blames the courts "who do not take care about these [cases]" (Diószegi Kis 1679, pp. 196-98).

István Diószegi Kis played an important role in disseminating the decisions of the 1681 Council of Margita. The Calvinist Council was assembled under the chairmanship of bishop Mátyás Nógrádi, and, among others, decided that "sorcerers, and those who contact them, must be expelled from the Temple". On the request of the supreme church authorities, the topics discussed in the Council were spread by Diószegi verbally in sermons in his ecclesia, and also in print form published in Debrecen (TtREL, I.31.a, vol. 2, p. 526; Diószegi Kis 1682, chp. A2). The text of his "Varázslókrul való prédikáció" [Sermon about sorcerers] was Moses II, 22:18: "Do not allow a sorceress to live." Conjuration, as he explained, is a "repelling, obnoxious craftsmanship, in which, through the devil's work, a sorcerer does an apparently extraordinary thing with the permission of God". The decisions of the Council were obviously formulated under the influence of Mátyás Nógrádi; they maintained the traditional ecclesiastical opinion that the devil and the witches could only harm people with the permission of God, and their activity is not realistic, only "astonishing". However, they also represented Nógrádi's views that were strictly condemning sorcery and witchcraft. They concluded, as phrased by Diószegi, that "Sorcery is a deadly $\sin . .$. because God says, do not allow a sorcerer to live ... because (s)he contaminates the wakeful to death ... because a sorcerer is a spiritual fornicator [lelki parázna] ... because (s)he copulates with the devil ... because (s)he is excluded from the land of God". The sorcerer should be punished with "beating to death with stones, burning with fire, as a spiritual fornicator, and an associate of the devil" (Diószegi Kis 1682, chp. B, B2).

To sum up, I would say that the views of the Puritans in Debrecen were not alleviated, but rather deepened the specific duality that can be observed in the preaching tradition about witchcraft before the era of the Puritans. The opinion that the divine providence has absolute power over the things 
of the world was maintained, just as the view that the devil and the witches can only act with the permission of God, and that all their actions are illusory. On the other hand, the Puritans accepted the view that the experts of traditional magical practices in folk culture, such as healers, midwives, fortune tellers, etc., commit crimes, because they turn away from the almighty, divine providence which is (and should remain) beyond human perception. In this sense, the Debrecen Puritans diabolized these practices, and considered their practitioners worthy of the death penalty.

As the case of Nógrádi and the disciples of Komáromi Csipkés have shown, the possibility of an alliance between the devil and the witches itself first emerged in the views of the Puritan thinkers. Even if they basically considered it to be phantasmagoria, they believed that it should be punished with the death penalty because of the evil intentions of the witches and their purpose of an alliance. With considering the alliance with the devil as a criterion of "punibilitas", and so as a possibility, they indeed accepted the idea of the pact.

It is not a coincidence again that from the 1680s onwards, such phrases as the "devil's mate", "cum daemonibus colludens", "diabolica cooperatio", and even "contractus cum daemone" appear in the accusations in Debrecen and Bihar county witchcraft trials. Therefore, László Makkai's assumption, according to which the number of witch trials between 1650 and 1680 decreased in Debrecen and the judgements were less strict by the influence of the Puritans (Makkai 1981, pp. 127-28), can be questioned based on several points. The mid-17th century, and especially the second half of it was a particularly difficult period with many local fights and wars. It can be rightly assumed that the reduced number of witch trials in Debrecen and Bihar county is due to the constant insecurity of life rather than the influence of Puritanist ideas. Four witch trials are known from this period, one of them was concluded with a death sentence; further, several defamation cases were documented. After the Council of Margita in January 1681, chaired by Mátyás Nógrádi, and perhaps due to the provisions taken against sorcerers, at least seven defendants were sentenced to death in Debrecen during the period between May to July. All of them, except one, earned the death penalty. Four of them were burned at the stake, one was stoned, and one was a victim of an unknown death penalty. Bishop Nógrádi died in September that year. As was mentioned earlier, between 1681 and 1740 the ratio of death penalties were $36.58 \%$ in the town. Although this was lower than the national average, but, concerning the town of Debrecen, it indicates a second wave of witch-hunting. Considering the period, between 1703 and around 1727, when the puritan preacher, György Komáromi Csipkés, and his similarly educated son of the same name served as counts of Bihar county, the sedria [county court] issued at least twenty death sentences. Based on these facts, I think, one should not look for attempts to reduce persecution in Puritanist thought about witchcraft, especially as the practice of benevolent magic was not considered less severely by the Puritan preachers than the negative one. For example, between 1677 and 1700, ten healers, a midwife and a "seer" were found among the twenty-five accused in Debrecen.

According to my knowledge, the last treatise in Debrecen, which discussed witchcraft and sorcery in detail, was published in 1719. It was the work of Imre Pápai Páriz (1649-1716), was entitled Keskeny út [Narrow Path], and was first published in Utrecht in 1647. It had several later print editions in Hungary (Pápai Páriz 1647; see also (Trócsányi 1936)). Pápai basically repeated the local pastor's ordinary points in Calvinist demonology that were discussed earlier. As he writes, the devil and the witches can only do harm to people with the permission of God. They are, as Pápai says, "tied [to the Devil] with an alliance", he, however, did not consider this point important enough to describe in detail. Pápai seems to have followed the local preachers' tradition in condemning the practitioners of positive magic, too. According to him, the fortune-tellers and the seers are in connection with the devil. "They support each other and serve each other, the devil ... is a quick and fast soul like lightning, travels far lands abruptly, finds the lost cattle, whispers into the ear of the seers as if (s)he is his mate thus the seer can often tell the truth". And finally, Pápai is warning the reader: "never live in a forbidden world, not even for a great benefit. Do not appeal to the devil or his mates, because you are going to pay with suffer in the future" (Cited in (Trócsányi 1936, pp. 283-85)). 
In the end of our survey of the early modern Protestant/Calvinist concepts of witchcraft in the city of Debrecen and the surrounding Bihar county, the following conclusions can be drawn. The Reformed Church in Hungary has indeed developed a discourse of demonology, but, due to the specific views of Protestantism, the devil played a rather limited role in it. This discourse narrowed down Satan's field of activity, questioned the possibility of his physical appearance, and generally regarded his activity and "miracles" to be a phantasmagoria. Therefore, it could not provide a proper "ground", neither for the idea of the devil's pact, nor for the vision of an orgiastic witches' sabbath. Even if these ideas were addressed in sermons or were mentioned in connection with the criminal code, Praxis Criminalis (Kristóf 1998, pp. 41-42), they never seem to have formed a coherent and detailed diabolic "mythology" of witchcraft as can be traced, for example in the Basque country, in French or certain German territories, where those ideas were inspired by Catholicism and were part of the demonological literature originating from the tradition of the Malleus maleficarum (Henningsen 1988; Midelfort 1972, pp. 58-64; Muchembled 1978, pp. 289-340; Muchembled 1981). Thus, we may presuppose, just as Eric Midelfort, and more recently William Monter and Stuart Clark assumed, that this specific, limited demonology, which diabolized the practices of benevolent magic and was prevalent in Protestant-and especially Calvinist—countries and was also present in the Calvinist aeras of Hungary, was the reason that in these lands the witch persecution remained moderate in the early modern period, whilst it was largely directed against the experts of benevolent magic (Midelfort 1972, pp. 70-71; Clark 1990, pp. 45-81; Monter 1976, pp. 42-44; See also Horsley 1979).

[... ] The belief of witchcraft was still a rather widespread phenomenon in the 18th century. In the investigated area, the city of Debrecen and the surrounding villages of Bihar county, both the accused witches and their alleged victims can be found among peasants, craftsmen, citizens and farmers, beggars and judges. I have found a pastor victim, and a "witch" who was the wife of a county judge.

[ ... ] The Protestant/Calvinist church throughout the entire period of the witch persecution has strictly condemned and convicted the practitioners of positive magic, thus clearly placing their activities within the framework of witchcraft. It is remarkable that in the investigated area, between 1575 and 1766, no less than 74 of the 303 accused witches were persons with some kind of knowledge in everyday magic/sorcery. At this point, it seems that the idea of witchcraft corresponded in the "official"/ecclesiastic discourse and in folk culture. In Debrecen, between 1575 and 1759, there were 127 persons accused of witchcraft, of which 54 can be regarded as some sort of expert in positive magic. This includes 39 healers and six midwives, and another six defendants were linked to táltos [some kind of shamanistic] beliefs. The rest was described by the witnesses as "seers" [nézók], fortune tellers or "wise women/men". In Debrecen, healers/"wise women" were present among the defendants from the very beginning. The first "seer" and the first midwife were accused in the decades between 1610s and 1630s.

There were only 20 persons accused of positive magic from the villages of Bihar county between 1591 and 1766: among them were six healers, seven midwives, and one táltos; the remaining also had some kind of magical skills (seer, fortune teller or wise women/men). The proportion of magical experts as accused witches seems much smaller here than in Debrecen and this is certainly due to some local social factors. ${ }^{5}$ It is not easy to decide whether the sedria [county court] in Bihar county judged less strictly or more rigorously than in Debrecen in cases of the experts of positive magic. Not all the judgments have been left to us. I know, however, of two death penalties given to such kinds of healers (a woman in the village of Püspöki, 1721, and another one in Nagykereki, 1723).

In the city of Debrecen, the magistrates seem to have followed the path designated by the Calvinist Church: from the 54 accused, no less than ten healers and two midwives were sentenced to death. Thus, approximately $22 \%$ of the representatives of positive magic received the death penalty. At the same time, comparing the number of all the 104 judgements known to us to the number of those sentenced to

5 These are discussed in Chapter 5 of my book, see (Sz. Kristóf 2017) and also (Sz. Kristóf 2013). 
burning at the stake (32\%), one may conclude that the secular court judged the activities of those experts of benevolent magic less strictly.

Given the fact, however, that only a small number of cases are left to us, that there are no comparable data available from other courts so far, and further, as we have seen above, that the charge of positive magic functioned as an aggravating factor along the guidelines of Calvinist demonology, more elaborate conclusions should wait to be drawn.

Funding: This research received no external funding.

Conflicts of Interest: The author declares no conflict of interest.

\section{References}

Baxter, Christopher. 1977. Johann Weyer's De Praestigiis Daemonum: Unsystematic psychopathology. In The Damned Art. Essays in the Literature of Witchcraft. Edited by Sydney Anglo. London: Routledge \& Kegan Paul, pp. 53-75.

Bornemisza. 1980. Heltai Gáspár és Bornemisza Péter müvei [The oeuvre of Gáspár Heltai and Péter Bornemisza]. Edited by István Nemeskürty. Budapest: Szépirodalmi. First published 1579.

Bucsay, Mihály. 1985. A protestantizmus története Magyarországon 1521-1945 [The history of Protestantism in Hungary]. Budapest: Gondolat.

Clark, Stuart. 1977. King James's Daemonologie: Witchcraft and Kingship. In The Damned Art of Witchcraft. Edited by Sydney Anglo. London: Routledge \& Kegan Paul, pp. 156-81.

Clark, Stuart. 1980. Inversion, Misrule and the Meaning of Witchcraft. Past \& Present 87: 98-128.

Clark, Stuart. 1990. Protestant Demonology: Sin, Superstition, and Society (c.1520-c.1630). In Early Modern European Witchcraft. Centres and Peripheries. Edited by Bengt Ankarloo and Gustaf Henningsen. Oxford: Clarendon Press, pp. 45-81.

Clark, Stuart. 1997. Thinking with Demons. The Idea of Witchcraft in Early Modern Europe.. Oxford: Clarendon Press.

Cohn, Norman. 1994. Európa démonai. A boszorkányüldözés története. (Hungarian translation of Europe's Inner Demons. An Inquiry Inspired by the Great Witch-Hunt). Budapest: Corvina.

Csehi P., András. 1656. Disputatio theologica de lamiis veneficis ... sub praesidio ... D. Georgii C. Comarini ... publico examini subjicit Andreas P. Csehi. Varadini: n.p.

Diószegi Kis, István. 1679. Kiosztatott Talentum [Talent distributed]. Debrecen: n.p.

Diószegi Kis, István. 1682. A' Sz: Generalis Gyülesben lett Némelly Deliberatumok [Deliberations Made at the Sacred General Synod]. Debrecen: n.p.

Dömötör, Tekla. 1981. A magyar nép hiedelemvilága [Hungarian Folk Beliefs]. Budapest: Corvina.

Félegyházi, Tamás. 1583. Az keresztyéni igaz hitnek reszeiról valo tanitas [Teaching about the Parts of True Christian Faith]. Debrecen: n.p., First edition: 1579.

Henningsen, Gustaf. 1988. A boszorkányok ügyvédje. A baszk boszorkányság és a spanyol inkvizíció (1609-1614). (Hungarian translation of The Witches' Advocate: Basque Witchcraft and the Spanish Inquisition (1609-1614)). Budapest: Kossuth.

Herepei, János. 1966. Néhány adat Nógrádi K. Mátyás életéhez [Data to the life of Mátyás K. Nógrádi]. In Adattár a XVII. század szellemi mozgalmainak történetéhez II. Edited by Bálint Keserú. Budapest-Szeged: JATEPress, pp. 183-86.

Horsley, Richard A. 1979. Who were the witches? The social roles of the accused in the European witch trials. Journal of Interdisciplinary History IX: 689-716.

Kabai Bodor, Gellért. 1678. Hegyes Ösztön a' Sátánnak Angyala [Disturbing Instinct is the Devil's Angel]. Debrecen: n.p.

Kecskeméti Alexis, János. 1974. Prédikációs könyve. Dániel próféta könyvének magyarázata [Book of Sermons. An Explication of the Book of Prophet Daniel]. Edited by Lajos Szuromi. Budapest: Akadémiai kiadó. First published 1621.

Kiss, Ádám. 1882. A XVI. században tartott magyar református zsinatok végzései [Deliberations of Calvinist synods held in Hungary in the 16th century]. Budapest: Franklin Társulat.

Klaniczay, Gábor. 1986. Boszorkányhit, boszorkányvád, boszorkányüldözés a XVI-XVIII. században [Witchcraft belief, witchcraft charges, witch-hunting in the 16-18th centuries]. Ethnographia XCVII: 257-95. 
Kristóf, Ildikó. 1991/1992. "Wise Women", Sinners, and the Poor: the Social Background of Witch-Hunting in a 16/18th-Century Calvinist City of Eastern Hungary. Acta Ethnographica Hungarica 37: 93-119.

Kristóf, Ildikó. 1991. "Plague of the Plagues": Epidemic and Riot in Debrecen in 1739/42. Ethnos I: 64-77.

Kristóf, Ildikó. 1998. "Ördögi mesterséget nem cselekedtem." A boszorkányüldözés társadalmi és kulturális háttere a kora újkori Debrecenben és Bihar vármegyében ["I have not done any diabolic deeds." The Social and Cultural Foundation of Witch-Hunting in Early Modern Debrecen and Bihar County]. Debrecen: Ethnica.

Lipsiai, Pál. 1610. Lex Politica Dei. Debrecen: n.p.

Macfarlane, Alan. 1970. Witchcraft in Tudor and Stuart England. A Regional and Comparative Study. New York and Evanston: Routledge \& Kegan Paul.

Magyar Törvénytár/Corpus juris hungarici 1000-1526. 1899. Budapes: Franklin Társulat.

Makkai, László. 1981. Puritánok és boszorkányok Debrecenben [Puritans and witches in Debrecen]. A Hajdú-Bihar megyei Levéltár Évkönyve VIII: 113-29.

Makkai, László. 1984. Debrecen mezöváros müvelödéstörténete [The cultural history of Debrecen] In Debrecen története 1 (1693-ig). Edited by István Szendrey. Debrecen: n.p., pp. 493-604.

Margitai Láni, Péter. 1617. Az Isten Törvenyenek, az Szent Iras szerint valo magyarazattya [The explication of the divine law according to the Holy Script]. Debrecen: n.p.

Mediomontanus Cimbalmos, János. 1656. Disputatio theologica de lamiis veneficis ... sub praesidio ... D. Georgii C. Comarini ... publice discutiendam proponit Joannes C. Mediomontanus. Varadini: n.p.

Melius, Péter. 1562. Confessio Ecclesiae Debrecinensis. In Kiss 1882. Budapest: Franklin Társulat, pp. 68-284.

Midelfort, Eric. 1972. Witch Hunting in Southwestern Germany 1562-1684. The Social and Intellectual Foundations. Stanford: Stanford University Press.

Monter, William. 1976. Witchcraft in France and Switzerland. The Borderlands during the Reformation. Ithaca and London: Cambridge University Press.

Muchembled, Robert. 1978. Culture populaire et culture des élites. Paris: Flammarion.

Muchembled, Robert. 1981. Les derniers bûchers. Un village de Flandre et ses sorcières sous Louis XIV. Paris: Ed. Ramsey.

Nógrádi, Mátyás. 1651. Lelki Probakő [Spiritual touchstone]. Debrecen: n.p.

Pápai Páriz, Imre. 1647. Keskeny Út [The narrow way]. Utrecht: J. Noortdijck.

Schram, Ferenc, ed. 1982. Magyarországi boszorkányperek (1529-1768) III [Hungarian witchcraft trials (1529-1768) III]. Budapest: Akadémiai kiadó.

Sz. Kristóf, Ildikó. 2013. Witch-Hunting in Early Modern Hungary. In The Oxford Handbook of Witchcraft in Early Modern Europe and Colonial America. Edited by Brian P. Levack. Oxford: Oxford University Press, pp. 334-55.

Sz. Kristóf, Ildikó. 2017. The social background of witchcraft accusations in early modern Debrecen and Bihar County. In Witchcraft and Demonology in Hungary and Transylvania. Edited by Gábor Klaniczay and Éva Pócs. Basel: Springer International Publishing AG, pp. 13-89.

Szúcs, István. 1871. Szabad királyi Debrecen város történelme I-III [The History of the Free Royal City of Debrecen]. Debrecen: n.p.

Thomas, Keith. 1987. Religion and the Decline of Magic. Studies in popular beliefs in sixteenth-and seventeenth-century England. London: Peregrine, (First edition 1973).

Trevor-Roper, Hugh. 1969. The European Witch-Craze of the 16th and 17th Centuries and Other Essays. New York: Harper \& Row.

Trócsányi, Zoltán. 1936. A történelem árnyékában [In the Shadow of History]. Budapest: Hungária.

TtREL. A Tiszántúli Református Egyházkerület Levéltára, Debrecen (Archives of the Diocese of Tiszántúl of the Refromed church).

(C) 2019 by the author. Licensee MDPI, Basel, Switzerland. This article is an open access article distributed under the terms and conditions of the Creative Commons Attribution (CC BY) license (http://creativecommons.org/licenses/by/4.0/). 
Article

\title{
Angels or Demons? Interactions and Borrowings between Folk Traditions, Religion and Demonology in Early Modern Italian Witchcraft Trials
}

\author{
Debora Moretti \\ Independent Scholar, Leeds LS27 8JW, UK; debsmoretti@hotmail.com \\ Received: 15 April 2019; Accepted: 9 May 2019; Published: 15 May 2019
}

\begin{abstract}
In 1638 Caterina di Francesco, from the town of Siena (Tuscany), was accused by the Roman Inquisition of invoking the devil through a spell called "the white angel spell" or "the spell of the carafe" (incantesimo della caraffa). She was interrogated, tortured and kept in and out of prison for nine years. Despite the accusations of the witnesses being focused on her practice of love magic, specifically her ability to bind men to "other" women rather than their wives and to help the disgruntled wives to have their husbands back with the use of a baptised magnet, the Inquisition focused its attention on her practice of the white angel spell, a divination spell to find lost or stolen objects with the help of shadows seen inside the carafe. This was a well-known spell not only among all levels of Italian lay society but also well known to the Inquisition, so much so that the 17th-century Inquisition manual Prattica per Procedere nelle Cause del Sant'Officio lists this spell among the sortilegij qualificati: Those spells presenting serious heretical elements. Using archival sources, this article will examine the effects of borrowed concepts between the theological/elite and folk witchcraft traditions within a specific case-study.
\end{abstract}

Keywords: Witchcraft; inquisition; spells; love magic; divination; sorcery

\section{Introduction}

The surge of European witchcraft studies characterizing the last two decades of historical research has created a new, reinvigorated interest in the topic among Italian scholars. This, substantiated by the opening of the Roman Inquisition archives in the 1990s, has contributed to a fresh approach to Italian witchcraft studies.

Before this period the status of the existing Italian literature regarding witchcraft studies reflected a sort of geographical fragmentation (Moretti 2018, p. 2). The north of the country, especially the Alpine area, being closer to the epicenter of the origins of the mythology of the sabbat and the witch-hunt phenomenon, has been covered abundantly by secondary sources (Olgiati 1955; Monter 1972; De Biasio and Facile 1976; Kieckhefer 1976; Monter 1976; Muraro 1976; Cardini 1979; Mazzali 1988; Martin 1989; Ginzburg 1990, 1991; Portone 1986; Marcaccioli Castiglioni 1999; Nardon 1999; Ostero et al. 1999; Kieckhefer 2000; Ankarloo and Clark 2002a, 2002b; Behringer 2004, pp. 57-63; Duni 2007; Kieckhefer 2006; Levack 2006, p. 4761; Panizza 1997, pp. 95-126; Lavenia 2015).

The rest of the country less so and more randomly (Tedeschi 1986; Moretti 2018, pp. 2-7).

All in all, the existing research has covered witchcraft in connection to other more orthodox and broader topics such as the interaction between witchcraft and medicine in early modern Italy and the importance of so-called witches in providing medical care and sometimes psychological support to those people who could not afford official medical care (Coltro 1983; Cardini 1989; Parinetto 1991; Gentilcore 1992; Gentilcore 1998; Cardini 2000; Pazzini 2001; Gentilcore 2004; Zucca 2004; Gentilcore 2008; Weber 2011; Corsi 2013; Lavenia 2014); the relationship between inquisitorial, episcopal and secular tribunals possessing jurisdiction over witchcraft and operating in the same geographical 
and political areas (Deutscher 1991; Del Col 1998; Black 2009; Deutscher 2013; Lavenia 2001; Trenti 2003; Lavenia 2015; Lavenia 2012; Caffiero 2015, pp. 33-66) and the role of the Roman Inquisition in maintaining this relationship with other tribunals (Romeo 1990; Prosperi 1996; Tavuzzi 2007; D'Errico 2012). Perhaps the most popular field among Italian historians—touching witchcraft obliquely-is the study of the Inquisition as an institution and its modus operandi in the handling of witchcraft cases among all other cases (Seitz 2001; Messana 2007). The most extensive and up to date scholarly publication on the history of the Roman Inquisition in the Italian peninsula, from its origin to its contemporary version, was carried out by Del Col (2006). Last but not least and worth mentioning, is the extensive corpus of scholarly publications regarding Italian witchcraft in the context of Renaissance natural and high magic (Walker 1958; Lavenia 2012; Montesano 2018).

Despite the large number of publications of which but a short list was given above, an opus magnum listing all the known witchcraft archives and relative trials region by region remains to be done. A survey of all the primary sources and their status - catalogued, published or neither-their location and accessibility with maps indicating the density of witchcraft trials similar to what Larner (1981) did for the Scottish witchcraft trials, would be a powerful tool for the understanding of witchcraft in Italy. Comparative analyses of the different typologies of Italian witchcraft would also be welcome. In this respect, the author's doctoral thesis wants to be one of the first steps in filling this gap (Kieckhefer 2006; Moretti 2018).

One of the most debated witchcraft-topics in the extant Italian literature is the historic argument regarding the trustworthiness of the trial documents as primary sources for the understanding of witchcraft in popular beliefs. Following the publication of his seminal work I Benandanti (The Night Battles: Witchcraft and Agrarian Cults in the Sixteenth and Seventeenth Centuries) (Ginzburg 1966), where in his research on the benandanti he applied the microhistorical approach which he would develop a few years later in his other historical best seller Il Formaggio e i vermi (The Cheese and the Worms: The Cosmos of a Sixteenth-century Mille) (Ginzburg 1976), historian Carlo Ginzburg affirmed that the trial records produced by ecclesiastic and secular tribunals could be compared to anthropologists' work-notes recording fieldwork performed a century ago (Ginzburg 1989, p. 156). He believed that the trials from Friuli have an extraordinary ethnographical importance. The inquisitors, to get to the "truth", recorded not only the words of their prisoners, but also gestures, silences and reactions almost as imperceptible as sudden blushing, and in reading them Ginzburg felt almost to be there, standing behind the shoulders of these inquisitors, spying on them and, as them, hoping to hear the accused talking of their secret beliefs. Ginzburg's theory was criticised by many, mostly by Italian historian Andrea Del Col.

Del Col forcefully cautioned historians dealing with the inquisitorial documents to keep a critical and cautious attitude. He explained that to be able to use these documents correctly it is essential to know the organisation, competence and the procedure of the organisation producing them. He rightly pointed out that the questions to be asked are how much these inquisitorial trials truly reflect how the interrogations happened in reality and how much they truly reflect the ideas of the inquisitors and the defendants. To be able to answer these questions, the documents need to be studied within their social and cultural contexts but also within the political and religious agenda of the organisation creating them. These trial documents cannot be seen as a verbatim report of the interrogation or as a recording made by a tape recorder. They were written down by notaries who had to understand the local dialect spoken by the defendants and sometimes interpret concepts not familiar to them or to the judges. Most importantly the judges, differently from anthropologists were not truly interested in the defendants' cultural background or beliefs (Del Col 1984, pp. 32-44; Nardon 1999, pp. 8-11).

Of course, these documents were heavily biased by the education, culture and personal agenda of the judges and inquisitors. Although very little analysed, the personality and culture of the individual inquisitor ended up having a fundamental importance in the trial proceedings. During the trials the defendants would get familiar with and influenced by the theological and personal interpretations given to magic and witchcraft by the judges (Keenan 1940; Bailey 2001) and they would include and 
absorb the judges' narrative into their own narratives which presents also some elements of their own folklore, beliefs and myths. On their part the judges would use their own experiences and what they have learnt of popular magic and witchcraft during the trials to write new manuals which will form the judicial educations of new judges and inquisitors creating "a circle of borrowed concepts" (Moretti 2018, p. 36).

The author believes that the confrontation of Del Col/Nardon's approach and Ginzburg's approach shows that their academic argument has a very important common element that cannot be ignored: as biased as the trial records might be, they are- together with material culture-still the closest and most direct records we possess of popular culture and beliefs at a specific point in time. And, although they give us "hardly a direct look at the views of the people questioned [ ... ] it is by far the closest access we have" (Lansing 2003, p. 90), and even if not strictly the truth, what was recorded in the trials had to be somewhat credible, and therefore acceptable, by the cultural parameters and understanding of the specific time in question (Moretti 2018, p. 38).

Following also the more recent focus on the inner lives and self-narratives of self-proclaimed witches/magic practitioners/cunning folks or those accused of magic/witchcraft practices connected to the history of emotions and selfhood currently characterising English speaking witchcraft studies and literature (Gaskill 2001; Gaskill 2008; Bever 2013; Kounine and Ostling 2017; Kounine 2018), the aim of this paper is to give a clear example on how, if read carefully and within the relevant context, some trials documents and inquisitorial documents can truly provide a glimpse-albeit minimalistic —on the perceptions and concepts of witchcraft beliefs from both the accused and the inquisitor and the more general cultural background within which these witchcraft beliefs and traditions were developed.

Many are the voices the historian hears and the recovery of the unbiased fragments of history from these voices can prove difficult. The essential job of the historian is to allocate those voices to the right cultural and social environment, and place them in their own context (Moretti 2018, p. 28). For this reason, the author of this paper will leave the accused, accusers and the authorities to unravel the story themselves.

\section{The Siena Inquisition}

The case study presented in this paper sits at the centre of the newly reinvigorating spur of studies caused by the opening of the Roman Inquisition archive in the 1990s (Accademia Nazionale dei Lincei 1998, 2000). Specifically, the witchcraft documents covered in this paper come from the Inquisition archive of Siena in Tuscany. The Roman Inquisition was established in Siena in 1570. The jurisdiction of the Sienese Inquisition included a geographical area bigger than the territories of the old republic of Siena (Di Simplicio 2000, pp. 17-24).

This archive was transferred to Rome in 1911 and it was re-discovered after the sensational opening of the archives of the Holy Office (Congregation for the Doctrine of the Faith) held by the Vatican, between 1991 and 1998. The archive of the Inquisition of Siena is almost intact and covers approximately two hundred years, from 1580 to 1780 . The entirety of this archive has allowed researchers to use its records to generate statistics of all sorts (shifting balances between types of prosecutions, gender of those prosecuted, urban versus rural offenders and so forth) from the mid-16th century to the late-18th century (Moretti 2018, p. 13). Examples of this approach are the outstanding works of the two leading experts on the archive of Siena: Di Simplicio $(1999,2000,2005,2009)$ and Nyholm Kallestrup (2015a, 2015b).

Witchcraft in Siena and its surroundings was a very simple concept. The maleficium was the main element. People were only concerned with the damage a witch could inflict on somebody rather than the demonic aspect of a witch. As result of this perception, the sabbat is extremely marginal in the Sienese archive. Of hundreds of people involved in the accusations and trials, nobody ever accused a witch of having a pact with the devil and of flying to the sabbat. Of eighty-one trials carried out between 1580 and 1666, only seven produced confessions of ten women who admitted participating in the sabbat. Seven of them admitted going to the sabbat only after torture and one was delirious 
with fever when she confessed but changed her confession after recovering from her illness. Only two women confessed "spontaneously" without torture (Di Simplicio 2000, p. 305). The invocation of the devil is in many cases a personal, innocent act of desperation or rebellion which does not present malevolent intent or, to a certain extent, predetermination (Moretti 2018, p. 120). Generally speaking, the Siena confessions are quite far from the amazingly elaborated tales of the sabbat of other European countries, rich in adoration of the devil, copulation with demons and cannibalism (Hutton 2017). Somehow, everyday people in Siena and surroundings were not interested in the devil or his relation with the witch. They were only concerned with the damage a witch could cause to their children, family, animals and harvest (Moretti 2018, p. 23). From the archive of Siena it is possible to understand that fear of maleficium was endemic and mainly coming from the lower groups of society, and it appears that the crime of maleficium is a "neighbourhood" crime, a crime that will be attributed to those people who will not conform to the standardised archetypical village behaviour (Briggs 2002, pp. 12-19, 77-79).

The full spectrum of witchcraft cases present in this archive has allowed the identification of at least five typologies of magical practices: (1) Love magic; (2) therapeutic/healing magic; (3) divinatory magic; (4) malevolent magic; (5) invocation of the devil. ${ }^{1}$

The case study analysed here falls in the typology of love magic and divinatory magic.

\section{The Case}

A very popular sortilegium in the New State of Siena was the spell of the carafe (incantesimo/esperimento della caraffa) which provided insight into stolen or lost objects and money. From the testimonies in other archival records, it seems in fact that this spell was also very popular in Venice and its domains, Bologna and very likely in the rest of Italy as well (Fioni 1992; Duni 2003).

On the 16th of October 1638, a disgruntled and rather upset wife presented a heart-felt accusation to the Inquisition tribunal of Siena. The accusation was carried out against "some loose/indecent women". Her husband, by his own admission, misbehaved towards her-by cheating on her and ignoring her-because he was a victim of bewitchment. In her rage-filled accusation, the wife did not question her husband's justification of his behaviour but instead she created a very convincing background, depicting him as the ultimate victim. She tells us:

Father, my husband, called [ ... ] is not giving me peace: he cannot stay with me and he does not want to see me, nor does he want to engage in any conjugal relations. And all this is caused by a connection he has with a certain woman called [ ... ], and this woman together with [ ... ] and Caterina Caponero, all three of them living in Siena in different locations, and they are known to be witches (the exact words used are maliarde and streghe). They have put a spell on him (the exact words used are ammaliato, affascinato, fatturato) and I know this because my husband himself told me when I complained of his ill behaviours towards me: leaving me to go to dirty whores, making me suffer but treating them well. He told me he cannot help himself, every time he tries to cut this connection and leave them, he feels like dying, dying in his heart, he cannot live nor be at peace without them and he is forced to go to them and do everything they tell him to do and they make him run to them.

(Moretti 2018, pp. 132-33). ${ }^{2}$

The wife carried out a double accusation: One, of the women having an affair with her husband and the other one, of the woman who provided the "other women" with evil love spells to bind the adulterous

1 To see the differences between the author's typologies and the typologies identified by Di Simplicio and Nyholm Kallestrup see (Moretti 2018, p. 120).

2 Congregation for the Doctrine of the Faith (ACDF) Archivium Inquisitionis Senensis, (Cause 1638-1646) 1, fos. 1-68; transcribed and translated by DM. The document transcribed is a copy of the trial itself: This means that it was for Caterina and her defense and it presents some lacunae, especially the names of the witnesses intentionally left out by the notary. 
man. What follows indicates an ambivalent and troubled relationship between the betrayed wife and the woman providing the evil, binding love spells:

This woman mentioned above [ ... ] uses the help of Caterina called Caponero, mentioned above, she lives in Salicotto, ${ }^{3}$ she is more or less fifty years old and she is the one who does maleficia. (Moretti 2018, p. 133)

Almost in the same breath she affirms:

I can confirm this (that Caterina practices maleficia) as a while ago, lamenting to her that my husband [... ] does not want to see me, he does not love me, he does not appreciate me, he beats me up and he never stays in the house with me, she (Caterina) said: "leave it to me. I will make sure that your husband will not be able to be with other woman but you". After that, she told me that she has bound him. (Moretti 2018, p. 133)

What we can understand from this first accusation is that our Caterina di Francesco known as Caterina Caponero was a middle-aged woman who lived in the Salicotto district of the town of Siena-an infamous district because it was favoured by prostitutes as a working and living location. Caterina was well known in Salicotto and other parts of Siena for practicing sorcery, love spells and magic bindings, for keeping bad company, favouring prostitutes and ultimately for being a woman of dubious and evil character-a loose woman. This last point makes sense if placed within the broader narrative related to prostitution and magical practices. It was rather normal for a practitioner of magic and sorcery in Early Modern Italy-and Europe-to have favoured prostitutes: they were good customers and represented good financial revenues for the practitioner. It was also rather normal for prostitutes to be practitioners of magic themselves. Their livelihood depended on their capacity to retain clients at all costs.

Caterina's situation appears frequently among the alleged witches ending up in front of the inquisitorial tribunals. Very often their status is that of "loose women" with no husbands, families or connections to support them in a society where female roles are extremely limited and censored (Ruggiero 1993, p. 25; Brown and Davis 1998; Bever 2002, pp. 955-88). In Siena, like Bologna, Venice and Modena for example, love magic was connected to prostitution (Zaffanella 2008, pp. 105-17). Love magic was not only an attempt to keep clients or attract more clients, it was also a way to supplement their income, and maybe, as stated by Scully (1995, p. 858) "witchcraft was a role available to women to manage their lives, operating as individual players on the social stage" although, on the basis of the testimonies above, it seems they choose this path only because they had no other choice (Moretti 2018, p. 138).

From the documents it seems that Caterina's most profitable "work" was indeed love magic, specifically her ability to bind men to "other" women rather than their wives and to help the wives to have their husbands back with the use of a baptized magnet. Clearly, she had a brain for good business.

An example of her profitable love magic comes from the accusing wife:

To make sure that her work was a success and to make sure my husband would love me, she sold me a piece of white magnet. She told me to touch my husband with it, and that I would keep it in my mouth while kissing him. Although Caterina Caponero sold the magnet to me, I never used it. I have heard from many people whose names I cannot recall, that this woman Caterina Caponero keeps under the capezzale 4 of the bed many strings to bind men with and other things to make maleficia. She has not only bound and put a spell on my husband, but also (on) a certain [ ... ] who tried to stop this connection (to practice sexual intercourse) with her [ ... ] but ultimately he cannot because he is saying he is spell-bound by her. (Moretti 2018, p. 133)

3 An area of Siena.

4 A thin, rectangular and narrow cushion to elevate the real pillow to a more comfortable position. Not much in use today. 
This is not the first time that Caterina is accused of love magic. The same disgruntled wife accusing her above, spontaneously appeared in front of the tribunal, at the suggestion of her confessor, to denounce some of her practices concerning the Holy Office-for which the confessor would not absolve her. The event took place eight years previously:

I came in front of the Holy Office because of the ill behaviour my husband had toward me, for the habit of drinking and getting involved with a certain prostitute called [ ... ] and others [... ] with whom he had connections and because of this he could not have marital relations, he could not stay at home and he told me he could not help it going there [ . . . ], (I) lamented this to [ ... ] who lived [ ... ] and is now dead, she suggested to me to do something about my husband and she mentioned Caterina Caponero, and she (Caterina) treated him. She brought to me a piece of stone as big as a cecerchia, ${ }^{5}$ grey or white-ish in colour, which she told me to be a baptised magnet. She said that if I put it in water I would have seen the stars and I would have recognised the moon. She also told me that when in bed with my husband, I had to put the magnet in my mouth and kiss him. In this way he would love me again. We kept this affair quite between me and her and no other person heard of it and I think I gave her [ ... ] as reward, because I did not have any money but I decided not to do anything with all this so I threw it in the [ ... ] and I was almost dead and shaken with fear, this not being the right way to do proper things, and I was almost dead and this [... ] told me that Caterina Caponero knew how to do those things and it is publically known that to her will go all those people that want to do maleficia or other things connected with binding and love. I presented myself in front of the Holy Inquisition also because before I [ . . ] the above mentioned magnet [ ... ] lamented to Caterina Caponero, above mentioned, and she said: "leave it with me, I will make it that your husband will not be able to have intercourses with women other than you" and she said afterwards that she bound him and (she) wanted him to love (me) and [ ... ] sold me a piece of white magnet [ ... ] baptised and with this I should touch [ ... ] and I should keep it in my mouth when [ ... ] kissed and [ ... ] him, I don't remember what I told him [ ... ] in truth nothing because he seemed to understand $[\ldots]$, because she was also a healer [ ... ] Caterina said she made herself the strings to bind these men and she would put them inside the cushions of these men when she could, and then she put ours (?) in the cushion, and if she could not go to those men's houses she would put the strings inside her pillow. I have heard the same things said by many other people but I don't remember exactly who but if necessary I could tell those things to Catherina's face, but, when we did our business and when she gave me the magnet, nobody was present .... (Moretti 2018, p. 136)

The tradition of love magic is of course ancient and wide spread (Luck 1985; O'Neil 1987; Wilson 2000) among the earliest Italian trials for sorcery, love magic and potions were the most obvious (Montesano 2018, pp. 186-90). The traditional use of the magnet in love magic but also in spells to attract money, success and power, is well attested in Early Modern Italy as seen in Tedesco's (2016) article on the use of baptized magnets in Italian Inquisition trials.

In this case study, both the accuser and the accused describe in detail how the spell of the magnet worked.

When the cheating husband was asked about Caterina he said:

I have heard things of Caterina Caponero from the Nigra called corvuccia, they are neighbours in Salicotto, and it seems they heal people and this is said by everybody but I do not remember who told me precisely. Sometimes I have been in the house of Caterina Caponero and I have

5 Very likely to be cicerchia: Lathyrus satious. 
heard other people [ ... ] saying that this Caterina could heal all illnesses, for this [ .. ], but I have never observed or saw Caterina doing or saying incantations ... . (Moretti 2018, p. 133)

So Caterina's fame seems to be well attested in the neighbourhood and the witness seems to be well acquainted with her. So much so that the cheating husband informs us:

I had experienced this (sexual) impediment not only with my wife, but with other women as well. I could not do it with anybody but the above mentioned women, with whom I would eat and drink together and with said [Caterina] of whom people said she was an enchantress. This was a while ago but I do not remember who I talked to about this. (Moretti 2018, p. 134)

In this passage it is possible to see the social role played by Caterina within her neighbourhood. It is publicly known that she is an enchantress, maliarda, practising love magic and healing and it is publicly known that she partakes of the company of loose women and her way of life is clearly upsetting some of her neighbours.

From Caterina's defence against the accusations of practicing love magic we can understand the deep social connection, interaction between the accusers and accused of witchcraft. The people in question knew each other and were involved socially with each other. If one was to interpret this connection in modern terms one would refer to a love-triangle badly managed. In Early Modern terms, the interpretation is more complexed and multi layered.

Caterina denied of course practicing love magic or magic in general. When asked directly she tells us:

No, I cannot do it (sorcery on men) nor do I know anybody able to do any sorcery to men or women so that they cannot have intercourse; these things against me are all lies of birri ${ }^{6}$ because this man birro and his wife Isabella (Isabetta) have ill feelings towards me as I have already said. And Busciati of [ ... ] is gone looking for women to testify against me and friar Giuseppe of St Martin persuaded them to be interviewed against me. The inspector told me in my house in front of my old mother while I was burning up, almost 20 hours with fever, last month of June and July. He came to check on me as I was just out of prison [ ... ] Busciati (spoke) with Caterina, wife of one from Fiorenzuola whose name I do not remember. She lives in the Chiasso of Anella in Salicotto and has a child called Matthia. Caterina herself was in my house soon after I was out of here (Holy Office prisons), only my old mother was present, she was coming here to help out. She told me that Busciati asked her if she knew if I did something dodgy and to tell him and he would refer it to the Holy Office without revealing her name. (Moretti 2018, p. 137)

She is clearly a person considered uncomfortable by some of her neighbours because of her practices which herself explains to the inquisitor when asked:

I healed many country folks, sbirri and whores of illnesses, in specific Monte Lupi and his wife who was mad and ran out once naked in the square and so did her sister. Just before I was due to re-enter the prison, I met with Monte Lupi's wife, near the door of Mr [ ... ] Bandini. She told me she was afflicted by solaggine (maybe heat stroke) and she asked me if I could give her a remedy for it. While I was treating the wife of Monte Lupi, called Maria, she moaned about problems with her husband. I told her that for those problems I could give her a white magnet which was given to me by Livia, for which I paid nine lire. My confessor told me to get rid of it but I did not get rid of it so Maria could have it if she wanted it and she should keep it in a certain way as I was told by Livia. (ibidem)

6 Sbirri/birri/birro: ante litteram police force. 
As not constituting a heretic practice, her work as a local healer seems to be irrelevant in the accusations and the inquisitor does not pursue it and refocus Caterina's attention on the love magic. So Caterina carries on:

This accusation comes from Elisabetta, wife of Mercurio sbirro. She sent two friars to my place to search the house and they told me that I was making a woman suffer and for this I should show them a capezzale where I was sleeping. I told them to go ahead and if they wanted me to open the capezzale, I would do so. They accused me of performing a binding on a man, making his wife suffer and thinking they were referring to Mercurio and Isabella, I told them: don't you think that if I knew how to bind him I would have done it already so he would marry me instead than punishing me. (Moretti 2018, p. 138)

Her logic is rock-solid and explicit. It also implies bitterness for a better life she could not have despite trying everything to have it and for a man she would never have: a love triangle and a social situation surprisingly common in the Inquisition trials related to witchcraft.

Caterina's implied self-narrative is however not heard and it is dismissed because it is not the magic spell per se to be the problem. It is the heretical act of baptizing an object to be used in a magic spell that ultimately will cost her freedom.

From St Augustine (Keenan 1940) onwards "for sorcery to fall under the purview of inquisitors, it had to manifest heresy, which generally meant the involvement of demons" (Bailey 2001).

For this reason, the accusations of love magic against Caterina Caponero are followed with accusations of divination. Or rather, the inquisitor questioning both accusers and accused focuses on those magical activities which would make Caterina guilty of heretical practices (Rosi 1898, pp. 10-25).

Her fame for the practice of the white Angel spell or spell of the carafe is widespread and three women testify against her.

The first one is Agnese. She is not only a witness but she is also implicated because she has done the spell herself. Her testimony is really important because it shows how much the spell of the carafe was popular in Siena and how it was connected to the presence of the devil in the carafe. She introduces herself saying: "My name is [Agnese], I live here in Siena and I am a cortiggiana, a whore that is". (Moretti 2018, p. 140).

Asked if she knew the reason why she was called here at the Holy Office and why she was interrogated she said she can imagine that it was because approximately a month ago, the person living above her lost some objects and she did the spell of the carafe to find what was lost.

Asked to explain this "experiment", this practice of the carafe, she said:

I sent somebody to get some holy water from the Duomo in a carafe. I put the carafe with the holy water on top of a table then I took and lit a holy candle from the candelora and then I asked the daughter of [ ... ] to say some words which are: White Angel, Black Angel, for my virginity, for my purity, tell me the truth, what is true, who has taken ... . (ibidem)

Asked by the inquisitor if she had carried out the same experiment after that time she said:

I did it one other time before that one, when I was a child of seven or eight years old. Caterina called Caponero of Salicotto from [ ... ] made me do it. These things we have learnt from [ ... ] I have never done it after these two times.

During her interview she blames Caterina for her bad ways:

I would like to repent with all my heart in the presence of God and I wish I could go back and undo what was done and I ask great penance and I am bitter and the Holy Office should punish that woman who taught me this, I have named her many times during the exam, she is Caterina called Caponero, she lives in Siena in the neighborhood of Salicotto, parish of St Martin, she is a tertiary of St Francis. She made me do the carafe for a woman called 
[Clementia] who lives in Siena and she made me... [two words have been penned out] and she did not want me to tell about this to [anybody] because, I believe it was an evil thing. (Moretti 2018, p. 141)

Asked by the inquisitor if she saw anything in the carafe she said: 'I do not remember seeing men in the carafe but black things which scared me and I fell sick for fourteen months after that'.

This is of course what the inquisitor was waiting for and from now on he tries to feed her responses although Agnese maintains her own ground explaining a little of her beliefs. When the inquisitor asked her what black things she saw she replied: 'I saw some things with horns and I believed it was the devil but they [Caterina and the others] stopped me and moved me away from there' (Moretti 2018, p. 142).

Asked by the inquisitor if she believed she was doing these orations to the devil she said:

I believe that we do these orations, invocations and reverences to the black Angels and to the white Angels whom I believe they all are in Paradise as I have seen it represented in the Duomo and the other churches. (ibidem)

This is a controversial statement and the inquisitor tries to lead Agnese in the right direction asking her if the black angels seen in the carafe had horns but she confirms: 'No my Lord and I venerate the black Angels as much as the white Angels because I think they all are from Paradise (ibidem).

With a more direct approach the inquisitor asks if she ever considered the black thing with horns she saw to actually be the devil and not a good Angel and she finally concedes:

[... I I recognize that also during that second time with that carafe we adored and invocated the devil and that we reverenced him to be able to know who had stolen [ ... ] I did it and I repent and I ask God for forgiveness as I know I did wrong. (ibidem)

She was eight years old when she did it the first time for Caterina Caponero. The second time she did the experiment of the carafe, it was before she was called to appear in front of the Holy Office so she had known this spell for all her adult life, accepting to a certain extent the negative implications of the spell but also understanding very well the necessity to cross the invisible line of what is good and pious into a darker territory for the success of the act performed: The recovery of material goods essential for survival. She has clearly seen the representations of angels and demons in the Duomo and she seems to imply that she understands that even demons were created in heaven therefore as useful as much as the angels in carrying out requests outside the sphere of human capability and power.

The second witness, Maria, tells us that two years after she was robbed by a man, a woman told her to consult Caterina to find the stolen object. Maria reluctantly accepted to have Caterina's help and goes to her house but she did not stay long because "I did not want to go up because I was hearing around that certain things could have been seen in the carafe" (Moretti 2018, p. 142). She did not see anything in the carafe because in the end she left before the conclusion of the spell. As payment for her help Maria would give bread and wine when Caterina went to visit her.

Cecilia's story, the third witness, is similar to Maria's. She had some objects stolen more than twenty years ago. Seeing her desperate some people suggested to her to seek the help of Caterina who could see in the carafe who took the stolen objects. She was not sure this was a good idea as she was told that Caterina was an evil woman and she was worried that her own husband would find out she frequented such a woman and would beat her up. She went anyway to Caterina's house and when there:

we went upstairs and entered a room without a bed and from what I remember it could have been a living room, and here we found with Caterina [Agnese] who, at the time, was a young girl of seven or eight years, together with other four or five young girls not known to me and I do not know who they were or what their names were, and I found that on top of a table there was a carafe full of water and [ ... ] looked inside the carafe and I do not 
know what she said and I cannot recall if she was on her knees or crouched, I only know that in the end she said "Jesus Maria! I see a man and a woman; one is lifting the chest lid and the other takes the stuff out and then puts back the lid". Caterina told me to look for myself and I did look but I did not say anything as I only saw my shadow and I did say to Caterina I only saw my shadow and I told her that I wanted to go away because I had left [ ... ] and it was the end of July or first day of August, I don't remember, and it was morning, approximately twelve o'clock, and maybe she [ ... ] gave Caterina an offer and [ ... ] I don't remember giving Caterina anything on that day but when she was coming at my place I would give her food and wine. And I remember even more: after the carafe Caterina told me the (stolen) stuff was nearby my house because those (thieves) seen in the carafe were not moving anywhere but they were sitting on the chest and I should send the authority right away and I asked: to whom should I send the authority and Caterina said: "to those you have closer to you and to those you think they are of [ ... ]. And I think I really did see them [ ... ] those, of whom I was suspicious, those who, after falling in misery came to ask for forgiveness for robbing me. But I did not mentioned them to Caterina and I told her I did not want to send him [policeman] to [ ... ], and she replied that I did not really care to have my stuff back and for this I should confess myself as it is a mortal sin (to lie?) and I did confess to the Father of our order of [ ... ] and he questioned me if I did see anything. I told him no and he replied [ ... ] over their conscience and he gave me the absolution and I do not recall anything else.

This testimony is important because it would prove the belief in Caterina Caponero's ability of divining through the spell of the carafe and the belief in the results of the spell itself but it is also testimony to the almost natural, everyday recurrence of magical thinking in Early Modern society.

As explained by Bailey (2001, p. 969) "After healing and warding off disease, the discovery of theft and the subsequent divination of the guilty party, or simply the location of a lost item if no theft was involved, were among the standard uses of common magic".

The spell of the white Angel and the carafe full of water was indeed well known and its use widespread in Italy across all levels of society. Even one of the most famous courtesans of Renaissance Italy-Veronica Franco, queen of the Venetian courtesans, loved by everybody and able to entertain the future king of France Henry III in 1574-was accused of witchcraft in 1580, for allegedly doing the spell of the white Angel to identify the person who had stolen goods from her house looking into a vase/flask (inchistara) full of water to which she freely admitted (Ruggiero 1993, p. 46).

In what is probably the most used inquisitorial manual in Italy, the Prattica per procedere nelle cause del Sant'Officio - a hand-written book in vulgar Italian dating to the first half of the 17th century based on the famous Instructio pro formandis processibus in causis strigam, sortilegiorum et maleficiorum, this spell is listed among the sortilegij qualificati, those spells presenting serious heretical elements:

Prostitutes [ ... ] practice the sortilegium of the carafe using virgin children, virgin spinsters or pregnant women, making them recite Holy Angel, White Angel, for your sanctity and my purity-and for the pregnant women the "virginity I have inside me". Often these spinsters and pregnant women said to have seen a figure or a shadow of some sort appearing inside the carafe which is interrogated to find stolen goods, hidden treasures or to know the future [ ... ]. (D’Errico 2008, p. 169; Moretti 2018, p. 144)

This is a well-known spell not only among all levels of Italian lay society but also well known to the Inquisition. In the eyes of the authorities, the ability to summon demons to reveal the thieves or to find lost goods implies a pact-implicit or explicit—with the devil. This is the reason why Caterina's accusers are questioned relentlessly.

Caterina herself is repeatedly interviewed with regard to this spell during the nine years of investigation while in and out of prison. During her interviews she mostly confirms her age-over fifty years old - that she is a spinner sometimes making extra money selling beddings and she is a 
tertiary of St Francis. This job, among others, was common during the Renaissance and Early Modern period in Italy.

When she is told about the testimonies against her, she admits knowing Agnese but she denies doing the experiment of the carafe with her or anybody else. When made aware of Agnese's testimony she says: "So it is because of that big whore that I am here".

Asked by the inquisitor about her connection to this prostitute she says: "I see her passing in front of my house all the time wearing a plumage (head gear) and a whore dress and for this particular, I have recognized her" (Moretti 2018, p. 144).

Again, from a social history point of view, this is a very important piece of information because from the end of the Middle Ages and throughout the Renaissance, prostitutes were required by legislation to wear specific clothing which would identify them as prostitutes and separate them from respectable women.

The inquisitor requests a face to face confrontation between Agnese and Caterina, with the former recognizing Caterina and Caterina refusing to recognize her and just saying: "I did nothing and I told the truth" (Moretti 2018, p. 145).

Refusing to recognize some of the witnesses and refusing to admit practicing the spell of the carafe, Caterina is forced in a face to face confrontation with Clementia, but she still denies knowing her. Only after the insistence and threats from the inquisitor Caterina tells the truth:

Father, it is true that I did the carafe for this woman, but I was young then and I did not have a brain, it was probably twenty-two or twenty-three years ago, I learnt it from a woman from Rome who is now dead, from her I heard the prayer [ ... ]; she was robbed of some things so she did the experiment and in a large group of young girls we went to see her and there I heard this [ ... ] she said and it was: "Jesus, Mary make me find my stuff". For now I cannot remember well but I will think about it and I will do [ . . ] being called. (ibidem)

Asked to explain in detail the experiment/spell of the carafe Caterina said:

I have done the experiment of the carafe and I did it this way: I prepared [ ... ] a carafe of holy water and I put it on an empty table, I put the carafe near the effigy of the Virgin Mary and I also took two leaves of holy olive and a holy candle. I lit the candle and I attached it to the table and then Agnese said: "beautiful Angel, white Angel, holy Angel, for your sanctity, for your purity, for my virginity, tell me the truth, who did this?" And the above mentioned, the one who confronted me this morning at your Lordship's bidding looked at the carafe and said those words [ ... ] many times, the above-mentioned Agnese saw in the carafe [ ... ] the devil [ ... ] and I learnt this experiment from a woman from Rome called Cecilia, she was a courtesan who died a sudden death (?) and I learnt it because I used to live near her and I used to visit her. I saw her doing this experiment of the carafe because she was robbed of some of her stuff by some men, one of her boys, more [ ... ] looked into the carafe, there were present a certain Lucretia Ferrarini a prostitute now dead, the woman [ ... ] in the converted (the converted were men and women who joined a convent, wore the religious garments but they did not take the vows. They would usually do the more humble jobs) of Bologna. When I did it for Clementia, the country peasant confronting me the day before yesterday, there were present Clementia herself, her friend (?) Petra, but only Agnese was kneeling down. (ibidem)

Asked her if she taught the experiment to Agnese she said: "Yes it is true that I taught her to say black Angel white Angel".

Asked to explain what does she means in calling the black angel and the white angel she said: "With the words black Angel I meant to call the devil".

Asked to explain the sanctity attributed to the black angel she said: 
In this case we give the devil the title (?) of saint and sanctity, even if I know the devil is no saint, just so he can reveal to us who the thief is. I was aware that in doing the action of the carafe we were adoring the devil and that it was a sin. I do not remember telling Clementia that it was a sin but I do remember well telling Agnese when she came to pray when I did the experiment of the carafe for Clementia. Having learnt how to do it from Cecilia and having heard Cecilia saying many bad things while she was doing the carafe, I told Agnese it was a $\sin$ and she asked me please to do it and to teach her to do it because Clementia was poor. Agnese herself brought the carafe with the holy water into my house and we did it because the abovementioned Clementia was robbed of certain things but I did not ask her what.

Asked her if she thought it legitimate to invoke demons she said:

I do not think it is legitimate, in fact I do believe it is a sin, but back then I did think it was legitimate because I did not think I was doing evil. I believed that to be able to know who the thief was, it was legitimate to do everything possible and I believed that the devils spoke and revealed where and who took the robbed stuff.

This passage is extremely important to understand Caterina's beliefs-and those others practicing the same spell or any another spell invoking the devil—regarding the reality of the devil: The devil is subordinate to her, it is a means to get what is needed and wanted. She needs a supernatural power to help her out and it does not really matter if it is God, an angel, a saint or the devil, as long as she is able to cope with the hardship of her life.

This spell was certainly part of her status within the social milieu of Salicotto because she tells us:

It would be probably over twenty-one years ago I did the carafe for Clementia. I did not do the carafe again and I did not teach it to anybody else. It is true that I went around the streets saying: Ladies, I know how to do the carafe in the Roman way and I laughed. But I was not telling how to do it. For this reason Cecilia, the Roman woman sent a friend of hers to beat me up and he wounded me in the head; another woman [ ... ] told me that these things cannot be said but then I had very little brain, being at that time still (young).

Her fame spanned two decades and it was widespread within her neighborhood. Caterina herself spread the word around and people clearly made use of her love magic, divination and healing.

The trial document does not tell us the punishment Caterina suffered, but a letter of the inquisitor from Rome-Giulio Roma - to the inquisitor of Siena—Francesco Sertorio da Castel Fidardo-regarding this case and dated Rome 24 February 1647 says:

Reverend father, you must submit Caterina Caponero to more torture pro ulteriori veritate usu, conplicibus et intentiones. If she keeps to her ways, before the abjure de vehementi, she must be flogged without taking in consideration the unmarried niece. ${ }^{7}$ Agnese must stay inter missarum solemnia at the church door with a lit candle in her hand and must abjure de levi in secret. Clementia and Maria must be discharged with admonitions and beneficial penitence. This is what the council of the Holy Office have agreed upon. May God keep you. (Di Simplicio 2009, Letter 999, p. 275-Translated from Italian to English by DM)

This is a severe sentence compared to our modern context and parameters, considering the nine-year period for the duration of the trial. If, however, we put this sentence in an Early Modern context and more specifically within an inquisitorial context—-we see how Caterina did indeed tick all the boxes to be accused of heresy and apostasy.

7 Alleged witches with unmarried daughters or other female relatives would get punished in secret to prevent the "witchcraft" stigma affecting future marriages. 
In the Prattica per procedere nelle cause del Sant'Officio we find a description of qualified sortilegij (heretical) and non-qualified sortilegij (not really heretical). Specifically, qualified sortilegij are those where there is evidence of the invocation of demons, obscure words or signs, abuse of sacraments and of sacramentals, use of human or animal blood, following of the lunar phases, inappropriate use of the name of God and the saints. The non-qualified ones are those where orations contain the name of God and crosses and passages from the Bible for protection. We also find that: "under the same name of sortilegij are included also witches (male and female) practicing maleficia on people in different ways, love or death and [killing] little children".

Furthermore the author of the Prattica specifies that although witches would sometimes use words, objects and rituals typical of a more benign love magic (sortilegij ad amorem) for their maleficia ad amorem, in the majority of the cases their practices have a more sinister and dangerous nature where adjuration of demons feature heavily, contributing to the ultimate demise of their victims.

This implies therefore a well-defined and well perceptible differentiation between sortilegij and maleficia and for this reason and so for simplicity I differentiate it as being between sorcery and witchcraft; following therefore more modern generalized criteria which see sorcery as both harmful and beneficial magic, while witchcraft is seen always as harmful magic.

To understand better the concept of heresy among ordinary people and the ordinary clergy, specifically connected to the spell of the carafe it is perhaps appropriate to hear the words of a clergyman implicated in an earlier case of this type of spell. Between April 1580 and January 1581 Margherita di Mariano from San Gosme, wife of Cesare, the amphorae maker, and Paola wife of Ambrogio Milanese were accused of invocation of the devil and sorcery done with the carafe and abuse of holy water and candles. They were tried and flogged and then they were asked to abjure de vehement. They were prosecuted because they were asked to carry out the spell to help the friars of the order of the Servi di Maria to recover stolen items (Moretti 2018, p. 128). It was the prior of the Servi di Maria who commissioned one of the two women to find the lost goods.

Interesting is therefore the position of the prior of the convent of the Servi, friar Fabiano who ordered this spell to be done:

I did not witness the spell or divination you are telling me about but I know very well that this spell was done because a certain Messer Caio came and told me that as said by a woman, these tovaglie and stagni could be found without spending money, but only with a carafe, he did not tell me that this carafe had to be full or empty, only that a carafe was enough for such a trade. (Moretti 2018, p. 131)

When asked by the inquisitor if he knew why he was called in front of the tribunal he said: 'because of the enmity and hate among the friars although in my part, I have forgiven everybody' (ibidem).

Although a friar, at first he seems to have no idea on what must constitute heresy and superstition in the eye of the church, his church. He ordered people to make sure this spell would happen; he ordered that the materials necessary to do the spell should be delivered to the woman and he gave permission to two young friars to participate in the spell and saw no danger of heresy in it. The inquisitor picked on this and asked him if he believed divinations to be diabolic to which friar Fabiano replied:

I believe them to be superstitions but if they are diabolic or not, I refer to the holy church and therefore they are heretical things. I believe that these images and apparitions are diabolical because a man would not fit in a carafe, and I have never had anything to do with demons, knowing that it is not allowed [... ]. (ibidem)

So he is fully aware, but as long as he is not physically present, then he is not a heretic. This, as we have seen in the above interrogations, is a straight forward, matter of fact and to a certain extent convenient perception of theological ideas. The perception everyday people-including religious people - of what was good and bad differenced substantially from the perception of the theological 
elite (Roper 2006). The boundaries between angels and demons, religion and witchcraft and heresy and orthodoxy were blurred in the face of life struggles. Even the devil, within the limits of common magic and witchcraft, seems to become an instrument in the hands of the practitioner.

In Siena, as Venice, Modena and Bologna, the invocation of the devil and other supernatural agencies like the angels, the white/evening star or even ancient pagan gods like Zeus and Mars were popular, especially so among religious people (frustrated nuns and greedy priests and friars), nobility (frustrated women and greedy men) and literates. It is however obvious that the invocation of the devil seems to be connected to blasphemy and rebellion rather than demonic witchcraft.

Despite the new religious and spiritual interest, during the 16th and 17th centuries, in angels and demons and the increasing fascination of the fallen angel who is no longer a terrifying monster but a familiar figure sharing people's anxieties and sufferings, the devil seems to have a secondary importance as supernatural agency in witchcraft archives. And despite the church teachings and the sermons, for the common folks he offers an alternative to a brutal existence and albeit transient and illusionary, this alternative - the power to perform magic practices-fascinated people who embraced the mythology of this alternative thinking into their everyday lives, transforming the devil from ultimate supernatural agent to a dispenser of dreams and all-time favourite scapegoat. There is almost a sense of domestication of the devil, a figure which no longer is the supreme master of the witches, ultimate dispenser of evil and dark powers as featured in the most famous of the demonological treaties, but a figure whose supernatural agency can be easily replaced by others making the invocation and adoration of him, not a heresy but a practical and functional act.

Funding: This research received no external funding.

Acknowledgments: I am grateful to Marina Montesano for the opportunity, the reviewer for the feedback and Victoria Carr, Sherridan Morgan and Tommy Kuusela for the support.

Conflicts of Interest: The author declares no conflict of interest.

\section{References}

Accademia Nazionale dei Lincei. 1998. L'Apertura degli Archivi del Sant'Uffizio romano. Giornata di Studio promossa dall'Accademia dei Lincei e della Congragazione per la Dottrina della Fede. Rome: Accademia Nazionale dei Lincei.

Accademia Nazionale dei Lincei. 2000. L'Inquisizione e gli Storici: un Cantiere Aperto, Tavola Rotonda nell'ambito della Conferenza annuale di ricerca. Roma 24-25 giugno 1999. Rome: Accademia Nazionale dei Lincei.

Ankarloo, Bengt, and Stuart Clark, eds. 2002a. Witchcraft and Magic in Europe. The Middle Ages. London: University of Pennsylvania Press, vol. 3.

Ankarloo, Bengt, and Stuart Clark, eds. 2002b. Witchcraft and Magic in Europe. The Period of the Witch Trials. London: University of Pennsylvania Press, vol. 4.

Bailey, Michael. D. 2001. From Sorcery to Witchcraft: Clerical Conceptions of Magic in the Later Middle Ages. Speculum 76: 960-90. [CrossRef]

Behringer, Wolfgang. 2004. Witches and Witch-Hunts: A Global History. Cambridge: Polity Press.

Bever, Edward. 2002. Witchcraft, Female Aggression and Power in the Early Modern Community. Journal of Social History 35: 955-88. [CrossRef]

Bever, Edward. 2013. Realities of Witchcraft and Popular Magic in Early Modern Europe: Culture, Cognition and Everyday Life. London and New York: Palgrave Macmillan.

Black, Christopher. 2009. The Italian Inquisition. New Haven: Yale University Press.

Briggs, Robin. 2002. Witches and Neighbours: The Social and Cultural Context of European Witchcraft. Oxford and Malden: Blackwell Publishing.

Brown, Judith C., and Robert C. Davis, eds. 1998. Gender and Society in Renaissance Italy. London and New York: Longman. Caffiero, Marina. 2015. Magia, Superstizione, Religione: una questione di confine. Rome: Edizioni di Storia e Letteratura.

Cardini, Franco. 1979. Magia, Stregoneria, Superstizioni nell'Occidente Medievale. Florence: La Nuova Italia.

Cardini, Franco, ed. 1989. Gostanza, la strega di San Miniato. Processo a una guaritrice nella Toscana mediecea. Bari: Laterza.

Cardini, Franco. 2000. Radici della Stregoneria: dalla protostoria alla cristianizzazione dell'Europa. Rimini: Il Cerchio. 
Coltro, Dino. 1983. Dalla magia alla medicina contadina e popolare. Florence: Sansoni Editore.

Corsi, Dinora. 2013. Diaboliche maledette e disperate. Le Donne nei Processi per Stregoneria (secoli XIV-XVI). Florence: Florence University Press.

D’Errico, Gian Luca. 2008. I sortilegi. In Sortilegi amorosi, materassi a nolo e pignattino: Processi Inquisitoriali del XVIII secolo fra Bologna e il Salento. Edited by Umberto Mazzone and Claudia Pancino. Pisa: Carocci Editore, pp. 119-72.

D’Errico, Gian Luca. 2012. L'Inquisizione di Bologna e la Congregazione del Sant'Uffizio alla fine del XVII secolo. Rome: Aracne editrice.

De Biasio, Luigi, and Maria Rosa Facile, eds. 1976. 1000 processi dell'Inquisizione in Friuli (1551-1647). Udine: Villa Manin di Passariano, Centro regionale di catalogazione dei beni culturali.

Del Col, Andrea. 1984. I processi dell'Inquisizione come fonte: Considerazioni diplomatiche e storiche. Annuario Istituto Storico Italiano per l'età moderna e contemporanea 35: 3-51.

Del Col, Andrea. 1998. 'Le strutture territoriali e l'attività dell'inquisizione romana. In L'Inquisizione, Atti del Simposio Internazionale, Città del Vaticano, 29-31 ottobre 1998. Edited by Andrea Borromeo. Vatican City: Biblioteca Apostolica Vaticana, pp. 345-81.

Del Col, Andrea. 2006. L'Inquisizione in Italia. Dal XII al XXI secolo. Milan: Mondadori.

Deutscher, Thomas. LXXVII/1991. The Role of the Episcopal Tribunal of Novara in the Suppression of Heresy and Witchcraft (1563-1615). The Catholic Historical Review 3: 403-21.

Deutscher, Thomas. 2013. Punishment and Penance. Two Phases of the Bishop's Tribunal of Novara. Toronto, Buffalo and London: University of Toronto Press.

Di Simplicio, Oscar. 1999. L'inquisizione di Siena e le accuse di maleficio. In Metodologia delle fonti e storia Istituzionale. Edited by Andrea Del Col and Giovanna Paolin. Trieste: Edizioni Università di Trieste, pp. 256-73.

Di Simplicio, Oscar. 2000. Inquisizione, Stregoneria, Medicina. Siena e il suo Stato (1580-1721). Monteriggioni: Il Leccio.

Di Simplicio, Oscar. 2005. Autunno della Stregoneria. Maleficio e magia nell'Italia moderna. Bologna: Il Mulino.

Di Simplicio, Oscar, ed. 2009. Le Lettere della Congregazione del Sant'Ufficio all'Inquisitore di Siena 1581-1721. Inquisizione e Società-Fonti-3. Trieste: Edizioni Università di Trieste.

Duni, Matteo. 2003. Magia, esorcismi e cultura popolare nel primo Cinquecento nei processi dell'inquisizione modenese. In Per il Cinquecento Religioso. Clero, Cultura, Società, Atti del Convegno Internazionale di Studi, Siena, 27-30 Giugno 2001. Edited by Maurizio Sangalli. Rome: Edizioni dell'Ateneo, pp. 501-12.

Duni, Matteo. 2007. Under the Devil's Spell. Witches, Sorcerers, and the Inquisition in Renaissance Italy. Florence: SUF.

Fioni, A. 1992. L'inquisizione a Bologna. Sortilegi e Superstizioni popolari nei secoli XVII e XVIII. Carrobbio 18: 141-50.

Gaskill, Malcolm. 2001. Witches and Witnesses in Old and New England. In Languages of Witchcraft: Narrative, Ideology and Meaning in Early Modern Culture. Edited by Stuart Clark. Basingstoke, London and New York: Macmillan Press, pp. 55-80.

Gaskill, Malcolm. 2008. The Pursuit of Reality: Recent Research into the History of Witchcraft. Historical Journal 51: 1069-88. [CrossRef]

Gentilcore, David. 1992. From Bishop to Witch. The System of the Sacred in Early Modern Terra d'Otranto. Manchester and New York: Manchester University Press.

Gentilcore, David. 1998. Healers and Healing in Early Modern Italy. Manchester: Manchester University Press.

Gentilcore, David. 2004. Was There a "Popular Medicine" in Early Modern Europe? Folklore 115: 151-66. [CrossRef]

Gentilcore, David. 2008. Malattia e guarigione. Ciarlatani, guaritori e seri professionisti. La storia della medicina come non l'avete mai letta. Nardò: Controluce.

Ginzburg, Carlo. 1966. I Benandanti. Turin: Einaudi.

Ginzburg, Carlo. 1976. Il Formaggio e i vermi. Turin: Einaudi.

Ginzburg, Carlo. 1989. Clues, Myths, and the Historical Method. Baltimore and London: John Hopkins University Press.

Ginzburg, Carlo. 1990. Deciphering the Sabbath. In Early Modern European Witchcraft: Centres and Peripheries. Edited by Bengt Ankarloo and Gustav Henningsen. Oxford: Claredon Press, pp. 119-37.

Ginzburg, Carlo. 1991. Ecstasies: Deciphering the Witches' Sabbath. Chicago: The University of Chicago Press.

Hutton, Ronald. 2017. The Witch: A History of Fear, from Ancient Times to the Present. New Haven and London: Yale University Press. 
Keenan, Mary. 1940. The Terminology of Witchcraft in the Works of Augustine. Classical Philology 35: $294-97$.

Kieckhefer, Richard. 1976. European Witch Trials: Their Foundations in Popular and Learned Culture, 1300-1500. London and New York: Routledge.

Kieckhefer, Richard. 2000. Magic in the Middle Ages. Cambridge: Cambridge University Press.

Kieckhefer, Richard. 2006. Mythologies of Witchcraft in the Fifteenth Century. Magic, Ritual and Witchcraft 1: 79-108. [CrossRef]

Kounine, Laura. 2018. Imagining the Witch: Emotions, Gender and Selfhood in Early Modern Germany. Oxford: Oxford University Press.

Kounine, Laura, and Michael Ostling. 2017. Emotions in the History of Witchcraft. London: Palgrave.

Lansing, Carol. 2003. Concubines, Lovers, Prostitutes. Infamy and Female Identity in Medieval Bologna. In Beyond Florence: The Contours of Medieval and Early Modern Italy. Edited by Paula Findlen, Michelle M. Fontaine and Duane J. Osheim. Stanford: Stanford University Press, pp. 85-100.

Larner, Christina. 1981. Enemies of God: The Witch-Hunt in Scotland. London: Johns Hopkins University Press.

Lavenia, Vincenzo. 2001. "Anticamente di misto foro". Inquisizione, Stati e delitti di Stregoneria nella prima età moderna. In Inquisizioni: percorsi di ricerca. Edited by G. Paolin. Trieste: Edizioni Università di Trieste, pp. 35-80.

Lavenia, Vincenzo. 2012. Stregoneria e Inquisizione. In I vincoli della natura: Magia e Stregoneria nel Rinascimento. Edited by Germana Ernst and Guido Giglioni. Urbino: Carocci Editore, pp. 185-202.

Lavenia, Vincenzo. 2014. Inquisitori e streghe, teologi e medici. In Astrologia e magia nel Rinascimento. Teorie, pratiche e condanne. Edited by Germana Ernst e Guido Giglioni. Pisa: Il Campano, pp. 117-53.

Lavenia, Vincenzo. 2015. The Alpine Model of Witchcraft: the Italian Context in the Early Modern Period. In Communities and Conflicts in the Alps from the Late Middle Ages to Early Modernity. Edited by Marco Bellabarba, Hannes Obermain and Hitomi Sato. Bologna-Berlin: Il Mulino-Duncker \& Humblot, pp. 151-64.

Levack, Brian. P. 2006. The Witch-Hunt in Early Modern Europe. London and New York: Routledge.

Luck, George. 1985. Arcana Mundi: Magic and the Occult in the Greek and Roman Worlds. London: Crucible.

Marcaccioli Castiglioni, Anna. 1999. Streghe e roghi nel Ducato di Milano. Processi di Stregoneria a Venegono Superiore nel 1520. Milan: Thélema Edizioni.

Martin, Ruth. 1989. Witchcraft and Inquisition in Venice: 1550-1650. Oxford and New York: Basil Blackwell.

Mazzali, Tiziana. 1988. Il Martirio delle streghe: una nuova drammatica testimonianza dell'inquisizione laica del Seicento. Milan: Xenia Edizioni.

Messana, Maria Sofia. 2007. Inquisitori, negromanti, e streghe nella Sicilia moderna, (1500-1782). Palermo: Sellerio.

Monter, William. 1972. The Historiography of European Witchcraft: Progress and Projects. Journal of Interdisciplinary History 2: 435-51. [CrossRef]

Monter, William. 1976. Witchcraft in France and Switzerland: The Borderlands during the Reformation. London and Ithaca: Cornell University Press.

Montesano, Marina. 2018. Classical Culture and Witchcraft in Medieval and Renaissance Italy. Cham: Palgrave Macmillan.

Moretti, Debora. 2018. The Witch and the Shaman: Elements of Paganism and Regional Differences in Italian Witches' Trials. Ph.D. Thesis, Department of History (Historical Studies), University of Bristol, Bristol, UK.

Muraro, Luisa. 1976. La Signora del gioco. Episodi della Caccia alle streghe. Milan: Feltrinelli.

Nardon, Franco. 1999. Benandanti e Inquisitori nel Friuli del Seicento. Trieste: Edizioni Università di Trieste.

Nyholm Kallestrup, Louise. 2015a. Crossing Boundaries: Constructing the Witch in Early Modern Italy and Denmark. In Prescritto e proscritto: Religione e società nell'Italia moderna (secc. XVI-XIX). Edited by Andrea Cicerchia, Guido Dall'Olio and Matteo Duni. Rome: Carocci Editore, pp. 43-64.

Nyholm Kallestrup, Louise. 2015b. Agents of Witchcraft in Early Modern Italy and Denmark. Basingstoke: Palgrave Macmillan.

O'Neil, Mary. 1987. Magical Healing, Love Magic and the Inquisition in Late Sixteen century Modena. In Inquisition and Society in Early Modern Europe. Edited by Stephen Haliczer. London and Sydney: Croom Helm, pp. 88-114.

Olgiati, Gaudenzio. 1955. Lo Sterminio delle streghe nella valle Poschiavina. Poschiavo: Tip. Menghini.

Ostero, Martine, Agostino Paravicini Bagliani, and Kathrin Utz Tremp. 1999. L'imaginaire du sabbat. Edition critique des textes les plus anciens (1430 ca-1440 ca). Lausanne: Cahiers Lausannois d'Histoire Médiéval, vol. 26, BFSH 2. 
Panizza, Gian Maria. 1997. Triora 1587-1590: bilancio di una ricerca e prospettive per ulteriori indagini. In Oltre Triora. Nuove ipotesi di indagine sulla stregoneria e la caccia alle streghe. Atti del convegno, Triora-Toirano 29-30 ottobre 1994. Varese: Reggiani, pp. 73-92.

Parinetto, Luciano. 1991. Solilunio. Erano donne le streghe? Rome: Pellicani.

Pazzini, Adalberto. 2001. Demoni, Streghe e guaritori: il mistero di un mondo popolato di esseri visibili e invisibili. Turin: CeT.

Portone, Paolo. 1986. Cinque processi di stregoneria nella diocesi di Como (1579-1580). Quaderni Milanesi Studi e fonti di storia lombarda 11: 27-60.

Prosperi, Adriano. 1996. Tribunali della coscienza. Inquisitori, confessori, missionari. Turin: Einaudi.

Romeo, Giovanni. 1990. Inquisitori, esorcisti e streghe nell'Italia della controriforma. Florence: Sansoni Editore.

Roper, Lyndal. 2006. Witchcraft and the Western Imagination. Transaction of the Royal Historical Society 16: 117-41. [CrossRef]

Rosi, Michele. 1898. Le Streghe di Triora in Liguria. Processi di Stregoneria e relative questioni giurisdizionali nella seconda metà del secolo XVI. Rome: Tipografia delle Mantellate.

Ruggiero, Guido. 1993. Binding Passions: Tales of Magic, Marriage and Power at the end of the Renaissance. New York and Oxford: Oxford University Press.

Scully, Sally. 1995. Marriage or a Career? Witchcraft as an Alternative in Seventeenth-century Venice. Journal of Social History 28: 858-76. [CrossRef]

Seitz, Jonathan. 2001. Witchcraft and Inquisition in Early Modern Venice. Cambridge: Cambridge University Press.

Tavuzzi, Michael. 2007. Renaissance Inquisitors. Dominican Inquisitors and Inquisitorial Districts in Northern Italy, 1474-1527. Leiden-Boston: Brill.

Tedeschi, John. 1986. The Disperse Archive of the Roman Inquisition. In The Inquisition in Early Modern Europe. Studies on Sources and Methods. Edited by Gustav Henningsen and John Tedeschi. Dekalb: Northern Illinois University Press, pp. 3-32.

Tedesco, Vincenzo. 2016. “Una Pietra della Quale Si Servono le Genti Cattive". Inquisizione e Sortilegi a Siena nella Prima Età Moderna. Rivista di Storia della Chiesa in Italia 2: 425-46.

Trenti, Giuseppe, ed. 2003. I processi del tribunale dell'Inquisizione di Modena. Inventario generale analitico 1489-1784. Modena: Aedes Muratoriana.

Walker, Daniel P. 1958. Spiritual and Demonic Magic from Ficino to Campanella. London: The Warburg Institute.

Weber, Domizia. 2011. Sanare e Maleficiare. Guaritrici, Streghe, Streghe e Medicina a Modena nel XVI secolo. Rome: Carocci.

Wilson, Stephen. 2000. The Magical Universe: Everyday Ritual and Magic in Pre-Modern Europe. London: Hambledon and London.

Zaffanella, Valeria. 2008. Società e socialità. In Sortilegi amorosi, materassi a nolo e pignattino: Processi Inquisitoriali del XVIII secolo fra Bologna e il Salento. Edited by Umberto Mazzone and Claudia Pancino. Pisa: Carocci Editore, pp. 105-17.

Zucca, Michele. 2004. Donne delinquent: Storie di streghe, ribelli, rivoltose, tarantolate. Naples: Edizioni Simone.

(C) 2019 by the author. Licensee MDPI, Basel, Switzerland. This article is an open access article distributed under the terms and conditions of the Creative Commons Attribution (CC BY) license (http://creativecommons.org/licenses/by/4.0/). 


\title{
Article \\ "Paltrie Vermin, Cats, Mise, Toads, and Weasils": Witches, Familiars, and Human-Animal Interactions in the English Witch Trials
}

\author{
Helen Parish \\ Department of History, University of Reading, Reading RG6 6AH, UK; h.l.parish@reading.ac.uk \\ Received: 31 January 2019; Accepted: 19 February 2019; Published: 23 February 2019
}

\begin{abstract}
This article explores the role played by the relationship between witch and familiar in the early modern witch trials. It positions animal familiars at the intersection of early modern belief in witchcraft and magic, examining demonologies, legal and trial records, and print pamphlets. Read together, these sources present a compelling account of human-animal interactions during the period of the witch trials, and shed light upon the complex beliefs that created the environment in which the image of the witch and her familiar took root. The animal familiar is positioned and discussed at the intersection of writing in history, anthropology, folklore, gender, engaging with the challenge articulated in this special issue to move away from mono-causal theories and explore connections between witchcraft, magic, and religion.
\end{abstract}

Keywords: witchcraft; familiars; popular belief; animals; demonology; witch trials

The mental and physical space occupied by the stereotypical early modern 'witch' lies at the intersection of popular culture and inquisitorial anxiety, drawing upon a longstanding lexicon of faith, folk belief, night flights, magic, devils, and demons. The witch embodied and enabled conflict and contradiction, reflecting and creating anxieties about the nature of humanity, social order, heresy and heterodoxy, and the language of opposition between good and evil in moral and theological terms. In the hands of demonologists, inquisitors and law-makers, the multiple components of the archetypal witch crystallised around the imagery of the 'demonic pact', the personal relationship between the witch and devil, and the all-encompassing vocabulary of maleficium which made real these ideas in popular culture and social communities. In the character and actions of the witch, religion, ritual, magic, law, and social tensions intersected, creating a shared belief in the constructed enemy of Christian society. The vocabulary of demonologies, statute, and judicial processes made its way into popular culture, a culture that perpetuated and solidified that language by proving it to be anchored in the reality of the day-to-day. The presence of witchcraft and magic at the 'crossroads' of early modern belief has been well documented in recent years, and our appreciation of the complexities of early modern witchcraft has greatly enhanced as a result (Bailey 2003, 2006, 2007; Behringer 1997; Broedel 2003; Clark 1997; Cohn 2000; Edwards 2002; Montesano 2018; Kieckhefer 1976, 1996).

Within that more nuanced appreciation of the multiplicity of ideas and anxieties from which the image of the witch emerged lies the witches' 'familiar'. The presence of the familiar in the witch trials is an almost uniquely English phenomenon, but it is one that raises important questions about the nature and practitioners of witchcraft, the role of demons and the demonic in the actions of witches, and the challenge that witchcraft and familiars posed to traditional categorisations and assumptions around human and non-human interactions. Keith Thomas' assertion that the presence of animal familiars in the English witch trials is 'largely unaccounted for' remains almost as accurate thirty years later (Thomas 1971, p. 569). However, it is worth noting that the witches' Sabbat, so prevalent in the records of continental witch trials, was almost entirely absent from the English narratives in 
this period. Instead, the relationship between witch and devil was displayed in the contact between the human witch and the animal familiar, a relationship which in many respects presented a material embodiment of the demonic pact. The familiar acted a hybrid of learned demonological anxieties about human commerce with demons, and a popular culture and folklore that positioned animals, imps, and fairies as intermediaries between humans and the numinous supernatural. Animal familiars made it possible to elide well-articulated views about demonic magic with the broader range of practices and supernatural encounters associated with cunning men and women. Animal familiars, treated as pets and companions, were not innocent participants in the practice of witchcraft, but creatures with agency, demons in corporeal form, whose interactions with the witch were problematic both conceptually and practically. Familiars were evidence of the permeable boundary that existed between humans and animals, the presence of demonic ritual and blood-feeding among practitioners of magic, the moral and theological depravity of witchcraft, and the transgression of nature that lay at the heart of the witch. As a result, the narrative of the familiar, and the search for physical evidence of interaction between witch and familiar became a vibrant thread in English witchcraft narratives. Specific reference to the actions of witches who nourished and rewarded their 'spirits' found its way into English law in 1604, positioning the familiar as an almost mandatory element in the armoury and reputation of the witch.

The Act against Conjuration, Witchcraft and dealing with evil and wicked spirits, (1 Ja. I c. 12) issued in 1604 identified as felons 'any persons or persons [who] shall ... use, practice, or exercise any invocation or conjuration of any evil or worked spirit, or shall consult, covenant with, employ, feed, or reward any evil and wicked spirit to or for any intent or purpose ...' . The relationship between the person and the familiar was, in law, evidence of witchcraft itself. The specific reference to feeding or rewarding an evil spirit in the Jacobean legislation was an important moment in the definition of witchcraft in England. Before his accession to the English throne, James' views on magic and witchcraft had been presented in the Daemonology, and in the pamphlet News From Scotland, which included references to weather magic, nocturnal flight, and the presence of animal familiars in the practice of witchcraft. But while the reference to the feeding of evil spirits in the 1604 Act was the first explicit reference to the 'familiar' in English law, the association between witchcraft and demonic familiars had a longer ancestry. Familiars featured in vernacular pamphlet literature circulating in England in the 1560s, laden with contemporary colour culled from the trials of witches, and echoing the longer history of the relationship between witches, demons, and animals. The familiar was much more than a construct of early modern demonology, informed by the language of the demonic pact, and its application to the contractual interaction between the human witch and non-human, or demonic, creatures. Rather, the relationship between witch and familiar, and the representation of that relationship, grew out of, and informed, the relationship between religion, magic, folk belief, and learned demonology in late medieval and early modern Europe. The witch's familiar was to become a common feature of early modern witchcraft literature, but, like much of the language and imagery that defined beliefs, the familiar sat at the intersection of ideas, assumptions, and fears about magic, demons, and the nature of the human witch.

Like many components of early modern witchcraft, the relationship between the witch and the familiar had a long ancestry. A digression in William of Malmesbury's Gesta regum Anglorum (c.1123), is often regarded as the first written reference to the relationship between witch and familiar (William of Malmesbury and William 1887, an.1125 Bk.2, §204; Coxe et al. 1841, an.852). In his narrative of the so-called 'witch of Berkeley', William of Malmesbury described a witch's corpse, torn from its tomb by violent demons, and conveyed to Hell by a demonic horse. This was no accident; the so-called 'witch' had, in her lifetime been known to practice divination, particularly 'ancient augury' a form of divination involving birds. She was also, in the chronicler's words, 'excessively gluttonous, perfectly lascivious, setting no bounds to her debaucheries', and although not old, certainly in declining health. As she neared the end of her life, she made elaborate provisions for the treatment of her body after death. The medieval church took a dim view of augury and divination, and the witch, appeared to 
recognise the impact of her actions upon the fate of her soul, describing herself as 'the sink of every vice.' She summoned her pious children (both of whom were in holy orders) to make every effort to preserve her body, even if the 'sentence was already passed' on her soul. Her children were instructed to sew her corpse into the skin of stag, and lay it upon its back inside a stone sarcophagus in the parish church. The lid was to be weighed down with lead and iron, and the fortress-like sarcophagus bound with three heavy iron chains. Psalms were to be sung for fifty nights, and Mass to be said for her soul. On the fourth day, her body was to be removed and buried in the ground. However, the fears of the witch were realised, as demons burst into the church, broke the chains, and tore her body from its refuge. Thrust onto iron barbs on the back of a black horse waiting outside the church, the woman's body was conveyed away with the demons, her cries audible up to four miles away. The narrative had multiple meanings, which ebbed and flowed in later re-tellings of the tale. In many respects, the story is simply a medieval morality tale, in which the punishment for sin reflects the nature of the offence against God (Russell 1972, p. 99). However, given the propensity of medieval chroniclers to weave the supernatural and wondrous into narratives in order to make a polemical point, William of Malmesbury's inclusion of the Berkeley story might also be read as a judgement upon the political disruptions of the age and the symbolic judgement of God. By the end of the eighteenth century, the witch had become part of English literary folklore in Richard Southey's ballad, 'A Ballad, shewing how an old woman rode double, and who rode before her', later reprinted in Matthew Lewis' Tales of Wonder (1801). Southey's attribution of the original story to 'Matthew of Westminster' is erroneous, but his reference to the appearance of the witch in the works of Olaus Magnus and in the Nuremberg Chronicle is a useful pointer to the early modern re-telling of the tale (Magnus 1555, book 3 c.21). Clearly, the story of the witch of Berkeley and her communion with animals and demons was capable of speaking to many audiences.

The first recorded witch trial in which explicit reference is made to the use of a familiar in witchcraft is that of Dame Alice Kyteler, in 1324 (Wright 1833, p. 2). But the Kyteler case is an isolated instance; it was two centuries later before familiars were to become a distinctive feature of witch beliefs. This integration of the familiar into the narrative of witchcraft evolved as a result of the osmotic relationship that existed between demonological writings, popular culture, ecclesiastical law and secular statute. The demonisation of animals as "familiars" was fuelled by the circulation of discussions of magic and witchcraft in print, within the broader context provided by early modern confessional and secular imperatives, and debates over the nature of animals and animal-human relations. The appearance of the devil to a witch in the form of an animal was to become a common feature of accusations of witchcraft, confessions, and trial records (Amphlett Micklewright 1947, p. 286). The presence of animals in witchcraft belief has been described as a 'peculiarly English' phenomenon, but it is one that illuminates the ongoing interactions between religion, magic, witchcraft and folklore across in a broader sphere (Creagor and Jordan 2003, p. 157; Thomas 1983). The interplay between witch and familiar presented evidence of the corporeality of demons, and thus the demonic nature of witchcraft. While such connections between witch and demon were an integral component of early modern European demonology, the roots of the demonic familiar lay less in learned theological tomes, and more in the landscape of popular belief. Published in 1523 in defence of a witch hunt that had claimed ten victims, Giovanni Pico della Mirandola's Strix sive de ludificatione daemonum included reports of witches who could assume animal form, but presented such belief as folklore rather than objective fact. The Dialogue took the form of an interrogation of an accused witch by two humanists, one convinced of the reality and threat of witchcraft, and the other a sceptic. The presiding judge, confronted by the discussion of animal familiars, dismissed such accounts as 'empty, with no basis in reality.' (Pico della Mirandola and Perifano 2007, F1r; Stephens 2016) Mirandola was, by the time the Dialogue was published, familiar with the now infamous work of two Dominican theologians and inquisitors, The Malleus Maleficarum, to which he referred three times in his text. However, despite the detail and range of the Malleus, its authors offered very little comment upon the interaction between animal and human in the domain of witchcraft, other than the potential harm that witches could 
cause to animals, and a description of a witch who was accompanied to her place of execution by a raven. Similarly, brief discussion is to be found in Francesco Maria Guazzo's Compendium Maleficarum, published a century later. Guazzo, a priest with some experience in bewitchment, possession and exorcism, made only passing reference to witches seated at the sabbath, each with a 'familiar spirit'. Such spirits might assume an animal form, he noted, but the Compendium contains no explicit reference to the more colourful stories told about relationships between witches and familiars, or the more specific matter of spirits receiving nourishment from the witch (Guazzo and Summers 1988, p. 15). The French jurist and philosopher Jean Bodin included passing references to demon spirits and familiars in his De la démonomanie des sorciers, including a description of toads kept by witches in pots, but despite the length and detail of his analysis of demonic pacts, the narratives are again sparse and without the vibrant colour that attended accounts of the English familiar (Bodin 1587, book 2.3). The French inquisitor Nicholas Remy presented a more detailed description of the birds, crabs, hares, mice and birds associated with the practice of witchcraft, but we should not discount the possibility here that Remy's evidence for such interactions came from the evidence presented in trials, and accusations made against witches by neighbours. The relationship between learned demonological treatises, legal structures, and popular belief was often circular rather than unidirectional; it was possible for the judicial process to shape a broader cultural understanding of witchcraft and familiars, and for the evidence presented in accusations and trials to exert an influence over legislative and theoretical constructs of witchcraft (Serpell 2002, p. 187).

Similarly, the prominent role played by the animal familiar in English witch belief and trials is only occasionally evident in early modern English demonological writing. The churchman Henry Holland's Treatise Against Witchcraft (1590) drew upon Bodin's demonology, among others, but was also informed by the English context, a desire to eradicate folk magic, and a wish to respond to Reginald Scot's rather more sceptical assessment of witchcraft and magic in England. Constructed as a dialogue between the God-loving 'Theophilus', and devil-loathing (and Scot-citing) 'Mysodaemon', Holland's work was wideranging. But the dialogue and debate are not laden with references to animal familiars, and where the term 'familiar' is used, its use is not specific enough to denote an animal or minor demon. The terminology does, however, refer to interactions between the witch and the devil, and in his discussion of the Old Testament locus classicus for the evils of witchcraft, the witch of Endor, Holland argues for the existence of a demonic being with whom the witch co-operated, suggesting that 'there must be to cooseners at the least, so there are and the witch is on, the deuil an other.' The role of animals as the agents through which witches might fly to the sabbath is discussed, but within the broader context of the journey, assisted sometimes by ointments, goats, horses or brooms, and sometimes without (Holland 1590, C1). The presence of the familiar in Williams Perkins' treatise on the damned art of witchcraft is likewise transitory. Perkins starting point was the assertion that witchcraft was a common sin, exploited by Satan in diverse ways that ranged from a deliberate contract or pact, to seemingly innocuous but in reality diabolic superstitions. Perkins notes that marks on the body of the witch, putatively evidence of a demonic pact, might be read as a sign of guilt, but offers no detailed explanation of how these marks were created. The pact with the devil was, in Perkins' mind, the first proof of witchcraft, but the presence of a familiar, a spirit in a visible, bodily form 'mouse, catte, or some other visible creature, was the second (Perkins 1608, pp. 186, 203). The animal familiar featured more prominently in a longer discussion of the corporeality of the devil, but in this case it is possible to observe the influence of statute upon demonology; Perkins' work appeared in print shortly after the link between witch and familiar had been articulated in the Witchcraft statute of 1604 . Witch belief in the English context is indicative of the existence of a syncretic relationship between oral tradition, judicial processes, pamphlet literature, and legislative process. That same relationship is evident in the voices of scepticism raised against the English witch trials. If the devil were indeed so terrible and powerful, George Gifford suggested, why might his minions take the form of 'paltrie vermin, cats, mise, toads, and weasils'? (Gifford 1593, pp. 22-23) 
These 'paltrie vermin' might have been largely absent from English demonologies, but by the seventeenth century, lurid details of the interactions between a witch and a familiar had become a commonplace in English witch trials and the popular print literature that accompanied them. Some three quarters of such trial accounts made reference to familiars (Murray 1970, p. 85; Briggs 2002, Sharpe 1997, p. 137). Familiars appeared in a variety of forms in these sources, and the power attributed to witches and their maleficent familiars was extensive. Familiars appeared most commonly depicted as animals, occasionally in human form, familiars appeared in some instances as a hybridisation that both reflected and shaped their demonization. These creatures served as a point of intersection between humanity and the devil, orchestrating a relationship between the material actions of the witch and the supernatural origins of such power. The maleficent actions of familiars occupied the physical and mental space that was traditionally filled by the devil in the writings of demonologists; it was the familiar that tempted the individual, secured a contractual arrangement with the promise of assistance in return for allegiance, and then enabled the witch to inflict harm upon neighbours and communities.

These familiars, although demonic, often took a mundane form. Animal familiars came in various shapes and sizes, but by far the most common were mice, cats, dogs, and even toads, all animals that were both ubiquitous, and common as domestic companions (Thomas 1983, pp. 100-12; Herzig 2010). The use of 'watching' in the mid-seventeenth century trials often led to accusations that the witch possessed a mouse as a familiar, a pattern identified by Serpell (2002), and interpreted as a result of natural causation. Sitting and observing a prisoner during the day and night, a 'watcher' was highly likely to find their attention caught by a rodent. That same association between witchcraft, magic, and mice continued to hold purchase over the popular imagination long after the end of the witch trials in England, with reports of practitioners of magic who kept white mice as familiars, and passed them to relatives.

Insects, particularly bees and flies, were also identified in witch trials and demonologies as familiars and agents of demonic activity. An early account of a pseudo-familiar from 1510, for example, detailed the actions of a schoolmaster at Knaresborough (Yorkshire), who kept three spirits in the form of bumble bees, feeding them with blood let from his fingers. In 1654, Elizabeth Roberts was accused by John Greencliffe of Beverly of keeping familiars taking the likeness of a cat and of a bumble bee 'which did very much afflict him, to witt, in throwing of his body from place to place notwithstanding there were five or six persons to hold him downe' (Raine 1861, p. 67). The Demonic familiars in the form of insects featured prominently in the trial of Rose Cullender and Amy Duny in Bury St Edmunds (1662) at which it was alleged that 'a thing like a bee flee' had caused the child to fall into a fit, vomiting a nail that she claimed had been forced into her mouth by the bee. Flies also swarmed around the child, forcing her to swallow pins. Another witness claimed to have been affected by 'lice of an extraordinary number and bigness' when passing Rose Cullender's house (Anon 1664). Plagues of lice and other insect familiars also featured in the trials of Alicia Warner or Rushmere, Joan Wayte (1650) and Susannah Smith. The association between witches and insect familiars could extend beyond the personal to impact upon a broader landscape, causing crop damage, famine and social dislocation. Guazzo's Compendium Maleficarum described the use of insects by witches who were inspired by the devil to pervert nature by 'infesting the trees and fruits with locusts, caterpillars, slugs, butterflies, canker-worms, and such pestilent vermin which devour everything, seeds, leaves, fruit' (Weiss 1930, p. 127; Guazzo and Summers 1988, Book 2 c.1). This is not surprising; the association between failed harvest, hunger, and fear of witchcraft has been well documented (Behringer 1995). The irritant and destructive power of insects was attested in nature and Scripture, enabling their role to shift readily from agents of providential judgement to enactors of maleficent destruction (Exodus 22:28, Joshua 24:12, Deut. 7:20).

A similar intermingling of natural observation, common reputation, and fear of the demonic is evident in the frequent references to toads as familiars in early modern witchcraft literature. The devil, 'who squat like a toad at the ear of Mother Eve in Eden' was believed to wait in churchyards in the hope that a communicant, emerging from church, would feed it part of the consecrated bread 
(Kittredge 1929, pp. 180-82). The association of toads with demonic magic grew out of a broader cultural understanding that extends well beyond the chronology of the witch hunt. Toads featured prominently in popular belief and legend, often linked with illness. The assumption that toads were poisonous was well established, but toads were also believed to possess curative medicinal properties, as in Shakespeare's As You Like It: 'the toad, ugly and venomous, Wears yet a precious jewel in his head' (Shakespeare et al. 2015, Act 2 Scene 1). Toads were used to treat a variety of ailments, including plague, abscesses, nosebleeds, sprains, smallpox, and the king's evil. Pliny's Natural History, which was to become a model for encyclopaedists of natural history in the medieval and early modern period (xxxii. xviii) commended the use of bones from the legs of toad as an aphrodisiac, and as a means of fending off wild dogs. Advice to consume toads 'given in some pleasant or delightsome drinke', appeared in Edward Topsell's The Historie of Foure-Footed Beastes (1607), the first full length English encyclopaedia of natural history (Topsell 1607, p. 515). Given the potential for subjectivity in the separation of practitioners of magic from practitioners of medicine and healing, references to toads in early modern witchcraft were commonplace. In 1580, at the execution of an accused witch in Steiermark, observers note the appearance of a toad, unusually large, rushing from the fire to find water (Petzoldt 1990, p. 116). At the trial of Ursula Kempe in St Osyth (1580), her son described her four familiars, including a toad named 'Pigin' who had caused a young child to fall ill. In Stradbroke, Suffolk, Joan Jorden was reportedly bewitched by three toads; the first prevented her from sleeping, the second was destroyed by fire, and the third caused its victim to fall downstairs, falling unconscious, and giving onlookers the sense that she had been possessed (Wright and Wright 2005, p. 13; Notestein 2003, p. 313). Toads were added to witches' cauldrons, most notably to create the unguent that was used to enable night flight; 'Toad, that under cold stone, Days and nights has thirty-one Swelter'd venom sleeping got, Boil thou first i' the charmed pot' (Institoris and Sprenger 1486; Shakespeare and Hunter 2015, Act 4 scene 1; Allen 1979, pp. 256-58). In the descriptions of the Sabbath that featured prominently in early modern European denunciations of witchcraft, the baptism of toads was presented as evidence of the depravity and sacrilege that attended such gathering (Allen 1979, pp. 265-66; Monter 1997). The trial of John Walsh for witchcraft in 1566, recorded evidence of the use of toads as familiars, and the use of the toad for demonic purposes was assured a cultural longevity by the reference to Paddock, a toad familiar, in the opening scene of Macbeth. The use of such creatures by witches in order to inflict harm upon not just individuals but whole communities present further evidence of the position of familiars as a point of intersection between learned demonologies, popular belief, social need and religious context.

How was it that common, domestic, animals came to play such a prominent role in witch belief in this period? Again, it is worth considering the broader backdrop against which such ideas evolved; the history of familiar lies at the intersection of debates over the natural world, human-animal relations, magic, and social pressures (Wilby 2000, p. 300). Keith Thomas' magisterial study of the relationship between man and nature identifies the domestication of animals as a key indicator of changing attitudes to animal-human interactions. The practice of keeping of animals as 'pets' had traditionally been confined to courtiers, nobles and members of the higher clergy; for the rest of the population, animals were kept for more functional reasons, undertaking physical labour in order to serve the needs of humans. However, the popularisation of the practice of keeping animals as companions, and for emotional and sentimental reasons, changed the position of animals in human society and the relationship between man and nature. The boundary between animals as pets and animals as familiars was certainly permeable, with the relationship between witch and familiar often framed by a requirement to care for animal (Sax 2009, p. 327).

The keeping of some animals as pets required a carefully articulated separation between domesticated animals and 'beasts.' The separation was in part linguistic; animals whose contribution to human society was practical and functioned tended to have names that were descriptive (sheep, horse, cow) whereas animals with which humans formed a more emotional bond were given more personal, 'pet' names (Creagor and Jordan 2003, p. 54; Kean 2012). Farm animals were physically separated from humans, and a lack of segregation seen as 'very beastly and rudely in respect of civility' 
(Thomas 1983, p. 94). This transition, it has been argued, encouraged the rejection of assumptions and practices that had attributed a religious or magical value to non-human creatures (Bulliet 2005, p. 181; Sax 2009, p. 327). Children were often prohibited from crawling on all fours for fear that they become less human by mimicking animals (Klaits 1985). In this context, it is possible to see how practitioners of magic and witchcraft might be assumed to be engaging in interactions between animals and humans that were deemed to transgress social norms. The animal familiar inhabited the physical margins of human society and the cultural and religious boundary between orthodoxy and deviance. On one side, an animal could be domesticated, a pet, and a source of companionship, but on the other, a sign of corruption and the inversion of appropriate beliefs and relationships. Contact with animal familiars both exposed and enabled the corruptions of the witch.

The animal familiar had the potential to make the witch appear less human, almost bestial in character and nature. This theme is particularly evident in the inversion of female characteristics in the image of the witch; women who nurtured familiars rather than children, feeding a suckling familiar transgressed social, cultural, and moral norms. Blood feeding was presented as the means by which the witch provided sustenance to the familiar, but it was also the pivot of the rewards promised for acceptance of the devil's demands. The confessions of the witches of Windsor (1579-80) reflected this permeable boundary, with the descriptions of the feeding of familiars as both basic sustenance and covenant-based suckling. The suckling of familiars also conjured images of suckling infants, juxtaposing immoral or demonic actions upon images of godly Christian motherhood and care for infants. Worse still, the connection between blood and the life of the soul in the Judaeo-Christian tradition deepened the sense of sin that accompanied reports of blood-feeding. Whether the witch shed blood to feed an animal or a demon, such actions were morally and theologically dangerous. Feeding blood to an animal inverted the natural order, and imbued the creature with a quasi-human status as the recipient of human blood. To feed blood to a demon was indeed to offer one's soul to the devil, and such actions presented tantalising proof of the corporeality of the devil that was exposed by interactions between animal familiars and witches (Leviticus 7:27 and 17:11-14). A pamphlet account of the trials that took place in Chelmsford in 1566 provided a detailed account of the three women accused of witchcraft, and their connections with their familiar, described as a white spotted cat named Satan. Nourished by drops of their blood, the cat had brought material objects to the women, but had also inflicted harm upon members of the community, causing illness, and even death. The cat had been passed from grandmother to grandchild, with instructions that it be kept in a basket, and fed with bread and milk. Of the three accused witches, Agnes Waterhouse confessed to witchcraft and was hanged; Elizabeth Francis was imprisoned for one year, and required to stand on the pillory on four occasions, and Joan Waterhouse was acquitted. In the examination of Agnes Waterhouse, the feeding of blood to the familiar loomed large in her testimony. Agnes described how 'every time he did any thinge' for her, a demand was made for a drop of her blood. Pricking her body to release the blood, Agnes was left with a permanent mark on her skin. Under pressure from the presiding judge, Agnes attempted to withdraw her testimony, but the skin on her face and head was revealed to be marked with such spots where her familiar had fed upon her blood recently, but 'not this fortnight' (Phillips 1566, Part 2, A7v; Serpell 2002, p. 178; W. W. 1582).

Such accounts fuelled and were fuelled by the practice of searching the body of witches. Four men and sixteen women were convicted of witchcraft at the Lancaster Assizes in 1634; of the women, thirteen were searched for a physical mark in their bodies that might present evidence of interaction with devils and demons. Four were conveyed to London, where they were examined by midwives under the supervision of a group of physicians including William Harvey. Their examination concluded that only one of the women presented with unusual marks on her body, but that even these were not 'un natural.' Such determined searching for evidence of physical contact between the witch and her familiar presents one of the clearest illustrations way in which oral culture could be intermingled with theological and moral concerns about the physical nourishment of familiars by witches. John Walsh, put on trial for witchcraft in 1566, was a practitioner of medicine and surgery, but also immersed in 
a world of magic, fairies, and numinous beings. He described human communication with fairies at designated hours of the day, and complex rituals that smacked of the learned ceremonial magic of court magicians. Under examination, Walsh provided an account of the use of wax images and pictures which had been 'tempered all in water in which toads have been washed' which could be used to bring harm and injury. Such maleficent magic required the toad to swell in order to perform the 'evil act.' He also confessed to having fed drops of blood to his familiar. Walsh asserted that he could summon a spirit by using a book that he had inherited from his father, and reported that the spirits took various forms when they appeared. Such summons were only successful if issued by the master, equipped with the book itself, candles, and other ritual objects, in a narrative that was redolent with the language of the learned magic of the Middle Ages. But the intention was presented clearly as a pact; Walsh described how 'the first time when he had the spirit, his said master did cause him to deliver him one drop of his blood, which blood the spirit did take away on his paw' (Ewen 1933, pp. 146-47; Purkiss 2001, p. 82; Lüthi 1976, p. 68). This reciprocal arrangement between witch and familiar, the contractual language with which it was described, composed a demonic refrain for the domestic voices in the English witch trials. Blood-feeding in return for reward was described in a language that intersected with that used to represent the demonic pact in continental demonologies, but the use of that language in the English trial narratives was integrated into a longer tradition of popular belief about the relationship between humans, animals, and evil spirits. The use of blood in narratives of magic had its roots in much older accounts of the provision of corporeal strength to the dead and to spirits, and the feeding relationship between witch and familiar reflected broader popular beliefs around the role of animals in human contact with the supernatural and the materiality of spirits in animal form. That same symbolism of food and feeding was used in early modern continental demonologies in which the material feeding confirmed and symbolised the spiritual pact in which the soul was surrendered to the devil, to the point at which the nurturing of animals exemplified and evidenced the inversion of the divine order by witches and their animals demons (Sax 2009, p. 318; Wilby 2000, p. 287; Ewen 1933, pp. 72-73).

The physicality of the familiar, which embodied the pact between witch and devil, derived from the requirement that devils and demons acquire a tangible form in order to engage in physical contact with the witch and cause material harm. The animal familiar therefore had agency in the orchestration of their meeting with a human accomplice (Serpell 2002, p. 158). In many witchcraft narratives, an individual was approached by an animal, often while alone or distressed, with a promise to alleviate social or material suffering in return for the co-operation of the witch. Such agreements amounted to a pact with the demonic familiar, and lead to acts of harm and destruction. During the Chelmsford witch trials, women confessed that they had been promised material gifts, including money and livestock, in return for the renunciation of their baptismal promises and rejection of Christian salvation (Anon 1589). In the case of Elizabeth Stiles, one of those accused of witchcraft in Windsor, her acceptance of the promise of material wealth from her familiar precipitated a series of maleficent acts including murder and infanticide (Anon 1579). Stiles repeated a discussion with her familiar in which she had asked 'that she might be ryche and to have goodes' and 'Sathan' promised to deliver her request' - 'Sathan' would 'do what she would command' or 'do for her what she would have him do.' When she found herself pregnant, Stiles asked the Satan to abort the pregnancy, and took her familiar's advice to consume a 'certayne herb' which brought the pregnancy to an end. In August 1645, self-appointed witch-finder John Stearne sent five witches from Ratlesdon, Suffolk, for trial in Bury St Edmunds, including Meribell Bedford, who confessed that a 'black thing' had visited her, 'which asked her to deny God and Christ, and told her, if she would, she would never want.' The agreement between witch and devil, described as a 'covenant', was sealed by blood from Meribell's little finger, at which point further creatures appeared to her (Stearne 1648, p. 26). By the publication of the fourth edition of his Countrey Justice in 1630, Michael Dalton was content to make full use of the theological presentation of the relationship between witch and familiar as a form of demonic pact. The work of the churchman Richard Bernard provided Dalton with language and evidence that was first expanded and then employed as part of the 
judicial process against witches. The actions and writings of Stearne, Dalton and Bernard are indicative of the way in which such fears surrounding familiars were anchored in the reality of the witches' confessions, and the potential for the familiar to act as the point of intersection between popular belief and demonological and judicial anxieties (Bernard 1629; Dalton 1630, p. 276).

Although the demands made by familiars often contained hallmarks of the demonic, particularly the witch's blood, many simply mirrored the standards of general care for animals. Familiars were nourished not only with blood, but with milk, bread, water or beer. Images in printed pamphlets depict witches suckling familiars, but also feeding them, sometimes with a spoon, confined in a box (Anon 1579, title page). The language of the pact, and the relationship between the witch and the familiar further domesticated and anthropomorphised the animal. Familiars acquired their own nomenclature, often being given human names (Wilby 2000, p. 288; Anon 1579). Mary Hockett, interrogated as a witch by Matthew Hopkins, confessed to keeping three mice as familiars, named "Littleman," "Prettyman," and "Daynty" The practice of naming animals was part of a process of domestication, but the naming of familiars also marked out these creatures as a source of companionship for individuals who lived on the edge of human society. As Keith Thomas observed, familiars "may have been the only friends these lonely old women possessed, and the names suggest an affectionate relationship" (Thomas 1971, p. 523). Such affectionate integration of animal familiars into the commerce of human environment has echoes in the form of communication between witch and familiar. Such contact was often verbal, with conversations recorded and reported in detail during the interrogation of suspected witches (Phillips 1566, p. 17). Elizabeth Francis, accused in Chelmsford in 1566, described how her familiar had advised her to 'renounce God and his word, and to give of her blood.' The testimony of Agnes Waterhouse, at the same trial, presented a picture of her relationship with the cat familiar that was similarly contractual and verbal in nature. At her trial, Agnes confirmed that she had received the cat from Elizabeth Francis, with the promise that 'yf she made much of him, he would do for her what she wolde have him do.' When Agnes found that 'being moved by poverty' she could no longer provide her familiar with a bed of wool, she successfully persuaded the animal to assume the form of a toad. Agnes' daughter, Joan, confessed that she had found herself at home alone and hungry, having been refused food by a neighbour's child. Joan described how she had then done what her mother had done, and summoned the familiar Satan, to frighten the girl into handing over food. In return, Satan demanded that Joan promise him her body and soul. Helen Clark, accused in the Essex witch trials of 1645 , described how her dog familiar had appeared to her at home with the verbal request that she renounce God and deliver it her soul (Wilby 2000, pp. 291-94). Testimony from the 1582 trial of Ursula Kemp included an account of her familiar, Tiffin, had engaged in detailed conversation with her about other local witches and their familiars, reporting the harmful acts that they had committed together. Such conversations between witch and familiar provide a compelling example of the anthropomorphism that was often involved in the relationship between the witch and the familiar, and the personal and particular nature of the communication between the two.

Matthew Hopkins' account of his witch-hunts in East Anglia, The Discovery of Witches (1647) described a range of animal familiars whose appearance gave little cause for comment, but on occasion the animal possessed unusual features. Such creatures appeared almost monstrous, a physical manifestation of the moral distortion of the witch. Agnes Francis kept as a familiar a toad, or 'a thynge lyke a blacke dogge with a face like an ape, a short tail, and a peyre of hornes.' During her trial, Agnes' daughter described how she had seen her mother carrying 'the thing' in her hands. (Ewen 1933, pp. 143-46). Elizabeth Francis' familiar, although shaped like a dog, had unusual horns Hopkins' description of 'Vinegar Tom' attributed to him a horned head 'like an Oxe' (Hopkins 1647, p. 2). Other animals were over-sized, including several toads. In the printed account of the Lowestoft witch trials, two of the named familiars, Lyerd and Suckin, appeared in the form of a dog and a lion. In the same trial, Ursley Kempe confessed that she had been tricked into thinking that her white lamb was always truthful. Her son testified that she kept four spirits in animal form, the lamb, a toad, and two cats, but his description of these creatures as 'like a toad', or 'like a cat' suggests that these creatures occupied a liminal state between 
animal and non-animal form (W. W. 1582). Such aberrations were unlikely to be mere accidents; as the visual stereotype of the devil became more homogenous in the late medieval and early modern period, so its iconic attributes could be readily used to communicate the demonic nature of the witch's relationship with her familiar. Familiars were often described as dark in colour, symbolising their association with demons (Wilby 2000, p. 287; Anon 1579). Accounts of demonic trickery by familiars punctuated witchcraft trials and confessions in a way, enabling the use of pamphlet literature to warn readers against co-operation with the demonic, and incite a more determined rejection of superstition and false wonders (Anon 1589, B2r). A shared lexicon positioned the familiar on the margin of human and animal form, and at the linguistic intersection of true faith and false superstition in which the rejection of God was articulated in a highly religious language.

Such a visual and verbal language of the demonic, laden with darkness, transitional forms, trickery and temptation was widely disseminated. It was not, however, the product or preserve of the witch trials alone. The vocabulary that was used by and against those who were accused of witchcraft and consorting with familiars bore a marked resemblance to that which was used to denounce human commerce with other numinous beings, particularly fairies. Significant analysis has been undertaken here by Emma Wilby and others, who have identified the common ground that existed in early modern accounts of interaction with familiars and with fairies. Both fairy and familiar had access to a broad range of supernatural powers, which could be used to ill effect and good. A semantic imprecision in the use of words such as 'imp' or 'sprite' in both contexts testifies to the fluidity of the language and the permeability of the boundary. Such imprecision was reflected in the testimony provided by those accused of witchcraft, whose accounts of their familiars were heavily laden with imagery derived from the language of fairies and the wider supernatural (Wilby 2000; Anon 1566, A5v). Both fairies and familiars offered assistance to their human companions, and in both cases the acceptance of this offer acquired a contractual status and significance. The distinction between the familiar and the fairy was often not made by those most intimately associated with them, but by individuals seeking to label and categorise such creatures and their human interactions within the demands of a religious and cultural context.

Against this backdrop, the vehement assault on witches and their familiars in early modern England needs to be seen not as an isolated quirk, but as part of a broader attempt to suppress a syncretic popular culture in which aspects of religion, magic, and the broader supernatural had coalesced. The link between practitioners of popular medicine, healing, 'cunning folk' and witchcraft forms part of this nexus. Accusations of witchcraft levelled against cunning women demonised the remedies that they peddled as magic and superstition, illicit natural knowledge acquired by contact with forces beyond their control. Both fairies and familiars were reported to be able to assist in the location of lost property, but such use of magic and natural knowledge, even for benign purposes, was readily overlaid with demonic connotations. Heinrich Kramer and Jacob Sprenger, authors of the Malleus Maleficarum, counselled the reader against resort to 'wise women, by whom they are very frequently cured, and not by priests and exorcists. So experience shows that such cures are affected by the help of devils, which is unlawful to seek' (Institoris and Sprenger 1486). Even without systematic attempts to suppress such beliefs, cunning folk were viewed with heightened suspicion (Davies 2007, p. 4; Davies 2016, pp. 1-15). Alan Macfarlane identifies cunning folk as the primary target visitation articles that referred to 'sorcery, witchcraft, enchantments, incantations, charms, unlawful prayers, or invocations in Latin', and Owen Davies makes a persuasive case for seeking the same individuals as the initial focus of the 1563 'Act agaynst Conjuracons Inchantments and Witchecraftes' (Macfarlane 1970, pp. 67, 115; Davies 2007, p. 7). By claiming access to supernatural power, cunning folk left themselves open to accusations of witchcraft and demonic magic, particularly where such power appeared to derive from communication with spirits (Larner 2000, pp. 138-39). The demonization of cunning folk, fairies and imps was part of a broader effort to eliminate superstition, 'diabolical delusions' and the 'popish mist that had befogged the eyes of our poor people' (Harsnett 1603, pp. 135-36; Holland 1590, p. 8). 
But animal familiars were more than just a 'popish mist.' Anxieties about witches and witchcraft were articulated in different forms during the English witch trials, but that most 'different' creature, the familiar, emerges from the records as an important illustration of the diffuse origins of belief in magic, witchcraft, and the wider supernatural, and the role of animals and demons within it. The relationship between witch and familiar enables us to perceive both the distinctive nature of belief in England, and the diffusion and distillation of complex and often contradictory ideas in what at times appear to be the most mundane and ordinary moments. In those animals whose footprints can be seen in the English trials and literature, we can see the extent to which these animals acted as a pivotal point of intersection between learned and popular beliefs, demonology and traditional belief, attitudes to gender, and social and moral norms, and attitudes to human, animal, and interaction between the two. The pact between witch and familiar simultaneously shared the language of demonic pact, sabbath, and the surrender of the soul that permeated continental demonologies, and undermined it by locating that most feared of moments in the world of the domestic and the mundane. The feeding of animal familiars by witches presents evidence of the domestication of animals and the importance of animals as companions, while at the same time fuelling the persecution of witches on the basis that they shared that most precious and sacred fluid, human blood, in which inhered the soul, with creatures who were at best non-human, and at worst demonic. In the language used to describe familiars inhered both a traditional lexicon in which such creatures were recognised as agents of the supernatural, and a more novel vocabulary in which particular animals, were demonised. Familiars were hybrids, not totally animal, nor totally spirit, neither completely old, nor entirely novel, creating, and created by the narratives of witchcraft that emerged in England. This intersectionality should remind us that we have much to learn about the dimensions and dynamics of witch belief from the 'paltrie vermin, cats, mise, toads, and weasils.'

Funding: This research received no external funding.

Conflicts of Interest: The author declares no conflict of interest.

\section{References}

Allen, Andrew. 1979. Toads: The Biochemistry of the Witches' Cauldron. History Today 29: 265-68.

Amphlett Micklewright, Frederick Henry. 1947. A Note on the Witch-Familiar in Seventeenth Century England. Folklore 58: 285-87. [CrossRef]

Anon. 1566. The Examination of John Walsh: Before Maister Thomas Williams, Commissary to the Reuerend Father in God William Bishop of Excester, vpon Certayne Interrogatories Touchyng Wytchcrafte and Sorcerye, in the Presence of Diuers Ge[n]tlemen and others. The xxiii of August 1566. London: Iohn Awdely.

Anon. 1579. A Rehearsall Both Straung and True, of Hainous and Horrible Actes Committed by Elizabeth Stile: Alias Rockingham, Mother Dutten, Mother Deuell, Mother Margaret, fower notorious witches, apprehended at Winsore in the countie of Barks. and at Abbington Arraigned, Condemned, and Executed, on the 26 Daye of Februarie Laste Anno. 1579. London: [J. Kingston] for Edward White.

Anon. 1589. The Apprehension and Confession of Three Notorious Witches. Arreigned and by Iustice Condemned and Executed at Chelmes-Forde, in the Countye of Essex, the 5. Day of Iulye, Last Past. 1589: With the Manner of Their Diuelish Practices and Keeping of Thier Spirits, Whose Fourmes Are Heerein Truelye Proportioned. London: E. Allde.

Anon. 1664. A tryal of Witches at the Assizes Held at Bury St. Edmonds for the Count of Suffolk on the Tenth Day of March, 1664 [i.e 1665] before Sir Matthew Hale, Kt., then Lord Chief Baron of His Majesties Court of Exchequer/Taken by a Person then Attending the Court. Oxford (UK): Text Creation Partnership.

Bailey, Michael. 2003. Battling Demons: Witchcraft, Heresy, and Reform in the Late Middle Ages. University Park: Pennsylvania State University Press.

Bailey, Michael. 2006. The meanings of magic. Magic, Ritual, and Witchcraft 1: 1-23. [CrossRef]

Bailey, Michael. 2007. Magic and Superstition in Europe: A Concise History from Antiquity to the Present. Ranham: Rowman and Littlefield.

Behringer, Wolfgang. 1995. Weather, Hunger and Fear: Origins of the European Witch-Hunts in Climate, Society and Mentality. German History 13: 1-27. [CrossRef] 
Behringer, Wolfgang. 1997. Witchcraft Persecutions in Bavaria: Popular Magic, Religious Zealotry and Reason of State in Early Modern Europe. Cambridge: Cambridge University Press.

Bernard, Richard. 1629. A Guide to Grand-Iury Men: Diuided into Two Books: In the First, Is the Authors Best Aduice to Them What to doe, Before They Bring in a Billa vera in Cases of Witchcraft, with a Christian Direction to Such as Are too Much Giuen vpon Euery crosse to Thinke Themselues Bewitched. In the Second, is a Treatise Touching Witches Good and Bad, How They May bee knowne, Euicted, Condemned, with Many Particulars Tending Thereunto. By Rich. Bernard of Batcombe, 2nd ed. London: Felix Kingston for Edw. Blackmore.

Bodin, Jean. 1587. De la Démonomanie des Sorciers.: A Monseigneur M. Chrestofle de Thou, Cheualier, Seigneur de Coeli, Premier President en la Cour de Parlement, \& Conseiller du Roy en son priué Conseil, (Reueu, corrigé, \& augmenté d'une grand partie. ed.). Paris: Chez Iacques du-Puys, Libraire Iuré, à la Samaritaine.

Briggs, Robin. 2002. Witches and Neighbours: The Social and Cultural Context of European Witchcraft, 2nd ed. Oxford: Blackwell.

Broedel, Hans Peter. 2003. The Malleus Maleficarum and the Construction of Witchcraft. Manchester: Manchester University Press.

Bulliet, Richard W. 2005. Hunters, Herders, and Hamburgers: The Past and Future of Human-Animal Relationships. New York: Columbia University Press.

Clark, Stuart. 1997. Thinking with Demons: The Idea of Witchcraft in Early Modern Europe. Oxford: Oxford University Press.

Cohn, Norman. 2000. Europe's Inner Demons: The Demonization of Christians in Medieval Christendom. Chicago: University of Chicago Press.

Coxe, Roger, Henry Octavius, and Paris Matthew. 1841. Rogeri de Wendover Chronica, Sive Flores Historiarum, ed. H.O. Coxe. [With] Appendix, in qua Lectionum Varietas Additionesque Quibus Chronicon istud Ampliavit Matthæus Parisiensis. London: English Historical Society.

Creagor, Angela N. H., and William Chester Jordan. 2003. The Animal-Human boundary: Historical Perspectives. Rochester: University of Rochester Press.

Dalton, Michael. 1630. The Countrey Iustice: Containing the Practice of the Iustices of the Peace out of Their Sessions: Gathered for the Better Helpe of Such Iustices of Peace as Haue not Beene Much Conuersant in the Studie of the Lawes of this Realme. Now the Fourth Time Published, and Reuised, Corrected, and Inlarged, the Additions Being Thus Marked, [Pointing Hand] by Michael Dalton of Lincolnes Inne, Esquire. Early English books online. Available online: http://www.getfilehost.com/get-file.pdf?q=the_countrey_iustice_containing_the_practice_ of_the_iustices_of_the_peace_out_of_their_sessions_by_michael_dalton_1630 (accessed on 25 February 2019).

Davies, Owen. 2007. Popular Magic: Cunning-Folk in English History. London: Hambledon Continuum.

Davies, Owen. 2016. Fairies and the Devil in early modern England. The Seventeenth Century 31: 1-15.

Edwards, Kathryn A. 2002. Werewolves, Witches, and Wandering Spirits: Traditional Belief and Folklore in Early Modern Europe. Kirksville: Truman State University Press.

Ewen, L'Estrange Charles. 1933. Witchcraft and Demonianism: A Concise Account Derived from Sworn Depositions and Confessions Obtained in the Courts of England and Wales. London: Heath Cranton.

Gifford, George. 1593. A Dialogue Concerning Witches and Witchcraftes: In Which is Laide Open How Craftely the Diuell Deceiueth not Onely the Witches but Many Other and so Leadeth Them Awrie into Many Great Errours. By George Giffard Minister of Gods Word in Maldon. (Early English books online). Oxford (UK) : Text Creation Partnership.

Guazzo, Francesco, and Montague Summers. 1988. Compendium maleficarum: The Montague Summers Edition. New York: Dover.

Harsnett, Samuel. 1603. A Declaration of Egregious Popish Impostures: To With-Draw the Harts of her Maiesties Subiects from Their Allegeance, and from the Truth of Christian Religion Professed in England, Vnder the Pretence of Casting out Deuils. Practised by Edmunds, Alias Weston a Iesuit, and Diuers Romish Priestes His Wicked Associates. Where-vnto Are Annexed the Copies of the Confessions, and Examinations of the Parties Themselues, Which Were Pretended to be Possessed, and Dispossessed, Taken vpon oath Before Her Maiesties Commissioners, for Causes Ecclesiasticall. (Early English books online). London: Iames Roberts, dwelling in Barbican.

Herzig, Tamar. 2010. Flies, Heretics, and the Gendering of Witchcraft. Magic Ritual and Witchcraft 5: 51-80. [CrossRef] 
Holland, Henry. 1590. A Treatise Against Witchcraft: Or A Dialogue, Wherein the Greatest Doubts Concerning that Sinne, Are Briefly Answered: A Sathanicall Operation in the Witchcraft of All Times is Truly Prooued: The Moste Precious Preseruatiues against Such Euils Are Shewed: Very Needful to be Knowen of All Men, but Chiefly of the Masters and Fathers of Families, That They May Learn the Best Meanes to Purge Their Houses of All Vnclean Spirits, and Wisely to Auoide the Dreadfull Impieties and Greate Daungers Which Come by Such abhominations. Hereunto is also Added a Short Discourse, Containing the Most Certen Meanes Ordained of God, to Discouer, Expell, and to Confound All the Sathanicall Inuentions of Witchcraft and Sorcerie. Cambridge: Iohn Legatt.

Hopkins, Matthew. 1647. The Discovery of Witches: In Answer to Severall Queries, Lately Delivered to the Judges of Assizes for the County of Norfolk. And Now published By Matthew Hopkins, Witch Finder. For the Benefit of the Whole Kingdome. London: Richard Royston.

Institoris, Heinrich, and Jacob Sprenger. 1486. Malleus Maleficarum. Metz: [Caspar Hochfeder].

Kean, Hilda. 2012. Challenges for Historians Writing Animal-Human History: What is Really Enough? Anthrozoos 25: 57-72. [CrossRef]

Kieckhefer, Richard. 1976. European Witch Trials: Their Foundations in Popular and Learned Culture, 1300-1500. London: Routledge and Paul.

Kieckhefer, Richard. 1996. The Specific Rationality of Medieval Magic. American Historical Review 99: 813-36. [CrossRef]

Kittredge, George Lyman. 1929. Witchcraft in Old and New England. Cambridge: Harvard University Press.

Klaits, Joseph. 1985. Servants of Satan: The Age of the Witch Hunts. Bloomington: Indiana University Press.

Larner, Christina. 2000. Enemies of God: The Witch-Hunt in Scotland. Edinburgh: John Donald.

Lüthi, Max. 1976. Once Upon a Time: On the Nature of Fairy Tales. Bloomington: Indiana University Press.

Macfarlane, Alan. 1970. Witchcraft in Tudor and Stuart England: A Regional and Comparative Study. London: Routledge \& Kegan Paul.

Magnus, Olaus. 1555. Historia de Gentibus Septentrionalibus. Rome: [apvd Ioannem Mariam de Viottis Parmensem].

Monter, William. 1997. Toads and Eucharists: The Male Witches of Normandy 1564-1600. French Historical Review 20: 563-95. [CrossRef]

Montesano, Marina. 2018. Classical Culture and Witchcraft in Medieval and Renaissance Italy. Basingstoke: Palgrave Macmillan. Murray, Margaret Alice. 1970. The God of the Witches. (Galaxy Book; GB332). London: New York: Oxford University Press.

Notestein, Wallace. 2003. A History of Witchcraft in England from 1558 to 1718. Whitefish Montana: Kessinger.

Perkins, William. 1608. A Discourse of the Damned Art of Witchcraft. Cambrirdge: C. Legge.

Petzoldt, Leander. 1990. Sagen aus der Steiermark. München: Diederichs.

Phillips, John. 1566. The Examination and Confession of Certaine Wytches at Chensforde in the Countie of Essex, before the Quenes Majesties Judges, the xxvi Daye of July. ANNO. 1566 at the Assise Holden There as Then, and One of Them Put to Death for the Same Offence, as Their Exclamation Declareth More at Large. London: Willyam Powell for Wyllyam Pickeringe.

Pico della Mirandola, Giovanni, and Alfredo Perifano. 2007. La Sorcière: Dialogue en Trois Livres sur la Tromperie des Démons = Dialogus in tres Libros Divisus: Titulus est Strix, sive de Ludificatione Daemonum, 1523. (De diversis artibus; t. 81). Turnhout: Brepols.

Purkiss, Dianne. 2001. Sounds of Silence: Fairies and Incest in Scottish Witchcraft Stories. In Languages of Witchcraft: Narrative, Ideology and Meaning in Early Modern Culture. Edited by Stuart Clark. Basinsgtoke: Macmillan.

Raine, James. 1861. Depositions from the Castle of York Relating to Offences Committed in the Northern Counties in the Seventeenth Century. Durham: Surtees Society.

Russell, Jeffrey Burton. 1972. Witchcraft in the Middle Ages. Ithaca and London: Cornell University Press.

Sax, Boria. 2009. The Magic of Animals: English Witch Trials in the Perspective of Folklore. Anthrozoös 22: 317-32. [CrossRef]

Serpell, James A. 2002. Guardian spirits or demonic pets: The concept of the witch's familiar in early modern England, 1530-1712. In The Animal-Human Boundary: Historical Perspectives. Edited by Angela N. H. Creager, William C. Jordan and Shelby Cullom. Rochester: University of Rochester Press, pp. 157-190.

Shakespeare, William, and George Hunter. 2015. Macbeth. London: Penguin Classics.

Shakespeare, William, Harold Oliver, and Katherine Duncan-Jones. 2015. As You Like It. London: Penguin Classics. Sharpe, James. 1997. Instruments of Darkness: Witchcraft in Early Modern England. Philadelphia: University of Pennsylvania Press. 
Stearne, John. 1648. A Confirmation and Discovery of Witchcraft: Containing These Severall Particulars: That There Are Witches ... Together with the Confessions of Many of Those Executed Since May 1645. London: William Wilson. Stephens, Walter. 2016. Skepticism, Empiricism, and Proof in Gianfrancesco Pico della Mirandola's Strix. Magic, Ritual, and Witchcraft 11: 6-29. [CrossRef]

Thomas, Keith. 1971. Religion and the Decline of Magic. New York: Scribner.

Thomas, Keith. 1983. Man and The Natural World: Changing Attitudes in England 1500-1800. London: Allen Lane. Topsell, Edward. 1607. The Historie of Foure-Footed Beastes. London: William Jaggard.

W. W. 1582. A True and Iust Recorde, of the Information, Examination and Confession of All the Witches, Taken at S. Ofes in the Countie of Essex: Whereof Some Were Executed, and Other Some Entreated According to the Determination of Lawe. Wherein All Men May See What a Pestilent People Witches Are, and How Vnworthy to Lyue in a Christian Commonwealth. Written Orderly, as the Cases Were Tryed by Euidence, by W. W.. London: Thomas Dawson.

Weiss, Harry B. 1930. Insects and Witchcraft. Journal of the New York Entomological Society 38: 127-33.

Wilby, Emma. 2000. The Witch's Familiar and the Fairy in Early Modern England and Scotland. Folklore 111: 283-305. [CrossRef]

William of Malmesbury, and Stubbs William. 1887. Willelmi Malmesbiriensis Monachi De Gestis Regum Anglorum libri Quinque; Historiae Novellae Libri Tres. (Rerum Britannicarum medii aevi scriptores; no. 90). London: Nabu Press.

Wright, Thomas. 1833. A Contemporary Narrative of the Proceedings against Dame Alice Kyteler: Prosecuted for Sorcery in 1324, By Richard de Ledrede, Bishop of Ossory. London: Camden Society.

Wright, Pip, and Joy Wright. 2005. Witches in and around Suffolk. Stowmarket: Paw-print Publishing.

(C) 2019 by the author. Licensee MDPI, Basel, Switzerland. This article is an open access article distributed under the terms and conditions of the Creative Commons Attribution (CC BY) license (http:/ / creativecommons.org/licenses/by/4.0/). 
Article

\title{
Treasure Hunt-Roman Inquisition and Magical Practices Ad Inveniendos Thesauros in Southern Tuscany
}

\author{
Vincenzo Tedesco \\ Scuola Superiore di Studi Storici, University of the Republic of San Marino, Salita alla Rocca, 44, \\ 47890 San Marino (RSM), San Marino; vincenzotedesco90@libero.it
}

Received: 5 June 2019; Accepted: 18 July 2019; Published: 22 July 2019

\begin{abstract}
Resorting to the supernatural to find something lost is a practice that can be observed over a very large range of times and places. With the affirmation of Christianity, these kinds of habits and beliefs were considered superstitious by the Church. During the early modern era, the institution appointed to control the integrity of the faithful in the Italian peninsula was the Supreme Sacred Congregation of the Roman and Universal Inquisition, which had a significant number of local tribunals spread over the territory. This essay aims to study the diffusion of the practice of finding treasures by using magical items and rituals in the area under the jurisdiction of the Sienese tribunal of the Holy Office (approximately the entire southern Tuscany), whose trial sources are preserved in the Archive of the Congregation for the Doctrine of the Faith (Vatican City). The research, based on around seventy individual cases, shows an interesting belief from a historical-anthropological point of view, namely: although in most cases people were looking for everyday objects that they had lost, sometimes, they used the same rituals to search for ancient treasures that they heard were buried or hidden in a particular place (church, field, or cellar), with the presence of guardians like spirits or demons, that had to be driven away with a prayer or an exorcism before taking possession of the treasure.
\end{abstract}

Keywords: treasure hunting; Inquisition; Holy Office; heresy; sorcery; magic; divination; devil; Early Modern History

\section{In Search of Lost Riches}

In past centuries, the use of magic to find objects of various kinds was very widespread. When something valuable happened to be lost because of inattention or theft, resorting to the help of supernatural entities that were believed to be aware of the exact place where the good was hidden, was not uncommon.

The same mechanism could also be used to look for something important that was hidden underground - many legends floated around about the existence of riches scattered in the countryside and in the cities, fortunes buried to be preserved from theft and raids, or fantastic treasures of an ambiguous or unknown form. Books circulated on this topic, like the manuscript entitled Note about the Hidden Treasures in Several Italian Cities (Nota de thesori nascosti in diverse città d'Italia), that appeared in a Sienese trial of 1612 , within which were described, city by city, all of the treasures that were in the Italian peninsula, including one consisting of two precious volumes, "one consecrated, the other of experience" ("uno consecrato, et l'altro di esperienza"), which was found behind a stone inside the house of Cecco d'Ascoli, 
a famous intellectual who lived between the 13th and 14th centuries, and-not surprisingly-was a well-known astrologist (condemned to the stake in 1327) ${ }^{1}$.

To find these hidden treasures, it was usual to resort to spells that, in the trial sources, were called "ad inveniendos thesauros", or, more briefly, "ad thesauros". It is a phenomenon that had a wide geographical spread, especially in the early modern age, as can be seen, for example, from the fact that it appears in the still useful Encyclopedia of Witchcraft, edited by Golden (2006), and in areas far away from each other, such as in Peru and the entire Spanish America, in Aragon, in Hungary and Southeastern Europe, in Russia, and in several Italian cities like Modena and Siena ${ }^{2}$; other studies have shown the presence of this phenomenon in various countries of Northern Europe, like England ${ }^{3}$ and Sweden ${ }^{4}$.

Many historians, during their research, have bumped into sources that mention these practices, but the most complete and detailed study on the subject turns out to be the one of Johannes Dillinger, entitled Magical Treasure Hunting in Europe and North America. A History. In this book, the author analysed several aspects of the "magical" treasure hunts in the long period of time between the Middle Ages and the Contemporary world, observing how most cases took place in the early modern period, decreasing significantly during the 18th century; at the same time, Dillinger focused his attention on the development of the jurisprudence on the subject (which forbade the use of magic in research, but did not identify it exactly as witchcraft), on the constant belief that the treasures were kept by supernatural entities who played the role of guardians (who had to be driven away through the use of exorcisms), on the invocation of demons and saints to know the exact place to dig, which could also be found with the use of specific objects ${ }^{5}$. I will consider some of these topics later in this paper.

In the Italian peninsula, these practices were widespread; suffice it to say that "in many parts of Central Europe, the common people talked about foreigners speaking a Romance language who had come to search for hidden treasures or gold and silver mines", and these mysterious hunters were often the Venetians, who, in the folk legends were "skilled magicians" with the ability to "find gold and treasure where the locals could not" ${ }^{\prime 6}$. There are many examples, in the secondary literature, of the numerous treasure hunts that happened around the Italian cities during the early modern age. For instance, the priest Guglielmo Campana of Modena, in 1513-1514, was called to Bologna to help the aristocrat Bernardino Marescotti to look for a treasure in his possession ${ }^{7}$; in the area of Naples Domenico De Cotiis, Ettore Cangiano and other people participated in various treasure hunts in the 1680 s of the 16th century ${ }^{8}$; in Sicily, in the town of Nicolosi at the bottom of the volcano of Mount Etna, after an eruption and an earthquake in 1633, it seemed that many people started searching for treasures in the rubble, drawing the attention of the Spanish Inquisition ${ }^{9}$. In all of these cases, there was a use of magic that started a scandal and attracted the suspicion of the Catholic authorities, which resorted to the instrument of the ecclesiastical courts in order to punish those who, in their eyes, were guilty of crimes against the faith.

1 Vatican City, Archivum Congregationis pro Doctrina Fidei (from now on ACDF), Archivum Inquisitionis Senensis (from now on Siena), Processi, vol. 25, fo. 201r-v.

(Golden 2006, ad vocem).

Cf. (Macfarlane 1999, passim; Thomas 1991, particularly, pp. 279-82)

(Lindow 1982).

(Dillinger 2012).

(Dillinger 2012, pp. 79-84). Dillinger linked the folk beliefs on the Venetians with the groups of traders who travelled around the Middle Europe in search of raw materials for the glass making: actually, for a foreign observer, these people were really able to turn worthless stuffs found in the ground into "treasures", namely the famous and valuable glassware typical of the Venetian production.

(Duni 1999, pp. 244-8).

(Sallmann 1986, particularly pp. 17-20, 164-70).

(Alessi 1834, pp. 106-7): “alli 21 di febraro dell'anno 1633 infierì il fuoco dell’Etna e pel subitaneo terremoto crollò [ ... ] Nicolosi [ ... ] mentre persone malefiche cavavano ascosti tesori, adoprando inique pratiche superstiziose. Né solamente ciò credette la plebe, ma si fè severa inquisizione di coloro che intervennero all'abominevole ragunanza, e castigo dalla Corte chiesiastica ne riportarono". 
Actually, most of the sources on the ad thesauros spells in Italy consisted of trials of the Inquisition, the institution specially appointed by the Apostolic See to control the religious dissent. In the states of the North and the Centre of the peninsula, were a number of local courts, which were attached directly to the Congregation of the Holy Office, a department created by Paolo III Farnese in 1542, while in the islands of Sicily and Sardinia, the inquisitors were nominated by the kings of Spain, and in the wide Kingdom of Naples, a mixed system operated that was structured around the diocesan ordinaries with territorial jurisdiction, who, if necessary, cooperated with the friars sent by Rome ${ }^{10}$.

Unfortunately, despite some works that face the topic through some cases studies ${ }^{11}$, extensive and detailed research is not yet available for a large number of documents that examine, in depth, the relationship between the Holy Office and these spells. What was the position of the Roman Church on the matter? How did the inquisitors judge these cases? What was the perspective of those who were under investigation? The ambition of this paper is to try to give answers to these questions-without any claim of completeness-and to contribute to the study of ad thesauros spells in the Catholic area.

The interest of the Roman Church towards the repression of beliefs defined as "superstitious" emerged in an increasingly clear manner during the 16th century, and among those, there was the idea that rural areas and cities were full of hidden treasures waiting to be found by those who had the ability to find them through divinatory techniques ${ }^{12}$. It was first shown by the Libellus that Paolo Giustiniani and Pietro Querini were sent to Leo X in 1513, and that the two Camaldolese Hermits warned the Pope of the danger posed by these customs, and secondly, by the bull Coeli et terrae of Sixtus V (1586), who forbade astrology and the divinatory practices.

It is important to clarify that the theologians set the magical treasure hunting in the context of divination, probably because they thought that magicians used their power to predict where in the future the riches would be found, and not in which place they were.

Furthermore, the ability to foretell something unknowable to the humans was linked to the invocation (explicit or implicit) of the devil, who was believed to be aware of future things ${ }^{13}$. This concept is well clarified in a page of one of the most widespread inquisitorial manuals, the Sacro arsenale, written by the Dominican friar Eliseo Masini, who was himself an inquisitor, "is forbidden for magicians and astrologists to search where the treasures are, because the magicians cannot know this, unless they spy on the devil: and the astrologists for the same purpose make use of his work"14.

Lastly, it should be noted that treasure hunting sometimes implied the use of res sacrae, such as surplices, stoles, hosts for the Eucharist, and holy water to bless the objects used for the rituals; this was considered a serious crime, especially as many people of the clergy were involved.

\section{Magical Researches in Southern Tuscany}

It has been said that in the Italian peninsula, there were many ad thesauros spells performed, and Tuscany is no exception. Amidst the numerous evidence of this, it is useful to report the case of Jacobo Fracesso and Giuseppe di Mariano, who "had attempted to locate hidden treasure" in Orbetello in $1640^{15}$, or the one of Cul di Paiolo, a place near Arezzo, where a "French magician" organized

10 The bibliography on the history of the Inquisition in the Italian peninsula is particularly rich, and has expanded considerably in recent decades. As it is not possible to provide a specific overview in just one footnote, we refer to the texts that are most significant for this paper (Tedeschi 1991; Bethencourt 2011; Prosperi 2009; Del Col 2009; Black 2009; Prosperi et al. 2010; Mayer 2013; Mayer 2014; Aron-Beller and Black 2018).

11 Cf. (Duni 1999; Sallmann 1986).

12 (Lavenia 2001; Lavenia 2013; Valente 2015).

13 The devil's knowledge of the future is a concept already present in Augustine of Hippo (cf. Limonta 2017); on the invocation of demons (and saints) in treasure hunting, see also (Dillinger 2012, pp. 62-3).

14 "Non è lecito né da i Maghi, né da gli Astrologhi ricercare, ove siano tesori, perché non possono ciò sapere i Maghi, se non spiano dal Demonio: e gli Astrologhi a tal effetto si servono pure dell'opra di lui" (Masini 1639, p. 354).

15 The trial took place ten years after the fact in the court of Siena, and was studied recently by Louise Nyholm Kallestrup, who summarized it as follows: "Guiseppe had known of a certain magical practice, which involved the two men going out under cover of the night with a cane made of consecrated olive wood. On this cane were carved some mysterious letters, and the 
an excavation to seek a treasure on the property of the Marquis Bartolomeo Montauti, in which the same Bishop of Arezzo, Niccolò Marchetti (1691-1704), commanded a priest to exorcise the dig ${ }^{16}$.

Many of these situations can be found among the trials of the court of the Holy Office based in Siena, which extended its jurisdiction to approximately all of Southern Tuscany ${ }^{17}$. The purpose of the following pages is to describe these sources (mostly unpublished), giving an analysis of the beliefs, the status of the people involved, and the attitude of the Roman inquisition in front of these circumstances. Doing this, we preferred to give priority to around seventy trials, in which the only charge was the ad thesauros spell, because the judicial procedure is clearer and not tainted with other crimes; but it must be said that there are dozens of trials in which the spell in question is mixed with other types of offence, given that the magicians usually practiced a lot of different charms ${ }^{18}$.

The most common use of divinatory arts was aimed at searching for objects that were lost or stolen. In Siena, it was already mentioned in the 15th century in the Sermons of the Franciscan friar Bernardino da Siena, who reported an event occurred in Lucca in 1417-a man had lost a large sum of money and asked an old woman to help him find it; during the night, she invoked a devil, who revealed that the money had been "lost by accident in a pigsty", and that there was still some there (the rest was eaten by pigs) ${ }^{19}$.

Another example is given by a peasant woman named Marta, who, in 1592, admitted that finding lost objects was actually her job, "when someone lost something they came to me to let me look [into a carafe] [ ... ]. [And I have done it] for necessity, because those who came paid me one giulio (currency of the Grand Duchy of Tuscany) or two" ${ }^{\prime 20}$. Oscar Di Simplicio, leading expert in the study of witchcraft in early modern Siena, has observed that the "experiment of the carafe" was statistically the most widespread spell in the Sienese state ${ }^{21}$. It worked more or less in the following way: a jug had to be filled with water (better if blessed), and a virgin girl had to look onto the surface; she, being pure, could see reflected on the water the exact place where the lost object was. Frequently, there were different prayers recited during the ritual, and some people held blessed candles.

Some cases show these customs particularly well. In 1679, a man named Giuseppe Paganucci reported in Piombino a mid-aged woman, Violante Buoncompagni, because she had heard about the existence of a "hideout" in a house, and she practiced (with other people) the ritual of the carafe to find where it was; moreover, she "had two young women kneeling close to this jug and it seems to me that the priest Mariani told me that each of them had a candle burning in their hands, and in this way everyone could see the hideout inside the jug [ . . ] ; meanwhile, Violante muttered to herself some words, which were reputed to be prayers, and at the same time the two girls saw in the jug a frightening figure; therefore the work failed"22. This experiment could be also used to find treasures, as follows: three years later, in Pitigliano, four people reported themselves to the vicar of the Holy Office, because they tried to find lost riches after Riccardo Borghi had heard that "in some

idea was that the cane would lead the two men to the right place to dig for treasure. Although Jacobo and Guiseppe believed that they had found the right spot and had started digging, they never located the treasure" (Kallestrup 2015, p. 111).

16 At the end of the excavation, it appeared to just be a stone crucified Christ, and the foreigner magician left with angry, while the priest was put before a judge by the Inquisition, and was condemned to the galley for many years (nothing seems happened to the bishop and the marquis). See (Cristelli 2008).

17 (Di Simplicio 2010).

18 The documents of the Sienese Holy Office, which worked from the 1560s until its suppression in 1782, can be consulted since 1998 in the ACDF, where more than 200 volumes were moved from Siena at the beginning of the 20th century. See (Cifres 2000 , p. 83).

19 (Montesano 2018, p. 153).

20 "Quando alcuno aveva perso qualcosa correvano da me acciò facesse mirare [nella caraffa] [ ... ]. [E l'ho fatto] per bisogno, perché quelli che venivano chi mi dava un giulio, chi due" (Di Simplicio 2005, p. 75)

21 (Di Simplicio 2005, p. 74)

22 ACDF, Siena, Denunce 1676-1681, fo. 759r: "faceva stare in contro a questa Caraffa due fanciulle in ginochioni e mi parve mi dicesse il Prete Mariani che ciaschuna di esse havesse una candela accesa ne le mani, et in tal modo tutte vedessero dentro la Caraffa il Repostiglio [ ... ] fra tanto Violante mormorava fra se alcune parole, ch'eran giudicate orazioni, e nel istesso tempo le due fanciulle videro dentro la Caraffa una figura spaventosa; non riuscì però l'opera". 
places were hidden large amounts of money since the war of Castro"23; one of those who did the experiment, Francesca di Andrea, said that she saw four different places in the water inside the jug where there were hidden money, silver, and gold ${ }^{24}$. Sometimes, the rituals were considered more serious by the inquisitorial judge; in 1672, in fact, a ritual organized by a priest named Giovanni Turini and two other men, Antonio Marini and Fausto Tagliabossi, who let virgin boys and girls look into a glass ampoule filled by blessed water, with a burning candle aside, invoking the Holy Spirit to find out where a treasure was, led to three sentences, of which two led to abjure de levi, and one, for the priest—who also used surplice and stole during the ritual—to abjure de vehementi (after being tortured during the trial) $)^{25}$. It should be noted that the invocation of the Holy Spirit has been interpreted by the judge as an invocation of the devil; the difference can be explained with the position of the Church, with regard to the demonology, or maybe with the explicit passage of the abovementioned Masini's Sacro arsenale.

Anyway, the most used object for finding treasures that were hidden underground was the "divining rod" (or mosaical rod), which was a forked branch or a couple of sticks commonly used for rhabdomancy. This practice, originally utilized to find mineral veins or water, could also be applied for treasures. The idea behind this custom was that "some kind of emanation of minerals, metals, water-or treasure-rises out of the Earth to the surface and somehow attracts the dowsing rod" 26 . The difference between a common rod and another one that was used by magicians was that the latter had signs, crosses, or short formulas engraved on it (often blessings, extracts from prayers or magical words), reputed to increase the power of the object.

The Sienese court of the Holy Office faced a lot of cases of this kind, and through them, we can recreate all of the phases, from the making to the use of these staffs. For example, the Franciscan friar Filippo da Petroio, in 1595, confessed a "secret" handed down, for make a divining rod. On a particular day, like Sunday, at sunrise, one needed to go to an olive grove and recite on bended knee the whole John 1:1, before cutting two forked branches from a tree, and, upon them, one had to engrave the word "Adonai" (which means "God" in Jewish) and to draw a rising sun. After that, one could go where the treasure was thought to be, and see where the sticks brought them; at the same time, to increase their effect, it was recommended to recite over and over again a verse of the Psalm 51, "ecce enim veritatem dilexisti: incerta et occulta sapientiae tuae manifestasti mihi" ${ }^{27}$. The mixing of the sacred and profane is clear, and the ritual also entailed a good knowledge of Latin, which was used only by cultured people.

The treasures could be literally anywhere, not just in the rural areas, but also inside cities, in the richly decorated Renaissance houses of the Sienese patricians. In fact, the case of the noblewoman Agnese Tinelli, who was denounced by another woman in 1678, because in front of her, she used three rods to find a hidden treasure in her own house, which was certainly not isolated ${ }^{28}$.

Also, the branches of the olive tree were the principal kind of wood that could be used for making a divining rod, but they were not the only one. In 1680, for example, the canon Vieri da Grosseto used

23 "In alcuni luoghi ci erano nascosti dalla guerra di Castro buone somme di denari" (ACDF, Siena, Denunce 1682-1688, fo. 160r). The war of Castro was a conflict between the Papal States and the Farnese dukes of Parma in the 1640s, which ended with the destruction of the city of Castro in 1649 by the pope Innocent X (cf. De Maria 1898).

24 ACDF, Siena, Denunce 1682-1688, fo. 158v-159r.

25 ACDF, Siena, Processi, vol. 48, fo. 497r-600v (sentences and abjurations at fo. 544r-550v); or this trial see also the letters in (Di Simplicio 2009, pp. 377, 380-1,385).

26 For an in-depth analysis of the use of the divining rod, see ((Dillinger 2012, pp. 95-105 (cit. p. 99))). This method was well-known even by intellectuals and scholars of the Renaissance, namely: Georg Agricola, expert of mineralogy and author of De re metallica (1556), knew of the use of the rod, but did not recommend it (Dillinger 2012, p. 104), and Giambattista Della Porta definitely criticized it (Eamon 1994, p. 208), but the sources show that these voices remained unheard for centuries.

27 ACDF, Siena, Processi, vol. 7, fo. 858r-899v; Cause 1595, fo. 150r-187v. The friar was imprisoned and tortured during the trial, and, in July 1595, was condemned to various penances (Processi, vol. 7, fo. 897r-898v). The recitation of that particular verse of Psalm 51 was certainly common practice, because don Guglielmo Campana said the same words in Bologna in 1513-5114 (cf. Duni 1999, p. 247), as well as Gabriele Nasazzi, who did it in Pisa in 1612 (ACDF, Siena, Processi, vol. 25, fo. 374r).

28 ACDF, Siena, Denunce 1676-1681, fo. 394r-v. 
a reed leant against his chest to search a treasure that, according to a legend, was buried in a vineyard near Roccastrada ${ }^{29}$. In 1729, instead, Francesco Martinelli used an elm branch, because he had heard that "they had the virtue of finding treasures or hidden things, or veins of water, or metals", but, despite the attempt, nothing was found ${ }^{30}$.

The experiment of the divining rod was really widespread, but the different attempts that people made in the early modern age to find hidden treasure show a great variety of items used in disparate rituals. For instance, in 1676, a friar used a blessed candle and the bones of the dead, in addition to the $\operatorname{rod}^{31}$; in 1723, the patrician Francesco Maria Bartoli abjured de vehementi, because he had watered five broad beans with blessed water, planted in a death's head in order to do a ritual with the pods ${ }^{32}$. The use of bones is not surprising, because it was a common belief that the dead, as with the devils, were aware of many of the things of the world of the living; for the same reason, they could also help to find treasure, showing themselves in dreams or in a supernatural vision; in 1682, in fact, a woman said that in the cathedral of Pitigliano, one of her ancestors appeared to tell her the location of a treasure in the church, and the way to recover $\mathrm{it}^{33}$.

One of the most complex objects was the "geomantic ball" ("palla geomantica"), which was a specific type of magnet hanging by a thread, the use of which was similar to the rod-when the magnet tilted in one direction, its angle showed where the treasure was ${ }^{34}$. An important historical source clearly shows the process of making this particular ball—in a 1722 trial, Niccolò Tondi handed the Sienese inquisitor a sheet of paper entitled Geomantic ball. True and real way to make the geomantic ball which the Eastern Indians use to find gold and silver mines and other metals, it also indicates where are hideouts and treasures (Palla Geomantica. Vero, e real modo di fabbricare la palla geomantica con la quale gli Indiani Orientali se ne servano per trovare le miniere dell'Oro, e del Argento, e altri metalli, dà segno ancora dove sono ripostigli o Tesori). The procedure was particularly articulate, as follows: a hazelnut had to be pierced with an iron awl and had to be empty and successively filled-at specific moments during the week-with tin, copper, lead, silver, iron filings, quicksilver, and a piece of magnet; after that, a thread had to be inserted into the hole of the hazelnut, and the whole artefact had to be covered with wax ${ }^{35}$. Obviously, the geomantic ball could be made in different ways, according to the different contexts.

In southern Tuscany, the geomantic ball was used particularly in some cases during the 18th century. In the already mentioned 1722 trial, for example, it was written that, according to a legend, the founder of a monastery in Abbadia San Salvatore along with some monks had hidden important books and silver inside the building so as to save them during the wars, and in 1722, some Fathers endeavored to find them. Firstly, a French hermit tried the experiment of using the divining rod, and secondly - because the first attempt had not worked - the Florentine, Father Galgano Bartolini, used the geomantic ball, which seemed to indicate a place in an underground room; the abbot of the monastery, Orazio Angelini, exorcised the place "having a doubt that there could be Guards or Illusions" ("dubitando che vi potessero essere Guardie o Illusioni"), and after an excavation nothing was found ${ }^{36}$.

The statement of Angelini takes into account another important aspect of the treasure hunting-it was a common opinion that the hidden riches were guarded by supernatural entities, which, in the context of Christian religiosity, were usually devils. It is hard to find terms like "spirit" or "ghost"

\footnotetext{
Ibidem, fo. 859 r-860r.

"Avevo sentito dire che avessero la virtù di far trovare tesori, o cose nascoste, o vene d'acqua, o di metalli di qualsivoglia sorte" [ACDF, Siena, Cause 1729 (A), fo. 195r-196v].

ACDF, Siena, Denunce 1676-1681, fo. 97r-98v.

ACDF, Siena, Cause 1723 (A), fo. 423r-426r.

ACDF, Siena, Denunce 1682-1688, fo. 225r-228r

Cf. (Amoretti 1808, pp. 25-8).

ACDF, Siena, Cause 1722, fo. 172r-v.

ACDF, Siena, Cause 1722, fo. $143 \mathrm{r}-187 \mathrm{v}$ (cit. fo. 158v). The trial ended with the severe admonitions of those who had taken part in the spell experiments.
} 
as guardians of treasure in the Italian sources, and, in any case, the meaning almost always leads to "demon"; just in some cases, is possible to find the "soul" (of a dead man). For Johannes Dillinger, there are some reasons behind this belief, as follows: "Firstly, the subterranean realm was often seen as the realm of demons. [ ... ] Secondly, in the Christian ethics of Old Europe, money and wealth were at best ambivalent. Even money acquired by perfectly legal and moral means could be a diabolic temptation. [... ] Thirdly, the power of the demons over treasure troves was simply another element of their huge magical potency"37. The role of these beings was to keep the treasure hidden and to interpose themselves between the gold and the hunters, who instead had the task of drive them out, according to the Christian rite of the exorcism. In 1729, for instance, the patrician Pietro Paolo Martini abjured de levi for instigating a priest to do exorcisms (with surplice, stole, holy water, blessed candles, and a blessed spike) many times in many places, in order to drive away the guardians and take out the treasures ${ }^{38}$. There were even books with instructions on what to do in these circumstances, which circulated among the people, as is shown in another case of the 1720s, in which the libellus was still attached to the file in two copies, and is entitled Modus exorcizandi Thesaurum a spiritu maligno conservatum et obsessum ${ }^{39}$.

The methods of transmission of these kind of beliefs is another important subject. Although there was certainly an oral diffusion among the folk about the way to find lost objects or hidden treasures, it is also true that the "secrets" to accurately practice these rituals were often written on brief sheets of paper or longer manuscripts that were widespread. These texts were obviously forbidden by the Church, a factor that increased their fascination for those who were not only trying to use the mysterious power of magic, but could also handle a book that was itself prohibited by the Ecclesiastical authorities.

In 1595, the already mentioned Fra' Filippo da Petroio learned his magical secrets from a book that he had found in a hole ${ }^{40}$; in 1610, another Franciscan friar, Marco da San Casciano, brought to the Sienese inquisitor a manuscript that was hard to read, "full of unknown characters and alphabetical letters, and numbers", which was found among the ones belonging to the brother Bernardino da Ventimiglia $^{41}$; in 1618, Sisto Sisti da Piancastagnaio abjured de vehementi, because he had tried a lot of different experiments to find treasures that he had read about in a book ${ }^{42}$; in 1684, Domenico di Antonio da Castelfranco di Valdarno stole a book from a Jew and went to Asciano to find a treasure, following the indications that he had read ${ }^{43}$; and in 1723, the "secrets" appeared in some sheets of paper used by Giovanni Maria Sardini ${ }^{44}$. These examples could continue.

Sometimes, a real business was created around treasure hunting, because the knowledge of the methods to have riches out of nothing was considered valuable by those who believed in its authenticity. For instance, in 1637, Domenico di Francesco da Montevitozzo, a farmer that could not read, paid three scudi to a Jew to buy a book with the meaningful title of Lucidario di Abano ${ }^{45}$, to search for buried treasures near his small town ${ }^{46}$, and in 1721, Giuseppe Antonio Castellucci, in a tavern in Ronciglione, paid half a grosso to a hermit who dictated to him a True secret to take out treasures guarded by souls or demons (Reale segreto per cavare tesori guardati da anime o demoni) ${ }^{47}$. Of course, this trade left place for speculation or frauds. It is clearly shown by the statements of the Sienese Ranuccio Venturi during the 1589 trial against the shoemaker Giulio di Francesco da Carrara, that Ranuccio told the inquisitor that,

\footnotetext{
(Dillinger 2012, p. 62).

ACDF, Siena, Cause 1729 (A), fo. 393r-411v.

ACDF, Siena, Cause 1722-1723, fo. 92r-102v, 140r-148v.

ACDF, Siena, Processi, vol. 7, fo. 858r-899v; Cause 1595, fo. 150r-187v.

ADCF, Siena, Processi, vol. 13, fo. 761r.

ACDF, Siena, Processi, vol. 27, fo. 766r-767v.

ACDF, Siena, Denunce 1682-1688, fo. 386r-v.

ACDF, Siena, Cause 1723 (A), fo. 60r-70r. Sardini, who was sponte comparens, at the end of the trial abjured de levi.

5 Pietro d'Abano was an Italian philosopher and astrologist lived between the 13th and 14th centuries. The diffusion of the Lucidario in treasure hunting is also present in the 1579-1580 case of the Venetian patrician Cesare Morosini studied by Ruth Martin (Martin 1989, pp. 88-90).

46 ACDF, Siena, Processi, vol. 31, fo. 332r-347r.

47 ACDF, Siena, Cause 1721, fo. 219r-220r.
} 
when he was 14 or 15, he had been duped by Giulio and a person named Francesco da Castel del Piano (also known as "chiavaro", probably because his job was to make keys), who had persuaded him to pay for the travel expenses of all three to go to a place near Carrara in order to find a legendary treasure, but, once they got to the point where they should have found so much wealth left there "by a queen of distant countries" ("da una Regina di lontan paesi"), they found nothing ${ }^{48}$.

In some cases, actual excavation campaigns were organized with a large number of participants. These were huge "public" events—out in the open—in which different people worked together for the same purpose. There was the owner of the land where the pit was being dug (sometimes a patrician), a priest who exorcized the place, and the diggers who carried out the excavation. The latter were usually farmers or workers paid by the owners, or even people who lived in the neighborhood, and, attracted by the unusual, fascinating, and, above all, promising event, had made a deal with the others involved. About the role played by each treasure hunter acting in large or small groups, Dillinger suggested that usually there was an organizer, a magician (often a priest), and several supporters in most groups of treasure hunters ${ }^{49}$. In Southern Tuscany, this was actually true in public excavations, where the role of singles participants was clear, but, in several cases, the hunters were the people who searched for treasures individually. If could also happen that the priest was a magician as well as organizer, or that some lay people gathered to practice the spell in small groups, in which the roles were mixed up.

The presence of members of the clergy, who so frequently appear in our trials, reassured the participants of the lawfulness of what was happening, and-it is good to specify this-that the excavation itself was certainly not forbidden by the ecclesiastical authorities, but the use of those practices that the Catholic Church called "superstitious", as well as the exorcism of the pit (completed, besides, with liturgical vestments) constituted a crime for the Inquisition, which is why there are many cases of excavations witnessed by the inquisitorial documents. In addition to the already mentioned dig of Piancastagnaio in 1618, of which Sisto Sisti said "was hoed publicly and nothing was found" ("fu zappato publicamente e nulla s'è trovato") $)^{50}$, and the one of Cul di Paiolo near Arezzo straddling the 17th and 18th century, where a stone crucified Christ was found ${ }^{51}$, or even the one of Abbadia San Salvatore in $1722^{52}$, the demolition of a wall in the house of Pietro Gherardini in Pisa in 1612 can be mentioned, behind which a group of people thought to find a treasure ${ }^{53}$, or the "pit very deep, and large" ("una fossa, assai profonda, e grande") dug by some farmers near Siena during 1679, on the property of Maddalena Boninsegni, which amazed the priest who had been intrigued by news that he had heard around ${ }^{54}$.

\section{Concluding Remarks}

After this quick overview of the trial sources, in which we tried to focus on the main topics of the phenomenon of treasure hunting in Southern Tuscany, with particular attention to the sources of the Sienese Holy Office, it is appropriate to summarize the main topics of my paper.

The use of magic to find lost objects was a widespread custom in the past centuries, and Tuscany was no exception; the sources, in fact, prove its existence in the long term, from the Middle Ages to the early modern period, with a wide range of participants, both men and women ${ }^{55}$, of aristocratic and

48 ACDF, Siena, Processi, vol. 9, fo. 182v-184r. This is also a rare case, in which the guardians of the treasure (according to the legend reported by Julius and Francis) were not demons, but the souls of two Moors who had been killed by the queen in order to keep the treasure safe, as long as the queen's heirs had not come to claim what was rightfully theirs.

49 (Dillinger 2012, p. 147)

50 Supra, n. 41.

Cf. supra, n. 15.

Supra, n. 35

ACDF, Siena, Processi, vol. 25, fo. 374r.

ACDF, Siena, Denunce 1676-1681, fo. 753r-754v

55 The gender data is that women appear mostly in the magical searches of lost (or stolen) common-use objects, whereas men are usually frequent in treasure hunts. 
popular origins, both cultured and uncultured, who put into practice many attempts to find lost objects or hidden treasures. It is remarkable the presence of members of the low clergy, who contributed to the hunts with rites derived from the Catholicism, and carried out the important task of exorcising the presumed place of the treasure by the creatures that infested it as "guardians".

There were efforts to dissuade or suppress the treasure hunts. Some intellectuals, such as Georg Agricola and Giambattista Della Porta, pointed at the ineffectiveness of means like the divining rod, while the ecclesiastical authorities, represented by the tribunals of the Holy Office, concentrated themselves on the repression of the practices and beliefs that did not conform to Catholicism, including the use of objects, formulas, and rituals related to the liturgy for profane purposes, the divinatory magic used to find the exact place in which to dig (often associated with the invocation of the devil), or the belief in supernatural entities guarding earthly riches.

All of these cases raise the following questions: "What was the actual use of treasure hunting?", and "Where they ever found?" It is not entirely surprising that people were looking for valuables in the subsoil, especially in an area of ancient settlements like the Italian peninsula, where the possibility of finding artefacts from the past eras was not entirely improbable, and indeed the attention towards the remnants of ancient civilizations such as the Roman one rose during the Renaissance, with the affirmation of the antiquarianism; moreover, natural disasters and the wars that had taken place over the centuries had brought about death and destruction, but they had also inspired stories about valuables that had been lost and were just waiting to be found ${ }^{56}$. These legends caused real treasure hunts, which sometimes involved a large number of people, and gave rise to impressive excavations. This is an element of cultural history that historiography should perhaps investigate more. The great frequency of these events is even more enigmatic, considering that all of the efforts made never led to any treasure. Only in one case in the Sienese Holy Office documents, in 1721, is it stated that a mysterious golden goat with some golden crescents was found, and that it was sent to Rome, but the sources are not able to provide further details ${ }^{57}$. Even if this discovery was true (and this seems unlikely), it would be unique, as in the other studied cases, the enormous efforts made, despite the risk of being put before a judge, were in vain.

So why did people search for treasures that could not be found? All scholars agree on the attraction exercised by the possibility of acquiring wealth immediately (Jean-Michael Sallmann compared this desire to the alchemical attempts of turning poor materials into silver and gold $\left.{ }^{58}\right)$, but this explanation, which it is actually true in many cases, seems too simplistic, because, in this case, it should be common practice, especially for those who were in economic difficulty; instead, we saw rich patricians involved, as well as friars who had taken a vow of poverty. Furthermore, Matteo Duni wrote that the treasure hunts were a typical hobby of the upper and middle classes (but he added that it was not astonishing to also bump into the lower classes $)^{59}$, and Di Simplicio noted that it was a matter that involved a certain degree of education, to which not everyone could access ${ }^{60}$. In the analyzed sources, we saw a great variety of people involved, who searched for treasures in different forms-taking into considerations two extremes, there was the cultured patrician who read forbidden books and put into practice highly sophisticated rituals, and the farmer, who had heard about the use of the divining rod and tried to become rich in a simple way. They both had the same purpose and drew from the same legends and traditions, but each one reinterpreted them on the basis of his culture and his personal experiences.

For Dillinger, the fundamental meaning of the magical treasure hunts was economic, connected with the theory of limited good, "people in traditional societies behaved as if all goods were only

56 It is shown, in this paper, by the people who looked for treasures after the war of Castro (supra, n. 21), or those who searched in the rubble after the eruption of the Mount Etna and the earthquake (supra, n. 9).

57 ACDF, Siena, Cause 1721, cc. 406r-408r.

58 (Sallmann 1986, p. 164)

59 (Duni 1999, pp. 247-8).

60 (Di Simplicio 2005, p. 77). 
available in fixed quantities that could never be increased. Thus, one person's gain was necessarily the loss of anybody else. [ ... ] Material gain was only acceptable socially if it came from outside the society, such a treasure". In conclusion, for him, "treasure hunting was an integral part of the economic magic of pre-industrial Europe ${ }^{\prime \prime 61}$. It is a fascinating explanation, acceptable if we consider those cases in which the purpose of the search was merely economic, but, if we look closely at the Sienese inquisitorial sources, we note that other perspectives also come out. Not all those who were involved in the hunts wanted to be richer. The members of the clergy, for instance, usually participated in order to carry out their role as expert of the supernatural, and other people seemed to have been attracted more by the search itself than by the final prize. These different approaches show a more complex and variegated panorama that deserves to be further investigated.

Funding: This research received no external funding.

Conflicts of Interest: The author declares no conflict of interest.

\section{References}

Alessi, Giuseppe. 1834. Storia critica delle eruzioni dell'Etna. Discorso sesto. Dal principio al termine del secolo XVII, Atti dell'Accademia Gioenia di Scienze Naturali di Catania. Catania: Dai torchi di Giuseppe Pappalardo, vol. 8.

Amoretti, Carlo. 1808. Della Raddomanzia Ossia Elettrometria Animale. Ricerche Fisiche e Storiche. Milano: Presso Giuseppe Marelli.

Aron-Beller, Katherine, and Christopher F. Black, eds. 2018. The Roman Inquisition. Centre versus Peripheries. Leiden-Boston: Brill.

Bethencourt, Francisco. 2011. The Inquisition. A Global History, 1478-1834. Cambridge: Cambridge University Press. First published 1995.

Black, Christopher F. 2009. The Italian Inquisition. New Haven and London: Yale University Press.

Cifres, Alejandro. 2000. L'Archivio storico della Congregazione per la Dottrina della Fede. In L'apertura degli archivi del Sant'Uffizio romano. Giornata di studio (Roma, 22 gennaio 1998). Roma: Accademia Nazionale dei Lincei, pp. 73-84.

Cristelli, Franco. 2008. La ricerca di un tesoro a Cul di Paiolo ai tempi di Federigo Nomi. In Federigo Nomi. La sua terra e il suo tempo nel terzo centenario della morte (1705-2005). Edited by Walter Bernardi and Giovanni Bianchini. Milano: FrancoAngeli, pp. 239-56.

De Maria, Giacinto. 1898. La guerra di Castro e la spedizione de' presidii. Miscellanea di Storia Italiana 4: 191-256.

Del Col, Andrea. 2009. L'Inquisizione in Italia. Dal XII al XXI Secolo. Milano: Mondadori. First published 2006.

Di Simplicio, Oscar. 2005. Autunno della stregoneria. Maleficio e magia nell'Italia moderna. Bologna: Il Mulino.

Di Simplicio, Oscar, ed. 2009. Le lettere della Congregazione del Sant'Ufficio all'inquisitore di Siena. 1581-1721. Trieste: Edizioni Università di Trieste.

Di Simplicio, Oscar. 2010. Siena. In Dizionario Storico dell'Inquisizione. Directed by Adriano Prosperi, Vincenzo Lavenia, and John Tedeschi. Pisa: Edizioni della Normale, vol. 3, p. 1423.

Dillinger, Johannes. 2012. Magical Treasure Hunting in Europe and North America. A History. Basingstoke: Palgrave.

Duni, Matteo. 1999. Tra religione e magia. Storia del prete modenese Guglielmo Campana (1460?-1541). Firenze: Leo S. Olschki.

Eamon, William. 1994. Science and the Secrets of Nature. Books of Secrets in Medieval and Early Modern Culture. Princeton: Princeton University Press.

Golden, Richard M, ed. 2006. Encyclopedia of Witchcraft. The Western Tradition. Santa Barbara: ABC-CLIO, vol. 4. Kallestrup, Louise Nyholm. 2015. Agents of Witchcraft in Early Modern Italy and Denmark. Basingstoke: Palgrave.

Lavenia, Vincenzo. 2001. «Anticamente di misto foro». Inquisizione, stati e delitti di stregoneria nella prima età moderna. In Inquisizioni: Percorsi di Ricerca. Edited by Giovanna Paolin. Trieste: Edizioni Università di Trieste, pp. 35-80.

61 (Dillinger 2012, pp. 207-8). 
Lavenia, Vincenzo. 2013. La lotta alle superstizioni: obiettivi e discussioni dal Libellus al Concilio di Trento. Franciscan Studies 71: 163-181. [CrossRef]

Limonta, Roberto. 2017. Una più del diavolo. Divinazione, prescienza e futuri contingenti del De divinatione daemonum di Agostino d'Ippona. Dianoia 24: 3-14.

Lindow, John. 1982. Swedish Legends of Buried Treasure. Journal of American Folklore 95: 257-279. [CrossRef]

Macfarlane, Alan. 1999. Witchcraft in Tudor and Stuart England. London: Routledge. First published 1970.

Martin, Ruth. 1989. Witchcraft and Inquisition in Venice. 1550-1650. Oxford: Blackwell.

Masini, Eliseo. 1639. Sacro Arsenale, overo Prattica dell'Officio della S. Inquisitione. Roma: Appresso gl'Heredi del Corbelletti. First published 1621.

Mayer, Thomas F. 2013. The Roman Inquisition. A Papal Bureucracy and Its Laws in the Age of Galileo. Philadelphia: University of Pennsylvania Press.

Mayer, Thomas F. 2014. The Roman Inquisition at the Stage of Italy, c. 1590-1640. Philadelphia: University of Pennsylvania Press.

Montesano, Marina. 2018. Classical Culture and Witchcraft in Medieval and Renaissance Italy. Basingstoke: Palgrave.

Prosperi, Adriano. 2009. Tribunali della coscienza. Inquisitori, confessori, missionari. Torino: Einaudi. First published 1996.

Prosperi, Adriano, Vincenzo Lavenia, and John Alfred Tedeschi. 2010. Dizionario Storico dell'Inquisizione. Directed by Adriano Prosperi, Vincenzo Lavenia, and John Tedeschi. Pisa: Edizioni della Normale, vol. 4.

Sallmann, Jean-Michael. 1986. Chercheurs de trésors et jeteuses de sorts. La quête du surnaturel à Naples au XVIe siècle. Paris: Aubier.

Tedeschi, John. 1991. The Prosecution of Heresy. Collected Studies on the Inquisition in Early Modern Italy. Binghamton: CenThomas ter for Medieval and Renaissance Studies.

Thomas, Keith. 1991. Religion and the Decline of Magic. Studies in Popular Beliefs in Sixteenth and Seventeenth Century England. London: Penguin. First published 1971.

Valente, Michaela. 2015. Superstitione, heresia e ignorantia. Teoria e prassi inquisitoriale in alcuni casi di maleficia. In Prescritto e proscritto. Religione e società nell'Italia moderna (secc. XVI-XIX). Edited by Andrea Cicerchia, Guido Dall'Olio and Matteo Duni. Roma: Carocci, pp. 65-83.

(C) 2019 by the author. Licensee MDPI, Basel, Switzerland. This article is an open access article distributed under the terms and conditions of the Creative Commons Attribution (CC BY) license (http://creativecommons.org/licenses/by/4.0/). 


\title{
Debating the Devil's Clergy. Demonology and the Media in Dialogue with Trials (14th to 17th Century)
}

\author{
Rita Voltmer \\ Department (Fachbereich) III, History (Regional History), University of Trier, 54286 Trier, Germany; \\ voltmer@uni-trier.de
}

Received: 11 September 2019; Accepted: 8 November 2019; Published: 26 November 2019

\begin{abstract}
In comparison with the estimated number of about 60,000 executed so-called witches (women and men), the number of executed and punished witch-priests seems to be rather irrelevant. This statement, however, overlooks the fact that it was only during medieval and early modern times that the crime of heresy and witchcraft cost the life of friars, monks, and ordained priests at the stake. Clerics were the largest group of men accused of practicing magic, necromancy, and witchcraft. Demonology and the media (in constant dialogue with trials) reveal the omnipresence of the devil's cleric with his figure possessing the quality of a 'super-witch', labelled as patronus sagarum. In Western Europe, the persecution of Catholic priests played at least two significant roles. First, in confessional debates, it proved to Catholics that Satan was assaulting post-Tridentine Catholicism, the only remaining bulwark of Christianity; for Protestants on the other hand, the news about the devil's clergy proved that Satan ruled popedom. Second, in the Old Reich and from the start of the 17th century, the prosecution of clerics as the devil's minions fueled the general debates about the legitimacy of witchcraft trials. In sketching these over-lapping discourses, we meet the devil's clergy in Catholic political demonology, in the media and in confessional debates, including polemics about Jesuits being witches and sorcerers. Friedrich Spee used the narratives about executed Catholic priests as vital argument to end trials and torture. Inter alia, battling the devil's clergy played a vital role in campaigns of internal Catholic church reform and clerical infighting. Studying the debates about the devil's clergy thus provides a better understanding of how the dynamics of the Reformation, counter-Reformation, Catholic Reform, and confessionalization had an impact on European witchcraft trials.
\end{abstract}

Keywords: witchcraft; superstition; magic; counter-reformation; media; Catholic reform; Franconia; Bavaria; Trier; Germany; France; Italy; Spain; Jesuits; priests; monks; Inquisition; exorcism; convent cases; witch-hunts

\section{Introduction}

\subsection{Catholic Clergy as the Devil's Minions-Thesis}

Witch-priests were a special category of male witchcraft not in quantity, but certainly in quality. In late medieval and early modern Western Europe, members of the Catholic clergy (parish priests, canons, monks, friars, Jesuits) were accused as magicians, sorcerers and witches. ${ }^{1}$ Not all of them suffered execution, banishment, or died in custody. Including an obscure number of cases lost in the

1 For reasons of linguistic variations, I use the terms "witch-cleric", "witch-priest", "sorcerer-priest", "priest-magician", or "wizard-monk" as synonyms without any inherent textual difference. In German, the term "Hexenpfaffe" or "Zauberpfaffe" appears in the source material-I owe my gratitude to the anonymous reviewers for encouragement and comments. Most of all, I like to thank the one reviewer who had lent a helping hand in language editing. My final thanks are going to Marina Montesano for inviting me to write this paper, and to Alison Rowlands for comments and a final language editing. 
archives, we can estimate a total of about 120 to 150 witch-clerics, sorcerer-priests, and wizard-monks who had to stand trial under the accusation of ritual magic, necromancy, and witchcraft. ${ }^{2}$ As far as we know, members of the Jesuit order did not share the fate of the executed ${ }^{3}$, other than in 1731 during the last French witch-trial, when the Jesuit Father Jean-Baptist Girard was condemned to death, but pardoned by the parlement de Paris (Kuznicki 2007). During the polemical confessional debates of the 16th and 17th centuries, notably in the Old Reich and its borderlands, members of the Societas Jesu were defamed as the devil's sorcerers. In actual witchcraft trials, Jesuits—as other clerics—were the target of denunciations made by condemned witches. The situation grew worse after some Jesuits, working as father confessors of witches in the prison, raised their voices against the cruel procedure of trials and torture. Witch-hunting commissioners from Westphalia accused them consequently of being patroni sagarum (protectors of witches) and thus witches themselves. In the different confessional factions, this potentially deadly argument fueled the polemical discourse about ecclesiastical prince bishops who were-according to Luther's concept-spiritual sorcerers and so-called witches' masters (Hexenmeister), conducting terrible witch-hunts and shedding the blood of the innocent (Voltmer 2020). Friedrich Spee, finally, joined in the chorus, using the example of witchcraft trials against Catholic priests as a vital argument against further prosecution (1631).

During the so-called convent cases in France, the Old Reich, and their borderlands as well as in Italy, several nuns and female religious figures who, according to Canon law, did not belong to the status of clergy, participated in witchcraft trials as possessed living saints, accusing either their father confessors or other nuns of being witches. (Burkardt 1997; Ferber 2004; Po-Chia Hsia 2005, pp. 144-58; Monter 2007, pp. 97-100). ${ }^{4}$ So far, the total number of nuns and women religious, who were executed as presumed witches, is unknown. Renata Maria Singer von Mossau was the 'last witch' from Franconia, put to death in the Holy Roman Empire in 1749. Several nuns had accused her of having harmed them through demonic possession. The Jesuit Father Georg Gaar published the sermon which he had preached at the stake and in which he defended the necessity of the witch trial (Muschiol 2004, p. 78; Levack 2013, p. 220).

Protestant ministers, on the other hand, lived a safer life until the mid-17th century. With only a few accused of witchcraft, only four of them were executed as witches: John Lowes in Sussex (1645), Kaspar Dulichius in Saxony (1655), Andreas Koch in Lemgo (1666), and George Burroughs in Salem (1692) (Rowlands 2019, p. 9). ${ }^{5}$

In comparison with the estimated number of about 60,000 burnt, hanged, decapitated, or lynched supposed witches (women and men), the number of executed and punished witch-priests seems to be rather irrelevant. ${ }^{6}$ This statement, however, overlooks the fact that it was only during medieval

2 For example, the total number of clerics, who were accused as necromancers, magicians, and wizards in Italy and Spain, is not known. In both regions, tribunals of the Roman and Spanish Inquisition as well as secular courts prosecuted magic, sorcery, and witchcraft; see (Knutsen 2009, pp. 5-7, and in the present chapter footnotes 17, 20-22).

3 Urbain Grandier, executed in 1634, had not been a Jesuit, presumed by Apps and Gow (2003, p. 57) - A survey of the Capuchin's involvement in witch-hunting has yet to be written; see pars pro toto (Tschaikner 2010).

4 Johannes Wier reported-together with the story of the witch-cleric from Mirandola-the first cases of demonic possession and witchcraft accusations in female convents. He argued against staged exorcisms, because they triggered the fear of diabolic witchcraft and resulting trials (Voltmer 2016, p. 212). The notorious convent cases of Aix-en-Provence, Lille, Loudon, and Louviers reached wide spreading public attention (Dall'Olio 2006). Additionally, the Lorraine demonical possessed 'living saint' Elisabeth Ranfaing caused the execution of the physician Charles Poirot (1622) as a supposed witch. This case was copied in Cologne, where a possessed 'living saint', the nun Sophie Agnes von Langenberg, accused Katharina Henot as a witch. A witch-hunt started which cost about 24 lives. The network of the Jesuit order played a vital role in transmitting the idea of staging the making of a 'living saint' with the help of exorcism (Voltmer 2018, pp. 160-61; Levack 2013, pp. 145-55)—The Jura region (including the Franche-Comté) "had no bewitched convents or priest-sorcerers" (Monter 1976, p. 195).

5 In 2009, I worked out a preliminary survey concerning the figure of the witch-cleric during the European witch-hunts ('Geistliche im Hexenprozess_-Versuch eines Überblicks', unpublished conference paper). I shared the paper with my friend and colleague Alison Rowlands to use in her study of witch-clerics in a Lutheran context (Rowlands 2019, pp. 15-16, footnote 79) - The present paper is part of a recent book project.

6 A cluster of factors triggered major witch-hunts, including demands from the populace. Recent witchcraft research denies any monocausal explanation. This paper cannot discuss these factors in detail; see pars pro toto (Voltmer 2017b). 
and early modern times that the crime of heresy and witchcraft cost the life of so many ordained priests. ${ }^{7}$ Clerics "probably comprised the largest single group of men accused of practicing magic" (Mollenhauer 2006, p. 197). Demonology and the media debated the devil's clergy during medieval and early modern times in constant dialogue with actual trials. ${ }^{8}$ This omnipresent figure possessed the quality of a 'super-witch', labelled as patronus sagarum. After the Reformation and during the movements of counter-reformation and Catholic reform, at least four discourses filled with confessional arguments: Protestant polemics about Jesuit-sorcerers seeking global tyranny; Protestant polemics about popish lands teeming with witches; Catholic propaganda about being the last bulwark against witches, Anabaptists, Protestants, and Jews; finally the discourse in the Old Reich about the legitimacy of massive witch-hunts, joined by sceptical Jesuit voices. The figure of the priest-witch appeared prominently in these overlapping debates, which shared arguments and transgressed-where necessary-confessional borders (Clark 1997, pp. 195-213, 526-45). In addition, the trans-confessional anxieties about the heretical sect of the Anabaptists fueled Catholic as well as Protestant suspicions about clerics and ministers baptising their flock in the name of the devil. In Italy, France, or in the Old Reich, the witch-priest sometimes fell prey to campaigns for inner Catholic church reform and clerical infighting, embedded in old and new rivalries. Studying the debates about the devil's clergy thus provides a deeper understanding of how the dynamics of counter-reformation, Catholic Reform, and confessionalization ${ }^{9}$ had an impact on European witchcraft trials. ${ }^{10}$

\subsection{Setting the Scene-Catholic Clergy and the Crisis of Priestdom}

To analyze the multi-faced figure of the witch-priest, its appearance in discourse, and its impact during the late medieval and early modern witch-hunts, one must take into account that the status of the clergy contained within it a great diversity in rank, social milieu, economic resources, and location (rural/urban). ${ }^{11}$ Most students at medieval universities were qualified to be clerics. They were ordained to the lower orders and subject to Canon law, but without being priests in the fullest sense. Divided into secular clerics (e.g., canons, parish priests) and regular clerics (monks and friars, post-1560 Jesuits), not every cleric obtained consecration to the highest order of priesthood (Kieckhefer 1990, pp. 153-56). Minor clerics only possessed the lowest ordination. Noble clerics, from canons to bishops, gained a lower ordination only before entering their sinecures. Noble families parked their later-born sons in urban canonries to grant them a secure income and status. Sometimes, canons had to leave the clergy to take the place of a deceased main heir. Others changed profession. In many cases, however, it remained uncertain whether a so-called cleric had received any ordination at all. Canons in colleges lived the worldly life of the nobles or bourgeois elite, rejoicing in clerical privileges and rich sinecures, but neglecting their spiritual duties. For reasons of maintenance, many parents forced some of their later-born children into monasteries and nunneries. For the same reasons, young men together with their families hunted for pre-bends. These positions promised lifelong sustenance for the cleric and his entourage. Most parsons had to share their life with a woman for economic reasons who was able to fulfill the daily duties of housekeeping. It was a common and mostly accepted way of living for a rural

7 No statistics exist of how many ordained priests, monks, friars, or women religious were executed as heretics during the Middle Ages. The death toll increased during the 15th century, and especially during the Reformation era, including Protestant ministers and preachers. Some sixty-seven Jesuits were executed as martyrs during the religious conflicts of the 16th and 17th centuries in Europe. More Jesuits were killed or martyred in the transatlantic colonies (Rafferty 2017, p. 507).

8 A close connection between demonology and witch-hunting existed as a multi-levelled flow of ideas and practices. With the help of the media, and between the elite and popular domain ideas of demonology were negotiated, elaborated, and popularized; see the chapters in (Goodare et al. 2020).

9 On reformation, counter-reformation, and confessionalization, there is a still growing bibliography; among other titles see (Mullett 2010; Bamji et al. 2013).

10 The movements of Reformation and Counter-Reformation exerted a significant influence on witch-hunts in Europe; see for example (Kallestrup 2018; Monter 1976, 1990; Voltmer 2015, 2016, 2017a, 2018b, 2020; Waite 2003b, 2007, 2012)—On the scholarly debate and the call for further research see (Waite 2013, pp.485-487, 504).

11 See for example (Po-Chia Hsia 2005; Thibodeaux 2010; Arnold 2014). 
parish priest to maintain a concubine, to father children, and-sometimes—to invest a son as his vicar. Many a parson with his clerical magic served his flock with healing, cunning, and detecting witches' mischief (Mollenhauer 2006; de Blécourt 1994). To become a priest in an urban or rural parish, young men had informally to learn the art as an apprentice of an older parson. Vicars, hirelings, and chantry priests had to search for a patron who might invest them with a benefice. It was only after the Council of Trent that the training of priests in seminaries, mostly run by Jesuits, the evaluation of the applicants by specially appointed committees, and the control of their rightful ordination became obligatory. Still, many clerics and priests wandered from diocese to diocese to find an adequate position.

Catholic clergy in medieval and early modern times, however, stood apart from the laity through their legal status, privileges, conduct, and particularly sacrosanctity. At the highest order, an ordained Catholic priest was able to perform the seven sacraments (inter alia Eucharist, baptism, penance, and reconciliation). Due to his consecration, he was empowered to expel devils and demons with exorcism. In preaching, he was the voice of God, and in using the sacraments, he was the mediator between God and humankind. The Council of Trent reinforced the sacrosanct position of the clergy, and its exclusive power to perform the sacraments and the sacramentals, including exorcism (Levack 2013, pp. 96-98; Delumeau 1977, pp. 4-6, 13-15). A pious priest was a safeguard for his flock, a guarantee for its salvation, whereas a diabolic priest, a magician, necromancer, soothsayer, and cunning man, was a wolf amongst the sheep, a false prophet who brought with him the foul danger of the devil's baptism, blasphemy, lechery, and desecration of the sacraments. God's wrath had to come upon those who did not stop the devil's clergy from working their evil mischief. Whatever level of ordination a student, a secular, or a regular cleric had achieved, however, they all possessed the privilegium fori (benefit of clergy): A cleric thus had not to stand trial in a secular court nor be tortured, unless his degradation had discharged him from his clerical status.

In the 14th and 15th centuries, ideas about the Apocalypse and the Antichrist gained ground. England and France were still in conflict, with civil wars and peasants' revolts in both countries; the Great Schism split Christendom between Avignon and Rome; heretic sects such as the Lollards and the Hussite movement fought for the renovation of Christendom. After the fall of the Byzantine Empire in 1453, the riders of the Apocalypse seemed to approach Christianity: War, with the advance of the Turks; plague, with the spread of the yet unknown deadly disease of syphilis; famine and death, as consequences of weather disasters, deluge, and drought. Apocalyptic thinking fueled the obsessive clerical idea that certain conspiracies in the service of Satan existed which together formed a secret army to battle Christianity in a final Armageddon (Clark 1997, pp. 346-62). These anxieties partly forwarded harsh anticlerical criticism, which since the 14th century, during the pre-reformation and reformation period had increased against so-called lecherous canons, wandering friars, pseudo-clerics, and idle monks (Stephens 2002, pp. 303-4). The underworld of necromancy, love magic, magical healing, soothsaying, stargazing, and treasure hunting provided a large field of action. At noble courts, in urban as well as in rural parishes, clerics advertised their power in misusing the sacraments, dealing with hosts, re-baptising, and summoning demons (Boudet 2019; Klaassen 2019; Montesano 2018, pp. 170, 180; Cameron 2010, pp. 61-62, 116; Veenstra 1998; Kieckhefer 1990, pp. 151-75). ${ }^{12}$

Demonology brought forward the argument that vagabonds, Hussites, magicians, witches, and heretics multiplied, secretly infiltrating Christian society. Members of the 'clerical underworld', who practiced necromancy and ritual magic, seemingly belonged to this army of the devil (Tschacher 2000; Bailey 2003, 2019). During the Schism, the figure of the sorcerer-pope as an adherent of the Antichrist (or as the Antichrist himself) had already played a vital role in defaming political adversaries. This narrative, marking the pope, the Catholic cleric and every papist into sorcerers and witches, gained particularly relevant impact during the confessional debates that were to come (Harvey 1973;

12 During the medieval and early modern period, clerics engaged frequently in magical treasure hunting. A notorious trial happened in Lyon (1742-1745), including several priests (Dillinger 2012, pp. 130-34). 
Kieckhefer 1990, pp. 155-56; Hillgarth 1996; Cameron 2010, p. 210; Parish 2015; Ficzel 2019). ${ }^{13}$ There were several steps to take from the concept of learned ritual magic (necromancy) to diabolic witchcraft, amalgamating both concepts with the blasphemous crime of heresy, and the adoration of demons at the witches' sabbath (Ostorero 2019; Utz Tremp 2008).

During the 15th, 16th, and 17th centuries, attempts of Catholic reform and counter-reformation exposed that the papal Church had endured a massive crisis of the priesthood. Anticlericalism, built on political, social, economic, and religious enmities, indeed, had a longstanding medieval tradition. It targeted regular and secular clergy, whilst there was a great deal of infighting amongst the clerical orders themselves: Monks battled friars, observant defamed non-observant branches, Dominicans battled with Franciscans, anti-fraternalism ruled from the advent of the Mendicant orders, and popes were labelled as diabolic necromancers. These polemics increased during the Reformation period, together with the radical anticlericalism of the Anabaptists (Waite 2003a). After 1560, new rivalries grew between the Jesuits, the Mendicant orders and the secular clergy (canons, beneficed rural as well as urban priests). ${ }^{14}$

However, counter-reformation worked slowly. Even after the Council of Trent, rural parish priests lived with their concubines and children, neglecting the new pastoral and moral guidelines. Some of them had only sparse knowledge of their spiritual duties, of performing the sacraments, preaching, and teaching their flock the dogma of Catholic Church. Instead, they acted as cunning men, with some becoming famous because of their magical healing powers. Popular anticlericalism thus held parish priests as sorcerers and magicians responsible for bad weather, harvest failure, and impotence (Roelants and Vanysacker 2005; Robbins 1997). In an urban context, the worldly lifestyle of the canons gave reason for many complaints. In the eyes of Catholic reformers, clerical conduct and education needed a firm and groundbreaking redesign to withstand the devil's two-fold challenge, firstly from within by unlearned, wicked priests, and superstitious people, and secondly from the outside by heretical sects (Anabaptist, Protestants, and witches) and Jews who had already fallen prey to Satan (Waite 2003b, 2007, 2012). Against the backdrop of these realities and fears, the figure of the sorcery-priest gained the quality of a threatening danger to Christian society itself. The Catholic witch-cleric thus was not a stereotype developed at the peak of witch-hunting, leading to its breakdown ("crisis of confidence"; Midelfort 1972, pp. 121-63). Influenced by the medieval concepts of apocalypse, heresy, and anticlericalism the devil's cleric had accompanied female and male witches at least since the 15th century (Stephens 2002, p. 5).

However, how was it possible to unmask the false prophets, shielded as they were by their privileges? Demonology and most of all, a new set of Catholic standards delivered the categories to detect witches of all kind, including the priest-witch. During the post-Tridentine campaigns, these standards had been developed and provided by its strike force, the Jesuit order, together with those seminary priests who had been educated at its schools, colleges, and university faculties. In the Old Reich, in the Spanish Netherlands (together with Luxembourg), in Lorraine and Alsace, in Bohemia and Silesia, the ruling houses of Habsburg, Lorraine, and Wittelsbach promoted the establishment of these bulwarks against Protestantism. As nurseries of Catholic reform and counter-reformation, the Jesuits produced the ideal of an ascetic, pious, and learned priest, ready to fight the enemies of God to the point of martyrdom. These newly created men of God stood in apparent opposition to the

13 In general, accusations "of witchcraft and magic were used against the papal office and against individual popes in order to undermine the reputation of the individual and the respectability of the institution or in the service of political or personal rivalries and ambitions" (Parish 2015, p. 417). For example, and by 1611, the English mathematician and theologian John Napier listed twenty-two popes as necromancers (Parish 2015, p. 416). The Lutheran minister and missionary Hermann Samson, who in Riga battled both Catholics and Calvinists, stated in 1626 that all popes were witches, a fact easily to be proved, because popish lands sheltered more witches than anywhere else. Jesuits however headed his list of witch-clerics, being (allegedly) very prone to witchcraft. In defaming Catholics as witches in general, Samson relied on Luther and Bodin (Schulte 2009, pp. 134-36).

14 See for example: (Parish 2015; Tronu 2015; Stolarski 2011; Geltner 2012; Voltmer 2010a; Dykema and Oberman 1993). 
highly criticized and ridiculed members of the old, lecherous, corrupt, worldly, unlearned, and idle clergy, suspected of superstition and witchcraft. Thus, at the end of the 16th century, and up to the first third of the 17th century, members of the Jesuit order worked hand in hand with the persecuting ecclesiastical and secular authorities to battle the witch-priest, e.g., in Trier, Cologne, the Eifel region, Franconia, Swabia, Alsace, or Lorraine. However, after 1600, a change of opinion slowly spread in the order, which brought a few Jesuits to think differently about the crime of witchcraft, and about the accused clerics. They joined the empire-wide critical discourse about the legitimacy of massive witch-hunts, which did not respect the lives and souls of the innocent. ${ }^{15}$

\subsection{The Witch-Cleric-Research Concerning the Old Reich and Its Border Lands}

A history of the witch-cleric in Europe is still missing. ${ }^{16}$ A rather outdated survey concerning Catholic witch clerics in German speaking areas (Holy Roman Empire, Habsburg Hereditary Lands in Tyrol, Carinthia, Styria, and Salzburg) concentrates on the 16th and the 17th centuries, and rejects the concept of social disciplining as explanation (Schwillus 1989; Schwillus 1992). For example, during the witch-hunts in Würzburg with its 43 canons and five alumni executed, well-known unworthy, lecherous priests escaped trial. The first denunciations against the priests arose from urban and rural convicted witches. However, during interrogation under torture, leading questions asked the accused to name his specific accomplices, leading to further denunciations against members of the three collegiate chapters in Würzburg (Schwillus 1989, pp. 70-71). This criminal procedure proves two facts: Firstly, the inquisitors eagerly sought for more witch-canons, and secondly, in answering the questions, the imprisoned canons had no alternative but to give the names of their fellow canons.

A triggering factor in Würzburg might have been social envy against the idle and immoral conduct of (noble) canons. Members of the Jesuit order, who opposed the worldly life of the canons, had taken some lead during the trials. Schwillus, however, denied any special significance of the phenomena, since only a small number of clergymen had fallen prey to the witch-hunts. In 2004, Gisela Muschiol did an initial survey of both religious women and men being involved as victims, witnesses, and perpetrators in witch trials. Members of the clergy seemed to be treated in the same way as members of the laity. On the one hand, parish priests were probably denounced as witches because they shared their daily life in face-to-face communities with other suspected people. On the other hand, Muschiol assumed a connection between Catholic reform, counter-reformation, confessionalization, and witchcraft trials against members of the clergy (Muschiol 2004, pp. 77, 88). In 2005, Nienke Roelants and Dries Vanysacker presented a survey concerning the Catholic clergy in parts of the Southern Netherlands and its attitudes towards superstition and witchcraft. Though local parish priests participated in magical and semi-religious actions, no names of accused clerics were found in the surviving records of Brabant, Brussels, Antwerp, and Ghent (1550-1650). Additional documents revealed two cases of parish priests who were punished, but not executed or exiled because of so-called superstitious practices (Roelants and Vanysacker 2005, pp. 769-70, 782, 789-90). However, between 1608 and 1619 some female convents were allegedly infested with demonic possession and witchcraft, for example in the abbey of the Brigittines at Lille (1610) and in the Cistercian abbeys of Valduc (1610), Beaupré (1611), and Notre-Dame-du-Verger (1613-1619). In subsequent trials several nuns were executed as witches, many more had to stay in prison for several years (Roelants and Vanysacker 2005, pp. 778-80).

In 2009, I presented six categories of men charged as witches during the massive and well-documented witch-hunts in the Rhine-Meuse-area: The boy-witch, the witch-hunter, the adversary

15 Jesuits were involved in witch-hunting at almost every level of action, be it as demonologists or sceptics, as exorcists, preachers and father confessors, during prison ministry as well as missionary and visitation travels, as experts at the faculties of theology, or as advisers of princes (Voltmer 2006, 2016, 2020; Sobiech 2019).

16 The so-called convent cases of France, Italy or Spain are well known; see inter alia (Walker and Dickerman 2001; Ferber 2004; Dall'Olio 2006, 2012; Spence 2009; Watt 2007, 2009; Tausiet 2013, p. 195; Maus de Rolley 2016)—Witch-clerics appear marginally in (Dinzelbacher 2006, p. 179; Schulte 2009, pp. 78, 97, 135, 259; or Apps and Gow 2003, pp. 33, 57, 144). 
(political/socially), the rogue (adulterer), the cunning man, and the priest. At least four out of the six had fallen under suspicion because of the Jesuits' missionary work (child-witch, rogue, cunning man, and priest). I divided the latter category into three subcategories: Firstly, some parish priests were accused because they had joined their lives and their beds with concubines who already were tried for witchcraft and infanticide. ${ }^{17}$ Subsequently, they denounced their priestly lovers (and sometimes violators) as instigators of the child's murder and as ringleaders of the witches. A second group of priest-witches attracted suspicion because they acted as cunning men, fueling superstitions, and misusing sacramentals. Thirdly, some of these clergymen, who had acted as confessors of condemned witches, were accused as patroni sagarum, because they had openly opposed the procedure of witchhunting (Voltmer 2009, pp. 89-90). In her study on Lutheran witch-clerics, Alison Rowlands worked successfully with the categories to characterize the Protestant witch-cleric. These ministers were charged with witchcraft relatively late in the cycle of early modern witch-persecution. In the rural hinterland of Rothenburg ob der Tauber, two Protestant witch-clerics were accused of having baptised children to the devil (1639: Johann Mauck; 1692: Johann Craft). Rowlands argues for the impact of the media, of pamphlets and leaflets which translated anxieties about the Catholic witch-cleric into the Protestant milieu. She suggests that the denunciation of Jesuits as witches had probably stopped enthusiasm for further trials (Rowlands 2019, p. 21).

In 2018, I published the first critical edition of an almost entire trial record against a Catholic priest under the charge of witchcraft (Voltmer 2018b, pp. 289-322). ${ }^{18}$ The case of Father Laurenz Kirsbach from a small Eifel-village presents the extraordinary story of a parish priest who was able to escape to Cologne to avoid a witchcraft trial but was captured and executed in 1631. Not only the records but likewise letters of the secular minor lord, who had persecuted Father Kirsbach, have survived, opening a new perspective behind the scenario. The case shows in detail the significance of a criminal trial against an ordained priest: According to his letters, the lord Bertram Beissel of Gymnich prosecuted Laurenz Kirsbach to save the souls of the priest's flock, whom the latter had allegedly baptised to the devil. Educated by Jesuits, Bertram as a second-born son had obtained lower ordination as a cleric to be invested as a canon in Trier and in Paderborn. After the death of his older brother, he surrendered his canonries to take over the lordship of Schmidtheim. In constant conflict with his not yet retired father, who had been an expert in witch-hunting himself, Bertram unleashed a witch-hunt in the small village of Schmidtheim with the help of the witch commissioner Johannes Moeden, a trained legal expert (Voltmer 2015, pp. 172-79; 2018b, pp. 64-136). From April 1630 to April 1631, 42 supposed witches, women, and men, were burnt, thus almost half of the total adult population. Many of them had denounced the old parish priest Laurenz Kirsbach as the super-witch of the village. In dialogue with the Jesuits of Münstereifel and the vice general in Cologne, Bertram lent a helping hand to hunt down the escaped parish priest. The lord, the Jesuits, and the ecclesiastical administration joined the same post-Tridentine quest to purify Catholic lands of priest-witches, whose baptising into witchcraft and wicked pastoral care had lured simple people into the devil's snare. The prosecuting faction must have thought that they had detected a network of witch-clerics in the northern part of the Eifel with the rural priests Petrus Hildenbrandt († 5 February 1630), Michael Campensis († March/April 1630), and Matthias Hennes († 15 May 1630) already executed as witches, and other rural priests on the run. Bertram claimed that during the trial his former parish priest Laurenz would reveal the identity of many more witch-clerics in the service of Satan. The lord's prophecy became true: Kirsbach named eight more parish priests as his accomplices, conducting at the witches' sabbath black masses and

17 The story of the clerics' housekeepers and concubines, who were accused as necromancers and witches, likewise, has to be written. It is obvious that anticlerical zeal attacked "priestly immorality through their partners" (Waite 2007, p. 75)-In Modena, several concubines of priests offered their service as necromancers and sorceresses (Duni 2007, p. 71).

18 Most records of witchcraft trials against Catholic clerics are lost. For example, the notorious witch-hunts in Würzburg, in which more than 50 canons and Alumni were denounced, left over only three records. No trial records from witchcraft trials involving clerics in Westphalia, Trier, or in St Maximin survived. Beyond the trial records of Father Kirsbach, only fragments have survived concerning the Eifel territories. 
baptism in the name of the devil. The post-Tridentine impact of the involved Jesuit Fathers from Cologne and Münstereifel (missionary work, sermons, exorcism) emerged as a most relevant factor triggering the prosecution of witch-clerics (Voltmer 2016, 2018b). ${ }^{19}$

\section{The Witch-Cleric in Catholic Political Demonology}

\subsection{Examples}

Since the high Middle Ages and with the legend of Theophilus making a pact with Satan, a priest as Arch-Faustus had already entered the scenery of medieval liturgical drama (Bauer 2018, pp. 14-20; Baron 2019, pp. 6-7, 135). Monks and priests belonged to the first targets of diabolic seduction attempts according to medieval exempla (Brakke 2006; Kieckhefer 1990, pp. 172-75), primarily because the devil almost and always tried to ensnare the most pious men and women. Secondly, in thinking within transcendency there existed only a very thin line between sacrosanct powers of healing and conversing with saints and angels on the one hand, and necromancy or communicating with demons, on the other hand. Clerics and inquisitors-with their persecuting experience and obsessed with the omnipresence of demons, devils, and the threat of heresy-developed new demonological concepts (Utz Tremp 2008, pp. 411-40; Bailey 2001). At the beginning of the 14th century, Pope John XXII instigated trials against clerics (and laymen) who had used ritual magic with the invocation of demons as instruments of conspiracies and assassination (Utz Tremp 2008, pp. 406-16; Boureau 2004; 2006, pp. $16,18,21-25,37-39,59,82){ }^{20}$ From the 1320 s onwards several magician-clerics, classified as heretics, were incarcerated or executed (e.g., the bishop of Cahors Hughes Gérard in 1317).

In the 15th century, more and more stories circulated about Catholic clerics who had been recently executed as witches. Theological and legal thinking about the devil and his minions thus gained sublime evidence. The figure of the devil's clergyman obtained almost omnipresence in Catholic demonology. In 1453, the Benedictine monk, preacher, and Master of Theology Guillaume Adeline was charged by the inquisition of belonging to the diabolic sect of witches. Rumors and accusations had flown about him since the 1430s, mostly because in his sermons, he had argued against the reality of the witches' sabbath and their supposed flight. The inquisition sentenced him to lifelong incarceration. Adeline died four years later. For many later demonologists (e.g., Nicolas Jacquier, Pierre Mamoris, Jean Bodin, Martin Delrio) the defamatory narrative about this clerical patronus sagarum proved the serious dangers of the new witches' sect which was infiltrating Christian society (Ostorero 2003). In general, Jacquier counted clerics as prominent attendees of the witches' sabbath (Schulte 2009, pp. 97-98). We find the witch-cleric likewise in the Malleus Maleficarum (Rowlands 2019, pp. 4-5).

In Italy, the Malleus Maleficarum influenced the work and writing of Dominican inquisitors such as Giovanni Cagnazzo, who in Bologna campaigned against necromancy and witchcraft. The trials, which targeted women and men, cost inter alia the life of a priest and a friar (Herzig 2011). ${ }^{21}$

19 In the county of Manderscheid-Blankenheim together with the small lordship of Schmidtheim (both in the Eifel region), four parish priests were executed as witches. In the duchy of Westphalia and in the electorate of Cologne, we know about at least four parish priests tried as witches (1591-1630). Many denounced priests from Westphalia and Cologne fled by using clerical networks. Four monks of the Augustinian monastery of Dalheim (in the prince-bishopric Paderborn) were accused of witchcraft in 1600; one died in custody, the others were freed; see (Decker 1978, p. 326; 2003, pp. 165-66; 2000; Schormann 1991, p. 157; Voltmer 2018b, pp. 117-24; Sobiech 2019; Decker, Rainer. 1981/1982. Die Hexenverfolgungen im Herzogtum Westfalen. Westfälische Zeitschrift 131/132: 339-86, pp. 358, 368).

20 In early modern Papal Rome, the Inquisition fought necromancers and magicians (Decker 2008, pp. 132-44). For example, in 1635 a conspiracy had tried to assassinate Pope Urban VIII by ritual magic. The involved clerics and friars were condemned to execution or to the galleys (Rietbergen 2006, pp. 336-75).

21 Rivalries between the Mendicant orders surfaced during the campaigns of Dominican inquisitors. Necromancy and invoking demons were part of Renaissance culture in Bologna, joined by priests and friars as well as male and female lay people. Cagnazzo triggered a more severe punishment of these members of the clerical underworld-Tribunals of the Roman Inquisition and the Spanish Inquisition accused many clerics as necromancers and magicians, but condemned only a few to be executed; see for example (Monter 1990, pp. 176-79; Duni 2007, pp. 71-72; Herzig 2011, pp. 60, 68-69, Herzig 2011, pp. 1052-53; Tausiet 2013, pp. 35-57, 203). 
In 1522/23 a witch persecution occurred in the small lordship of Mirandola (Northern Italy), where seven of the ten executed persons were men, inter alia the parish priest Don Benedetto Berni (Montesano 2018, pp. 214-15; Stephens 2016; 2002; Maggi 2006, pp. 25-65; Herzig 2003; Costa 1990). Several other priests were denounced as members of the witches' sect. Benedetto became the prototype of the lecherous witch-cleric. Gianfrancesco Pico della Mirandola's tract Strix (published in Latin in 1523) rejoiced in the story of the old parish priest, seemingly addicted to his demon lover. Subsequently in 1525, the narrative was copied down in the very influential demonology of Paolo Grillando, a papal judge, first acting in the district of Rome, later in Arezzo. He had led and supervised several witchcraft trials, a first-hand experience, which he included in his treatise, where he presented a plausible explanation for his writing: The witches' sect infested society, deluded and seduced the simple folk successfully, most of all because its ringleaders and prominent members were clerics (religiosi). Grillando not only provided cases for his readers, but likewise legal advice on how to proceed against clerics who had in their diabolic deeds (including love magic) misused the host, the sacraments, and baptism (Lea 1939, pp. 395-412). After the re-organization of the Inquisition and with the impact of the Council of Trent, the persecution of clerical necromancers and wizard-priests increased remarkably. In Italy, clerics accused as necromancers or magicians, were charged more often, but not punished severely (Duni 2007, pp. 71-72). ${ }^{22}$

In 1580, Jean Bodin, including the example of Father Berni, referred frequently to Satanic priests misusing the sacraments for ritual magic, dealing hosts to witches, baptising toads, and feeding them with the Host (Schulte 2009, p. 259; Bodin 2011, pp. 132, 138, 215-16). For Bodin, the sorcerer-priest was the most horrible and blasphemous witch. He referred to a curate of Soissons, who according to Froissart, had been burnt alive because of ritual magic and sorcery.

Like Pico, Grillando, and Bodin, the suffragan bishop of Trier (Treves), Peter Binsfeld, in the second edition of his tract (1591) referred to actual witchcraft trials against ordained priests. In line with his peers, Binsfeld tried to weaken John Wier's argument that only mentally disturbed old women were wrongly accused of witchcraft. On the contrary, argued Binsfeld, recent witchcraft trials against rich and learned men, including members of the clergy, proved that the devil's minions had undercut Christian society. Even the sacrosanct status of the clergy had already fallen prey to the devil (Voltmer 2001). ${ }^{23}$

Martin Delrio, SJ, bolstered the argument to battle the witch-religiosi in his Disquitiones magicarum libri sex, recommending how criminal courts must treat monks, nuns, and clerics charged with witchcraft (Maxwell-Stuart 2000, pp. 216, 235-36). The story of the monk Jean Delvaulx of Stavelot-Malmédy, executed in 1596 as a witch, was on top of Delrio's list of prominent male witches. ${ }^{24}$ It became one of the prominent examples of a devil's cleric in demonology (Boutcher 2017, pp. 191-98; Machielsen 2015, pp. 248-9; Maxwell-Stuart 2000, pp. 5-7, 190, 213-14). Most noteworthy, Delrio labelled the Catholic priest and theologian Cornelius Loos as patronus sagarum who was forced to revoke his sceptical thesis about the reality of witchcraft in 1593. According to Delrio, Loos then relapsed into this heresy twice (Voltmer forthcoming).

22 For example, the Inquisition condemned the "fearsome Wizard-Priest: Don Guglielmo Campana" (1517) as heretic to lifelong imprisonment in the city of Modena as prison. However, the Apostolic Penitentiary absolved the priest of all his errors (Duni 2007, pp. 85-94).

23 In Trier, its hinterland and in the nearby ecclesiastical territory of Saint Maximin, canons, parish priests, and abbots were denounced as witches. We know about the execution of at least three parish priests $(1589,1592)$. One canon died at the stake (1592), two in custody. The episcopal fiscal was executed or died in custody. Some escaped, many others were suspected, but not accused in a formal trial. Even the provost of the Cathedral chapter was denounced as a witch (Voltmer 2001).

24 Delrio drew his cases from actual witchcraft trials in using the network of the Jesuits and the republique des lettres. He referred to Dietrich Flade, the former bailiff and judge from Trier (executed 19 September 1589), the so-called werewolf Peter Stump (executed in 1589 near Cologne), and to the Pappenheim family (executed 1600 in Munich). From Binsfeld, Delrio cited more than once the story of Hans Cuno Meisenbein, a prominent boy-witch from Saint Maximin (near Trier), and his mother Anna, a female head of the witches' sabbath (Voltmer 2016, pp. 219-26). 
The Compendium Maleficarum, compiled by the Ambrosian monk Francesco Maria Guazzo and printed in 1608, is one of the last great handbooks of demonology. It relied heavily on Grillando, Binsfeld, Rémy (who had nothing to say about witch-clerics ${ }^{25}$ ), and Delrio. In contrast to Bodin, Binsfeld, and Delrio, Guazzo had participated in a witchcraft trial. John of Lank, an elderly priest from a small village in the archdiocese of Cologne, was charged with having bewitched the insane and childless Duke John. The priest committed suicide in prison with Guazzo claiming in his Compendium Maleficarum that he had seen John's corpse while it was still warm (Voltmer 2018a, p. 429).

In 1609, the French judge Pierre de Lancre led a commission to conduct witch trials in the Basque Lands of Labourd. In his apologetic treatise, first published in 1612, de Lancre dealt in length with the topic of the devil's clergy with reference to the Gaufridy-case. He claimed that he had interrogated twelve witch-priests, with at least three of them condemned to death at the stake for witchcraft. With those freshly won confessions from actual trials, de Lancre bolstered his argument that witchcraft happened to be the most prominent crime of the satanic infested priesthood, whose members as heads of the witches' sabbath led their flock to black masses and fornication (de Lancre 2006, pp. xxx-xxxvi, 4, 59-60, 83, 95, 136, 148, 160-61, 192-194, 206, and more often). ${ }^{26}$

In 1609/1610, two nuns of an Ursuline convent in Aix-en-Provence accused the parish priest Louis Gaufridy of having harmed them with diabolic possession. Whereas the exorcism, applied at first by a Jesuit Father, showed no effect upon the possessed, the called in Dominican inquisitor Sebastian Michaëlis, an expert in witch-hunting, was able to conquer the demons, and to charge the suspected cleric. Gaufridy was executed in 1611. With Michaëlis' tracts on exorcism and witchcraft, the fate of Gaufridy gained a prominent place in the sample of narratives about the devil's clergy. These tracts gave advice on how members of the reformed Catholic Church must battle these horrible super-witches (Ferber 2004, pp. 70-88; Walker and Dickerman 2001). The case of Gaufridy reveals the clerical infighting between the Dominican Michaëlis as agent of post-Tridentine Catholic reform on the one side, and the beneficed secular priest as symbol for the old corrupted church on the other side. Insofar, the trial "was part of a campaign for internal church reform" (Spence 2009). The Gaufridy case provides, furthermore, a striking example of the well-known rivalry between the Jesuits and the Mendicant order, this time claiming the victory for the Dominicans. ${ }^{27}$ In its French, German, and English afterlife, Gaufridy (one may say, a reborn Theophilus) appeared as a Faust-figure, a labelling, which had already happened during his trial (Maus de Rolley 2016). ${ }^{28}$

The 'convent cases' in Lille, Loudon, or Louviers virtually copied the Gaufridy-case. In Lille, again Sebastien Michaëlis was invited to exorcise the possessed nuns. This time the accused canon Jean Leduc was declared innocent in 1614, after the papal nuncio and the Holy Office had intervened (Roelants and Vanysacker 2005, p. 778; Po-Chia Hsia 2005, pp. 155-56; Decker 2008, pp. 114-16).

25 In the city of Toul, a cleric was tried for witchcraft in 1617. In the French speaking-parts of Lorraine, we know about one parish priest, Dominique Gordet from Vomécourt, being charged with witchcraft (1630). It remains unclear if he was executed. In 1631, the wealthy canon Melchior de la Vallée, with close ties to the ducal house of Lorraine, was burnt as a witch at the stake, condemned during a political trial: The priest-witch was thought not to have baptised the later duke's wife properly. The duke's marriage thus was invalid and ready to be annulled (Briggs 2007, pp. 188-89, 364-65; Monter 2007, pp. 113-15).

26 The prominent "teen wolf" Jean Grenier claimed to be the son of a priest (Voltmer 2015, pp. 162, 167; Machielsen 2019) —In addition to the examples provided by De Lancre and the convent cases, in Normandy (1598-1647) at least six priest-sorcerers were executed, one was given a life sentence in the galleys, and some more were banished from the kingdom of France. In Provence, (1598-1625) two priests were hanged, two others sentenced to the galleys because of sacrilegious magic. In Paris (1604-1609) four Catholic clerics were executed, in Grenoble a Franciscan friar was hanged (1606), and Dijon saw the hanging of two priests $(1613,1625)$. In Rouen, between 1594 and 1620, over twenty priests had to stand trial because of forbidden magic, and five of them were sentenced to death. During the $1640 \mathrm{~s}$, in Brittany two priests were executed under the same accusation (Monter 1997, pp. 582-83; 2002, pp. 42-43).

27 For the long-standing rivalry between the Mendicant orders and the Jesuits see for example (Stolarski 2011; Tronu 2015).

28 Whereas the Gaufridy case proved to Catholics the need of post-Tridentine reform, to Protestants it revealed the wickedness of popish clerics who were in the devil's snare. The Swiss reformed minister Bartholomäus Anhorn († 1700), who believed in the realities of witchcraft and wrote a warning concerning its dangers, was still repeating the Gaufridy-case in his Magiologia (printed 1674) (Brunold-Bigler 2003, pp. 42-43, 125, 313). In addition, the story of the French priest-witch was translated into English pamphlets and at least in one ballad (Maus de Rolley 2016). 
The cases of the two other clerics, accused of witchcraft by seemingly possessed nuns, ended with deadly consequences, however: Urbain Grandier was burnt alive as a sorcerer-priest in 1634 and Thomas Boullé was burnt in 1647, together with the bones of Father Mathurin Picard, deceased but still accused of witchcraft (Ferber 2004, pp. 89-112). Another convent case occurred in the duchy of Modena (1636) with the most notable religious house in the town infested with demonic possession. Under the exorcisms, performed by five secular priests, the possessed nuns accused the former father confessor Fra Angelo Bellacappa as the witch, who had caused their harm. However, the Congregation of the Holy office in Rome "dismissed witchcraft charges and blamed the exorcists for much of the panic". (Watt 2007, p. 129; 2009). In France, the cases about female possession, exorcisms, sorcery-priests, or witch-nuns found a wide echo in the media, especially during the confessional debates between Catholics, Huguenots (Calvinists), and Lutherans (Blackwell 2000; Levack 2013, pp. 176-77, 194-95; Del Olmo 2018). Probably the last Catholic witch-priest was executed after a most cruel procedure in Silesia in 1684; he still was accused of lechery and devil's baptism (Lambrecht 1995, p. 30).

\subsection{The Relevance of the Priest-Witch and the Devil's (Re-)Baptism}

At the latest since the 15th century and in Catholic demonology, the witch-priest played a prominent role as a (presumed) ringleader of the witches' sect. Actual trials seemingly proved the menacing reality of diabolic priest-witches who presided over the witches' sabbath, conducted black masses, misused sacramental powers and baptised children to the devil. The figure of the witch-cleric served well the urge to promote witch-hunting, demanded in political demonology (Pearl 1999). Its first major promoter was the Spanish Jesuit Juan Maldonado, together with his spiritual followers Pierre de Lancre, Paul Crespet, Jean Boucher, and-implicitly-Peter Binsfeld. Jean Bodin argued in a similar vein. Martin Delrio included Maldonado's apocalyptic attack against heretics and witches in the prologue of his own Disquisitiones. It seems noteworthy that since 1453 with the case of Guillaume Adeline the devil's cleric and patronus sagarum was not a mere theoretical problem, but a fact, proved in a few but prominent actual witchcraft trials. Political demonologists legitimated extensive witch-hunting across all boundaries of age, gender, and status. In following their call, princes, magistrates, and judges were obliged to establish a godly state (Voltmer 2015, pp. 163-68). They should declare war against the enemies of God, against witches, Anabaptist, heretics, adulterers, dissenters, and deviant people of all kinds, seen as the disorderly 'others' who must be disciplined to the fullest extent of the law-and the witch-priest was thought to be the most horrible acolyte of the devil, charging the fortresses of the Catholic Church from within. In appearance, the devil's clergy acted as pious men of the cloth, but they infested the body politic with sin, causing spiritual and corporeal death. These wolves in sheep's clothing had to be picked out to avoid the satanic infiltration of the whole body of Christian society. Jesuits like Father Johannes David from Courtrai promoted around 1600 these anxieties in labelling the sorcerer-cleric as the evilest witch (Roelants and Vanysacker 2005, p. 790). During his mission campaigns in Brittany (1631-1650), Father Jules Maunoir, relying on his fellow-Jesuit Martín Delrio, still was looking for the witches' crime. His questioning found confessions about the witches' gathering, where local parish priests had allegedly played a leading role (Lebec 1997, pp. 10, 130-31, 139, 165).

Since the advent of the Reformation and the Anabaptists, anxieties about false baptism and re-baptism fueled the demonological discourse (Waite 2007, pp. 98-102; 2012). To Martín Delrio and other campaigners of counter-Reformation, "the priests' control over the supernatural realm through the sacraments" (Waite 2007, p. 99) had to be reinforced, because Anabaptist, Calvinist, and witches abused the Catholic Church's sacraments and sacramentals. In fighting off the Anabaptists, any form of re-baptism, thus, was labelled as heretical, blasphemous, and diabolic. For demonologists the devil performed the re-baptism in scratching away the chrism, giving the acolyte a new name, and marking him or her with the devil's mark (Waite 2007, p. 100; Spence 2009). The demonization of re-baptism amalgamated with anxieties about midwives and priest-witches, who performed the infant's baptism falsely in the devil's name, which, however, did not include either the consecration into witchcraft or making a pact with the devil. Such a false baptism left infants outside Christianity 
without any armament against the fiend. Catholic theology had to find a way out of the dilemma, because post-Tridentine dogma forbade any re-baptism as heretical. Thus, false baptism was marked as a defect and invalid performed sacrament. Another baptism could be performed sub conditione. ${ }^{29}$ However, a witch, who had renounced her or his baptism in making a pact with the devil, could not be baptised anew, because this would have meant re-baptism. In conclusion, a proper baptism left a mark on the human soul, which even the devil could not remove (Waite 2007, p. 101-2; 2012).

According to demonology, it happened to be the parents, mostly the mothers, or other witches who consecrated children to Satan at their sabbath. During many trials, child-witches confessed that their mothers or old hags had brought them to the witches' gathering to play the music or to be dedicated to the devil or married to a demon (Voltmer 2016). Sometimes these children-according to the trial records-lacked a proper baptism. Hans Morhaupt from Bamberg received his Teufelstaufe (consecration to the devil) from the female ringleader at the witches' sabbath. A witch-canon was present-but he had nothing to do with this kind of 'baptism' (Gehm 2000, pp. 138-42). A clear distinction between improper baptism, the consecration to witchcraft, and the Devil's re-baptism blurred in popular and demonological thinking. Two further points have to be taken into account: First, the discussion about the post-Tridentine dogma of liberum arbitrium (the free will), according to which a Christian always and almost had the possibility either to withstand the devil's seduction or to subdue voluntarily to Satan (Fuchs 2019). In theology, therefore, the improper devil's baptism, performed by a witch-cleric or a midwife, was a step in the wrong direction, but it did not ultimately hand over the human soul to the devil. Secondly, discussion aroused whether a Christian could ever revoke the eternal bound God had made with him or her by baptism. For example, in 1684 and to quieten a witch panic in Calw (duchy of Württemberg), the faculty of theology in Tübingen stated that God would never dissolute the covenant, made by baptism. Even a full renouncement of baptism, made by a witch, with the grace of God was irrelevant (Weber 1996, pp. 26-27). It still needs discussion how the popular and learned trans-confessional discourse about false baptism, the consecration to Satan at the witches' sabbath, the devil's re-baptism, the liberum arbitrium dogma and the Godly covenant of grace made by a proper baptism emerged and changed in the period of witch-hunting. The link between the demonization of the Anabaptists and the devil's re-baptism at the witches' sabbath is obvious since the lucid studies of Gary K. Waite. In Protestant media, these diversities and differences between the invalid devil's baptism, administered by midwives and witch-clerics, the consecration to the devil by parents and other witches, and the devil's re-baptism were smoothed away to invoke anxieties about the devil's clergy coming originally from popish lands.

In comparing the omnipresence of the witch-priest in demonology with the rather small quantity of trials all over Europe, the two-folded quality of the clerical 'super-witch' has to be emphasized: Firstly, because of the baptism of the flock to the devil, it needed only one priest-witch to lead a community or region in the devil's snare. Secondly, apart from the lecherous and superstitious sorcerer-priest, the clerical patroni sagarum were labelled as the most dangerous witches, who questioned the reality of the witches' crimes, who helped the accused, and who brought to daylight the cruel procedures of trial and torture. Patroni sagarum thus exacerbated the allegedly sacred work of witch-hunting. Massive witch-hunting seemed to be necessary to defeat these empowered devil's minions, either to unmask the witch-priest or to detect the other (male and rich) members of his diabolic flock. ${ }^{30}$

29 After the Council of Trent and in battling the heretical sect of Anabaptist, baptism could only be performed once. In obscure cases, a valid baptism was administered under the condition (sub conditione) that the first one had been invalid, for example if a midwife had performed an emergency baptism with unclean water, or if a priest or a minister had not used the proper ritual, or had baptised (allegedly) in the devil's name-For Lutheran discussions of re-baptism and baptism sub conditione see (Rowlands 2019, pp. 18-9; Hill 2015; Seebaß 1966).

30 For example, in the city of Trier, the denunciations of two already convicted witch-priests were needed to overpower Dietrich Flade, the prominent and wealthiest member of the urban elite. In the course of the Jean del Vaulx case, a great witch-hunt occurred in the territory of Stablo-Malmedy. 


\section{The Printed Media—Confessional Debates}

\subsection{Witch-Priests, Jesuit-Witches, Patroni Sagarum, and the Trier "Superhunt"}

The role of the media in transmitting and mixing elite and popular ideas about both demonology and witchcraft has recently been emphasized (Voltmer 2020; 2017a). The discourse about magic, witchcraft, and sorcery left its trace in almost every genre of historical source material, whether text or image. $^{31}$ The reception of printed media, however, changed in the differing historical, social, legal, cultural, and political contexts. ${ }^{32}$ The narrative of the witch-cleric claimed a prominent place in the discourse. In the printed media, the figure started a career in 1575, when Ruprecht Rambsauer, parish priest in Bramberg (Salzburg), and his concubine were executed at the stake, after both had been charged with witchcraft (Schwillus 1992, pp. 288-337; Rowlands 2019, pp. 5-6). ${ }^{33}$ The surviving trial records and the pamphlet, which promoted the case to the public, have little in common, however. Apart from trials targeting clerical necromancers in Italy or Spain, Rambsauer seems to be one of the first ordained priests executed as diabolic witch after the Italian Mirandola trials in 1522/1523 and after the cases concerning banished, incarcerated, or relegated priest-witches provided by Grillando. In the pamphlet, the story about the devil's priest and his concubine unfolds in a literary style, with Rambsauer denying the baptising of children in the name of the devil but negotiating with the fiend about a proper price for performing weather magic. The pamphlet was printed in Vienna; it thus stemmed from a Catholic background. No confessional polemics can be detected in it, but it evoked the interest of Johann Jakob Wick, Protestant preacher and minister in Zürich who included the pamphlet in his collection of printed news. ${ }^{34}$

Obviously, the narrative about Catholic priest-witches executed as blasphemous heretics suited Lutheran and Calvinist parties well in their polemical debates. The discourse about Catholic witch-clerics interlinked with polemics against the Jesuit order. In the year of Rambsauer's execution, a Lutheran preacher declared Jesuits as an evil sect of sorcerers (Janssen 1910, p. 457). A pamphlet, stemming from a Lutheran milieu took up the propaganda in 1579 and told sensational faked news from Dillingen where a Jesuit had been put on trial because of witchcraft and murder with his fate still unknown (Paintner 2011, pp. 427-32). Allegedly, the Jesuit had made a pact with the devil, and had learnt the occult art from an old witch to conjure several tempests to take vengeance on his enemies, the Lutherans. The weather catastrophes thus struck only Lutheran lands. This shocking news got as far as Pomerania, where a Lutheran noble noted it in his private diary (Janssen 1910, p. 457). The narrative about Jesuits as the natural born allies of Satan was elaborated during the confessional debates of the 16th century. Polemics defamed the order as a sect or a conspiracy, which aimed at nothing less than global tyranny. ${ }^{35}$ In 1595, a pamphlet propagated the news that Jesuits had turned the crime of heresy into the crime of witchcraft to instigate false trials against wealthy men. For this purpose, they wrongly accused the rich of having won their fortune with the devil's help. In using the denunciations of deluded old women, the Jesuits allegedly called for rapid procedure, harsh torture, and a major share of the confiscated money to fill their pockets (Janssen 1910, p. 455). ${ }^{36}$ The Lutheran minister Melchior

31 "Rita Voltmer points out that overall explanations have to consider a daunting variety of historical sources, including: manuscripts, printed tracts, decrees and proclamations, trial records, newspapers, pamphlets, learned treatises, fictional literature, poetry, travel accounts, chronicles, plays, songs, encyclopedias, almanacs, planetary books, polemical literature, sermons, and more. Each genre presents its own unique challenges." (Robisheaux 2018, p. 1).

32 A survey concerning witchcraft and witch trials in the European media, yet, has to be written; recent studies are: (Voltmer 2020, 2010b; Warfield 2017; Behringer 2009; Gibson 2006, 1999).

33 Rambsauer had fallen prey to a trial because of his concubine, who at first had been accused and because he had tried to defend her.

34 The "Wickiana" is a 24 volumed collection of broadsheets, pamphlets, prints, handwritten texts, and drawings from the 16th century.

35 For the long-standing history of religious propaganda and anti-Jesuit polemics see in general (Waite 2013, pp. 493-95; Worcester).

36 Anonymus author, Wahre abconterfeyung/der schädlichen und erschröcklichen Sect der Jesuiter/mit angehenckter warnung/andie löbliche teutsche Nation/sich vor irer vorborgnen list/und gifft zu hüten, 1595, pp. 25-26; see (Paintner 2011, pp. 362-70). 
Leonhard claimed in 1599 that Jews, witches, and Jesuits all belonged to the same vermin. In a sermon, he stated that Jesuits "are very apt to interest themselves in witches and sorcerers and to be full of mercy towards this devil's crew, for no other reason than that they hope thereby to escape falling themselves into the hands of the torturer." (Janssen 1910, pp. 460-61). Libelli famosi defamed even leading Fathers of the society as Pierre Coton or Robert Bellarmin as sorcerers, sodomists, or fornicators (Paintner 2011, pp. 338-49; Franz 1980). The concept of Jesuits as patroni sagarum was thus born before the turn of the century. It labelled the Societas Jesu as a secret conspiracy of heretics. The open enemies of the order (Protestants as well as Jansenists) blackened the Jesuits' schools and seminaries as nurseries of witchcraft and sorcery. The fictitious polemics and paper wars interacted with facts, because from the first third of the 17th century, pupils of the order were denounced as witches. In the schools, hysterical accusations spread, causing the Society to implement severe orders to stop the rumors. In Würzburg, at least five seminarians were burnt at the stake and some were held in custody for nearly two years. In the long run, the polemical narratives about the Jesuits being instigators of witch trials, patroni sagarum, and sorcerers themselves were rooted in the Trier witch-hunts, where the Jesuits together with the suffragan bishop Peter Binsfeld had given children and juveniles a prominent role as accusers in trials against high ranking men and clerics (Voltmer 2016).

Accusations against priests and canons arose at the latest from the 1589s onwards during the exceptional witch-hunts in the city of Trier, its surrounding districts, and in the nearby territory of the Imperial abbey of Saint Maximin. ${ }^{37}$ Here, the figure of the priest-witch finally gained a prominent position both in confessional debates and in anxieties, transmitted through the networks of Catholic clergy (Voltmer 2001, 2003). In 1589, two parish priests were executed as witches. They had denounced Dr Dietrich Flade, a judge in the electorate's High court and the most wealthy and powerful man in the city of Trier, as their accomplice. A high-ranking canon of the College of St Simeon, who held the office of a sealer of the ecclesiastical court, likewise, was denounced as a witch. He fled to avoid a trial. In 1592, another parish priest and a canon of St Simeon were killed at the stake. It is noteworthy that Peter Binsfeld held the office of provost in the College of St Simeon. In March 1593, the Dutch exile and theologian Cornelius Loos, who lived and taught at the Benedictine Imperial abbey of St Maximin near Trier, had to stand before an ecclesiastical tribunal to renounce his heretical arguments, written against the Trier witch-hunts (Voltmer 2001, forthcoming). ${ }^{38}$ The papal nuncio Frangipani feared that the never printed book of Loos would have troubled the maintenance of Catholic Church. In December 1593, Frangipani reported to the Pope about the multiplying witches' sect in the archdiocese of Trier, where even the provost and canons of the Cathedral chapter had fallen under suspicion of witchcraft. The noble court of the prince elector, likewise, was thought to be infested. Between the lines, the nuncio evoked the fear that with the reigning prince elector being a sick man, who might die at any moment, the diabolically infiltrated Cathedral chapter might vote for a new archbishop, who himself secretly belonged to the devil's sect, threatening the safety of the whole archdiocese. The Trier witch-hunts thus won a dubious reputation, inter alia with the tract of Peter Binsfeld (Tractatus de confessionibus maleficorum et sagarum), published firstly in 1589 in Latin, and appearing in two German translations in

37 A register from between 1586 and 1594 lists the names of 1300 women and men from Trier and the territory of St Maximin, who had been denounced as witches; it includes about 40 clerics (friars, monks, canons, and parish priests), mostly from the city of Trier (Muschiol 2004, pp. 84-85; Voltmer and Weisenstein 1996, pp. 313-81).

38 Martin Delrio published the recantation in his handbook Disquisitiones magicarum and defamed Loos as patronus sagarum The similarities between Guillaume Adeline and Cornelius Loos are obvious. The fate of both so-called protectors of witches would have fallen into oblivion, had it not been for the fact that their adversaries-Jacquier and Delrio-included the triumph over the fellow-clerics in their respective tracts. 
1590 (Trier) and twice in 1591/1592 (Munich). ${ }^{39}$ The impact of the Jesuits, involved in detecting canons and parish priests as witches, seems obvious.

As early as 1589 news about the "first superhunt" (Monter 2002, p. 23) in Trier circulated in the printed media. The Fugger handwritten newsletter passed on probably for the first time the information that in the lands of Trier a group of priest's housekeepers (in the meaning of concubines) had been executed. In Cologne, the Austrian nobleman Michael Aitzinger published his first news journal, including horrible stories from the Trier electorate, where Dietrich Flade had been executed as a witch to scare off any other member of the witches' diabolic conspiracy (Voltmer 2010b, pp. 124-25; Behringer 2009, p. 229). The reporter added a vital piece of information: Many clerics were suspected as witches, including two parish priests, who had administered pastoral care. Probably lacking more detail, he reported that the two priests were degraded, but said nothing about their execution. The printer Nicolaus Schreiber (Cologne) published at least two pamphlets in 1589 and one in 1594, listing witchcraft trials all over Germany, including the prominent cases of Flade and of the so-called werewolf Peter Stump. Schreiber did not mention a witch-cleric. However, I assume that since a lost pamphlet had circulated which added the example of a witch-cleric to the narratives about Flade and Stump. It was translated from German into Dutch in 1589, and in 1591 into Danish (Voltmer 2017a, p. 17; 2017b, pp. 127-28). ${ }^{40}$ Both pamphlets told the story of a priest from a village nearby Trier-presumably from the vicinity of St Maximin — who had denounced his faith face-to face to a female demon, with whom he committed lechery. He was executed as a witch after his degradation. There can be little doubt that both pamphlets transmitted the idea of Catholic lands being infested with lecherous werewolves, diabolic magistrates, and blasphemous witch-priests into predominantly Protestant regions. The news about witch-priests from Trier and Maximin thus spread rapidly, and was noted down in diaries, journals, chronicles, and newsletters. ${ }^{41}$

During the witch trials in Trier, a certain Father Paulus, called the rector of the Jesuits, was denounced once as a witch in 1592. Since such a person did not exist, it had no consequences at all. In 1596, the Jesuits' annual report (litterae annuae) told the story of a man accused of witchcraft who had named members of the order and of the criminal court in Trier as accomplices. To avoid further witchcraft trials, the Jesuits allegedly persuaded the man to revoke his allegations, but despite their intercessions, he was executed. This narrative has not left any trace in the archive, and therefore it should be treated with the greatest methodological care (Voltmer 2001, pp. 103-4). In 1629, the high court of St Maximin asked three Jesuits from Trier to write a theological opinion concerning a man from St Maximin who had confessed to sodomy and witchcraft. The Fathers did not show any anti-demonological thinking in their three opinions which still relied inter alia on Martin Delrio. They advocated execution rather than mercy (Sobiech 2019).

The Protestant faction commented eagerly on the news coming from popish lands. The Hessian superintendent Georg Nigrinus, a personal enemy of the Jesuits, in his translation of Goedelmann's sceptic tract (1592), accused the witch-hunting prince bishops as the worst of sorcerers, because as fanatical persecutors they burnt many innocent people together with indeed real witches, of whose presence Nigrinus was convinced. Blinded by Satan, these ecclesiastical princes were unable to recognize the Lutheran confession to be the true Christian faith. On the contrary, these eager

39 The treatise saw two extended versions in Latin (1591, 1596, followed by reprints); in 1591, Binsfeld published his second treatise on witchcraft, magic, and superstition the Commentarius in titulum codicis lib. 9 de maleficis $\mathcal{E}$ mathematicis of the Justinian code, as an appendix to his revised De confessionibus. In reaction to the sceptical arguments of Cornelius Loos, Binsfeld published a considerable expanded version of the Commentarius in 1596, again as an appendix. His plan of publishing it as a third revised book of its own never came to fruition (Voltmer forthcoming) - On the cover illustration of the Bavarian print, one of the witches, dressed as a wealthy bourgeois woman, is paying homage to the devil, probably disguised as a cleric. The figure is clothed in a long cassock with a white collar, carrying a goblet or chalice in one hand.

40 The pamphlet's importance in the context of the Danish witchcraft trials is discussed by (Kallestrup 2018, pp. 140-42).

41 For example: Fugger trading company (Nurenberg, 1589), Hermann Weinsberg (magistrate in Cologne, 1589), Martin Klöckner (merchant in Paderborn, 1589), Peter Cratepolius (Franciscan friar in Cologne, 1592), Johannes Reckschenkel (Carthusian monk in Cologne, 1598) (Voltmer 2003, pp. 242, 251-57; 2010b, pp. 124-26). 
ecclesiastical witch-hunters tried to prove their wrongdoing as right in prosecuting Protestants as heretics, and witches as enemies of God, not realizing that they were shedding innocent blood on both sides (Voltmer 2020). Around 1600 (and printed twice in 1604/1605), the Lutheran preacher David Meder promoted the battle against witchcraft and popish superstition (Schulte 2009, pp. 131-34). With similar arguments, he mentioned the horrible witch-hunts in Catholic territories (Trier, Mainz, Cologne) to prove that the devil targeted mostly the superstitious papists who did not follow the true Lutheran faith. Meder enumerated the examples of wizard-monks and priest-sorcerers, executed in abundance. He referred to pamphlets from Trier and Cologne, which contained stories about wicked witch-priests: Wizard-monks from Trier had misused confession to detect witches and to lure these women into even more diabolic services; two witch-priests from Cologne had baptised with a Latin formula more than 300 children in the name of Satan (Voltmer 2020; Meder 1605, fol. 37v-38, 46). Meder had seemingly exaggerated his polemical argument, since regional studies have not found any evidence about an executed witch-cleric in the electorate of Mainz. However, even in Mainz, anxieties about priest-witches surfaced: In 1593, a certain canon from Aschaffenburg had trouble defending himself against an accusation (Pohl 1998, p. 222). ${ }^{42}$

Probably the greatest impact in confessional debates about the devil's clergy made a broadsheet, called the Trier witches' sabbath, published on its own or together with a tract (printed twice in 1593, once in 1594 and probably in 1603). Both promoted the horrible news that Satan had erected his realm in the archdiocese of Trier. My close reading and decoding of the iconography of the image allows the suggestion that the author of the tract, Thomas Siegfrid, and the anonymous engraver stemmed from a Protestant milieu. Both used the topic of a Catholic major hunt to declare witchcraft as a horrid crime related directly to popery and performed most notably by members of the Catholic elite, monks, nuns, and clergy. According to the figures in the image, the latter practiced ritual magic and sorcery, whilst according to the Calvinist Siegfrid, Catholic men of the cloth had always been the worst sorcerers. Siegfrid, moreover, had drawn the examples of diabolic priests from Bodin. The message was clear: Protestants, as the true Christians, should not fear diabolic attacks or witchcraft (Voltmer 2010b). The Calvinist minister and member of the consistory in the Palatinate, Marcus zum Lamm, included the broadsheet in his 33 volumed collection of news, leaflets, and pictures. The witchcraft news bolstered his Protestant worldview:

"This horrible sorcery and diabolic witchcraft happened some years ago in the electorate of Trier and its surroundings, where a priest had been unmasked who had baptised the children in the devil's name and who had enacted many unspeakable abominations. These are the strong errors, marvelous fruits and powers of darkness routed in pagan popedom. The bishop of Trier ordered the execution of all inhabitants of a village, men and women, except three innocent women, together with the priest who had baptised more than 100 children in the devil's name." 43

The discourse about the witch-hunts in the electorate and city of Trier as well as in the territory of St Maximin focused on the fact that they had transgressed any boundaries of gender, age, and status. Protestant polemics as well as Catholic anxieties emerged around the figure of the witch-priest, baptising generation upon generation to the devil, and symbolizing the horrors of a Christian society infested with evil from within. The battle of the post-Tridentine Church together with its strike force, the Jesuits, against heresy, superstition, necromancy, and witchcraft appeared as a life and soul saving attempt. The examples of Guillaume Adeline, Johannes Wier, Johannes Goedelmann, or Cornelius

42 The pamphlets described by Meder, so far, are unknown. Trial records or other source material concerning the presumed monk-wizards in Trier or priest-witches in Cologne, who were accused of devil's baptism in the 16th century, have not survived. However, Meder's narratives might not have been mere inventions, since in 1617 the faculty of theology at the university in Mainz delivered a legal opinion on how to deal with two priest-witches, who had baptised in the name of Satan (Pohl 1998, p. 152; Sobiech 2019).

43 I have slightly abridged the comment of Marcus zum Lamm; see (Harms 1985, p. 316). 
Loos have shown that any critic of witch-persecution was labelled with almost deadly consequence as patronus sagarum, whichever confessional faction he came from and whether he was a cleric himself or not.

Around 1600 the tide though slowly began to shift. In Bavaria, the party of zealous witch-hunters lost influence at the court with their political adversaries blocking any further major witch persecutions (Behringer 1997). However, whereas Protestants could link their sceptical views on massive witch-hunting with defamations against Jesuits, ecclesiastical prince electors, and in general, against papists, it remained difficult for Catholics to utter any harsh criticism after the recantation of Loos. Catholic clerics, notably, had to be very cautious with their arguments. Clerics, canons, and priests were members of an European-wide network, built up through shared education, benefices, friendship, and (noble) family ties. With the help of correspondence, they were well informed about the massive assault against their status group. Likewise, the Jesuits were tied together in their own global network of education, training, studying, travelling, and exchanging information in letters and reports. None of the clerical status groups developed a homogenous attitude concerning witchcraft and its persecution. In the Jesuit order, there existed on the one hand a majority of eager promotors of witch-hunting. On the other hand, a minority of Fathers developed a growing scepticism concerning trials, denunciations, and torture. Some Fathers underwent their conversion in the dungeons, facing daily the unspeakable horror of human misery.

Polemical Protestant pamphlets defamed Jesuits as patroni sagarum. With a similar attitude the Jesuit Martin Delrio, master of demonology, labelled Flade a 'patron of witches' to explain why a sacrosanct judge such as Flade was charged with witchcraft himself. ${ }^{44}$ We can assume a similar labeling approach in cases of so-called witch-clerics, since the role model patronus sagarum provided a legitimation for degrading and executing ordained priests as witches. The mere label, however, is not evidence enough to prove that all witch-clerics harbored sceptical thinking.

In 1603, however, a prophecy appeared which from a Catholic perspective provided both a defence of the Jesuits, and of the witch-clerics (Janssen 1910, pp. 443-44). ${ }^{45}$ The author, claiming to be an eyewitness, lamented that in many places the witch-hunts had forced people to avoid Catholic mass as well as any open demonstration of piety or devotion, "because otherwise they might easily fall under the charge of sorcery." (Janssen 1910, p. 443) The same suspicion would befall pious priests who did not dare to offer the Holy Sacrifice every day, but to do it in secret. Such pretences remained necessary, because witches were believed to mask themselves as devout people, visiting the Holy Mass as often as possible to steal the Host for their evil sorcery. The author called these superstitions "a craze beyond all crazes". Furthermore, he praised the Jesuits who ministered in the prisons, hearing confessions and bringing consolation. The anonymous author uttered no disbelief in witchcraft, but he criticized major witch-hunting, especially in ecclesiastical territories like the electorate of Trier, whose prelates had not restrained the trial procedure done by cruel secular witch-hunters. Even the clergy did not intervene, "for if they speak they are themselves in danger of the rack, as experience has sufficiently shown, especially in the archdiocese of Treves, where they have burnt alive as sorcerers by sentence of the judges" (Janssen 1910, p. 444). The pamphlet corresponds with news from the Jesuits' annual report (1601) about the people rejoicing at the end of witchcraft persecution, because by now they were able to approach the sacraments without falling into suspicion of being witches (Janssen 1910, p. 442). The set of arguments stemmed certainly from a Catholic, possibly a cleric, maybe even a Jesuit. The pamphlet labelled witch-priests, indeed, as patroni sagarum, but in the full sense of a positive meaning: According to this narrative, none of the executed priests in Trier had been a witch, but on the contrary, they

44 Outdated research had taken this verdict for truth, modelling Flade into a critic of witch-hunting. Yet archival evidence shows that he had been no heroic opponent of the witch trials. On the contrary, he had presided over at least eight witch trials (1577-1588), in which he tried to force the accused women to confess (Voltmer 2001, pp. 77-85; 2003, pp. 251-57).

45 Witchcraft research has missed this very important pamphlet. So far, the original print is lost. We rely on the few sentences to which Janssen referred. 
were adversaries to cruel witchcraft trials, and therefore had been suspected to be the devil's minions. However, since the trial records of executed priest-witches from the electorate of Trier and St Maximin are lost, this specific labelling cannot be cross-checked with additional source material. The anonymous author was shocked, because the high prelates had allowed secular jurists (witch commissioners!) to conduct cruel trials against clerics. Religious princes had not listened to the warnings of their fellow clerics, nor had these princes protected the clergy against false witchcraft accusations and murderous executions. As far as we know, until the Cautio Criminalis in 1631 no other pamphlet or tract discussed these arguments.

\subsection{Witch-Priests in Swabia, Franconia, and Cologne}

The "Trier superhunt" ended around 1596. The second phase of witch-hunting (during the first third of the 17th century) in the electorate of Trier and its surroundings never gained any public attention, mostly because no pamphlet provided sensational news about it. Instead, the prosecution in the prince-priory of Ellwangen (1611-1618) under its provost Johann Christoph of Westerstetten claimed to occupy the first place in publicity. Due to a Protestant pamphlet (1615), the provost had instigated these well-known witch persecutions without any respect to status, gender, or age. The pamphlet told the story of three witch-priests and an organ-player (who might have had some minor ordination) being executed as witches. In a sensational, polemical way the pamphlet rejoiced in cruel details about the degradation of the culprits before execution. Again, the narratives of baptising in the devil's name activated anxieties (Voltmer 2020; Rowlands 2019, p. 6). Unlike the pamphlets of 1579 and 1595, this one reported indeed facts, since the execution of the clerics had taken place (Mährle 1998, pp. 389, 394-96, 410, 424-25). Probably because the provost Westerstetten encountered difficulties with the Cathedral chapter concerning valid procedure in questions of confiscation, no further cleric had to stand a witchcraft trial in Ellwangen. However, Westerstetten made his career as prince-bishop in Eichstätt, where with the zeal of the counter-reformation and the help of the Jesuits the witch-hunts went on from 1617 to $1631 .{ }^{46}$ Not one pamphlet has survived which commented on prosecutions in this small ecclesiastical territory, but there are testimonies concerning the Jesuits preaching about the devil's baptism (Schwillus 1992, p. 159). The witch-cleric, especially ordained priests and clerics with pastoral care duties, apparently, became one of the main targets. ${ }^{47}$ This intent is revealed in an anonymously and undated Consultum super Crimene Veneficii, written presumably by a legal expert which evaluated the validity of denunciations made by convicted witches. The memorandum included six legal advices concerning clerics under suspicion of witchcraft to quicken their arrest and torture:

1. Denunciations against clerics need no further requirement than those against lay people.

2. In trials against clerics not more denunciations to apply torture are needed than against lay people.

3. In case of crimen excepta, clerics and ordained priests can to be tortured.

4. Clerics shall not be tortured to a lesser extent than lay people.

5. Clerics who administer pastoral care or who are ordained priests have to be arrested and tortured more rapidly than other people, if sufficient evidence is provided.

6. Clerics can be tortured by lay people with the bishop's consent (Schwillus 1992, p. 88).

With the memorandum at hand, and during the ongoing prosecution, more than 40 clerics and canons were denounced as witches, including several high-ranking canons from the Cathedral chapter. The convicted witches from Eichstätt (and its vicinities) with the help of questioning and interrogatories,

46 From 1590 to 1631 (with a peak between 1617 and 1631) at least 260 people, mostly women, suffered execution as witches (Durrant 2007, p. 3).

47 The witchcraft trial against the parish priest Reichard is mentioned only on the margins in (Durrant 2007, pp. 4, 6, 20, 21, 26, $67,77,78,83,182,192,251)$. Durrant neither discussed the denunciations against clerics nor the Consultum, probably because he was unaware of Schwillus' research. 
elaborated colored narratives about the sabbath, including black masses, and desecrations of the host. The princely witch commission was engaged with the preparation of denunciation extracts against some of the denounced witch-clerics. In 1624, Johannes Reichard, an urban and wealthy parish priest, went to jail. His brother and mother had already been executed, the latter because of witchcraft. Of course, Reichard's interrogation and torture included questions concerning the devil's baptism, but he could not be brought to a confession. He died after 20 years in custody. Perhaps the commission had thought to extract from him valid denunciations against his fellow clerics in Eichstätt. However, he remained steadfast, and could not be broken. Perhaps to avoid further trouble, Westerstetten and his commission refrained from hunting down other witch-clerics (Schwillus 1992, pp. 122-203). ${ }^{48}$ Probably two Jesuits Fathers, including the Cathedral preacher, had been denounced as witches, but none of them was tried. These denunciations of Jesuits did not stop the witch-hunting in Eichstätt.

The notorious witch-hunt in the neighbouring prince-bishopric of Bamberg cost the lives of almost 1000 persons, with a peak between 1626 and 1630 with more than 600 victims (Gehm 2000, p. 268). At least three clerics were charged with witchcraft in 1627 and 1628 . The accusation of devil's baptism once more played a vital role (Gehm 2000, pp. 140-41; Schwillus 1992, pp. 208-14). Two clerics suffered degradation and execution. The baptisms of one of them, which he confessed to have done in the name of the devil, had to be performed sub conditione (under condition). The third cleric remained in custody; he won his freedom in 1631. Convicted witches had named at least twelve clerics as their accomplices. Denunciations against priest-witches reached very high-ranking men. According to a letter from Bamberg to a priest in Cologne, the prince bishop himself was denounced as a witch nine times (Schwillus 1992, pp. 207-8). Condemned witches, likewise, named the Cathedral provost together with the suffragan bishop Friedrich Förner as accomplices. To free Förner from any suspicion, the prince bishop himself wrote letters, addressing in November 1628 two high-ranking Jesuits: Wilhelm Larmormain, father confessor of the Emperor, and Adam Contzen, father confessor of the Bavarian duke. The defence of Förner stressed his eager and relentless battle against witchcraft and the devil's machinations in the name of counter-reformation (Smith 2005). Indeed, in his sermons (published in 1625) Förner had emphasized that witches multiplied the most where at first Jews and Protestants had been driven away, because in a final assault Satan tried to conquer the last bulwark of post-Tridentine Catholicism. Catholic princes in general and ecclesiastical authorities in particular had to eradicate the enemies of true religion. In one of his sermons, Förner reported from the witches' confessions, made in 1615, that Satan had seduced them to desecrate the seven sacraments. In the chequered clothing of a heretical preacher, the demon allegedly celebrated a black mass by distributing fiery hosts made of tar and gave inverted sermons at the witches' sabbath. The fiend thus seduced the perverted flock of witches even deeper into the crime of crimes (Förner 2011, p. 73). However, after Förner had been denounced for witchcraft himself, and in the aftermath of this affair, no further executions of priest-witches occurred in Bamberg. ${ }^{49}$

The witch-hunts in the prince bishopric of Würzburg, conducted under the reign of Philipp Adolf of Ehrenberg, achieved the highest death toll of witch-clerics. The dynamics of counter-reformation still played a role, even after the outward process of re-catholisation had ended (Smith 2008). Nevertheless, the canons of Würzburg still lived a non-reformed life with concubines and a noble lifestyle. Whether political or economic reasons took the greatest impact (Rowlands 2019, p. 13), whether the canon's lifestyle caused envy and hatred in the populace, whether the dynamics of questioning produced so many denunciations, these and other factors triggered the persecution from 1627 to 1630 . In the media,

48 (Schwillus 1992, pp. 87-89), links the undated memorandum to Reichard's trial. I presume that the witch-hunting commission planned an assault against witch-clerics and needed the legal opinion in advance. It failed, however, to prove its usefulness in the Reichard case.

49 We do not know who denounced Förner as a witch. (Gehm 2000, pp. 169-72), argues that these accusations must have stemmed from high-ranking men rather than from convicted witches. Probably Jesuits from Bamberg, who were already voicing warnings against the cruel persecution and helping suspects to escape, had spread the accusations against Förner. However, evidence is missing about this supposed Jesuit anti-witchcraft conspiracy against the witch-persecution. 
the Franconian witch-hunts were perceived as a combined set of actions, ordered by the two prince bishops in Bamberg and Würzburg as allies in their personal Armageddon. At least two pamphlets $(1629 / 1630)$ were printed, claiming to be published on orders of the respective bishops and chapters. Both texts lamented about the evil deeds of the witch-clerics. Close reading and contextualization, however, provide good argument that both pamphlets were the products of a Protestant milieu. They belong to a sample of at least eight pamphlets dealing with the witch prosecutions in Franconia. With one voice, they repeated the message of diabolic witchcraft infesting the lands of ecclesiastical princes, and popedom in general (Voltmer 2020). The narrative about the devil's baptising played its well-known role, this time further sensationalised with an alleged baptismal formula and the news about monks and priests being executed as witches. However, neither in Würzburg nor in Bamberg did monks or friars fall prey to the witch trials. According to Schwillus, the surviving records from the witchcraft trials against canons have nothing to say about baptising in the devil's name. The absence of the devil's baptism results probably from the fact that most canons did not have any duties in pastoral care. However, Protestant media coverage did not respect these details.

Whilst the ecclesiastical princes in Swabia and Franconia allowed massive witch-hunting from 1615 to 1630, on the Mosel and in the northern Eifel territories persecution cumulated either in small ecclesiastical territories such as St Maximin or in minor secular lordships such as Schmidtheim or in the Manderscheid counties (Voltmer 2018b, pp. 35-49). In Westphalia the first execution of a witch-cleric had occurred in $1591 .^{50}$ The hunt for witch-clerics started again probably around 1617, when the Cologne vice-general together with the Jesuits identified a rural parish priest who seemed to be notorious for superstitious actions as well as magical deeds (Sobiech 2019). In the same year, the Mainz faculty of Theology issued an expert opinion, written inter alia by the zealous Jesuit Adam Contzen, on how to deal with two witch-priests. It recommended re-baptism sub conditione which had to be done in any case of an executed witch-priest who had administered pastoral care, and who was thought to have baptised his flock in the name of the devil. ${ }^{51}$

Father Peter Roestius, SJ, the later adversary of Friedrich Spee, demanded the procedure even in the case of a strongly suspected parish priest who in February 1631 was still on the run (Sobiech 2019). ${ }^{52}$ We know for certain that in the case of four executed parish priests from the Eifel, Father Heinrich Rhincopius from Münstereifel, likewise a former colleague of Friedrich Spee, conducted the re-baptisms. ${ }^{53}$ For the Schmidtheim flock, the re-baptism was ordered in July 1630, after Father Kirsbach had been captured and questioned, but was not yet executed. Due to the plague the holy ceremony had to be postponed. Finally, on 21 March 1631 and after catechetical instruction, Father Rhincopius re-baptised 63 men and 82 women in Schmidtheim. Due to the devastating witch-hunts and the plague, the former godfathers and godmothers were mostly missing. Another high cleric and the noble lady of the house acted thus as godfather and godmother. Afterwards, Rhincopius heard the life confessions of the freshly baptised members and performed the sacrament of penance. ${ }^{54}$ Together with sermons, exorcism, theatre, and popular mission, this and similar events belonged to the tools of new post-Tridentine Catholicism, staged dramatically by Jesuits and Capuchins (Rowlands 2019, p. 7; Voltmer 2018b, pp. 21-26; Waite 2013, pp. 493-95; Levack 2013, pp. 88, 97).

I assume that similar to Kirsbach the clerics on the run sought anonymity in the free city of Cologne with its many religious institutions, and with many a chantry priest, vicar, and hireling in

50 See footnote 19.

51 In the case of a witch-priest, it was entirely uncertain when he had started the devil's baptising and whether he had done it properly from time to time. Thus, a re-baptising sub conditione was allowed.

52 Maybe the advice was talking about Peter Cullener or Hilger Trierscheid, two parish priests from the Northern Eifel who were denounced as super-witches. Both had fled to avoid trial and execution. As far as I know, they were never captured.

53 The Kirsbach case remained unknown to Rowlands (2019, p. 7). Her question about the procedure in re-baptising is answered now.

54 The witch-hunts did not end in Schmidtheim with the execution of Kirsbach (17 August 1630); during December 1630 and January 1631, another four women were burnt, followed in March and April 1631 by eleven executions (seven women). After one burning in 1633 (a man) and five in 1635 (women), the prosecution came to an end (Voltmer 2018b, pp. 175-61, chart). 
search of new benefices. In the eyes of Cologne's ecclesiastical prince Ferdinand of Bavaria and his privy council, the magistrate of the free city acted as patroni veneficarum, because they granted many supposed witches shelter and security (Voltmer 2018b, p. 30). The illusion of peace, however, had already been shattered by the execution of Katharina Henot in 1627, denounced as a witch by an apparently possessed nun. A chain of 33 witchcraft trials followed with 24 women executed. ${ }^{55}$ Some clerics in the city, however, asked for more trials. Heinrich Glimbach, canon of St Severin, published a pamphlet (Lamentatio animae suspirantis ad Deum pro exstirpatione magiae) with the beginning year of 1630, lamenting about the holy city of Cologne being beleaguered by and infested with witches. In his fantasy, clergy as well as laity, men and women, old and young, had been seduced into witchcraft. He demanded widespread denunciations and severe punishment. The canon had been inspired by fears about a city-wide conspiracy of witches, whilst he had cared in Winter 1629 as father confessor for Christina Plum, a young girl claiming to be possessed. She accused many members of the urban elite and the high clergy as accomplices, including the suffragan bishop Otto Gereon, who found himself defamed of baptising children into the devil's snare. Furthermore, Plum affirmed that she had seen inter alia a certain Jesuit at the witches' sabbath. Glimbach took her denunciations very seriously, walking her around the Cathedral, where the Jesuits were hearing confessions so that she might point at the wicked Father (Voltmer 2018b, p. 122; Sobiech 2019). However, Christina Plum had to endure another interrogation, held by two more priests, one a Jesuit. Her denunciations were suppressed as fraud, but nonetheless she was burnt as a witch on 16 January 1630. Some members of the high clergy (including Glimbach), who acted on the side of the ecclesiastical juridical administration in the cases of Henot and Plum, had joined in the witchcraft trials against the rural parish priests in the Northern Eifel. Dean Adolf of Pempelfurt, for example, demanded the application of more severe torture in the case of the rural parish priest Matthias Hennes, and most of them had signed the degradation charter of Laurenz Kirsbach (Voltmer 2018b, pp. 120, 122).

\subsection{The Testimony of Heinrich of Schultheiß in 1634-Witch-Priests and Jesuits as Patroni Sagarum}

The exceptional witch-hunts in Bamberg and Würzburg, transgressing borders of age, gender, and status, established an empire-wide critical discourse about its legitimacy, reaching from Franconia to Cologne and Westphalia. I was able to match together some puzzle pieces of this almost forgotten discourse which, apart from oral communication, included secret and open letters, notes in diaries, lists of victims, manifests, pamphlets, and tracts, transmitted partly in the networks of clerics and Jesuits. Ultimately it reached the Diet of the prince electors in 1630, the Imperial Aulic Court and the Imperial Chamber Court, whose verdicts discredited massive witch-hunts and made them almost impossible. During this discourse, the Würzburg authorities had been accused to the wider public in the Old Reich of shedding the blood of innocents, and thus acting like tyrants. The degraded, tortured and executed, or still imprisoned priests and clerics topped the list of these martyrs. Some Jesuits and some members of the secular elite in Bamberg as well as in Würzburg seem to have participated in this discourse, seeking to attract the attention of the Emperor and his supervising courts to stop further bloodshed in Franconia (Voltmer 2020).

An important eyewitness for this empire-wide discourse is Heinrich of Schultheiß, the notorious witch commissioner of Westphalia and Cologne, whose testimony has been largely forgotten, although he had published it in his apologetic tract (1634). ${ }^{56}$ Along with Licentiate Kaspar Reinhard, Dr Johannes Moeden and Dr Franz Buirmann, Schultheiß belonged to the group of Witch Commissioners (Hexenkommissare) who played a pivotal role in the sentencing to death of hundreds of people during the witch-trials that occurred in Electoral Cologne, particularly during the severe persecutions in 1626-1631. Educated by Jesuits and gaining low ordination to obtain a canonry, he then studied law

55 See footnote 4

56 Alison Rowlands at first (2019) has referred to Schultheiß and his comments about the executed witch-clerics in Würzburg. 
at the University of Cologne and Würzburg (1603). He subsequently left the clergy and step by step started his career as a witch commissioner, already active in 1616/1617 and 1621. Around 1630 he participated in the severe persecution of witches in the Duchy of Westphalia which claimed between 650 and 1000 victims. Around 1632/1634 Schultheiß was ennobled: A clear indication of his rapid social rise. He had to flee to Cologne in 1633 as a result of the effects of the Thirty Years War. Obviously, Schultheiß wrote the tract to defend his work against the growing discourse which labelled massive witch-hunting nothing but shedding of innocent blood (Eine Außführliche Instruction Wie in Inquisition Sachen des grewlichen Lasters der Zauberey [ . . ] ohn gefahr der Unschuldigen zu procediren $\left.[\ldots])^{57}\right)$. He justified his own role in the trials, called for further persecution, and offered a guide on how the guilt of alleged witches could best be proven in court. The tract aimed at nobles and minor lords, since, in consequence of warfare and of imperial intercession in the electorates of Cologne and Mainz as well as in the bishoprics of Franconia and Swabia, the witch-hunts had ceased. Inter alia ${ }^{58}$, Schultheiß blamed the devil, the witches' sect and their favourites, the patroni sagarum, of having spread insulting rumours about the witch trials in Würzburg. These rumours, according to Schultheiß, culminated in the argument that the wrath of God had punished the prince bishops of Mainz, Cologne, and Würzburg for their tyrannical blood justice with the loss of their territories during the war.

According to Schultheiß, the erroneous claim made by the patroni sagarum, that Jesuits had been executed as witches in Würzburg, had scared members of the Society. Schultheiß, still having good connections with the privy council in Würzburg, relied on its freshly won testimony that in the prince bishopric neither monks nor Jesuits had been arrested or executed. The witch-trials against the canons had been allegedly conducted with the greatest caution and with respect to every clause of ecclesiastical and secular law. Schultheiß tried hard to defend in general the Franconian witch-hunts, and particularly the trials against clerics. This defence fits with his general attack against the sceptical voices of Adam Tanner, SJ, (whom he named personally), probably Paul Laymann, SJ, and Dr Cornelius Pleier, a freshly conversed Catholic (referring to his treatise). Those Jesuits, who had joined the public discourse against the shedding of innocent blood during the witch-hunts in Franconia (and implicitly in Westphalia), had to stand the most vicious counter-argument of Schultheiß: They had been deluded by false rumours made by patroni sagarum and the synagogue of demons and witches. For Schultheiß, however, the clergy need not be blamed because of the witch-priests, since even the Apostles had one Judas amongst them.

The testimony of Heinrich of Schultheiß proves the existence of a widespread discourse about the legitimacy of massive witch-hunts which did not spare high ranking men and their families, together with parish priests and canons. However, it is remarkable that the witch commissioner, who tried so hard to devalue every argument in this discourse, mentioned the Cautio Criminalis only on the margins, without naming its title (Decker 1996, pp. 1052-53). Perhaps Schultheiß had not read the book, according to his remarks. It seems, however, more likely that Schultheiß intentionally avoided a difficult discussion of Spee's well set arguments which defamed sharply the witch-trials conducted by ecclesiastical princes against their fellow clerics.

\section{Friedrich Spee and the Priest-Witch—Final Arguments}

The life and work of the well-known Jesuit Friedrich Spee has been recently studied thoroughly, laying emphasis on his embeddedness in the order's networks. Spee either had heard first-hand information about the procedure of the witch-trials or he had eye witnessed them during his stays in Trier, Mainz, Cologne, Paderborn, Fulda, or Würzburg (Sobiech 2019; Hellyer 2003). In 1631, he published anonymously the first edition of his Cautio Criminalis, addressed to princes and authorities,

57 "Detailed Instruction, on how to proceed against the dreadful crime of witchcraft ... without any danger to those innocent of the crime".

58 For Schultheiß and his comments about the major witch-hunts in Westphalia, Würzburg, and Bamberg see in detail (Voltmer 2020). 
followed in 1632 by the second edition. Relying on Adam Tanner and criticising sharply Peter Binsfeld and Martin Delrio, Spee focused on the criminal procedure and the impact of torture. He advocated stopping the injustice of witchcraft trials, but avoided discussing the belief in witchcraft. To Spee, several groups of perpetrators kept the bloody machine of witchcraft trials running, including clerics and father confessors, jurists and witch commissioners, and the populace. In general, authorities, who allowed massive trials, acted like tyrants shedding the blood of the innocent.

It has slipped attention that rather frequently Spee referred to cases of tortured and executed witch-priests, although without revealing names or dates. He complained bitterly about ecclesiastical princes, who allowed their inquisitors to lay hands on ordained priests and clerics in disrespect of papal bulls and ecclesiastical privileges, but based on weak evidence. If justice failed in criminal procedure against clerics, "what do other, common souls have to hope for" (Spee 2003, p. 61). Implicitly referring to the witch-trials in Ellwangen, Eichstätt, Bamberg, and Würzburg, Spee expressed his horror at criminal trials in which even priests had to endure the humiliating procedure of being shaved by the hands of the infamous torturer (Spee 2003, pp. 127, 217). He could not understand ecclesiastical princes who gave the secular witch commissioners free reign to ask leading questions about whether the accused women had seen "any parish priests or churchmen at their sabbaths" (Spee 2003, p. 81). Spee knew about a princely prelate who had recently "forbade one of his inquisitors to ask about churchmen either in general or in particular", because the prince had been advised that these women under torture might name not only ordinary priests but likewise high-ranking prelates (Spee 2003, p. 81). Maybe this example referred to Bamberg, where trials against clerics had stopped after the suffragan bishop Förner had been denounced himself. Another example stemmed from a "well-known place in Germany where almost everything burned to ashes" (Spee 2003, p. 196). Spee told the story about a table talk between an ecclesiastical prince and one of his clerical advisers about whether the witchcraft trials were conducted properly and whether innocent people had been accused falsely. The zealous regular priest defended the bloody justice with the argument that God never would allow the shedding of innocent blood. At the end of the dispute, the prince confronted the Father with the fact that no less than fifteen convicted witches had confessed that they had seen him at their sabbaths. Thus, the Father had condemned himself as a witch. This story has been identified as a dialogue exchanged between the prince bishop of Eichstätt and the Cathedral preacher, the Jesuit Joachim Megglin (Schwillus 1992, p. 121).

Spee demanded that priests, whose arrest had been based on weak evidence, should be granted writing implements for their defence (Spee 2003, p. 67). Spee was well informed that in one case an ecclesiastical prince had forbidden an incarcerated cleric from sending out a supplication, although the regular order of the arrested cleric had plead for the latter. This story seems to refer to the four monks of Dalheim who had been arrested as witches in 1600. On another occasion, Spee complained more about this monastery case (Spee 2003, pp. 62, 187; Decker 2000, p. 235). The cruel inquisitors of ecclesiastical princes had even sent a Catholic priest to the stake who had endured torture several times without any confession of witchcraft (Spee 2003, pp. 211, 217). Spee and others expressed a lack of understanding about why prelates and ecclesiastical princes had not complained about the mistreatment of the clergy and the disregard for ecclesiastical privileges during the witch-trials (Spee 2003, p. 61). With similar arguments to the Catholic pamphlet of 1603, Spee listed the damage done by witch-trials, disgracing the Catholic faith, because pious Catholics avoided showing devotion openly in saying the rosary or praying in church, since this behaviour would bring them immediately under suspicion of witchcraft. In an unnamed nearby territory, everybody protected himself "as diligently as possible against displaying any sign of piety". (Spee 2003, p. 24). Spee goes on: "Even priests who used to celebrate mass daily have now either ceased completely or say it only in private with the church locked up, lest people begin to spread rumors of magic" (ibid.). In doing so, Spee bitter affirmed, witch-hunts in ecclesiastical territories paved the way for atheism.

It seems clear to me that Spee, through the Jesuit's network, knew very well about the empire-wide discourse which reached from Bavaria and Franconia to Westphalia, and was carried inter alia by Jesuits, 
concerning the legitimacy of massive witch-hunts, especially in ecclesiastical territories. His arguments were based on Adam Tanner who may have known the pamphlet of 1603 and its author, a presumed Jesuit. Furthermore, I assume that these arguments were circulating around 1600 at least between those members of the Jesuit order who were developing a growing scepticism against the procedure in witch-trials. Spee used the figure of the witch-cleric thus to exemplify the massive irregularities going on during the trials, the injustice and cruelty of torture, the blindness and ruthlessness of ecclesiastical princes who handed ordained priests to secular inquisitors. Spee's last hope happened to be the Emperor who certainly would be disgusted "if he hears that in his empire even ecclesiastical persons have perished" through false sentences in the witch-trials (Spee 2003, p. 97). Finally, and again in using the figure of the witch-cleric, Spee brought forward a strong confessional argument: "It will be much more shameful if it is heard that this same satanic testimony has such strength among Germans that it is even accepted as evidence against ecclesiastical persons. This will cause the greatest contempt for the Catholic faith among heretics [Protestants]. Nevertheless such testimony has been accepted in this way under Church princes" (Spee 2003, p. 210). Implicitly and explicitly and together with his complaints against zealous clerics and relentless father confessors, who belonged to his order, Spee thus uttered a massive criticism of the Church in the Old Reich, which was not able or not willing to shield ordained priests from prosecution. ${ }^{59}$ This counter-argument targeted vigorously the argument of Catholic overzealous promoters of witch-hunting such as Binsfeld, Delrio, and especially Förner who with a twisted logic had strengthened the idea that every conquered and convicted witch proved the ultimate truth of post-Tridentine Catholic faith. To Spee, the ruthless witch commissioners and inquisitors (and one may say, their masters, the ecclesiastical princes themselves), indeed, were the worst witches. In here, Spee's critic echoes arguments of the Protestant Nigrinus.

\section{Conclusions and Prospects}

1. In Western Europe, only few territories saw clusters of trials against witch-clerics, although many friars, monks, and secular priests had a notorious reputation as necromancer, sorcerer, and magician. Several factors prevented or triggered deadly trials against clergymen, such as legal centralization and scepticism (e.g., under the auspices of the Spanish Inquisition), counter-reformation and Catholic reform (e.g., in the ecclesiastical territories of the Old Reich), or the enthusiasm of witch-hunters (e.g., Sebastian Michaëlis, Pierre de Lancre, or the witch commissioners of Westphalia and Cologne).

2. Patterns of accusations shifted during different patterns of trials. The convent cases in France or Italy with one or two charged witch-clerics followed a different pattern in comparison with the witch-hunts in Franconia and its massive assault against canonry. Protestant polemics again smoothed away the differences, propagating that many tried priests and monks had engaged in devil's baptism, a charge, which cannot be proved with the surviving trial records.

3. Popular and learned anticlericalism fueled the discourse about the devil's clergy, and bolstered accusations against Catholic clergymen (and their housekeepers or concubines).

4. The figure of the witch-priest played a vital role in campaigns for Catholic reform and in clerical infighting. Dominican inquisitors in Italy or France proved their outstanding expertise in battling necromancers and witch-priests in competition with Jesuits or other branches of the Mendicant orders, whereas Jesuits with their new post-Tridentine concepts of clerical standards uncovered worldly living urban canons and rural parish priests as the devil's minions.

5. The persecution of the Anabaptist and the demonization of re-baptism strengthened anxieties about the devil's baptism, performed by witch-clerics, and mixed with fantasies about consecrating children to the devil, done by the mothers (and sometimes fathers), and the devil's re-baptism at the witches' sabbath. 
6. Demonology and the media debated the devil's clergy during late medieval and early modern times in constant dialogue with actual trials. The persecution of Catholic clergy played at least two significant roles in political demonology and in the media. For Catholics, the figure of the witch-cleric proved that Satan was vigorously assaulting post-Tridentine Catholicism, the only remaining bulwark of Christianity; for Protestants on the other hand, the news about the devil's clergy proved that Satan reigned in popedom. Secondly and from the start of the 17th century, the prosecution of clerics as the devil's minions fueled the general debates about the legitimacy of witchcraft trials in the Old Reich. For advocates of witch-hunting, executed witch-clerics proved the omnipresent dangers of witchcraft and the satanic infiltration of Christian society, whereas for sceptics like Friedrich Spee, the same narratives proved the witch-trials to be the work of tyrants, shedding the innocent blood of martyrs.

7. The new standards of post-Tridentine Catholic faith, transmitted by the Jesuit role model, brought forward tools of how to unmask the witch-cleric. In the figure of the witch-cleric, counter-reformation, Catholic reform, and witch-hunting amalgamated. In the Old Reich, Jesuits together with ecclesiastical princes and their administration were eager to detect superstitious, lecherous priests, and canons in the name of Catholic reform. It happened to be Jesuits, whose exorcisms, devoted processions, theatre, and mission campaigns, transmitted the idea of diabolic omnipresence to rural parishes as well as to the urban milieu. However, there existed no order-wide strategy to extirpate the priest-witches. Every Jesuit Father had to decide for himself, how much and in which way he engaged in favour of witch-trials.

8. Already in the 16th century, demonologists and propagandists attached the label patronus sagarum to Jesuits and Catholic clerics to discredit them as witches themselves. Some of them indeed had been protectors of accused people. Witch-hunters, likewise, used the label as a strategic argument of legitimation. After the turn of the century and with increasing experience as father confessors, more and more Jesuits (although still the minority) developed sceptical views, demanding a care for innocents and to hinder further bloodshed. However, the Jesuit order never propagated a consistent opinion towards the belief in witches, and the procedure in trials. It remained difficult for many fathers as members of the strike force of counter-reformation to accept the view of Spee and others.

9. No Jesuit was executed as a witch, as far as we know, but some of them frequently were denounced as witches, and their students had to stand deadly trials. Witchcraft accusations against Jesuits or their presumed executions did not stop further witch trials. Heinrich of Schultheiß circulated this polemical argument to ridicule and defame the Jesuits' sceptical voices as being the mere result of satanic delusion. Nor did trials against witch-clerics stop the zeal of (ecclesiastical) witch-hunters. Würzburg with its nearly 50 executions seems to be an outstanding exception, as long as we do not take into account that in Eichstätt, Bamberg, and Cologne more trials against the devil's clergy were in preparation, but stopped because of the steadfastness of one parish priest (Eichstätt), or because of the fact that accusations began to reach very high-ranking clerics. With the suffragan bishops of Cologne (Otto Gereon) and Bamberg (Friedrich Förner) denounced as witches, indeed, a "crisis of confidence" occurred.

10. In following Spee's argument, ecclesiastical princes in the Old Reich had failed entirely to shield the clergy. On the contrary, they had ordered secular inquisitors to inquire explicitly for seemingly suspicious clerics. If the Imperial courts had not blocked the Franconian and Cologne witch-hunts, there is little doubt that more clerics would have fallen prey to them.

11. The history of the devil's clergy mirrors the great diversity of clerical rank, economic resources, and location (rural/urban). For example, anxieties about the devil's baptism mainly targeted parish priests in rural and urban milieu. Vicars, chantry priests, monks, and canons without any duties in pastoral care, had to have less fear of these accusations, whilst canons and monks fell into suspicion more frequently because of their supposed idleness, and lechery. Rural priests 
were accused of diabolic superstition and magic. Protestant polemics, however, smoothed away these vital differences and created indeed the stereotype of the Catholic witch-cleric.

12. Demonology and the media had marked the witch-cleric as a super-witch, driving a flock, or a convent into the devil's snare. Social history, however, should put the witch-cleric back into his respective milieu to gain better insight into the dynamics of how and why certain Protestant ministers and Catholic priests, together with their family and kin, were suspected of witchcraft. Many of their partners (be they concubines or wives), kin, and family, be they Catholic or Protestant, had fallen prey to witch-trials. Like other housefathers, clerics headed so-called witches' families or witches' households (Voltmer 2016, pp. 218-26; Rowlands 2016; de Blécourt 2007)..$^{60}$ Witchcraft slander suits would be useful for gaining insight into the emergence of accusations against clerics. Likewise, we should not forget about the accused, incarcerated, and executed nuns and women religious. The history of the witch-cleric should focus not only on the executed or punished men but should try to identify those who were denounced but not tried or executed or who were able to take to the road. Any discussion thus about the alleged small number of executed clerics is misleading.

13. We should identify the clerical networks, whose members were either promoters of witch-hunting, or victims, or both or who developed scepticism. Cornelius Loos and Friedrich Spee, defamed as patroni sagarum, were only the tip of the iceberg.

Funding: This research received no external funding.

Conflicts of Interest: The author declares no conflict of interest.

\section{References}

Apps, Lara, and Andrew Gow. 2003. Male Witches in Early Modern Europe. Manchester and New York: Manchester University Press.

Arnold, John H. 2014. The Oxford Handbook of Medieval Christianity. Oxford: Oxford University Press.

Bailey, Michael. 2001. From Sorcery to Witchcraft: Clerical Conceptions of Magic in the Later Middle Ages. Speculum 76: 960-90. [CrossRef]

Bailey, Michael. 2003. Battling Demons. Witchcraft, Heresy, and Reform in the Late Middle Ages. Pennsylvania: The Pennsylvania State University Press.

Bailey, Michael. 2019. Superstition and Sorcery. In The Routledge History of Medieval Magic. Edited by Sophie Page and Catherine Rider. London: Routledge, pp. 487-501.

Bamji, Alexandra, Geert H. Janssen, and Mary Laven. 2013. The Ashgate Research Companion to the Counter-Reformation. Burlington and Farnham: Ashgate.

Baron, Frank. 2019. Der Mythos des faustischen Teufelspakts. Geschichte, Legende, Literatur. Berlin and Boston: Walter de Gruyter GmbH.

Bauer, Manuel. 2018. Der literarische Faust-Mythos. Grundlagen-Geschichte—Gegenwart. Stuttgart: J.B. Metzler Verlag.

Behringer, Wolfgang. 1997. Falken und Tauben. Zur Psychologie deutscher Politiker im 17. Jahrhundert. In Problems in the Historical Anthropology of Early Modern Europe. Edited by Ronnie Po-Chia Hsia and Robert W. Scribner. Wiesbaden: Harrasowitz, pp. 219-61.

Behringer, Wolfgang. 2009. Witchcraft in the Media. In Ideas and Cultural Margins in Early Modern Germany. Essays in Honor of H. C. Erik Midelfort. Edited by Marjorie Elizabeth Plummer and Robin Barnes. Farnham: Ashgate Publishing, Ltd., pp. 217-36.

60 To give one example: In the village of Fell (St Maximin), the parish priest suffered execution as a presumed witch in 1589. Four members of his former household shared his fate (1591-1595), including his two daughters, his son-in-law, and his female servant (Voltmer and Weisenstein 1996, p. 404). 
Blackwell, Jeannine. 2000. German Narratives of Women's Divine and Demonic Possession and Supernatural Vision 1550-1800. A bibliography. Women in German Yearbook: Feminist Studies in German Literature and Culture 16: 241-57. [CrossRef]

Bodin, Jean. 2011. On the Demon-Mania of Witches. Translated by Randy A. Scott. With an Introduction by Jonathan L. Pearl. Toronto: Centre for Reformation and Renaissance Studies. First published 1580.

Boudet, Jean-Patrice. 2019. Magic at Court. In The Routledge History of Medieval Magic. Edited by Sophie Page and Catherine Rider. London: Routledge, pp. 331-42.

Boureau, Alain. 2004. Le Pape et les Sorciers. Une sonculatation de Jean XII sur la Magie en 1320 (Manuscrit B.A.V. Borghese, 348). Rome: Bibliothèque de l'École francaise de Rome.

Boureau, Alain. 2006. Satan the Heretic. The Birth of demonology in the Medieval West. Chicago and London: The University of Chicago Press.

Boutcher, Warren. 2017. The School of Montaigne in Early Modern Europe. Vol. 1: The Patron-Author. Oxford: Oxford University Press.

Brakke, David. 2006. Demons and the Making of the Monk: Spiritual Combat in Early Christianity. Cambridge: Harvard University Press.

Briggs, Robin. 2007. The Witches of Lorraine. Oxford: Oxford University Press.

Brunold-Bigler, Ursula. 2003. Teufelsmacht und Hexenwerk. Lehrmeinungen und Exempel in der "Magiologia" des Bartholomäus Anhorn (1616-1700). Chur: Kommissionsverlag Desertina.

Burkardt, Albrecht. 1997. A False Living Saint in Cologne in the 1620s: The Case of Sophia Agnes von Langenberg. In Illness and Healing Alternatives in Western Europe. Edited by Marijke Gijswijt-Hofstra, Hilary Marland and Hans de Waardt. London and New York: Routledge, pp. 80-97.

Cameron, Euen. 2010. Enchanted Europe. Superstition, Reason, and Religion, 1250-1750. Oxford: Oxford University Press.

Clark, Stuart. 1997. Thinking with Demons: The Idea of Witchcraft in Early Modern Europe. Oxford: Oxford University Press.

Costa, Gustavo. 1990. Love and Witchcraft in Gianfrancesco Pico della Mirandola: La Strega between the Sublime and the Grotesque. Italica 67: 427-39. [CrossRef]

Dall'Olio, Guido. 2006. Convent Cases. In The Encyclopedia of Witchcraft. The Western Tradition. Edited by Richard M. Golden. St. Barbara: ABC Clio, pp. 215-16.

Dall'Olio, Guido. 2012. The Devil of Inquisitors, Demoniacs and Exorcists in Counter-Reformation Italy. In The Devil in Society in Premodern Europe. Edited by Peter J. Dendle and Richard Raiswell. Toronto: Centre for Reformation and Renaissance Studies, pp. 511-36.

de Blécourt, Willem. 1994. Witch Doctors, Soothsayer and Priests. On Cunning Folk in European Historiography and Tradition. Social History 19: 285-303. [CrossRef]

de Blécourt, Willem. 2007. Hexenfamilien—Zauber(er)geschlechter. Das Beispiel Drenthe (17-19. Jahrhundert). In Familienbande-Familienschande. Geschlechterverhältnisse in Familie und Verwandtschaft. Köln, Weimar and Vienna: Böhlau Verlag, pp. 121-45.

de Lancre, Pierre. 2006. On the Inconstancy of Witches. Pierre de Lancre's Tableau de l' inconstance des mauvais anges et demons (1612). Edited by Gerhild Scholz Williams. Tempe: Brepols. First published 1612.

Decker, Rainer. 1978. Die Hexenverfolgungen im Hochstift Paderborn. Westfälische Zeitschrift 128: 314-56.

Decker, Rainer. 1996. Der Hexen-Richter Dr. Heinrich von Schultheiß (ca. 1580-1646) aus Scharmede. In 750 Jahre Stadt Salzkotten. Geschichte einer westfälischen Stadt. Edited by Detlef Grothmann. Paderborn: Bonifatius, vol. 2, pp. 1045-60.

Decker, Rainer. 2000. Hexen, Mönche und ein Bischof. Das Kloster Dalheim und das Problem des Hexensabbats um 1600. Westfälische Zeitschrift 150: 235-45.

Decker, Rainer. 2003. Der Brillen-Traktat des Michael Stappert als Bestandteil von Hermann Löhers wehmütiger Klage. Annalen des Historischen Vereins für den Niederrhein 206: 159-68. [CrossRef]

Decker, Rainer. 2008. Witchcraft and the Papacy. An Account Drawing on the Formerly Secret Records of the Roman Inquisition. Charlottesville: University of Virginia Press.

Del Olmo, Ismael. 2018. ,A Savage Conversion'. Unbelief and Demonic Possession in Pierre de Bérulle's Traitè des ènergumènes (1599). Revue d'histoire ecclésiastique 113: 189-210. [CrossRef]

Delumeau, Jean. 1977. Catholicism between Luther and Voltaire: A New View of the Counter-Reformation. With an Introduction by John Bossy. London: Burns \& Oats. 
Dillinger, Johannes. 2012. Treasure Hunting. A History. Basingstoke: Palgrave Macmillan.

Dinzelbacher, Peter. 2006. Clergy. In The Encyclopedia of Witchcraft. The Western Tradition. Edited by Richard M. Golden. St. Barbara: ABC Clio, pp. 193-97.

Duni, Matteo. 2007. Under the Devil's Spell. Witches, Sorcerers, and the Inquisition in Renaissance Italy. Syracuse and New York: Syracuse University Press.

Durrant, Jonathan B. 2007. Witchcraft, Gender and Society in Early Modern Germany. Leiden and Boston: Brill.

Dykema, Peter A., and Heiko A. Oberman. 1993. Anticlericalism in Late Medieval and Early Modern Europe. Leiden, New York and Köln: Brill.

Ferber, Sarah. 2004. Demonic Possession and Exorcism in Early Modern France. London and New York: Routledge.

Ficzel, Nelly. 2019. Der Papst als Antichrist. Kirchenkritik und Apokalyptik im 13. Und frühen 14. Jahrhundert. Leiden: Brill.

Förner, Friedrich. 2011. Magie-Krankheit der Seele. Panoplia Armaturae Dei, adversus omnem superstitionum, divinationum, excantationum, daemonolatriam, et universas magorum, veneficorum, et sagarum [ ... ]. Translated and Edited by Burghard Schmanck. Nordhausen: Verlag Traugott Bautz. First published 1625.

Franz, Gunther. 1980. Eine Schmähschrift gegen die Jesuiten. Kaiserliche Bücherprozesse und konfessionelle Polemik (1614-1630). In Bücher und Bibliotheken im 17. Jahrhundert in Deutschland. Edited by Paul Raabe. Hamburg: Hauswell, pp. 91-114.

Fuchs, Ralf-Peter. 2019. Hexen aus freiem Willen. Peter Binsfeld und das tridentinische Liberum-Arbitrium-Dogma. Rheinische Vierteljahrsblätter 83: 1-20.

Gehm, Britta. 2000. Die Hexenverfolgung im Hochstift Bamberg und das Eingreifen des Reichshofrates zu ihrer Beendigung. Hildesheim, Zürich and New York: Georg Olms Verlag.

Geltner, Guy. 2012. The Making of Medieval Antifraternalism: Polemic, Violence, Deviance, and Remembrance. Oxford: Oxford University Press.

Gibson, Marion. 1999. Reading Witchcraft. Stories of Early English Witches. London and New York: Routledge.

Gibson, Marion. 2006. Possession, Puritanism and Print: Darrell, Harsnett, Shakespeare and the Elizabethan Exorcism Controversy. London: Pickering \& Chatto.

Goodare, Julian, Rita Voltmer, and Liv Helene Willumsen, eds. 2020. Demonology and Witch-Hunting in Early Modern Europe. London: Routledge, in print.

Harms, Wolfgang. 1985. Deutsche illustrierte Flugblätter des 16. und 17. Jahrhunderts. Tübingen: Niemeyer, vol. 1.

Harvey, Margaret. 1973. Papal Witchcraft: The Charges Against Benedict XIII. In Sanctity and Secularity: The Church and the World. Edited by Derek Baker. Oxford: Ecclesiastical History Society, pp. 109-16.

Hellyer, Marcus. 2003. Translator's Introduction. In Spee, Friedrich. Cautio Criminalis, or a Book on Witch Trials. Translated by Marcus Hellyer. Charlottesville and London: Virginia University Press, pp. vii-xxxvi.

Herzig, Tamara. 2003. The Demons' reaction to Sodomy: Witchcraft and Homosexuality in Gianfrancesco Pico della Mirandola's "Strix". The Sixteenth Century Journal 34: 53-72. [CrossRef]

Herzig, Tamat. 2011. The Demons and the Friars. Illicit Magic and Mendicant Rivalry in Renaissance Bologna. Renaisance Quarterly 64: 1025-58. [CrossRef]

Hill, Kat. 2015. Baptism, Brotherhood, and Belief in Reformation Germany. Oxford: Oxford University Press.

Hillgarth, Jocelyn N. 1996. The Image of Alexander VI and Cesare Borgia in the Sixteenth and Seventeenth Centuries. Journal of the Warburg and Courtauld Institutes 50: 119-29. [CrossRef]

Janssen, Johannes. 1910. History of the German People after the Close of the Middle Ages. London: Kegn Paul, Trench Trubner \& Co. Ltd., vol. 16.

Kallestrup, Louise Nyholm. 2018. "Kind in Words and Deeds, but False in Their Hearts": Fear of Evil Conspiracy in Late-Sixteenth-Century Denmark. In Cultures of Witchcraft in Europe from Middle Ages to the Present. Edited by Jonathan Barry, Owen Davies and Cornelie Usborne. Basingstoke: Palgrave Macmillan, pp. 137-53.

Kieckhefer, Richard. 1990. Magic in the Middle Ages. Cambridge: University Press.

Klaassen, Frank. 2019. Necromancy. In The Routledge History of Medieval Magic. Edited by Sophie Page and Catherine Rider. London: Routledge, pp. 201-11.

Knutsen, Gunnar W. 2009. Servants of Satan and Masters of Demons. The Spanish Inquisition's Trials for Superstition, Valencia and Barcelona, 1478-1700. Turnhout: Brepols.

Kuznicki, Jason T. 2007. Sorcery and Publicity: The Cadière-Girard Scandal of 1730-1731. French History 21: 289-312. [CrossRef] [PubMed] 
Lambrecht, Karen. 1995. Hexenverfolgung und Zaubereiprozesse in den schlesischen Territorien. Köln, Weimar and Wien: Böhlau Verlag.

Lea, Henry Charles. 1939. Materials Toward a History of Witchcraft. Edited by Arthur C. Howland. New York and London: Thomas Yoseloff.

Lebec, Éric, ed. 1997. Miracles et sabbats. Journal du Père Maunoir missions den Bretagne, 1631-1650. Anne-Sophie, and Jérôme Cras, transs. Paris: Éditions de Paris.

Levack, Brian P. 2013. The Devil Within. Possession and Exorcism in the Christian West. New Haven and London: Yale University Press.

Machielsen, Jan. 2015. Martin Delrio: Demonology and Scholarship in the Counter-Reformation. Oxford: Oxford University Press.

Machielsen, Jan. 2019. 'The Making of a Teen Wolf: Pierre de Lancre's Confrontation with Jean Grenier (1603-19). Folklore 130: 237-57. [CrossRef]

Maggi, Armando. 2006. To Read the Body of a Monster. Exegesis and Witchcraft in Strix by Giovan Francesco Pico della Mirandola. In In the Company of Demons. Unnatural Beings, Love, and Identity in the Italian Renaissance. Chicago and London: The University of Chicago Press, pp. 25-65.

Mährle, Wolfgang. 1998. 'O wehe der armen Seelen'. Hexenverfolgungen in der Fürstpropstei Ellwangen (1588-1694). In Dillinger, Johannes, Thomas Fritz, and Wolfgang Mährle, Zum Feuer verdammt. Die Hexenverfolgungen in der Grafschaft Hohenberg, in der Reichsstadt Reutlingen und der Fürstpropstei Ellwangen. Stuttgart: Franz Steiner Verlag.

Maus de Rolley, Thibaut. 2016. The English Afterlife of a French Magician: The Life and Death of Lewis Gaufredy (1612). In Seventeenth-Century Fiction: Text and Transmission. Edited by Jacqueleine Glomski and Isabelle Moreau. Oxford: Oxford University Press, pp. 34-48.

Maxwell-Stuart, Peter G. 2000. Martín del Rio: Investigations into Magic. Manchester: Manchester University Press.

Meder, David. 1605. Acht Hexenpredigten Von des Teuffels Mordkindern, der Hexen, Unholden [ ... ] Abfalle, Lastern und Ubelthaten [ ... ]. Leipzig: Apel.

Midelfort, H. C. Erik. 1972. Witch-Hunting in Southwestern Germany 1562-1684. The Social and Intellectual Foundations. Standford: University Press.

Mollenhauer, Lynn Wood. 2006. Clerical Magic. In The Encyclopedia of Witchcraft. The Western Tradition. Edited by Richard M. Golden. St. Barbara: ABC Clio, pp. 197-98.

Monter, William. 1976. Witchcraft in France and Switzerland. The Borderlands During the Reformation. Ithaca and London: The Cornell University Press.

Monter, William. 1990. Frontiers of Heresy. The Spanish Inquisition from the Basque Lands to Sicily. Cambridge: Cambridge University Press.

Monter, William. 1997. Toads and Eucharists: The Male Witches of Normandy, 1564-1660. French Historical Studies 20: 563-95. [CrossRef]

Monter, William. 2002. Witch Trials in Continental Europe, 1560-1660. In The Athlone History of Witchcraft and Magic in Europe: The Period of Witch Trials. Edited by Bengt Ankarloo, Stuart Clark and William Monter. London: Bloomsbury, pp. 1-52.

Monter, William. 2007. A Bewitched Duchy: Lorraine and its Dukes, 1477-1736. Geneva: Librairie Droz S.A.

Montesano, Marina. 2018. Classical Culture and Witchcraft in Medieval and Renaissance Italy. Basingstoke: Palgrave Macmillan.

Mullett, Michael. 2010. Historical Dictionary of the Reformation and Counter-Reformation. Lanham, Toronto and Plymoth: The Scarecrow Press.

Muschiol, Gisela. 2004. Zeugen, Opfer, Gegner oder Täter? Die Rollen geistlicher Frauen und Männer in Hexenprozess-ein Forschungsüberblick. In Hexenwahn. Eine theologische Selbstbestimmung. Edited by Renate Jost and Marcel Nieden. Stuttgart: Verlag W. Kohlhammer, pp. 71-88.

Ostorero, Martine. 2003. Un prédicatuer au cachot: Guillaume Adeline et le sabbat. Médiévales. Langues, Textes, Histoire 44: 1-20.

Ostorero, Martin. 2019. Witchcraft. In The Routledge History of Medieval Magic. Edited by Sophie Page and Catherine Rider. London: Routledge, pp. 502-22.

Paintner, Ursula. 2011. Des Papsts neue Creatur. Antijesuitische Publizistik im deutschsprachigen Raum (1555-1618). Amsterdam and New York: Editions Rodopi B.V. 
Parish, Helen. 2015. Magic and Priestcraft: Reformers and Reformation. In The Cambridge History of Magic and Witchcraft in the West. From Antiquity to the Present. Edited by David J. Collins SJ. Cambridge: Cambridge Univesity Press, pp. 393-425.

Pearl, Jonathan L. 1999. The Crime of Crimes. Demonology and Politics in France, 1560-1620. Waterloo: Wilfried Laurier University Press.

Po-Chia Hsia, Ronnie. 2005. The World of Catholic Renewal 1540-1770. Cambridge: Cambridge University Press.

Pohl, Herbert. 1998. Zauberglaube und Hexenangst im Kurfürstentum Mainz. Ein Beitrag zur Hexenfrage im 16. und beginnenden 17. Jahrhundert. Stuttgart: Franz Steiner Verlag Wiesbaden.

Rafferty, Oliver P., SJ. 2017. Martyrs, Ideal and History. In The Cambridge Encyclopedia of the Jesuits. Edited by Thomas Worcester SJ. Cambridge: Cambridge University Press, pp. 506-7.

Rietbergen, Peter. 2006. Power and Religion in Baroque Rome. Barberini Cultural Policies. Leiden and Boston: Brill.

Robbins, Kevin C. 1997. Magical Emasculation, Popular Anticlericalism, and the Limits of the Reformation in Western France circa 1590. Journal of Social History 31: 61-83. [CrossRef]

Robisheaux, Thomas. 2018. Review of 'Heinz Sieburg, Rita Voltmer, Britta Weimann (Hg.), Hexenwissen. Zum Transfer von Magie- und Zauberei-Imaginationen in interdisziplinärer Perspektive, Trier 2017 [ ... ]. Francia Recensio 4. [CrossRef]

Roelants, Nienke, and Dries Vanysacker. 2005. Tightrope Walkers on the Border between Religion and Magic. A Study of the Attitudes of Catholic Clerics North of the Linguistic Frontier within the Souther Netherlands towards Superstition and the Crime of Witchcraft (1550-1650). Revue d'Histoire Ecclesiastique 2005: 754-96. [CrossRef]

Rowlands, Alison. 2016. Gender, Ungodly Parents, and a Witch Family in Sevententh-Century Germany. Past and Present 232: 45-86. [CrossRef]

Rowlands, Alison. 2019. The Witch-Cleric Stereotype in a Seventeenth-Century Lutheran Context. German History 37: 1-23. [CrossRef]

Schormann, Gerhard. 1991. Der Krieg gegen die Hexen. Das Ausrottungsprogramm des Kurfürsten von Köln. Göttingen: Vandenhoeck \& Ruprecht.

Schulte, Rolf. 2009. Man as Witch. Male Witches in Central Europe. Basingstoke: Palgrave Macmillan.

Schwillus, Harald. 1989. Die Hexenprozesse gegen Würzburger Geistliche unter Fürstbischof Philipp Adolf von Ehrenberg (1623-1631). Würzburg: Echter Verlag.

Schwillus, Harald. 1992. Kleriker im Hexenprozeß. Geistliche als Opfer der Hexenprozesse des 16. und 17. Jahrhunderts in Deutschland. Würzburg: Echter Verlag.

Seebaß, Gottfried. 1966. Das Problem der Konditionaltaufe in der Zeit der Reformation. Zeitschrift für bayerische Kirchengeschichte 35: 138-68.

Sievernich, Michael, SJ. 2005. Mystik zwischen Poesie und Politik-Zur Kirchenkritik im Werk des Friedrich Spee SJ. In Die Kirchenkritik der Mystiker. Prophetie aus Gotteserfahrung. Vol 2: Frühe Neuzeit. Edited by Mariano Delgado and Gotthard Fuchs. Stuttgart: W. Kohlhammer Verlag GmbH.

Smith, William Bradford. 2005. Friedrich Förner, the Catholic Reformation and Witch-Hunting in Bamberg. Sixteenth Century Journal 36: 115-28.

Smith, William Bradford. 2008. Reformation and the German Territorial State. Upper Franconia, 1300-1630. Rochester: University Press.

Sobiech, Frank. 2019. Torture and Confession. Jesuit Prison Ministry During the Witch Trials in the Holy Roman Empire and the Cautio Criminalis by Friedrich Spee SJ (1591-1635). Rome: Institutum Historicum Societas Iesu, in print.

Spee, Friedrich. 2003. Cautio Criminalis, or a Book on Witch Trials. Translated by Marcus Hellyer. Charlottesville and London: Virginia University Press. First Published in 1632.

Spence, Caroline Q. 2009. The Trial of Louis Gaufridy: Possession, Heresy, and the Devil's Mark, 1609-1611. In Essay in History. The Annual Journal produced by the Corcoran Departement of History at the University of Virginia 42. Available online: http://www.essaysinhistory.com/the-trial-of-louis-gaufridy-possession-heresy-andthe-devils-mark-1609-1611/ (accessed on 17 November 2019).

Stephens, Walter. 2002. Demon Lovers. Witchcraft, Sex, and the Crisis of Belief. Chicago and London: The Chicago University Press.

Stephens, Walter. 2016. Skepticism, Empiricism, and Proof in Gianfrancesco Pico della Mirandola's Strix. Magic, Ritual, and Witchcraft 11: 6-29. [CrossRef] 
Stolarski, Piotr. 2011. Dominican-Jesuit Rivalry and the Politics of Catholic Renewal in Poland 1564-1648. Journal of Ecclesiastical History 62: 255-72. [CrossRef]

Tausiet, María. 2013. Urban Magic in Early Modern Spain. Abracadabra Omnipotens. Basingstoke: Palgrave Macmillan.

Thibodeaux, Jennifer D., ed. 2010. Negotiating Clerical Identities. Priests, Monks and Masculinity in the Middle Ages. Basingstoke: Palgrave Macmillian.

Tronu, Carla. 2015. The Rivalry between the Society of Jesus and the Mendicant Orders in Early Modern Nagasaki. Agora: Journal of International Center for Regional Studies 12: 25-39.

Tschacher, Werner. 2000. Der Formicarius des Johannes Nider von 1437/38. Studien zu den Anfängen der europäischen Hexenverfolgungen im Spätmittelalter. Aachen: Shaker Verlag.

Tschaikner, Manfred. 2010. „Mordio! Fürio! Helfio“—Die Hexenpredigten des Feldkircher Kapuzinerguardians, der gescheiterte Hexenprozess von Bregenz und das "Wunder von Bürs" (1629/30). Montfort. Zeitschrift für Geschichts Vorarlbergs 63: 109-24.

Utz Tremp, Kathrin. 2008. Von der Häresie zur Hexerei. „Wirkliche” unnd imaginäre Sekten im Spätmittelalter. Hannover: Hahnsche Buchhandlung.

Veenstra, Jan. R. 1998. Magic and Divination at the Courts of Burgundy and France. Text and Context of Laurens Pignon's 'Contre les devineus' (1411). Leiden, New York and Köln: Brill.

Voltmer, Rita. 2001. Zwischen Herrschaftskrise, Wirtschaftsdepression und Jesuitenpropaganda. Hexenverfolgungen in der Stadt Trier (15.-17. Jahrhundert). Jahrbuch für westdeutsche Landesgeschichte 27: 37-107.

Voltmer, Rita. 2003. “Germany's First, Superhunt?"-Rezeption und Konstruktion der so genannten Trierer Verfolgungen (16.-21. Jahrhundert). In Realität und Mythos. Hexenverfolgung und Rezeptionsgeschichte. Edited by Katrin Moeller and Burghart Schmidt. Hamburg: DOBU Verlag, pp. 225-58.

Voltmer, Rita. 2006. Jesuits (Society of Jesus). In The Encyclopedia of Witchcraft. The Western Tradition. Edited by Richard M. Golden. St. Barbara: ABC Clio, pp. 586-89.

Voltmer, Rita. 2009. Witch-finders, witch-hunters or kings of the sabbath? The prominent role of men in the mass persecutions of the Rhine-Meuse area (16th-17th centuries). In Witchcraft and Masculinities in the Early Modern World. Edited by Alison Rowlands. Basingstoke: Palgrave Macmillan, pp. 74-99.

Voltmer, Rita. 2010a. Klerikaler Antiklerikalismus? Die Kritik am geistlichen Stand bei Johannes Geiler von Kaysersberg (1445-1519). In Kirchlicher und religiöser Alltag im Spätmittelalter. Edited by Andreas Meyer. Ostfildern: Jan Thorbeke Verlag, pp. 47-75.

Voltmer, Rita. 2010b. „Hört an neu schrecklich abentheuer/von den unholden ungeheuer"-Zur multimedialen Vermittlung des Fahndungsbildes „Hexerei" im Kontext konfessioneller Polemik. In Repräsentationen von Kriminalität und öffentlicher Sicherheit. Bilder, Vorstellungen und Diskurse vom 16. bis zum 20. Jahrhundert. Edited by Karl Härter, Gerhard Sälter and Eva Wiebel. Frankfurt am Main: Vittorio Klostermann, pp. 89-163.

Voltmer, Rita. 2015. The Judge's lore? The politico-religious concept of metamorphose in the peripheries of Western Europe. In Werewolf Histories. Edited by Willem de Blécourt. Basingstoke: Palgrave Macmillan, pp. 159-84.

Voltmer, Rita. 2016. Jesuiten und Kinderhexen. Thesen zur Entstehung, Rezeption und Verbreitung eines Verfolgungsmusters. In Hexenkinder-Kinderbanden-Straßenkinder. Edited by Wolfgang Behringer and Claudia Opitz-Belakhal. Bielefeld: Verlag für Regionalgeschichte, pp. 201-32.

Voltmer, Rita. 2017a. Wissen, Medien und die Wahrheit. Überlegungen zu Transferprozessen von ,Hexenwissen'. In Hexenwissen. Zum Transfer von Magie- und Zauberei-Imaginationen in interdisziplinärer Perspektive. Edited by Heinz Sieburg, Rita Voltmer and Britta Weimann. Trier: Paulinus Verlag, pp. 3-46.

Voltmer, Rita. 2017b. The Witch Trials. In The Oxford Illustrated History of Witchcraft and Magic. Edited by Owen Davies. Oxford: University Press, pp. 97-133.

Voltmer, Rita. 2018a. Im Namen der Dynastie. Medizin, Astrologie und Magie, Dämonomanie und Exorzismus am jülisch-klevischen Hof (1585-1609). In Herrschaft, Hof und Humanismus. Wilhelm V. von Jülich-Kleve-Berg und seine Zeit. Edited by Guido von Büren, Ralf-Peter Fuchs and Georg Mölich. Bielefeld: Verlag für Regionalgeschichte, pp. 403-38.

Voltmer, Rita. 2018b. Herren und Hexen. Adlige Hexenpolitik in der Nordeifel und in angrenzenden Gebieten. In Herren und Hexen in der Nordeifel. Darstellung-Edition—Vergleiche. Weilerswist: Verlag Ralf Liebe, pp. 3-152. 
Voltmer, Rita. 2018. Witchcraft in the city. Patterns of Persecution in the Holy Roman Empire. In La sorcellerie et la ville. Witchcraft and the City. Edited by Antoine Follain and Maryse Simon. Strasbourg: Presses Universitaires de Strasbourg, pp. 150-74.

Voltmer, Rita. 2020. Hexenbrenner und Hexenbischöfe-Zur (De)Konstruktion eines Verfolgungsparadigmas (16.-21. Jahrhundert). In Ideal und Praxis. Bischöfe und Bischofsamt im Heiligen Römischen Reich 1570-1629. Edited by Peter Walter (†), Wolfgang Weiß and Markus Wriedt. Würzburg: Aschendorff, in print.

Voltmer, Rita, and Karl Weisenstein. 1996. Das Hexenregister des Claudius Musiel. Ein Verzeichnis von hingerichteten und besagten Personen aus dem Trierer Land (1586-1594). Trier: Spee Buchverlag GmbH Trier.

Voltmer, Rita. forthcoming. Demonology and Anti-demonology: Binsfeld's De confessionibus and Loos's De vera et falsa magia. In The Science of Demons. Edited by Jan Machielsen. London: Routledge, in print.

Waite, Gary K. 2003a. Anabaptist Anticlericalism and the Laicization of Sainthood. Anabaptist and Sanctity in the Netherlands. In Confessional Sanctity (c. 1500-c. 1800). Edited by Jürgen Beyer. Mainz: Verlag Philipp von Zabern, pp. 163-80.

Waite, Gary K. 2003b. Heresy, Magic, and Witchcraft in Early Modern Europe. Basingstoke: Palgrave Macmillan.

Waite, Gary K. 2007. Eradicating the Devil's Minions. Anabaptists and Witches in Reformation Europe. Toronto, Buffalo and London: University of Toronto Press.

Waite, Gary K. 2012. Demonizing Rhetoric, Reformation Heretics and the Witch Sabbaths: Anabaptists and Witches in Elite Discourse. In The Devil in Society in Premodern Europe. Edited by Peter J. Dendle and Richard Raiswell. Toronto: Centre for Reformation and Renaissance Studies, pp. 195-219.

Waite, Gary K. 2013. Sixteenth-Century Religious Reform and the Witch-Hunts. In The Oxford Handbook of Witchcraft in Early Modern Europe and Colonial America. Edited by Brian P. Levack. Oxford: Oxford University Press, pp. 485-506.

Walker, Anita M., and Edmund H. Dickerman. 2001. A Notorious Woman: Possession, Witchcraft and Sexuality in Sevententh-Century Provence. Historical Reflections/Reflexions Historiques 27: 1-26.

Warfield, Abaigéal. 2017. Witchcraft Illustrated: The Crime of Witchcraft in Early Modern German News Broadsheets. In Broadsheets. Single-Sheet Publishing in the First Age of Print. Edited by Andrew Pettegree. Leiden and Boston: Brill, pp. 459-87.

Watt, Jeffery R. 2007. The Demons of Carpi: Exorcism, Witchcraft, and the Inquisition in a Seventeenth-Century Convent. Archiv für Reformationsgeschichte. Archive for Reformation History 98: 107-33. [CrossRef]

Watt, Jeffrey R. 2009. The Scourge of Demons. Possession, Lust, and Witchcraft in a Seventeenth-Century Italian Convent. Rochester: University of Rochester Press.

Weber, Hartwig. 1996. 'Von der verführten Kinder Zauberei' Hexenprozesse gegen Kinder im alten Württemberg. Sigmaringen: Jan Thorbecke Verlag.

Worcester, Anti-Jesuit Polemic. The Cambridge Encyclopedia of the Jesuits. Edited by Thomas Worcester SJ. Cambridge: Cambridge University Press, pp. 30-35.

(C) 2019 by the author. Licensee MDPI, Basel, Switzerland. This article is an open access article distributed under the terms and conditions of the Creative Commons Attribution (CC BY) license (http://creativecommons.org/licenses/by/4.0/). 
Article

\title{
The Dissolution of the Monasteries and the Democratisation of Magic in Post-Reformation England
}

\author{
Francis Young \\ Independent Scholar, 8 Tabor Court, Peterborough PE7 8GF, UK; f.k.young.99@cantab.net
}

Received: 18 March 2019; Accepted: 28 March 2019; Published: 31 March 2019

\begin{abstract}
The dissolution of the monasteries in England (1536-1540) forced hundreds of former inmates of religious houses to seek livelihoods outside the cloister to supplement meagre pensions from the crown. Among the marketable skills these individuals possessed were Latin literacy, knowledge of liturgy, sacramental authority and a reputation for arcane learning: all qualities desirable in magical practitioners in early modern Europe. Furthermore, the dissolution dispersed occult texts housed in monastic libraries, while the polemical efforts of the opponents of monasticism resulted in the growth of legends about the magical prowess of monks and friars. The dissolution was a key moment in the democratisation of learned magic in sixteenth-century England, which moved from being an illicit pastime of clerics, monks and friars to a service provided by lay practitioners. This article considers the extent of interest in magic among English monks and friars before the dissolution, the presence of occult texts in monastic libraries, and the evidence for the magical activities of former religious in post-dissolution England. The article considers the processes by which monks, friars and monastic sites became associated with magic in popular tradition, resulting in a lasting stereotyp. of medieval monks and friars as the masters of occult knowledge.
\end{abstract}

Keywords: ritual magic; monasticism; dissolution of the monasteries; English reformation; monks; friars

\section{Introduction}

The libraries of religious houses in medieval England were one of the major depositories for texts of magic (Davies 2009, p. 36) and, while late medieval clerics in general were notorious for their interest in magic, religious men (professed monks and friars) fell under even greater suspicion for involvement in occult practices on account of their greater learning. The dissolution of the monasteries in the years $1536-1540$ brought to an end a culture of monastic occultism and resulted in the dispersal of both magical books and men possessed of magical knowledge (a further smaller dissolution occurred in 1559 when the handful of religious houses re-founded under Mary I were shut down by Elizabeth I). By the second half of the sixteenth century, the clerical magic of the pre-Reformation world had become a largely lay phenomenon and a class of professional service magicians (cunning men and women) was developing.

The 'democratisation of magic', which was accompanied by a growth in lay literacy and the translation of many Latin magical texts into the vernacular, transformed magic from an illicit pursuit of learned clerics into a potential temptation for any literate person and a viable professional career for laypeople. However, the process by which this transformation came about remains obscure. While it is probable that no single explanation suffices for the complex phenomenon of the democratisation of magic in early modern England, this article examines one part of the puzzle, namely, the impact of the dissolution of the monasteries on the diffusion of magical knowledge into non-clerical contexts. 
In his classic study of supernatural belief in early modern England, Religion and the Decline of Magic, Keith Thomas observed that 'the Reformation ... robbed the priest of most of his magical functions', while the clergy lost their 'monopoly of learning', including knowledge of the occult arts. (Thomas 1991, pp. 327-28). It was Thomas who coined the phrase 'democratisation of magic' (Thomas 1991, p. 269), a theme which has since been explored by scholars such as Davies (2009, pp. 61-67), Timbers (2014, pp. 54-59) and Bell (2012, pp. 108-15). Klaassen (2013, pp. 174-78; 2018, p. 170), while using the alternative terms 'vernacularisation' and 'popularisation', has focussed attention on the same phenomenon. Davies (Davies 2007, p. 172) has argued that 'The void left by the clergy's partial withdrawal from popular magic' after the English Reformation resulted in the proliferation of lay service magicians.

Following the dissolution, ex-monks and ex-friars were assimilated into broader English society as parish clergy, schoolmasters and craftsmen, and those ex-religious who remained loyal to the papacy enjoyed enhanced prestige during the reign of Mary I (1553-1558), when there were also limited revivals of monasticism. Many former religious lived on into the latter decades of the sixteenth century, and even into the reign of James I. As Thomas observed, 'the association in the popular mind between magic and the priesthood was only slowly eradicated' (Thomas 1991, p. 328); this was not only because memories lingered but also because it took many decades for the old Catholic clergy to die out. By the time the last pre-Reformation religious expired, they had already, in some cases, passed the baton of monasticism to a younger generation of missionary clergy, such as the aged monk of Westminster, Sigebert Buckley, who clothed two young men in the English Benedictine habit in 1607 (Lunn 1980, pp. 92-95).

There is a danger of exaggerating the extent to which the clergy abandoned the field of magic to the laity in sixteenth-century England. Rider (2015, p. 322) has noted that 'common magic' was not always truly common, insofar as it often required a literate person (frequently a cleric) to write charms. Similarly, Davies (Davies 2007, p. 69) acknowledges that the requirement for service magicians to be at least semi-literate explains why cunning men and women tended not to be drawn from the labouring class, but were instead craftsmen, tradesmen or farmers. The transition from clerical to lay dominance of magic may have been a more gradual process than Thomas envisaged. The clergy were a group especially likely to be accused of magic, on account of 'their access to sacred substances and to books' (Rider 2015, p. 324); and just as the belief that Catholic priests were the most effective exorcists persisted in England long after the Reformation (Young 2013, pp. 220-22), so they continued to be associated with magical knowledge.

While some vernacular magical texts were produced in England even before the Reformation, participation in the transmission of illicit magical texts required Latin literacy. This was because no practitioner could be guaranteed to have access to vernacular texts, since after the dissolution magical texts usually circulated secretly and only in manuscript. Furthermore, the practice of ritual magic (sometimes called necromancy), which involved the conjuration of spirits to perform the will of the magician, required knowledge of the liturgy and the ability to adap. liturgical material to illicit purposes. In addition, many texts of ritual magic required the magician to be a priest (or at least a tonsured cleric who had received the minor order of exorcist), or to have access to a priest.

Nevertheless, it was not primarily the technical requirements of ritual magic that made the former members of monastic communities the ideal transmitters and practitioners of magical traditions, but rather the range of interests and climate of intellectual exploration that existed in late medieval monasteries. Monks, friars and canons had the time, facilities and opportunities to experiment with alchemy and astrological image magic, as well as the cultivation of herbs reputed to have magical properties. Furthermore, the size and range of monastic libraries rivalled only those of England's two universities. We should not be surprised, therefore, if former religious took some of their occult knowledge with them after the dissolution and transmitted it to the common magical tradition.

The focus of this article is on male religious, on the grounds that no case has yet come to light of a former nun or other religious woman involved in magic after (or indeed before) the dissolution. 
However, the study of women involved in learned magic is still a field of research in its infancy (Rider 2019, p. 348) and it is possible that previously unnoticed connections between English nuns (and former nuns) and magical practice will be uncovered in years to come.

\section{Magic in the Late Medieval English Monastery}

By no means were all the medieval magical practitioners monks, or even clerics, although the degree of functional Latinity required for engagement with magic meant that they were usually men in minor orders who had received the tonsure (Klaassen 2019, p. 201). However, monks, friars, university masters and students were the four classes of cleric who had the time to experiment with magic, in contrast to the overworked parish clergy (Kieckhefer 1997, pp. 151-56). The size and range of monastic libraries, combined with the high level of education received by monks and friars (a high proportion of late medieval mendicant friars were doctors of theology) meant that they had more opportunities to study (if not practise) learned magic than any other group. Furthermore, as Page (2013, p. 140) has argued, monks came under less scrutiny than masters at universities owing to the pedagogical duties of the latter, meaning that monasteries were the safest place to study and practise magic in medieval England. Furthermore, 'monasteries provided a long-term intellectual context within which group. with common interests could develop. (Klaassen 2013, p. 51), while the turnover of personnel in a university resulted in a less stable environment.

The records of visitations of monasteries by bishops, which were intended to uncover irregularities and abuses, regularly mention instances of monks attempting to use magic or procure magical services, usually in order to find lost items. For instance, a thirteenth-century abbot of Selby, Yorkshire, was found to be spending large sums on consulting a magician in the hop. of recovering the body of his drowned brother for burial. In 1440, the Augustinian abbot of Leicester, William Sadyngton, was accused of using the fingernail of a young boy to divine the future (Page 2013, pp. 26-27). Although Sadyngton's accusers portrayed his activities as unworthy of his monastic profession, the library of Leicester Abbey contained numerous works on natural magic and divination (Page 2013, p. 28).

On the eve of the dissolution, Thomas Sall, the precentor of Norwich Cathedral Priory, kep. several houses to which people resorted for magical help (Maxwell-Stuart 2014, p. 97), and even abbots and priors were known to consult magicians for help in finding lost items (Thomas 1991, p. 324). In a notorious case, William Stapleton, a monk of St Benet's Abbey at Holme, Norfolk, used ritual magic in 1528 in an attemp. to find treasure to pay for a dispensation from his monastic profession (Maxwell-Stuart 2014, pp. 98-100). Archaeological evidence from both St Augustine's, Canterbury, and Glastonbury Abbey suggests that monks were engaged in alchemical experimentation. The Augustinian Bridlington Priory in Yorkshire produced the noted alchemical writer George Ripley (d. 1490). Booth (2017, pp. 195-216) has recently examined in depth the material evidence for alchemical activity in British monasteries.

Monks were also deeply involved in the practice of astrological image magic. In an extensive study of the occult library of St Augustine's, Canterbury, Page has shown that the monks were interested in virtually all forms of natural magic, including those that strayed close to the edge of orthodoxy (such as techniques for the making of magical monsters (Page 2013, pp. 49-72). Astrological image magic could easily veer into practices reminiscent of witchcraft, such as the making of human effigies to exact revenge. A monk of Norwich, William Bockenham, may have been responsible for the transcription of such a rite in the fifteenth century (Cambridge University Library MS Dd.xi.45, fols 134v-9v). On a more mundane level, workshop. at Whitby Abbey seem to have been engaged in the manufacture of occult amulets (Gilchrist 2019, pp. 388, 392), perhap. for sale to pilgrims.

While texts of alchemy, astrology and various kinds of 'natural magic' filled English monastic libraries, texts of ritual magic involving the invocation of spirits were rarer. Page (2013, p. 22) has noted that the monks of St Augustine's, Canterbury, who were fascinated by texts of natural and astrological magic, avoided collecting ritual magic texts. However, St Augustine's provided a congenial environment for studying magic since individual monks were permitted to amass their own personal 
book collections, and Page speculates that monks may have justified their ownership of occult texts on the grounds of their superior spiritual discernment gained through mystical practice. Michael Northgate, one of the major collectors of occult books at St Augustine's, may have seen the monastery 'as a refuge for men who wished to conceal their occult interests'. It is ironic that 'repentant' magicians sometimes entered monasteries to atone for their sins, given that monastic libraries often contained magical texts, and it is even possible that some individuals joined monasteries to learn more about magic (Page 2013, p. 23). Others, however, like a monk of Rievaulx accused of 'nefarious magic spells and incantations' (Rider 2012, pp. 160-61) seem to have felt it necessary to abscond from the monastery in order to practise magic.

The library of the Austin Friars in York, donated to the house by the alchemical writer John Erghome in the 1370s and 1380s, reflected an even broader range of magical interests than the library of St Augustine's. In addition to works of natural magic, Erghome also collected copies of the 'Sworn Book of Honorius', the Ars Notoria and other ritual magic texts explicitly focussed on summoning spirits (Page 2013, p. 29). None of Erghome's occult books survive, but one example of a surviving book in the ritual magic tradition from an English monastic context is British Library MS Royal $12 \mathrm{C}$ 6, a treatise on learning shorthand derived from the Ars Notoria (a text of ritual magic that promised to enhance the memory of the magician and speed up the process of learning). The manuscrip. was produced for the monks of Bury St Edmunds in around 1400 (Haines 2019, p. 379). This suggests that, at the very least, the monks of Bury were seeking magical shortcuts to learning.

The study of magic in the medieval monastery served a multitude of purposes. At one end of the spectrum, some monks and friars effectively pursued careers as service magicians, with several even getting involved in magical scandals at court (Young 2017, pp. 33-35). At the other end of the spectrum, monks and friars collected magical texts solely for research purposes, in order to know what magicians were doing so that they could more thoroughly condemn their activities. Monastic involvement in magic cannot be reduced to a straightforward dichotomy between illicit behaviour and learned condemnation; many monks and friars seem to have found themselves in a hinterland of intellectual and spiritual exploration in which magical texts were accorded some value, even if they were not practising as out-and-out sorcerers. Klaassen (2013, p. 56) has noted that the Ars Notoria was 'frequently collected with works that suggest a deep interest in affective religious devotion', while Fanger (2012, p. 26) suggests that it may be necessary to broaden our understanding of medieval mysticism to embrace certain ritual magic texts that were clearly used in a devotional way. Indeed, Véronèse (2012, pp. 37-78) has questioned whether the Ars Notoria (at least in some versions) ought to be viewed as a magical text at all. John Erghome, the Augustinian friar who donated his occult library to the Austin Friars in York publicly repudiated magic but was involved in diffusing the prophetic and mystical writings of John of Bridlington; perhaps, then, historians of monastic occultism should not be seeking disobedient monks but rather individuals with a complex range of 'magico-religious interests'.

\section{Magic and the Dissolution}

It is ironic that the dissolution which resulted in the dispersal of magical books from monastic libraries and magical knowledge via ex-monks and ex-friars was also, in part, justified by the alleged involvement of religious men in magic. Parish (2015, pp. 411-18) has shown how the anti-monastic propaganda of the Henrician Reformation watered the older suspicion that clerics with too much time on their hands might dabble in the dark arts, which thereby became 'the starting point for a more broadbrush representation of Catholic theology and practice as quasi-magical'. Reformers were thus able to move from the familiar (complaints about corrup. clerics) to a radical rejection of Catholic orthodoxy and sacramental authority.

Identifying the involvement of monks and friars in 'superstitious' activities seems to have been part of the agenda of the commissioners deputed by the Lord Privy Seal, Thomas Cromwell, to dissolve religious houses between 1536 and 1540. In 1536, an informant named Richard Branktre accused William Love, the Cistercian Abbot of Coggeshall in Essex, of the reading of anti-royal prophecies. 
Branktre also claimed to know, from testimony given by John Sampford (a previous abbot) and Nicholas Crane (a servant), that Love had given a drink to a young woman to cause a miscarriage. She nearly died as a result, and the abbot and others made preparations to bury her in the wood yard if she did. The administration of a potion to cause abortion was an instance of veneficium (occult poisoning), a practice closely linked with harmful magic. Branktre also alleged that Abbot Love 'did unlawfully use one Robert Goswill, then young and now a monk there', and claimed that the abbot used magic to find lost objects (Elton 1972, pp. 154-55). Accusations of sodomy were often linked with magic, as in the case of Lord Hungerford, executed for 'treason of buggery' in 1540 (Young 2017, p. 76).

Cromwell's commissioners portrayed the members of monastic communities as dilettantes addicted to excessive curiosity. When they arrived to confiscate the valuables of Walsingham Priory in 1536, the commissioners reported that they found an entire secret alchemical laboratory, with 'nothing there wanting which should belong to the art of multiplying' (Wright 1843, p. 138). Some religious deployed the occult arts in open defiance of the Henrician regime, like the Dominican friar Dr Maydland. An agent of Thomas Cromwell, Jasper Fyloll, reported in 1535 that 'friar Dr Maydland said he would like to see the head of every maintainer of the new learning upon a stake ... and to see the king die a "violent and shameful" death'. Maydland declared that 'he knew by his science of necromancy that the new learning should be suppressed, and the old restored by the king's enemies from beyond the sea' (Brewer et al. 1862-1932, vol. 9, p. 846). This was a reference to the widespread expectation that the Holy Roman Emperor Charles V would invade England and overthrow Henry VIII.

Reformers not only tried to blacken the reputations of living monks and friars, but also sought to reinvent revered monastic figures of the medieval past as necromancers. Parish (2005, pp. 45-70) has shown that monastic figures from the medieval past, such as St Dunstan, were reimagined by polemical writers like John Bale as demonic magicians. Yet the dissolution also had more practical consequences for the transmission of knowledge of magic. Klaassen (2013, p. 185) has suggested that one reason why the copying of texts of astrological image magic tailed off in England in the mid-sixteenth century was the dissolution, because monasteries were the principal location of intellectual exchange about this genre of magic. By contrast, the copying of texts of ritual magic continued unabated because, Klaassen argues, its transmission 'depended on personal connections' rather than the continuity of institutions.

It may be that some genres of magic were such specialist fields of interest that their narrow appeal to a small and dedicated group ensured the survival of manuscripts. As Klaassen (2013, p. 188) has suggested, the Protestant reaction against Scholasticism may have marginalised hitherto popular genres of magic, such as image magic, as intellectually redundant. By contrast, Catholics and Protestants shared the belief in angels and demons that underpinned ritual magic. The mathematician, alchemist and ritual magician John Dee (1527-1608/9) acquired the medieval catalogue of occult books in the library of St Augustine's, Canterbury, and appears to have made strenuous efforts to obtain as many of the books in the catalogue as possible. Dee's marginal annotations survive in many of the still extant books from St Augustine's (Page 2013, pp. 133-40). For individuals with Dee's range of interests, the dissolution was a potential windfall of otherwise unobtainable books, and Dee's attitude to the dissolution will be explored further below. However, Dee was an elite figure whose knowledge equalled (and probably exceeded) that of the medieval monks whose works on magic he craved, and we can learn little about the democratisation of magic from Dee's book collecting habits. The extent to which magical texts from monastic libraries found their way into the hands of less learned lay service magicians remains unknown.

\section{Monks and Friars as Magicians in Post-Reformation England}

A handful of former monks and friars can be identified with certainty as practitioners of magic after the dissolution, but it is likely there were many more. William Blomfild (fl. 1529-1574), a former monk of Bury St Edmunds, is one example whose career is better documented than most. Born in Bury, Blomfild seems to have entered the abbey in the town at an early age. He may have been a kinsman of the alchemist and cunning man Myles Blomefylde (1525-1603) and first appears in the 
historical record in 1529, when William Blomfild was questioned in London about holding Protestant views (Principe 2004, pp. 265-66). This occurred in the wake of the scandal caused by another Bury monk, Richard Bayfield, who abandoned his monastic vocation in order to flee abroad and become a supplier of Protestant books to England. Bayfield was apprehended and burnt as a heretic in 1531 (Young 2016, pp. 120-21). Blomfild abjured the heresies of which he was accused, but the fact that Blomfild does not appear among the records of those monks pensioned off after the dissolution of the abbey on 4 November 1539 (Blackwood 2001, pp. 310-11), makes it probable that he, too, had already abandoned his monastic vocation by that point and was no longer living at Bury.

On 29 July 1546 Blomfild's servant John Morvill accused him of practising necromancy:

Upon [Morvill's] promise of secrecy, Blomefyld prepared to make a circle that night, which the two of them should sit in (making it in the leads if the weather held up. but in the chamber if it rained). [Morvill] ran to Blomefyld's house and fetched his book 'to set the weather'. 'Then,' said Blomefyld, 'the worst is I shall needs destroy part of the house here'. 'Sir,' quoth John, 'what will you do with this little child here?' 'Mar[r]y!' saith he, 'I would that he were away. And so I carried [the child] to Father Beste's house. And when I came again I did promise him as I did before; and whiles all things were a preparing to be done, Mr. Secretary Pagget came in unto him, and so prevented the matter. (Brewer et al. 1862-1932, vol. 21, no. 1, pp. 667-68)

It is unclear, from this fragmentary account, why Blomfild was making a circle, but the domestic context suggests that he may have been engaged in treasure hunting (which often happened in houses). Blomfild intended initially to perform the operation on the building's lead-covered roof ('in the leads'). Blomfild's reported concern with controlling the weather may have been linked to his desire to draw a magic circle on the roof of a building; alternatively, necromantic rituals were often thought to cause storms, and Blomfild's instructions to his servant to fetch a book of weather magic may have been to protect against this. Blomfild's fear that the building in question might be damaged in a magical operation, and that a child inside might be harmed, may be linked to a belief that evil spirits often caused damage and harm when summoned. 'Secretary Pagget' was William Paget (1506-1563), who was Secretary of State from 1543. Paget's appearance probably places the action in London. His servant's accusation of necromancy does not seem to have damaged Blomfild's reputation and, in 1569, he was appointed vicar of St Simon and St Jude, Norwich. Blomfild was not a popular vicar; but his problems derived not from accusations of practising magic but from his strident Puritan religious views. Blomfild's later reputation rests on his tracts and poems on alchemy.

While Blomfild favoured the Puritan cause after his departure from monastic life, another former monk who dabbled in magic identified with persecuted English Catholics. John Coxe (alias Devon) was apprehended by customs officials on 14 April, 1561, at the port of Gravesend while trying to find a ship that would take him to the Spanish Netherlands. When John Coxe was searched, he was found to be carrying letters to Catholic exiles living in the Low Countries. Hauled before a local magistrate in Kent, John Coxe was questioned and admitted to saying mass contrary to the Act of Uniformity and believing that the new religion of England was not the true religion; he revealed that many prominent Essex families, including some of Elizabeth's Privy Councillors, supported a network of 'massing priests' in the countryside. John Coxe confessed to saying mass at the home of Leonard Bilson, a former prebendary of Winchester, 'for hallowing of certain conjurations to those of the said Bilson who practised by those means to obtain the love of my Lady Cotton, the late wife of Sir Richard Cotton, Knight' (Jones 1998, p. 192), or as another source put it, 'Bilson ... to have his will of the Lady Cotton caused young Coxe a priest to say a mass to call on the devil to make her his lady' (British Library MS Add. 48023, fol. 354v).

John Coxe's reported youth, along with the fact that he was a monk, means that he can hardly have been a surviving monk of the first dissolution of the monasteries. It is probable, then, that Coxe was a former monk of the briefly re-founded Westminster Abbey (1556-1559), although Coxe is not mentioned among the monks pensioned off after Westminster's second dissolution (Young 2017, 
pp. 95-96). As a result of the arrest of John Coxe, the authorities raided the homes of Sir Edward Waldegrave at Borley and Sir Thomas Wharton at Beaulieu, both in Essex, which led to the arrests of four clergymen for suspected involvement in a magical plot against Queen Elizabeth. One of these, John Ramridge, was also a former monk of Westminster (Knighton 2006, pp. 117-18). Peter Maxwell-Stuart's $(2014,415 \mathrm{n} 30)$ assertion that another of the magical practitioners convicted as part of the crackdown on magicians in 1561, Francis Coxe, was also a former monk seems to be an error based on confusion with John Coxe. Francis Coxe went on to publish a lengthy confession of his life in magic, but gave no hint of his earlier life.

It is possible that 'friar Bacon', mentioned as the giver of 'help and counsel' to a group of six clerks who attempted a conjuration to discover treasure recorded in Folger MS V.b.26 was a living English friar rather than the historical Roger Bacon (Harms et al., p. 505). The Folger manuscrip. dates to the 1570s, when a number of Franciscan friars from the Greenwich friary dissolved in 1559 were still alive and ministering to exiled English Catholics in the Low Countries (which is the context in which this manuscrip. or ritual magic seems to have originated). However, 'friar Bacon's' help and counsel may be no more than an allusion to the use of a book attributed to Roger Bacon. In contrast to their monastic forebears, there is no sign that monks and friars of the revived English exiled religious houses on the Continent became involved in occult practices. This is scarcely surprising in light of Counter-Reformation anxiety to prove the Reformers wrong about the quality and piety of monastic life.

Hints of monastic influence may be detectable in some surviving manuscripts of magic, such as Cambridge University MS Add. 3544 (the 'Cambridge Book of Magic'), a text of ritual magic composed at some point between 1532 and 1559. An immediate post-dissolution context for the composition of this manuscrip. is suggested by the date range within which it was compiled, the reuse of a vellum leaf from a late medieval gradual as a cover for the paper manuscript, and the content of the text (Foreman 2015, pp. xiv-xvi). The vellum leaf (now Cambridge University Library MS Add. 4435(17)) contains a four-line plainchant for the Conversion of St Paul (25 January) which does not belong to the Sarum rite (the standard liturgy of the medieval English church), opening up the possibility that the manuscrip. originated in a religious house where an alternative usage was maintained (Foreman 2015, pp. $\mathrm{xv}-\mathrm{xvi}$ ).

In and of itself, the reuse of a piece of medieval vellum to cover the Cambridge Book of Magic is merely an indication that the text was written after the start of the dissolution, when scrap. of this kind became widely available to scribes and bookbinders. However, it is clear from the content of the Cambridge Book of Magic that its compiler (who may have been called Paul Foreman) was literate in Latin and liturgically skilled; yet he was not a priest. It is highly unlikely that a layman or secular minor cleric would have possessed the requisite skill set to write MS Add. 3544, which means that it was probably composed by a man trained within a monastic or academic context. Finally, the author's deep knowledge of herbalism and attempts to blend it with ritual magic, including an elaborate rite in which the magician 'marries' the herb valerian (Foreman 2015, pp. 74-79), points to a former monk of friar. Monasteries were renowned for their herb gardens and religious men for their herbal knowledge.

One possible interpretation of the Cambridge Book of Magic is that it was written by an ex-monk or ex-friar using skills learnt within the monastery to practise as a professional service magician (Foreman 2015, pp. xvii-xviii). However, the Cambridge Book draws on both Latin and vernacular sources and contains clear instructions as if it were written for the benefit of a disciple (Foreman 2015, p. vii). It is a practical text, containing a combination of simple 'recipes' and complex 'speculative' spirit conjurations, and represents a point of transition from the clerical magic of the Middle Ages to the vernacularised practice of service magicians lambasted by Reginald Scot in his Discoverie of Witchcraft (1584). If the Cambridge Book of Magic was compiled by a former religious, it is evidence of the involvement of such men in the democratisation of magic. 


\section{A Magical Reputation: Monks and Friars as Stereotyped Magicians}

Whether or not former monks and friars really were a major part of the community of magical practitioners in post-dissolution England, monks and friars were certainly magicians in the popular imagination. Davies (2009, p. 37) has drawn attention to the phenomenon of clerics who wrote on the subject of magic (even when they denounced it) becoming magicians in the popular imagination over time. The thirteenth-century theologians Michael Scot (1175-c. 1232) and Roger Bacon (c. 1214-1294) are perhap. the best-known British victims of this trend before the Reformation. The efforts of polemicists like John Bale to portray pre-Reformation churchmen as necromancers, mentioned above, created an ideal environment for the reinforcement and perpetuation of stereotypes of the monastic conjurer. Robert Greene's play The Honorable Historie of Frier Bacon and Frier Bongay (c. 1589) is perhap. the best-known example of a popular portrayal of Franciscan friars as duelling wizards (Greene 1963, pp. 53-59).

The reputation of Franciscan friars for involvement in magic was not altogether undeserved. Franciscan theology emphasised the importance of intellectual curiosity and of studying the entirety of nature without restriction (Boureau 2006, pp. 111-18), and medieval Franciscans pioneered alchemy. One of the most popular stories of sorcery in medieval England concerned a magical talking bronze head supposedly made by the Franciscan Roger Bacon (Davies 2009, pp. 37-38). Franciscans adopted a materialistic approach to the spiritual world that sometimes led them to promote devotional practices close to or indistinguishable from magic. However, balancing the cultural portrayal of historic friars such as Roger Bacon as magicians, Protestant propagandists tended to portray living Catholic clergy not as wicked necromancers but as frauds intent on faking supernatural feats (Young 2013, p. 147).

One post-Reformation rumour that persistently circulated about monks and friars, and which inspired many treasure hunters, was that they were successful alchemists who had hidden their fabulous wealth somewhere in the ruins of their monasteries (Dillinger 2012, pp. 24-25). In October 1574 , in a letter about his ongoing search for hidden treasure, John Dee asked permission of Lord Burghley to consult manuscripts in an old chapel at Wigmore Castle in Herefordshire, which had belonged to one of the abbots of the Augustinian Wigmore Abbey, 'which had lain there rotting and tossed about unregarded' (Strype 1709, vol. 2, p. 354). Although Dee declared that his interest in the Wigmore manuscripts was genealogical, the appearance of this request to study the papers of the abbot of Wigmore in a letter asking for permission to search for treasure suggests that Dee may have been interested in the manuscripts because he thought they would reveal the location of hidden treasure.

Dee was not alone in his treasure hunting ambitions. Although the early antiquaries who sought to save and recover what they could of the great monastic libraries declared their interest to be purely academic, even the Humanist scholar and royal librarian John Leland (c. 1503-1552) recorded a local Somerset rhyme that was supposed to identify the location of buried treasure (Dillinger 2012, p. 22). Rumours continued to circulate into the seventeenth century. The astral magician Elias Ashmole (1617-1692) heard from Richard Wakeman, town clerk of Bath, about a mysterious 'Red Tincture' that was supposedly found in the walls of Bath Abbey after the dissolution (Ashmole 1966, vol. 2, p. 588). Ashmole's hop. was that this 'tincture' was the philosophers' stone, discovered by the monks and hidden in a wall for safekeeping. Rumours about alchemical treasure were not the only occult associations with monks and friars in post-Reformation England, and a widespread folk-belief that all Benedictine monks were skilled herbalists seems to have persisted in Protestant England well into the eighteenth century. So powerful was this belief that it enabled a number of missionary Benedictine monks to make a living as unlicensed physicians (Young 2013, p. 71).

\section{Conclusions}

The dissolution of the English monasteries resulted in the diffusion of occult knowledge that had hitherto been largely the preserve of monks and friars into a vernacular and common tradition. It has been the aim of this article to shed some light on how this occurred. With the exception of isolated figures such as William Blomfild and John Coxe, the personal presence of former monks and friars in the world of learned and unlearned service magic in post-Reformation England is rather elusive, 
although it is highly likely that other monastic personnel whose identities are now lost to us joined the ranks of service magicians. The Cambridge Book of Magic, a manuscrip. of ritual magic produced at the time of the dissolution or shortly thereafter, shows signs of having been compiled by someone who was probably trained in a monastic context, and who subsequently worked as a service magician.

There can be no doubt about the significance of the indirect contribution of the monasteries to the democratisation of magical knowledge in Elizabethan England. Throughout the medieval and early modern periods, condemnations of magic frequently acted as advertisements for it, and the anti-magical polemic of reformers drew attention to the purported magical skill of men who were about to be cast on their own resources. The propaganda of the Reformation was responsible for creating a stereotyp. of monks and friars as learned in the magical arts, a perception which led individuals such as John Dee to value highly occult manuscripts recovered from dissolved monasteries. Although there is little sign that the post-Reformation monks and friars trained in missionary houses in Continental Europ. continued to pursue the occult interests of their forebears, the works produced within the context of adventurous intellectual communities in medieval monasteries generally found a ready audience among literate laypeople in the later sixteenth century. In this way, medieval monks' communal quest for magical enlightenment lived on in new ways, albeit no longer restricted to a small clerical elite.

Funding: This research received no external funding.

Conflicts of Interest: The author declares no conflict of interest.

\section{References}

Ashmole, Elias. 1966. Elias Ashmole: His Autobiographical and Historical Notes, His Correspondence, and Other Contemporary Sources Relating to his Life and Work, Vol. 2: Texts 1617-1660. Edited by Kurt Josten. Oxford: Clarendon. ISBN 9780199670260.

Bell, Karl. 2012. The Magical Imagination: Magic and Modernity in Urban England 1780-1914. Cambridge: Cambridge University Press. ISBN 9781107002005.

Blackwood, B. Gordon. 2001. Tudor and Stuart Suffolk. London: Carnegie. ISBN 1859360785.

Booth, Christopher. 2017. Holy Alchemists, Metallurgists, and Pharmacists: The Material Evidence for British Monastic Chemistry. Journal of Medieval Monastic Studies 6: 195-215. [CrossRef]

Boureau, Alain. 2006. Satan the Heretic: The Birth of Demonology in the Medieval West. Translated by Teresa Lavender Fagan. Chicago: University of Chicago Press. ISBN 9780226067483.

Brewer, John, James Gairdner, and Robert Brodie, eds. 1862-1932. Letters and Papers, Foreign and Domestic, of the Reign of Henry VIII. 21 vols. London: Various Publishers.

Davies, Owen. 2007. Popular Magic: Cunning-folk in English History. London: Continuum. First published 2003. ISBN 9781847250360.

Davies, Owen. 2009. Grimoires: A History of Magic Books. Oxford: Oxford University Press. ISBN 9780199590049.

Dillinger, Johannes. 2012. Magical Treasure Hunting in Europ. and North America: A History. Basingstoke: Palgrave MacMillan. ISBN 978-0-230-35331-2.

Elton, Geoffrey. 1972. Policy and Police: The Enforcement of the Reformation in the Age of Thomas Cromwell. Cambridge: Cambridge University Press. ISBN 9780521083836.

Fanger, Claire. 2012. Introduction; Theurgy, Magic, and Mysticism. In Invoking Angels: Theurgic Ideas and Practices, Thirteenth to Sixteenth Centuries. Edited by Claire Fanger. University Park: Pennsylvania State University Press, pp. 1-33. ISBN 9780271051420.

Foreman, Paul. 2015. The Cambridge Book of Magic: A Tudor Necromancer's Manual. Edited by Francis Young. Cambridge: Texts in Early Modern Magic. ISBN 9780992640422.

Gilchrist, Roberta. 2019. Magic and Archaeology: Ritual Residues and 'Odd' Deposits. In The Routledge History of Medieval Magic. Edited by Sophie Page and Catherine Rider. London: Routledge, pp. 383-400. ISBN 9781472447302.

Greene, Robert. 1963. Friar Bacon and Friar Bungay. Edited by Daniel Seltzer. Lincoln: University of Nebraska Press. ISBN 978-0803252622. 
Haines, John. 2019. Music. In The Routledge History of Medieval Magic. Edited by Sophie Page and Catherine Rider. London: Routledge, pp. 371-81. ISBN 9781472447302.

Harms, Daniel, James R. Clark, and Josep. H. Peterson, eds. The Book of Oberon: A Sourcebook of Elizabethan Magic. Woodbury: Llewellyn. ISBN 9780738743349.

Jones, Norman. 1998. Defining Superstitions: Treasonous Catholics and the Act against Witchcraft of 1563. In State, Sovereigns and Society in Early Modern England: Essays in Honour of A. J. Slavin. Edited by Charles Carlton. Stroud: St Martin's Press, pp. 187-204. ISBN 9780312210458.

Kieckhefer, Richard. 1997. Forbidden Rites: A Necromancer's Manual of the Fifteenth Century. Stroud: Sutton. ISBN 9780750913799.

Klaassen, Frank. 2013. The Transformations of Magic: Illicit Learned Magic in the Later Middle Ages and Renaissance. University Park: Pennsylvania State University Press. ISBN 9780271056272.

Klaassen, Frank. 2018. Curious companions: Spirit conjuring and alchemy in the sixteenth century. In Knowing Demons, Knowing Spirits in the Early Modern Period. Edited by Michelle D. Brock, Richard Raiswell and David R. Winter. Basingstoke: Palgrave MacMillan, pp. 145-70. ISBN 9783319757377.

Klaassen, Frank. 2019. Necromancy. In The Routledge History of Medieval Magic. Edited by Sophie Page and Catherine Rider. London: Routledge, pp. 201-11. ISBN 9781472447302.

Knighton, C. S. 2006. Westminster Abbey Restored. In The Church of Mary Tudor. Edited by Eamon Duffy and David Loades. Farnham: Ashgate, pp. 77-123. ISBN 978-754630708.

Lunn, David. 1980. The English Benedictines, 1540-1688: From Reformation to Revolution. London: Burnes and Oates. ISBN 9780064944113.

Maxwell-Stuart, Peter. 2014. The British Witch: A Biography. Stroud: Amberley. ISBN 9781445622026.

Page, Sophie. 2013. Magic in the Cloister: Pious Motives, Illicit Interests, and Occult Approaches to the Medieval Universe. University Park: Pennsylvania State University Press. ISBN 9780271060347.

Parish, Helen. 2005. Monks, Miracles and Magic: Reformation Representations of the Medieval Church. London: Routledge. ISBN 9780415316880.

Parish, Helen. 2015. Magic and Priestcraft: Reformers and Reformation. In The Cambridge History of Magic and Witchcraft in the West, Antiquity to the Present. Edited by Daniel J. Collins. Cambridge: Cambridge University Press, pp. 393-425. ISBN 9780521194181.

Principe, Lawrence M. 2004. Blomfild [Blomefield], William (fl. 1529-1574). In The Oxford Dictionary of National Biography. Oxford: Oxford University Press, vol. 6, pp. 265-66. [CrossRef]

Rider, Catherine. 2012. Magic and Religion in Medieval England. London: Reaktion. ISBN 9781780230351.

Rider, Catherine. 2015. Common Magic. In The Cambridge History of Magic and Witchcraft in the West, Antiquity to the Present. Edited by Daniel J. Collins. Cambridge: Cambridge University Press, pp. 303-31. ISBN 9780521194181.

Rider, Catherine. 2019. Magic and Gender. In The Routledge History of Medieval Magic. Edited by Sophie Page and Catherine Rider. London: Routledge, pp. 343-54. ISBN 9781472447302.

Strype, John. 1709. Annals of the Reformation and Establishment of Religion. 2 vols. London: John Wyat.

Thomas, Keith. 1991. Religion and the Decline of Magic. London: Penguin. First published 1971. ISBN 9780140137446.

Timbers, Frances. 2014. Magic and Masculinity: Ritual Magic and Gender in the Early Modern Era. London: I. B. Tauris. ISBN 9781780765594.

Véronèse, Julien. 2012. Magic, Theurgy, and Spirituality in the Medieval Ritual of the Ars notoria. In Invoking Angels: Theurgic Ideas and Practices, Thirteenth to Sixteenth Centuries. Edited by Claire Fanger. University Park: Pennsylvania State University Press, pp. 37-78. ISBN 9780271051420.

Wright, Thomas, ed. 1843. Three Chapters of Letters Relating to the Suppression of the Monasteries. London: Camden Society.

Young, Francis. 2013. English Catholics and the Supernatural, 1553-1829. Farnham: Ashgate. ISBN 9781409455653.

Young, Francis. 2016. The Abbey of Bury St Edmunds: History, Legacy and Discovery. Norwich: Lasse Press. ISBN 9780993306945.

Young, Francis. 2017. Magic as a Political Crime in Medieval and Early Modern England: A History of Sorcery and Treason. London: I. B. Tauris. ISBN 9781788310215.

(C) 2019 by the author. Licensee MDPI, Basel, Switzerland. This article is an open access article distributed under the terms and conditions of the Creative Commons Attribution (CC BY) license (http://creativecommons.org/licenses/by/4.0/). 
MDPI

St. Alban-Anlage 66

4052 Basel

Switzerland

Tel. +41616837734

Fax +41 613028918

www.mdpi.com

Religions Editorial Office

E-mail: religions@mdpi.com www.mdpi.com/journal/religions

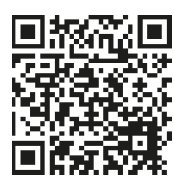



MDPI

St. Alban-Anlage 66

4052 Basel

Switzerland

Tel: +41 616837734

Fax: +41 613028918

www.mdpi.com 